Dissertação apresentada junto à Faculdade de Arquitetura e Urbanismo da Universidade de São Paulo para obtenção do grau de Mestre na área de concentração de Projeto, Espaço e Cultura sob orientaçãoda Profa. Dra. Fernanda Fernades da Silva

\title{
Revista Habitat: \\ um olhar moderno sobre os anos 50 em São Paulo
}

Fabiana Terenzi Stuchi

FAUUSP 2006 
AUTORIZO A REPRODUCÃO E DIVULGACÃO TOTAL OU PARCIAL DESTE TRABALHO, POR QUALQUER MEIO CONVENCIONAL OU ELETRONNICO, PARA FINS DE ESTUDO E PESQUISA, DESDE QUE CITADA A FONTE.

ASSINATURA:

E-MAIL:

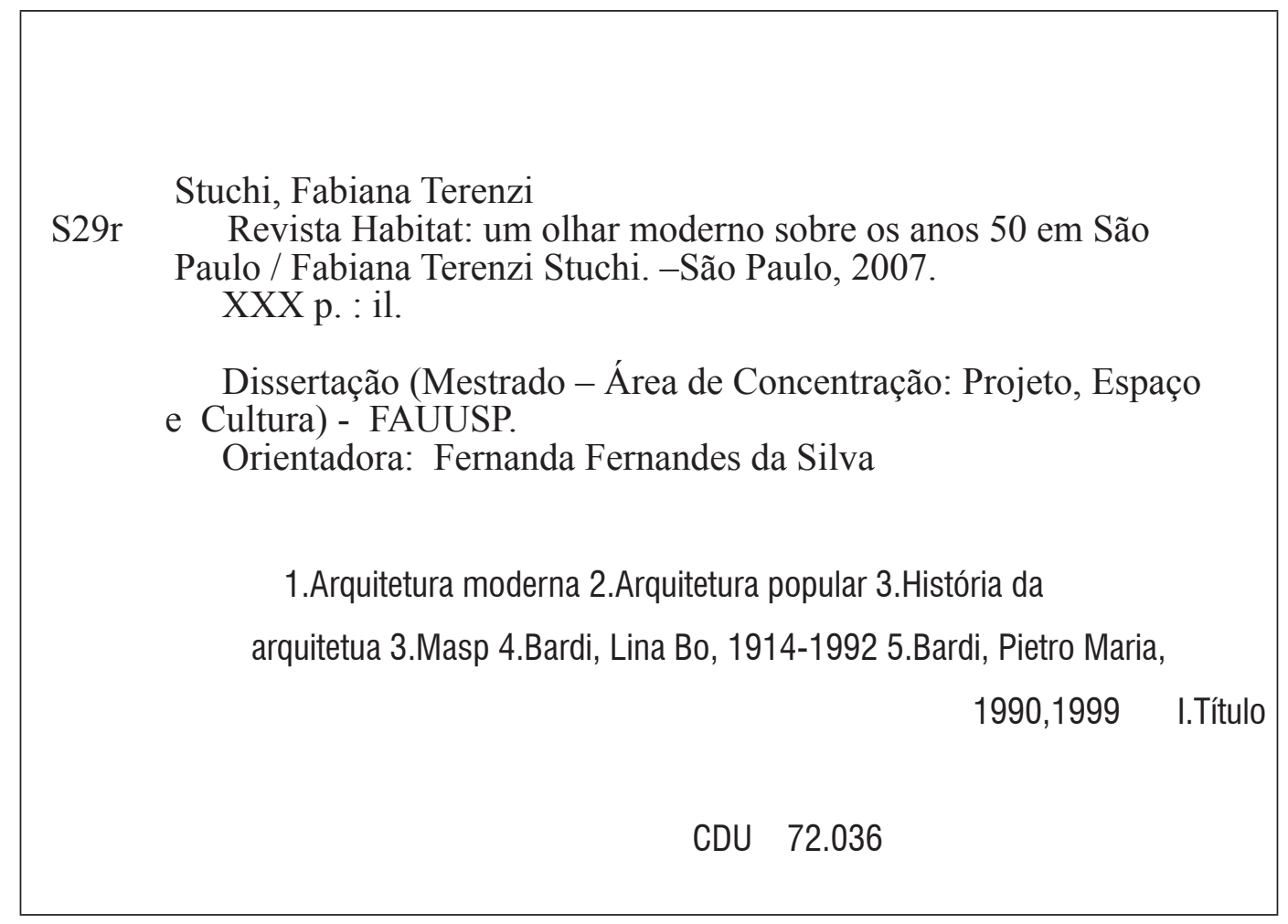


Aos meus pais. 


\section{Agradecimentos}

A professora Fernanda Fernandes da Silva, orientadora no sentido pleno da palavra, agradeço a descoberta da revista Habitat, apresentada por ela em 1997 quando participei, sob sua orientação, como pesquisadora de iniciação científica do projeto integrado de pesquisa "Arquitetura Moderna no Brasil, anos 50/60: a questão da síntese das artes". Anos depois, o reencontro e a indicação de que, novamente, Habitat poderia ser uma "janela" para investigar o período de amadurecimento da arquitetura moderna em São Paulo. Agradeço a dedicação, as leituras minuciosas, o rigor dos comentários e, sobretudo o carinho e o envolvimento com que acompanhou este trabalho.

Aos professores Ana Lanna e Miguel Antonio Buzzar, pelos comentários fundamentais no exame de qualificação, que possibilitou a reorientação a tempo de não nos perdemos numa infinidade de caminhos sedutores.

A Fundação de Amparo à Pesquisa do Estado de São Paulo (FAPESP), pelo apoio financeiro e pelas condições especiais que tornaram possível o desenvolvimento dessa pesquisa.

Minha gratidão ao professor Flávio Motta, pelo privilégio da tarde em que com atenção me recebeu e concedeu uma entrevista recheada de recordações e emoções. Agradeço as Bibliotecas do MASP, do Instituto Pietro Maria Bardi e Lina Bo Bardi pelo acesso a documentos importantes para o trabalho.

A Maria José e Stelita, pela atenção e cuidado com que sempre me orientaram nas buscas pelas estantes da Biblioteca da FAU Maranhão. Aos professores e funcionários da FAUUSP e da secretaria da pós-graduação.

A meus colegas da pós-graduação, que dividiram as conquistas e as aflições deste projeto "coletivo". A José Armênio, Renata, Marcos e João Paulo, pelas condições excepcionais proporcionadas e pela confiança que depositaram em mim.

As pessoas que me derem mais que apoio intelectual. Marina, amiga do coração, que me ouve nos períodos em que fico monotemática. A André, Gabi, Nilce, Juliano, Gustavo, Julie, Davi, Carol e Paula e muitos outros que fazem real a experiência insubstituível da amizade.

Por fim, a minha querida e amada família, minha imensa gratidão. A meus pais, Aderbal e Maria Angela, pela doação, ensinamento, e especialmente pela paciência e cuidado. A meus avós pelo exemplo de correção. Aos meus irmãos, Daniela, pela cumplicidade e equilíbrio único na família, e Eduardo, pelo companheirismo e carinho; sem seu bom humor e atenção, muitos problemas não teriam sido resolvidos. 


\section{Resumo}

A pesquisa analisa os primeiros quinze números da revista Habitat: revista das artes no Brasil, no período compreendido entre outubro de 1950 e abril de 1954. Desses quinze números investigamos num primeiro momento as características que a fazem particular entre as demais revistas do período - a decisiva participação de Pietro Maria Bardi e Lina Bo, sua inserção como parte de um projeto cultural moderno, sua ligação com 0 Museu de Arte de São Paulo (MASP), a diversidade de assuntos que aborda, o contexto histórico e a fundamental presença de seus colaboradores. No segundo momento, enfocamos a arquitetura divulgada em Habitat, sua eleição, os valores que pretende propagar e o diálogo com a crítica internacional, que juntos colaboram para a consolidação da arquitetura moderna no país.

\section{Abstract}

The research analyses the first fifteen editions of Habitat magazine: magazine of Brazilian art, in the period between October 1950 and April 1954. Of these fifteen editions, initially we investigated the characteristics that made the magazine so exceptional among all the other magazines of this same period - the crucial input of Pietro Maria Bardi and Lina Bo, the magazine's role as a modern cultural project, it's connection with São Paulo's Art Museum (MASP), the diversity of subjects covered in the magazine, it's historical context and the fundamental participation of it's collaborators.

Secondly, we focused on the architecture shown in Habitat magazine, its selection, the values it expounded and the dialogue it had with international critics, that together, collaborated for the consolidation of modern architecture in the country. 


\section{Lista de llustrações}

\begin{tabular}{|c|c|c|}
\hline Figura 01 & Capa - Habitat no 01 & Pg. 8 \\
\hline Figura 02 & Capa - Habitat n ${ }^{0} 02$ & Pg. 8 \\
\hline Figura 03 & Capa - Habitat n ${ }^{0} 03$ & Pg. 8 \\
\hline Figura 04 & Capa - Habitat n ${ }^{0} 04$ & Pg. 9 \\
\hline Figura 05 & Capa - Habitat n ${ }^{0} 05$ & Pg. 9 \\
\hline Figura 06 & Capa - Habitat n ${ }^{0} 06$ & Pg. 9 \\
\hline Figura 07 & Capa - Habitat nº 07 & Pg. 9 \\
\hline Figura 08 & Capa - Habitat nº 08 & Pg. 10 \\
\hline Figura 09 & Capa - Habitat n ${ }^{0} 09$ & Pg. 10 \\
\hline Figura 10 & Capa - Habitat no 10 & Pg. 10 \\
\hline Figura 11 & Capa - Habitat no 11 & Pg. 10 \\
\hline Figura 12 & Capa - Habitat no 12 & Pg. 12 \\
\hline Figura 13 & Capa - Habitat no 13 & Pg. 12 \\
\hline Figura 14 & Capa - Habitat no 14 & Pg. 12 \\
\hline Figura 15 & Capa - Habitat no 15 & Pg. 12 \\
\hline \multirow[t]{2}{*}{ Figura 16} & "0 acervo da Pinacoteca" & Pg. 15 \\
\hline & Fonte: Habitat n ${ }^{0} 01$ - pg.42-43 & \\
\hline \multirow[t]{2}{*}{ Figura 17} & "A criança no Museu" & Pg. 15 \\
\hline & Fonte: Habitat n ${ }^{0} 01$ - pg.50-51 & \\
\hline \multirow[t]{2}{*}{ Figura 18} & "Sinopse do Museu de Arte" & Pg. 16 \\
\hline & Fonte: Habitat nº 01 - pg.26 & \\
\hline \multirow[t]{2}{*}{ Figura 19} & "Sinopse do Museu de Arte" & Pg. 17 \\
\hline & Fonte: Habitat n ${ }^{0} 01$ - pg.22-23 & \\
\hline \multirow[t]{2}{*}{ Figura 20} & "Sinopse do Museu de Arte" & Pg. 17 \\
\hline & Fonte: Habitat n ${ }^{0} 01$ - pg.24-25 & \\
\hline \multirow[t]{2}{*}{ Figura 21} & "Pinacoteca do Museu de Arte" & Pg. 18 \\
\hline & Fonte: Habitat $n^{0} 02$ - pg.35 & \\
\hline \multirow[t]{2}{*}{ Figura 22} & "Curso de Gravura" & Pg. 18 \\
\hline & Fonte: Habitat nº 02 - pg.77 & \\
\hline \multirow[t]{2}{*}{ Figura 23} & "Móveis novos" & Pg. 21 \\
\hline & Fonte: Habitat nº 01 - pg.54 & \\
\hline \multirow[t]{2}{*}{ Figura 24} & "Móveis novos" & Pg. 21 \\
\hline & Fonte: Habitat n ${ }^{0} 01$ - pg.56-57 & \\
\hline \multirow[t]{2}{*}{ Figura 25} & "Ourivesaria" & Pg. 22 \\
\hline & Fonte: Habitat nº 06 - pg.34-35 & \\
\hline \multirow[t]{2}{*}{ Figura 26} & "Alencastro" & Pg. 23 \\
\hline & Fonte: Habitat $n^{0} 01$ - pg.90 & \\
\hline
\end{tabular}




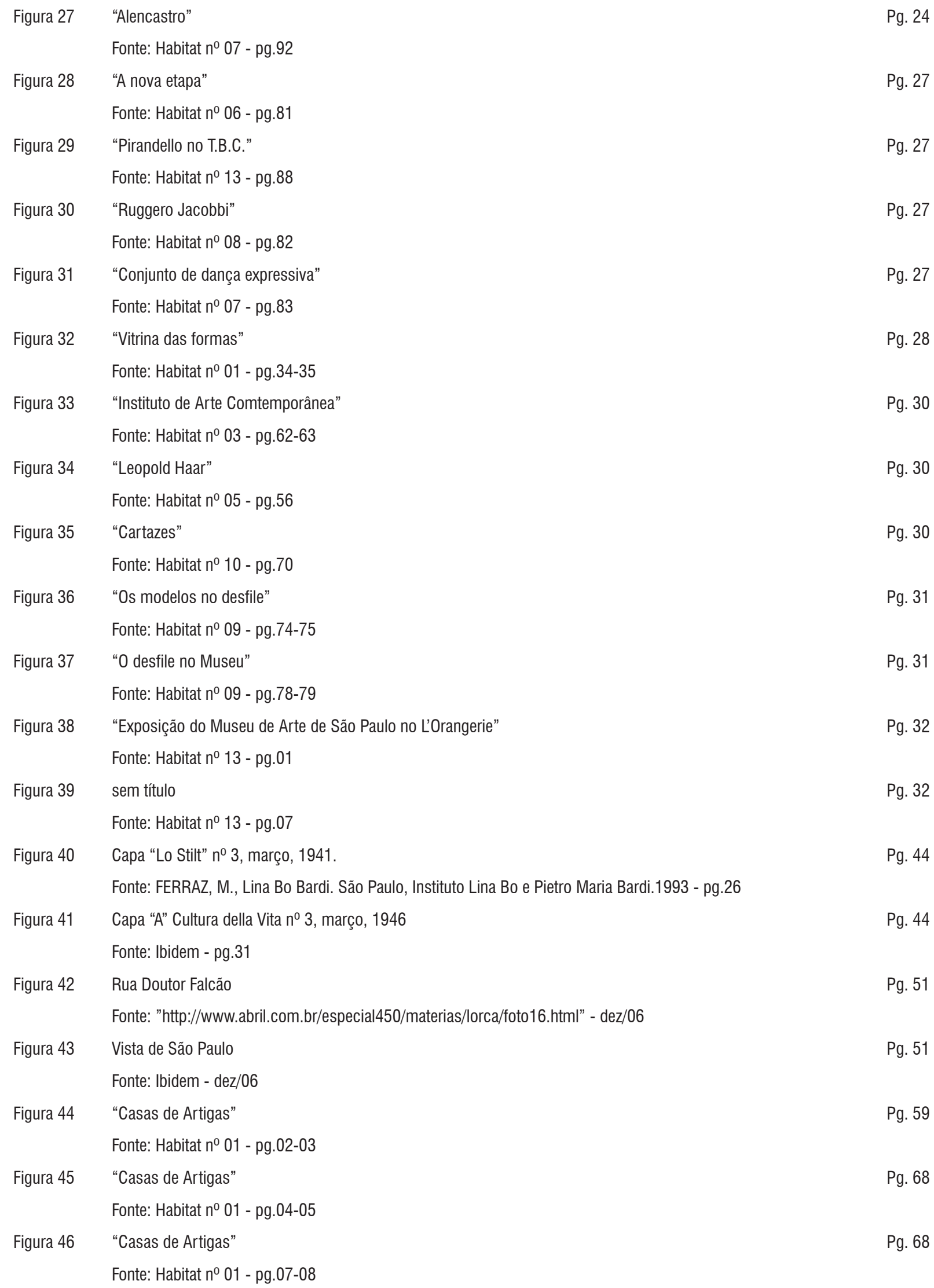




\begin{tabular}{|c|c|c|}
\hline \multirow[t]{2}{*}{ Figura 47} & "Casas de Artigas" & Pg. 68 \\
\hline & Fonte; Habitat n ${ }^{0} 01$ - pg.09-10 & \\
\hline \multirow[t]{2}{*}{ Figura 48} & "Casas de Artigas" & Pg. 68 \\
\hline & Fonte: Habitat n ${ }^{0} 01$ - pg.13-14 & \\
\hline \multirow[t]{2}{*}{ Figura 49} & "Amazonas: o povo arquiteto" & Pg. 71 \\
\hline & Fonte: Habitat n ${ }^{0} 01$ - pg.68-69 & \\
\hline \multirow[t]{2}{*}{ Figura 50} & "Amazonas: o povo arquiteto" & Pg. 71 \\
\hline & Fonte: Habitat n ${ }^{0} 01$ - pg.70-71 & \\
\hline \multirow[t]{2}{*}{ Figura 51} & "Floreal" & Pg. 73 \\
\hline & Fonte: Habitat n ${ }^{0} 12$ - pg.58-59 & \\
\hline \multirow[t]{2}{*}{ Figura 52} & "Corpus do Barroco" & Pg. 73 \\
\hline & Fonte: Habitat n ${ }^{0} 06$ - pg.52-53 & \\
\hline \multirow[t]{2}{*}{ Figura 53} & "Do pequeno ao grande, numa corrida" & Pg. 75 \\
\hline & Fonte: Habitat nº 01 - pg.65 & \\
\hline \multirow[t]{2}{*}{ Figura 54} & "Desenho Industrial” & Pg. 76 \\
\hline & Fonte: Habitat n ${ }^{0} 05$ - pg.62-63 & \\
\hline \multirow[t]{2}{*}{ Figura 55} & "Residência no Morumbi” & Pg. 76 \\
\hline & Fonte: Habitat n ${ }^{0} 10$ - pg.32-35 & \\
\hline \multirow[t]{2}{*}{ Figura 56} & "Alencastro" & Pg. 79 \\
\hline & Fonte: Habitat $n^{0} 01$ - pg.93 & \\
\hline \multirow[t]{2}{*}{ Figura 57} & "Documentos da arte brasileira" & Pg. 79 \\
\hline & Fonte: Habitat $n^{0} 02$ - pg.51 & \\
\hline \multirow[t]{2}{*}{ Figura 58} & "Novo Mundo do Espaço" de Le Corbusier & Pg. 81 \\
\hline & Fonte: Habitat $n^{0} 01$ - pg.36 & \\
\hline \multirow[t]{2}{*}{ Figura 59} & "Novo Mundo do Espaço" de Le Corbusier & Pg. 81 \\
\hline & Fonte: Habitat $n^{0} 01$ - pg.37 & \\
\hline \multirow[t]{2}{*}{ Figura 60} & "As arquiteturas do Convênio Escolar" & Pg. 84 \\
\hline & Fonte: Habitat n0 04 - pg.07 & \\
\hline \multirow[t]{2}{*}{ Figura 61} & "As arquiteturas do Convênio Escolar" & Pg. 84 \\
\hline & Fonte: Habitat $n^{0} 04$ - pg.14 & \\
\hline \multirow[t]{2}{*}{ Figura 62} & "As arquiteturas do Convênio Escolar" & Pg. 84 \\
\hline & Fonte: Habitat $n^{0} 04$ - pg.08 & \\
\hline \multirow[t]{2}{*}{ Figura 63} & "As arquiteturas do Convênio Escolar" & Pg. 84 \\
\hline & Fonte: Habitat $n^{0} 04$ - pg.10 & \\
\hline \multirow[t]{2}{*}{ Figura 64} & "As arquiteturas do Convênio Escolar" & Pg. 84 \\
\hline & Fonte: Habitat n ${ }^{0} 04$ - pg.36 & \\
\hline \multirow[t]{2}{*}{ Figura 65} & "As arquiteturas do Convênio Escolar" & Pg. 84 \\
\hline & Fonte: Habitat n0 04 - pg.18 & \\
\hline \multirow[t]{2}{*}{ Figura 66} & "As arquiteturas do Convênio Escolar" & Pg. 84 \\
\hline & Fonte: Habitat nº 04 - pg.12 & \\
\hline
\end{tabular}




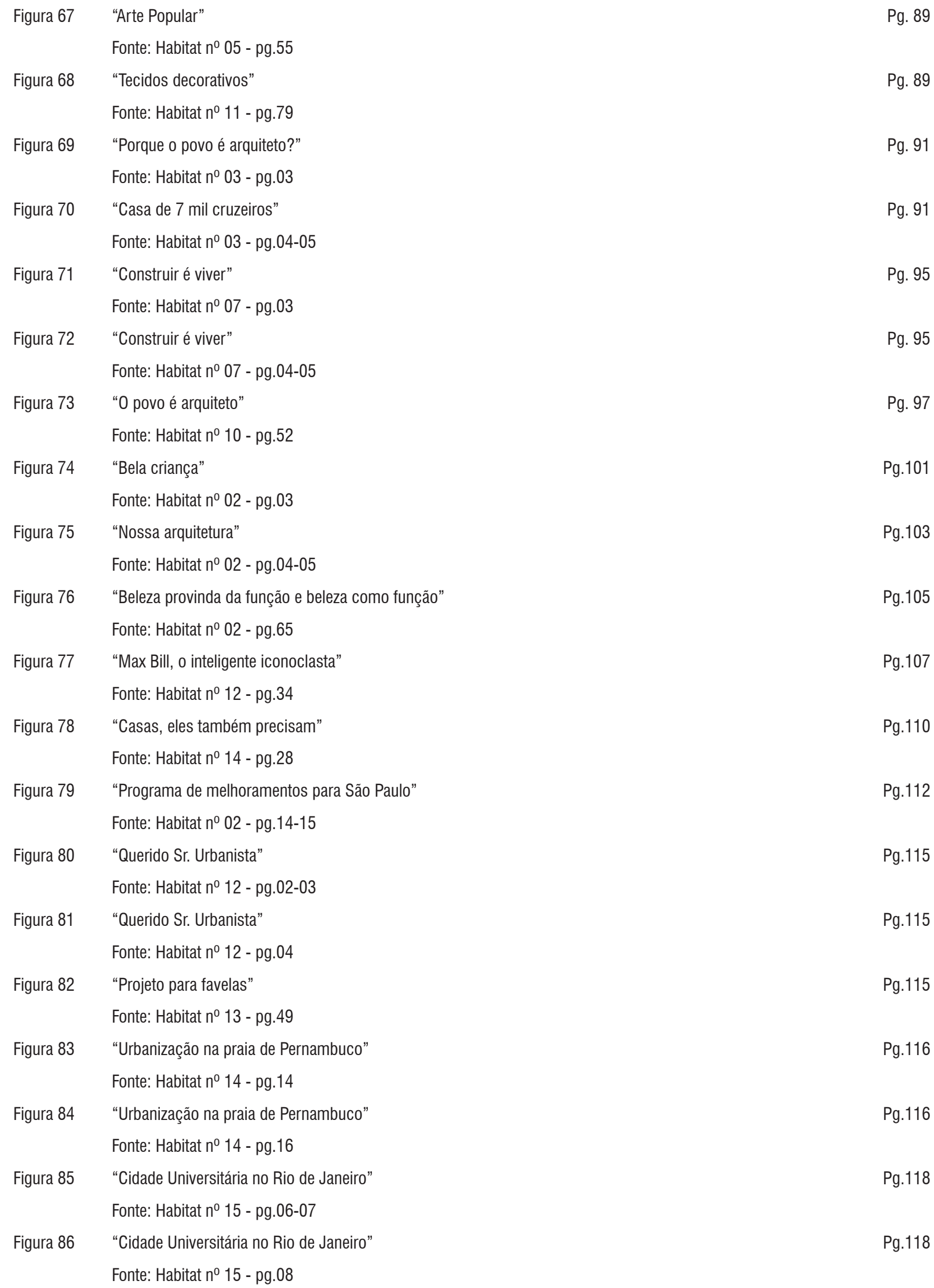


Figura 87 "Cidade Universitária no Rio de Janeiro"

Fonte: Habitat $n^{0} 15$ - pg.11

Figura 88 "Taba Guaianases"

Pg.120

Fonte: Habitat no 14 - pg.04-05

Figura 89 "Taba Guaianases"

Pg.120

Fonte: Habitat $n^{0} 14$ - pg.06-07

Figura 90 "Prédio 'Nações Unidas"

Pg.122

Fonte: Habitat n ${ }^{0} 12$ - pg.10-11

Figura 91 "Museu a beira do oceano"

Pg.123

Fonte: Habitat n $n^{0} 08$ - pg.08-09

Figura 92 "Os jardins de Burle Marx"

Pg.126

Fonte: Habitat $n^{0} 03$ - pg.09

Figura 93 "Uma exposição de Burle Marx"

Pg.126

Fonte: Revista Habitat n ${ }^{0} 08$ - pg.76-77

Figura 94 "Arquitetura de Sérgio Bernardes"

Pg.128

Fonte: Habitat $n^{0} 07$ - pg.11-15

Figura 95 "Duas construções de Oscar Niemeyer"

Pg.128

Fonte: Habitat $n^{0} 02$ - pg.06-07

Figura 96 "Duas construções de Oscar Niemeyer"

Pg.128

Fonte: Habitat $n^{0} 02$ - pg.10-11

Figura 97 "0 antigo e o novo Itamaratî"

Pg.130

Fonte: Revista Habitat no 13 - pg.30-31 
Sumário

Agradecimentos

Resumo

VII

Lista de llustrações

IX

Introdução

1. A revista Habitat de Lina Bo e Pietro Maria Bardi

1.1. 0 perfil de uma revista, a relação com o MASP

1.2. A experiência italiana de Lina e Bardi e a revista Habitat

1.3. O panorama cultural de São Paulo no momento da publicação da revista Habitat

1.4. Lina, Bardi e colaboradores

56

2. A Arquitetura na revista Habitat

67

2.1. Habitat e a arquitetura popular

88

2.2. Habitat e a arquitetura moderna brasileira

99

Considerações finais

133

Bibliográfia

139

Anexos:

Anexo 1: Índice do Expediente da Revista Habitat

98145,451

145

Anexo 3: Conversa com o Prof. Flávio Motta

176

Anexo 4: Conversa com Luís Hossaka

178

Anexo 5: Correspondências -arquivo histórico da Biblioteca do MASP

182

Anexo 6: Correspondências -arquivo histórico do Instituto Lina Bo e Pietro Maria Bardi 


\section{Introdução}

A revista Habitat, bastante lida e comentada em seu tempo, hoje rondaria 0 esquecimento não fossem os pesquisadores que se dedicam ao período em que esteve em circulação, os quais sistematicamente recorrem a ela a fim de encontrar valioso material que alimenta os mais diversos campos de trabalho. Afinal, Habitat é uma revista de cultura em que arte, arquitetura, design, cinema, teatro, bailado e fotografia aparecem inseridos no universo de ação cultural no momento em que São Paulo consolidava-se como metrópole.

Partimos neste trabalho da análise do Expediente da revista Habitat, a qual deu início a um olhar sobre o conjunto das publicações, fundamental na determinação do recorte desta pesquisa: os primeiros quinze números. Deles analisamos em um primeiro momento as características que a fazem particular entre as demais revistas do período - sua ligação com o Museu de Arte de São Paulo (MASP), a diversidade de assuntos que aborda, a decisiva participação de Pietro Maria Bardi e Lina Bo, o contexto histórico e a presença de seus colaboradores. No segundo momento, nos dedicamos a arquitetura divulgada em Habitat, sua eleição, os valores que pretende propagar e o diálogo com a crítica internacional, que juntos colaboram para a consolidação da arquitetura moderna no país.

A organização e direção de Habitat em seu período inicial por Pietro Maria Bardi (1900-1999) e Lina Bo (1914-1992) atribuíram características particulares aos seus primeiros anos, o que faz com que a revista seja lida aqui como inseparável da vida e trajetória desses dois intelectuais que alimentaram a cena cultural da capital paulista e do país. À frente de importantes instituições como o MASP (1947) e o MAM-Bahia (1960), e envolvidos em diversas atividades, Bardi e Lina desempenharam papel de destaque no desenvolvimento das artes e da arquitetura no Brasil.

A íntima ligação de Habitat com o MASP, com o Instituto de Arte Contemporânea (IAC) e com o Studio de Arte Palma, fazem com que a revista seja lida neste trabalho como parte de um projeto maior de ação no campo cultural idealizado por Pietro e Lina. Assim as páginas da revista colaboram intimamente na divulgação de atividades e ideais compartilhados por essas instituições.

0 casal define o caráter da revista como uma publicação que procura apresentar e discutir as diversas linguagens do campo cultural inscritas em um espírito moderno. Desta forma Habitat apresenta-se "plural" nos temas que 
aborda; no formato que os apresenta; nas pequenas notas, nos curtos ou longos artigos; nos documentos e textos consagrados; nos comentários sobre a recente produção nacional do cinema, teatro, dança, entre outras; na seção de opinião com as "Crônicas de Alencastro"; e na divulgação e crítica de arquitetura moderna por meio de textos, projetos, ilustrações e fotografias.

Por isso, dedicamos neste trabalho um espaço especial ao percurso individual dos Bardi na Itália no período anterior ao segundo pós-guerra, onde estiveram envolvidos em atividades editoriais que são vistas aqui como experiências fundamentais para a realização de Habitat como uma revista que já nasce madura.

Também a diversidade marca os colaboradores da revista. Vindos de diversos campos de atuação, não constituem um grupo que se organiza a partir da revista, mas colaboram para um projeto orientado pelas idéias do casal em que a questão da "formação" de um público parece evidente.

A arquitetura tem lugar especial, tanto pela parcela que ocupa na revista, quanto pelo envolvimento que seus organizadores guardam com 0 tema. A valorização de uma arquitetura racionalista, pautada pelos aspectos sociais e seus valores, define a eleição por uma arquitetura "artisticamente social" que abre em Habitat espaço para a arquitetura popular ao lado da arquitetura moderna.

A defesa dos mesmos valores define na revista o diálogo com a crítica internacional. A partir do questionamento do excesso de formalismo presente na arquitetura moderna brasileira, representado na revista pelo design suíço Max Bill, Habitat se mostra solidária à consolidação de uma arquitetura comprometida com a sociedade, endossando a discussão com textos e projetos que buscam o amadurecimento da produção local.

Ainda o papel do arquiteto e urbanista no planejamento das cidades, que enfrentam já nos anos 50 o reflexo do crescimento desordenado e do adensamento indiscriminado, aparece como uma preocupação constante na revista, que apoiada nos princípios propagados pelos CIAMs apontam soluções e convocam os arquitetos para a ação.

0 cruzamento dos diversos planos de discussão do complexo universo cultural apresentado e a clareza das intenções que os une em Habitat, confirma a importância da revista na constituição da arquitetura moderna em São Paulo e na revisão do papel do artista-arquiteto na sociedade moderna. 


\section{Uma análise do Expediente da revista Habitat}

Com a sistematização das informações presentes no Expediente de cada um dos 84 números que a revista publicou ao longo de seus quatorze anos de existência, compreendidos entre outubro de 1950 e dezembro de 1965 (ANEXO 1 - Índice do Expediente da revista Habitat), foi possível identificar diferentes momentos a partir da análise das mudanças de direção, de sua periodicidade e distribuição.

Inicialmente, quando ainda na definição do Projeto de Pesquisa, trabalhávamos com a classificação da revista em três diferentes fases editoriais definidas pela permanência de nomes em seu cargo de direção. Estas fases - a primeira marcada pela direção de Lina Bo e Pietro Maria Bardi, a segunda, com a direção de Abelardo de Souza e por fim, a terceira, com a presença de Geraldo Ferraz - eram sugestões de Miranda ${ }^{1}$ adotadas por nós num primeiro momento e depois questionadas após uma análise detida no Expediente e no conteúdo das publicações.

Identificamos que seu corpo de colaboradores além de sofrer alterações, fato comum a uma instituição de "vida longa", passou por diferentes formas de organização pela qual definimos dois grandes períodos. 0 primeiro, com uma organização "centralizada" a partir da presença de um Diretor Geral, ao qual caberia a coordenação dos diversos assuntos e temas abordados pela revista; e o segundo caracterizado pela descentralização, quando há a extinção do cargo de Diretor Geral substituído pelos Diretores de Seção, aos quais caberia a coordenação de uma das grandes áreas a que Habitat se dedicaria: arquitetura, artes plásticas, literatura e teatro.

Em ambos os períodos, e durante toda a vida da revista, há a permanência do nome de Geraldo Serra no cargo de Diretor Responsável. Segundo depoimento de Luis Hossaka², o jornalista Geraldo Serra fazia "a frente" da Editora Habitat, cujo proprietário Rodolfo Klein, que aparece como redator a partir da publicação de número 25 , por ser estrangeiro não poderia assumir este papel diante da legislação brasileira.

Neste estudo nos deteremos ao primeiro período, o de coordenação centralizada e onde se destacam as figuras de Lina Bo e Pietro Maria Bardi. Durante este período, restrito aos quinze números iniciais da revista, é possível notar a alteração por três vezes dos nomes que assumem sua coordenação a partir do cargo de Diretor Geral:

\footnotetext{
${ }^{1}$ Sugestão encontrada na dissertação de mestrado que procura analisar a crítica nas revistas de arquitetura dos anos 50. Ver MIRANDA, Clara Luiza. "A crítica nas revistas de arquitetura nos anos 50: a expressão plástica e a síntese das artes". Departamento de Arquitetura e Planejamento, Escola de Engenharia de São Carlos, Universidade de São Paulo,1998. ${ }^{2}$ Depoimento dado por Luis Hossaka a esta pesquisadora na Biblioteca do MASP em março de 2006.
} 
de outubro de 1950 a dezembro de 1952, entre as edições de número 1 a 9, 0 cargo é ocupado pela arquiteta Lina Bo que em 1953 é substituída, entre os números 10 e 13, por Flávio Motta; novamente no início de 1954, nos números 14 e 15, Lina retorna, desta vez acompanhada oficialmente pelo marido e diretor do MASP, 0 crítico de arte Pietro Maria Bardi. Os fatos que envolvem essas alterações serão explicitados adiante, quando tentaremos delinear o percurso desses personagens no contexto cultural paulistano neste período.

Fazendo a transição entre o período de direção centralizada e descentralizada, Abelardo de Souza, na revista $n^{\circ}$ 16, inaugura a Direção de Arquitetura, cargo ocupado ao lado dos Diretores de Artes Plásticas, de Literatura e de Teatro, respectivamente José Geraldo Vieira, Maria de Lourdes Teixeira e Ruggero Jacobbi. Apesar de não nos dedicarmos à análise deste segundo momento da revista, acreditamos que Abelardo leva depois para a seção de arquitetura, que ficará sob sua direção entre os números 16 e 24, muito do espírito que o marcara como um dos principais colaboradores e parceiros de Lina e Pietro nos primeiros anos de Habitat.

A partir da saída de Abelardo em novembro/dezembro de 1955, nota-se a estabilidade nos cargos que são reduzidos a Direção de Arquitetura, no qual figura Geraldo Ferraz e a Direção de Artes Plásticas, na qual permanece José Geraldo Vieira. Essa redução indica uma alteração nos interesses de Habitat, verificada nos índices das edições em que paulatinamente ficam escassos artigos dedicados a outras áreas de interesse, como teatro, cinema, fotografia, design etc.; características que permanecem até a extinção da revista na edição de n 84, em dezembro de 1965.

Essas mudanças no quadro de direção implicam alterações em suas características gerais, como: alterações nos nomes dos colaboradores, possivelmente ligados por laços pessoais e profissionais ao diretor; no conteúdo da revista, como a valorização ou não de determinados assuntos; alteração do recorte territorial, entre outros aspectos que definem um Projeto Editorial possivelmente alterado ao longo da vida de Habitat e que esta pesquisa não se propõe a analisar por demandar um compromisso que não conseguiríamos cumprir.

Por meio da análise do Expediente da revista também foi possível notar a alteração da periodicidade de Habitat, 0 que pode indicar dificuldades encontradas em diferentes momentos para sua realização. A trimestralidade apresentada nas primeiras 13 publicações pode ser lida como um período de dificuldades comum ao início de um projeto. A partir de janeiro de 1954 até final de 1955, do número 14 até 0 25, Habitat passa a ter publicação bimestral, que coincide com o retorno oficial de Lina à direção geral ao lado de Pietro (números 14 e 15), as comemorações do aniversário do IV Centenário de São Paulo, a inauguração do Parque do Ibirapuera e a II Bienal 
de Artes, evento que apesar de Habitat ter se mostrado crítica em relação a este último, ocupou grande parte de suas publicações no período ${ }^{3}$. Durante aproximadamente um ano, entre janeiro 1956 e fevereiro de 1957, tem espaço publicações mensais (do número 26 ao 39) que coincidem com a entrada de Ferraz nos cargos diretivos. Novamente, em março de 1957, Habitat volta a bimestralidade (do número 40 ao 63). Anunciando um período de dificuldades, a partir de janeiro de 1961, no $n^{\circ} 64$, retorna a trimestralidade que marcou seu início e que culmina com a interrupção das publicações no $n^{\circ} 84$, publicação relativa a julho /dezembro de 1965. Habitat é extinta no mesmo período em que outras publicações também fecham suas portas, um período marcado por profundas mudanças políticas em que a censura assola as editoras e a educação e a cultura ficam sob 0 controle militar.

Analisando ainda o Expediente das revistas é possível notar diferentes formas de distribuição das publicações e assim 0 alcance de sua "missão". Apenas a partir do n 3, a revista conta com um Distribuidor no Brasil, com sede no Rio de Janeiro. Na revista n¹0 passa também a contar com um Distribuidor na Argentina. Mas é nas edições de números 11 a 13, já sob a direção de Flávio Motta, que a representação e distribuição de Habitat se pulveriza, primeiro com representantes no Rio de Janeiro, Portugal e Espanha; e depois em Salvador, Porto Alegre e EUA. Com a saída de Motta a revista deixa de publicar essa informação que só volta a aparecer no $\mathrm{n}^{\circ}$ 36 (novembro de 1956), onde figura a representação no Rio de Janeiro e Distrito Federal, em Salvador, Recife e Belo Horizonte, na Argentina, no Uruguai e em Portugal. A partir do n 40 (março/abril de 1957) a distribuição para o território nacional volta a ser centralizada no Rio de Janeiro.

${ }^{3}$ Na revista $n^{0} 14$, Habitat dedica longo artigo sobre a II Bienal, o que se repetirá na edição de nº 16 que publica também artigo sobre a construção do Parque do Ibirapuera. 


\section{A revista Habitat de Lina Bo e Pietro Maria Bardi}

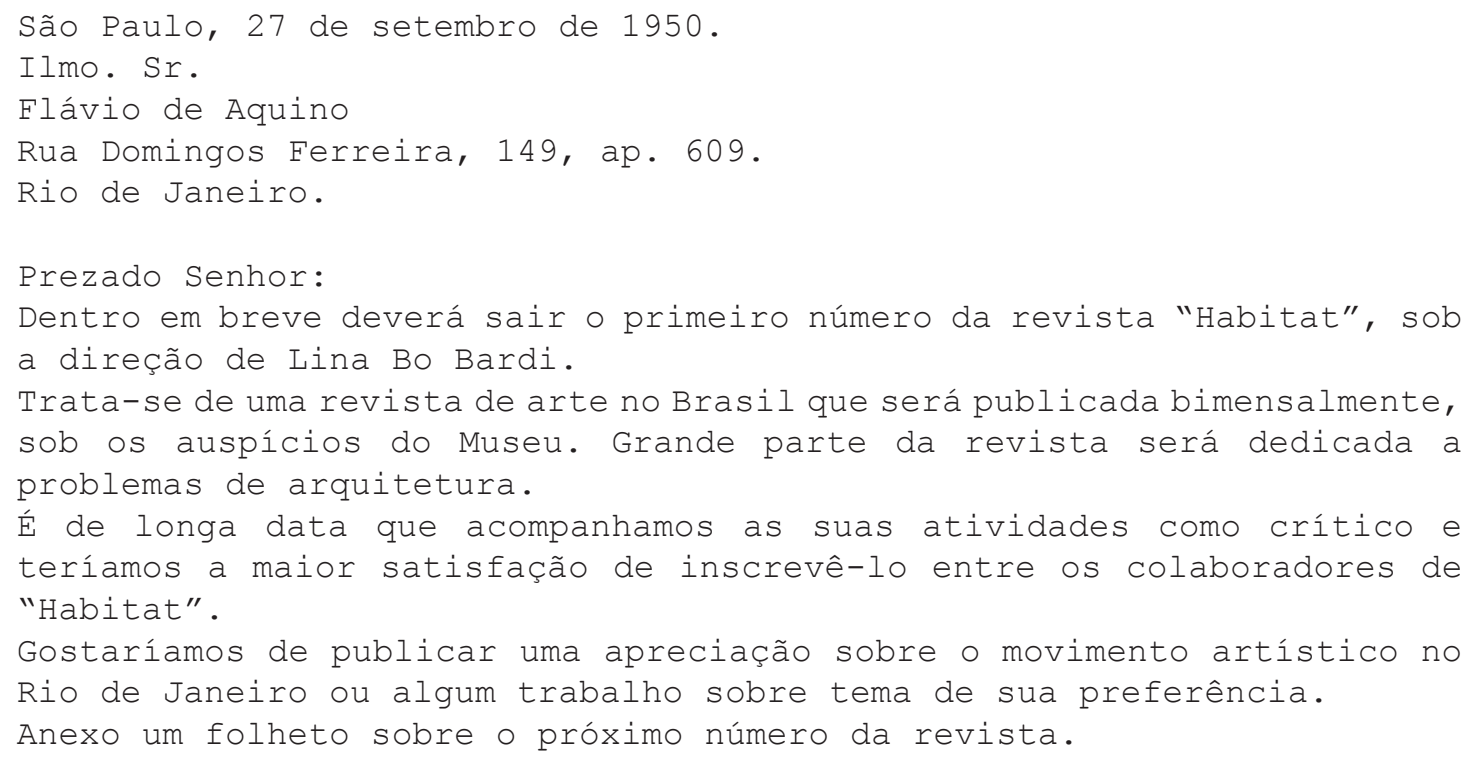

A correspondência encontrada entre os documentos do Arquivo Histórico do Museu de Arte de São Paulo, provavelmente uma entre tantas que Bardi enviara aos intelectuais a fim de conquistar um corpo de colaboradores para a revista no período que antecede a primeira publicação de Habitat, identifica sua ligação com o Museu e 0 interesse especial pela arquitetura, produção que será apresentada ao lado de outras atividades como as artes plásticas, o desenho industrial, a publicidade, a fotografia, o cinema, a música, a fotografia etc. A ligação com uma instituição nova e vibrante como o MASP e a divulgação e crítica do conjunto crescente de atividades artísticas desenvolvidas em São Paulo, farão de Habitat um periódico ímpar no cenário paulistano.

Incluir a arquitetura no campo das artes não será uma tarefa solitária de Habitat; anos antes outros movimentos artísticos locais, como o Salão de Maio, colaboraram para incluir a arquitetura como pauta nas discussões artísticas. Essa tarefa, assumida neste momento pela revista, em parceria com o MASP, define-se pela construção de um discurso de modernidade afinado com as artes gráficas, o desenho industrial e todas as produções artísticas comprometidas com a construção de uma sociedade moderna. As atividades promovidas pelo Museu reforçam o caráter de divulgação da arquitetura por meio de exposições, como a de Le Corbusier, Lúcio Costa e Max Bill, e também de conferências de Oscar Niemeyer e Henrique Mindlin, entre outras. 
1 a 15 . As capas das primeiras quinze publicações da revista Habitat: revista das artes no Brasil, que utilizavam-se dos assuntos que a publicação iria abordar para ilustrá-las. Sua autoria é atribuída a Lina Bo, que além de dirigir a revista era responsável pelas questões gráficas, as quais servia-se da experiência acumulada na Itália, onde trabalhou como ilustradora de importantes periódicos. É possível notar ainda, uma alteração no projeto gráfico nas edições de $n^{0} 14$ e 15 , que coincidem com o retorno de Lina e Pietro, ausentes do Brasil nas quatro edições anteriores.

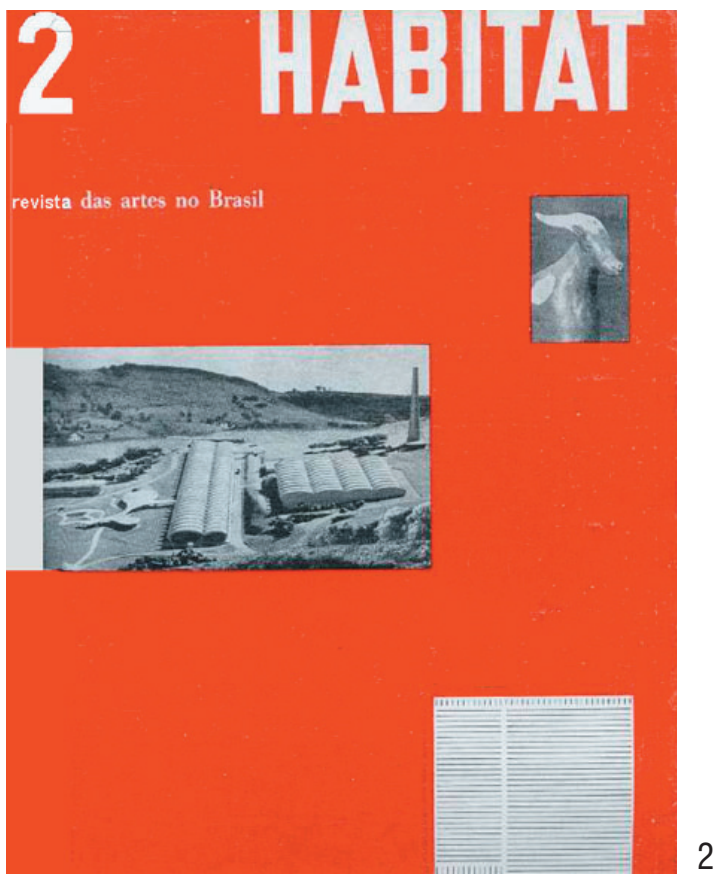

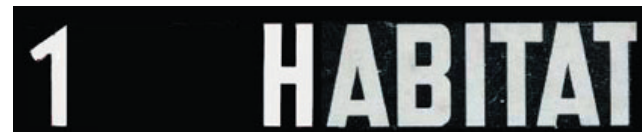

1
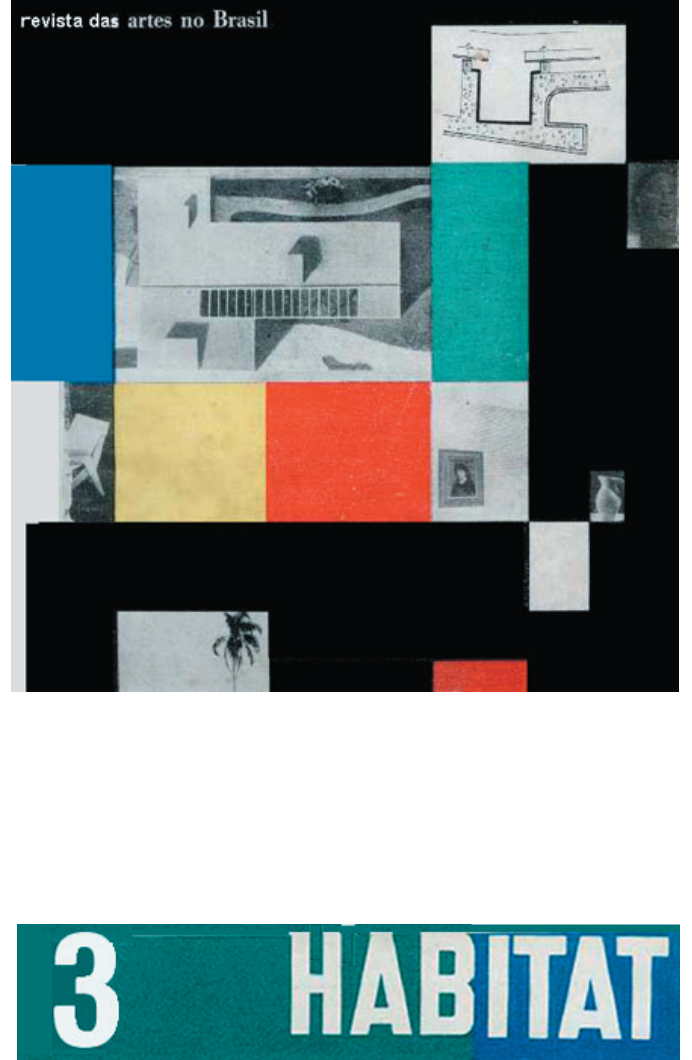

3

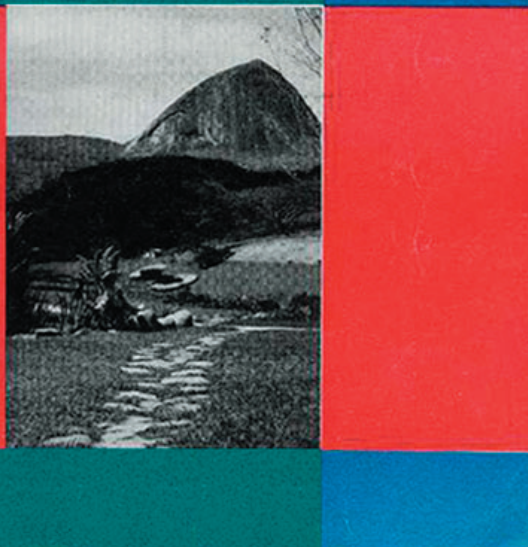



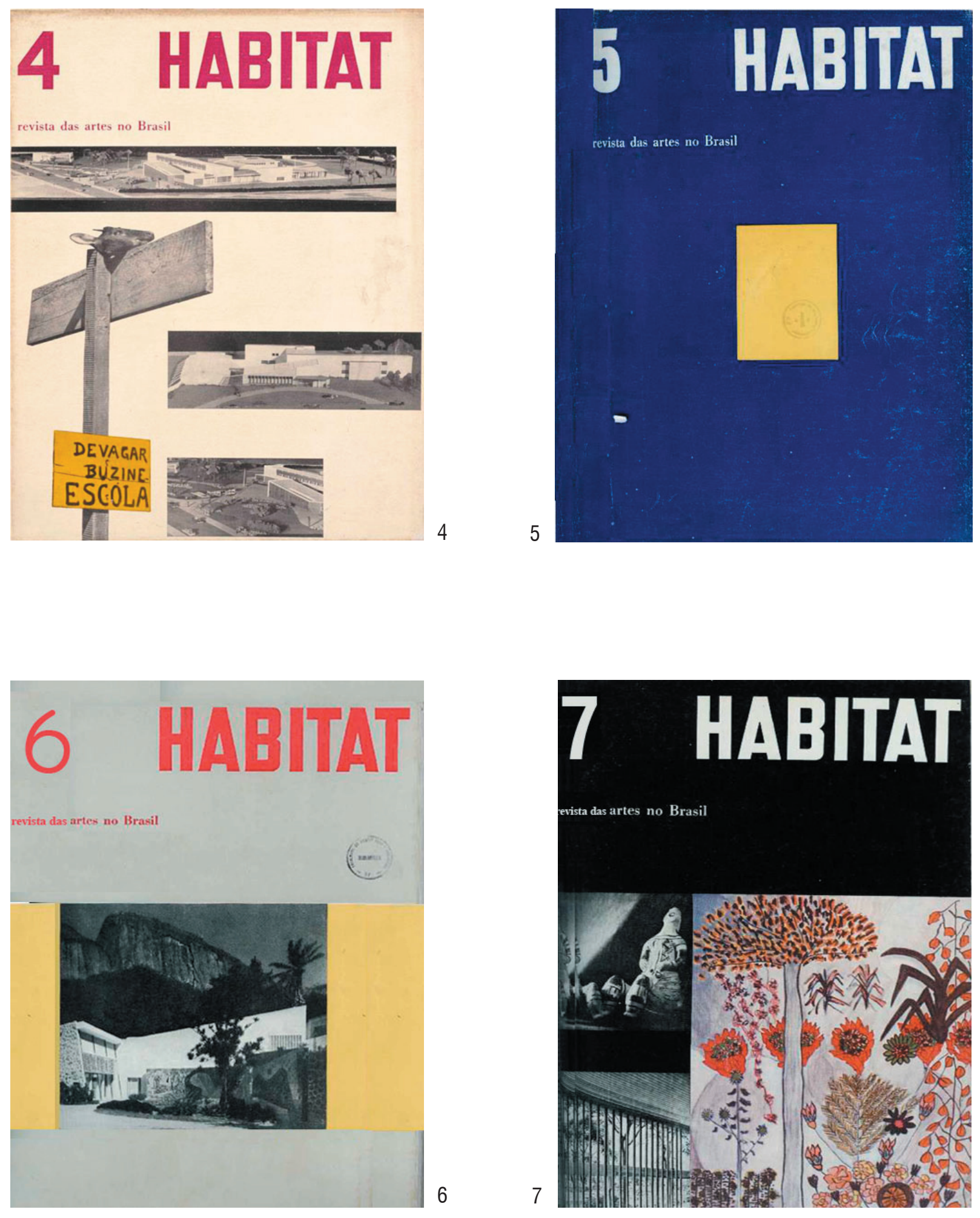

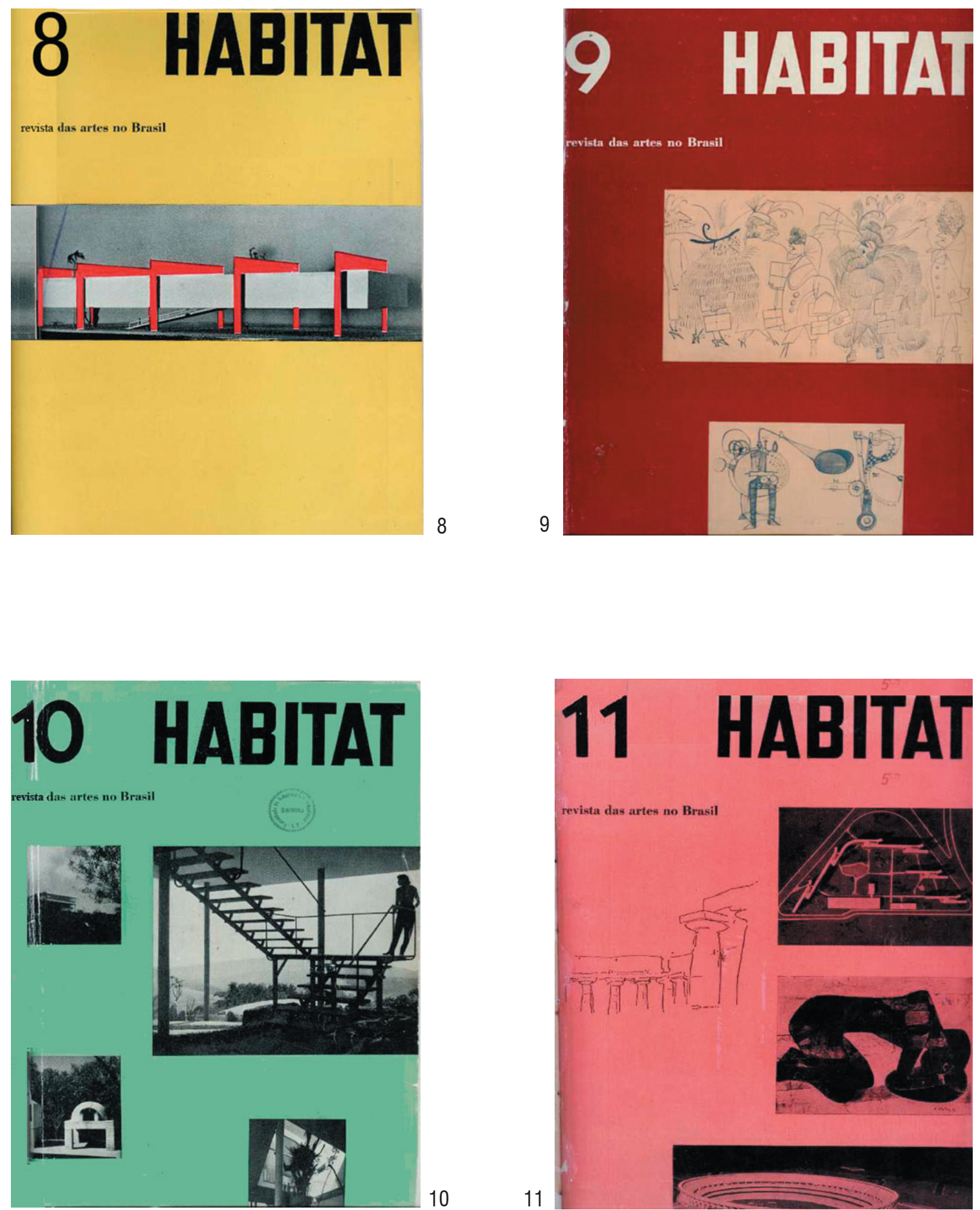

sts?
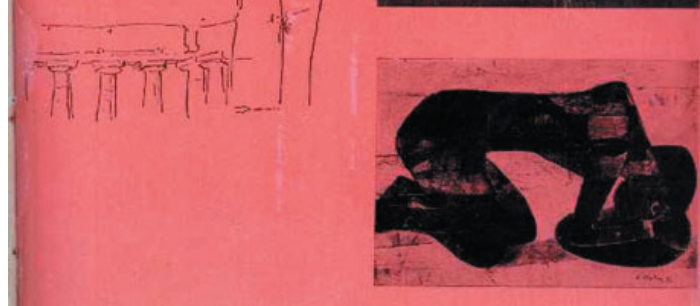

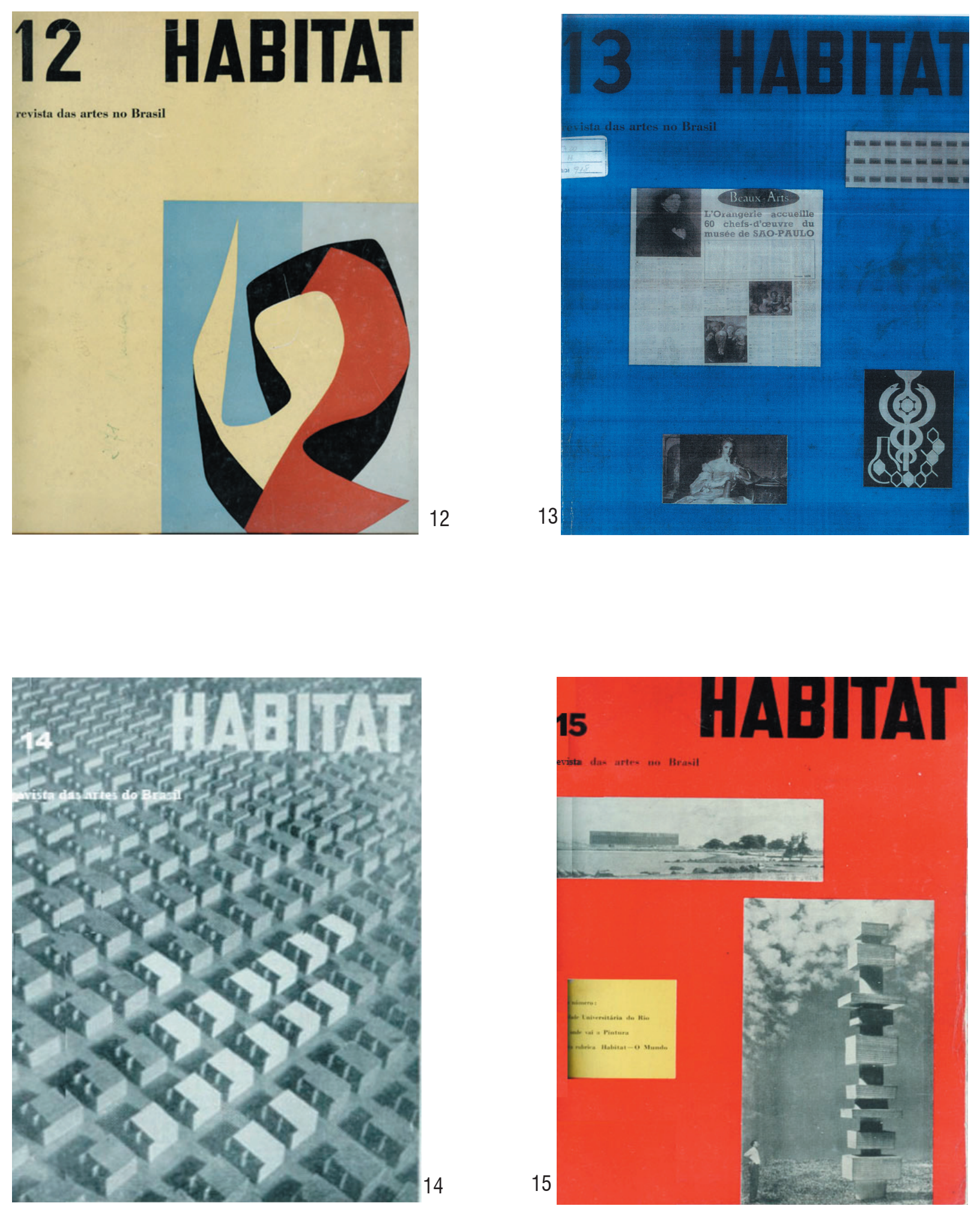


\title{
1.1. 0 perfil de uma revista, a relação com o MASP
}

\begin{abstract}
"A história das artes no Brasil continua ainda em grande parte inédita: por enquanto não passa de uma crônica contemporânea que progride com surpreendente celeridade. Assim é que o passado tão rico em temas para a reevocação e a efervescente atividade do presente não encontrem ainda uma documentação e uma informação adequada à realidade e a sua importância, embora dia a dia aumente o desejo de se conhecer o que se faz no país e fora dele em matéria de arte ${ }^{1}$. Basta para tanto refletir sobre 0 extraordinário incremento da arquitetura moderna, o impulso dado à cultura pelos novos museus, as afirmações da pintura, o surto das artes industriais para não falar da difusão da música e da sua divulgação para além das fronteiras, e do entusiasmo com que esta sendo encarado o problema do teatro e do cinema. (...) Estes cadernos que deverão sair de três em três meses em caráter experimental, pretendem traçar 0 conjunto destas atividades." ${ }^{2}$
\end{abstract}

Com essas palavras tem início o editorial da revista Habitat, no qual o autor se propõe a preencher uma lacuna existente no setor das artes no Brasil $^{3}$ e esclarecer os objetivos e a linha intelectual da revista. Para um europeu, que acabara de chegar a essas terras, a vastidão ainda inexplorada no campo da produção cultural local parecia um banquete para se refestelar.

É dessa perspectiva que o casal Pietro Maria Bardi e Lina Bo viam o Brasil: um vasto campo para realizações no setor das artes, principalmente se comparado ao que haviam vivido na Itália durante a guerra. 0 desejo de concretizar os projetos idealizados durante os últimos anos na Itália, fez dos primeiros anos no Brasil um período de intensas atividades no Museu de Arte de São Paulo, na revista Habitat, no Instituto de Arte Contemporânea (IAC) e no Studio de Arte Palma. Juntas essas instituições configuram a ação de um projeto de modernidade pelo qual o casal já vinha comprometido desde a atuação no campo cultural italiano.

No Brasil este projeto de modernidade tem como bandeira a realização do Museu de Arte de São Paulo, idealizado por Assis Chateaubriand e que coube a Bardi a realização. A aliança entre 0 italiano e 0 grande

\footnotetext{
${ }_{1}$ Grifo nosso.

2 EDITORIAL. Habitat, São Paulo, n 1, out./dez., 1950.

${ }^{3}$ Lugar já pleiteado por Lorival Gomes Machado, no qual o autor também denuncia a lacuna existente na historiografia da arte brasileira a qual se propõe a preencher: "0 primeiro historiador da arte brasileira, sistemático e com visão geral do desenvolvimento cultural, erudito e capaz de interpretação, este ainda não o tivemos. Monografias soberbas aparecem por vezes e, em muitas oportunidades, uma monografia - por exemplo, sobre o Aleijadinho - vale pelo estudo de uma época. Não basta, contudo. Ficarão provisoriamente faltando aqueles estudos em que, mais que 0 grande artista ou o período bem caracterizado, constituam as ligações, as passagens intermediárias, as transições, o interesse central do historiador. E infelizmente, só é história verdadeira a que mostra como a cultura transita se transformando, como os padrões adquirem uma medida de evolução, de crescimento". MACHAD0, Lourival Gomes. Retrato da arte moderna do Brasil. São Paulo: Departamento de Cultura, 1947, p.11.
} 
empresário no setor das comunicações inicia-se ainda em 1946, no primeiro encontro ocorrido por ocasião da “Exposição de pintura italiana antiga (séculos XIII e XVIII)", realizada por Bardi no saguão do edifício-sede do Ministério de Educação e Saúde, no Rio de Janeiro. Esse encontro, relatado em detalhes no livro de Fernando Moraes $^{4}$, no qual Chatô convida Bardi para dirigir seu ainda inexistente museu de arte antiga e moderna, revela muita da personalidade "aventureira" de quem fez o convite e de quem o aceitou. A partir daí, juntos na empreitada de reunir o valioso acervo do Museu, alia-se o poder ${ }^{5}$ do empresário à elite local e o conhecimento e os contatos na Europa do crítico de arte. Importante lembrar que Chateaubriand implementou no Brasil a primeira rede de comunicação nacional, o império dos Diários Associados ${ }^{6}$ que teve início em 1924 com a compra de seu primeiro impresso - 0 Jornal - no Rio de Janeiro.

Nesse sentido aliar-se a Chateaubriand na tarefa da realização de um museu de arte em São Paulo, o centro econômico do país, significava mais que um projeto com intenções culturais, mas a conquista de visibilidade, de poder político e garantia de projeção pessoal, fundamentais para um estrangeiro recém-chegado ao continente. Apesar de reconhecido galerista e polemista dos mais importantes periódicos italianos, pela falta de formação e informação da elite local, Bardi trazia uma tarefa não pouco difícil: a conquista da simpatia e da confiança do meio em que iria se estabelecer. A esses interesses, soma-se a possibilidade de ver aqui implantado 0 projeto pelo qual a arte, vista como conhecimento, aparece como agente de transformação social; projeto já proclamado pelas vanguardas européias e que Bardi e Lina assumem como desafio.

Sobre a "abrangência de propósitos e a generalidade de intenções" que o nascimento dos museus envolve, os quais o Museu de Arte de São Paulo não faz diferente, Lourenço (1999) indica a partir da construção de um histórico das instituições museográficas e do imaginário que as envolvem, a relação entre o mito das Musas (origem da palavra "museu") e a mitificação que os cercam?.

\footnotetext{
${ }^{4}$ MORAES, Fernando. Chatô o Rei o Brasil. São Paulo: Companhia da Letras, 1994.

${ }^{5}$ Muitas vezes o empresário utilizou seus veículos de comunicação como elemento de chantagem para "extrair" donativos generosos da aristocracia paulistana. Ver BARDI, Pietro M. Sodalício com Assis Chateaubriand. São Paulo: MASP/Sharp, 1982, e MORAES (1994), op. cit.

${ }^{6}$ Em 1954, após três décadas de expansão de sua rede de comunicações, o grupo dos Diários Associados compunha-se de vinte e oito jornais diários, vinte emissoras de radiodifusão, duas estações de televisão, três agências de notícias e de publicidade e quatro revistas. Cf. Diário de São Paulo, 17.3.1954, apud DURAND, José Carlos. Arte, Privilégio e Distinção. São Paulo: Perspectiva, 1989, p.122.

7 "As Musas, segundo a teogonia grega, descendem do criador supremo Zeus e de Mnemósina, a memória, sendo dotadas duma dupla finalidade: de um lado preservam a memória e transmitem o que já se fizera, de outro, criam e aperfeiçoam conhecimentos. Desta forma, o incentivo ao saber subverte o conservar, uma ordem repetitiva do sempre igual e reverenciadora do passado, dando lugar ao singular novo e intrépido." LOURENÇO, Maria Cecília França, Museus Acolhem o Moderno, São Paulo: Edusp/Hucitec, 1999a, p. 61.
} 
"0 discurso explicitado na implantação dos museus, através de decretos, estatutos e regimentos, carrega esse conjunto positivo ligado a Zeus: destinam-se a preservar, conservar, transmitir, educar, organizar, registrar, publicar, atualizar, integrar, patrimoniar, formar, disseminar - tanto a arte, a cultura, 0 estudo, as obras e os artistas, quando referências ao público, ao cidadão, às crianças, estudantes e tudo o que tem sido considerado como valor desejável."

Assim o MASP para efetivar essa "missão", muito mais que preservar e guardar tesouros busca a formação de um público apto ao deleite do ali exposto, e principalmente pronto a constituir uma sociedade na qual a cultura e as artes adquirem valor. Nessa missão, junto com o MASP, a revista Habitat pode ser vista como meio de ampliar os limites e alterar o gosto estabelecido, ultrapassando as fronteiras culturais da classe dirigente. Para tanto Bardi serve-se de um "modelo" que historicamente havia se mostrado eficiente: museu, escola e revista ${ }^{8}$, e do perfil dos museus americanos, entre os quais destaca-se o Museu de Arte Moderna de Nova York.

E é com o perfil das instituições americanas que o Museu de Arte de São Paulo é fundado em 19479. Com papel educativo e formador, o MASP altera o exemplo dos museus aqui existentes, como o Museu Nacional de Belas-Artes do Rio de Janeiro, e instaura uma instituição moderna com um significativo acervo permanente de arte italiana do século XIII ao XVIII, do impressionismo e tendências posteriores.

Como um museu vivo, o MASP contou em seus primeiros anos de funcionamento com Habitat - Revista das Artes no Brasil, que se apresenta como seu principal interlocutor divulgando de forma sistemática suas atividades, como as exposições de Le Corbusier, Max Bill e Burle Marx; seus cursos de cinema e música; e ainda, a partir de 1951, da inauguração do Instituto de Arte Contemporânea - um ateliê-escola em áreas ainda não exploradas no Brasil, abrangendo cursos de propaganda, de desenho industrial e comunicação visual, ateliê de "alta" costura e laboratório fotográfico, entre outros - esclarecendo sobre seus cursos e finalidades.

Na divulgação de suas intensas atividades, o Museu contou ainda com a rede de jornais e revistas dos Diários Associados ${ }^{10}$, os quais também serviram como meio e "arma" para a "angariação de fundos e donativos" entre a alta sociedade paulistana a fim de tornar possível 0 acervo do Museu. Acervo reunido em um breve período

${ }^{8}$ Como experiências anteriores figuram instituições européias do século XVIII que uniam as funções de conservar, educar e divulgar suas atividades, a fim de formar mão de obra especializa para 0 artesanato.

`Um ano após a inauguração do Museu de Arte de São Paulo por Assis Chateaubriand, é também inaugurado o Museu de Arte Moderna por Francisco Matarazzo. A competição existente entre os dois mais importantes empresários de São Paulo pode explicar a similaridade da proposta inicial, que ao longo da vida destas instituições vão caracterizando-se bastante particulares. Cada qual a sua maneira.

${ }^{10}$ Durand chama a atenção para a comum criação de fatos realizados por Assis Chateaubriand a fim de que rendessem campanhas especiais para os Diários Associados. Desse ponto de vista sugere que o Museu de Arte de São Paulo poderia ser visto como "mais uma das campanhas destinadas a alimentar de notícias seus órgãos de divulgação". Tal afirmação 


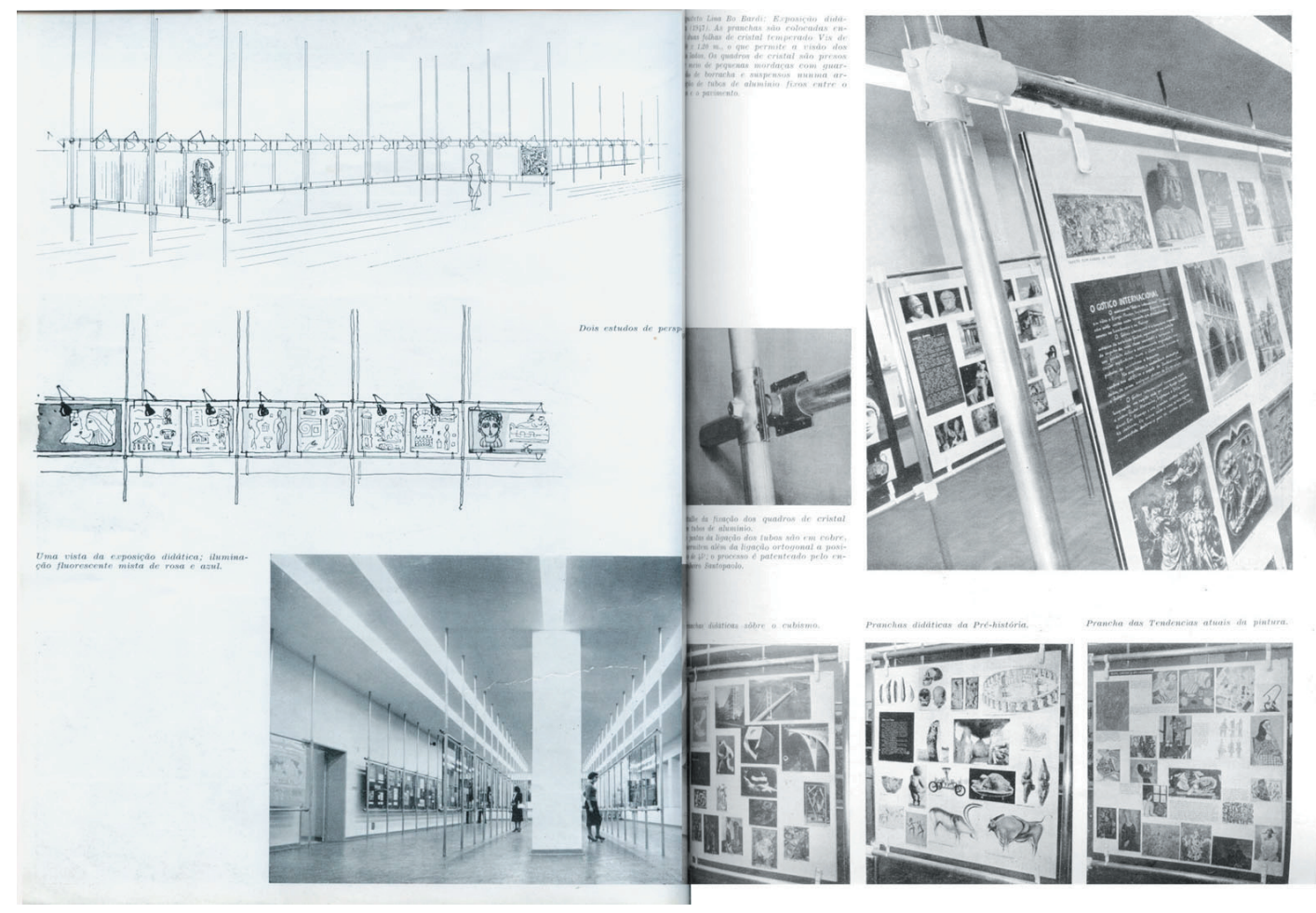

16. Páginas do "0 acervo da Pinacoteca", um entre os muitos artigos que Habitat divulga e que ilustra o caráter de "museu vivo" que o MASP assume em seus primeiros anos. Imagens da Exposição didática realizada em 1947e detalhes dos estudos do projeto expositivo, ambos sob a responsabilidade de Lina Bo .

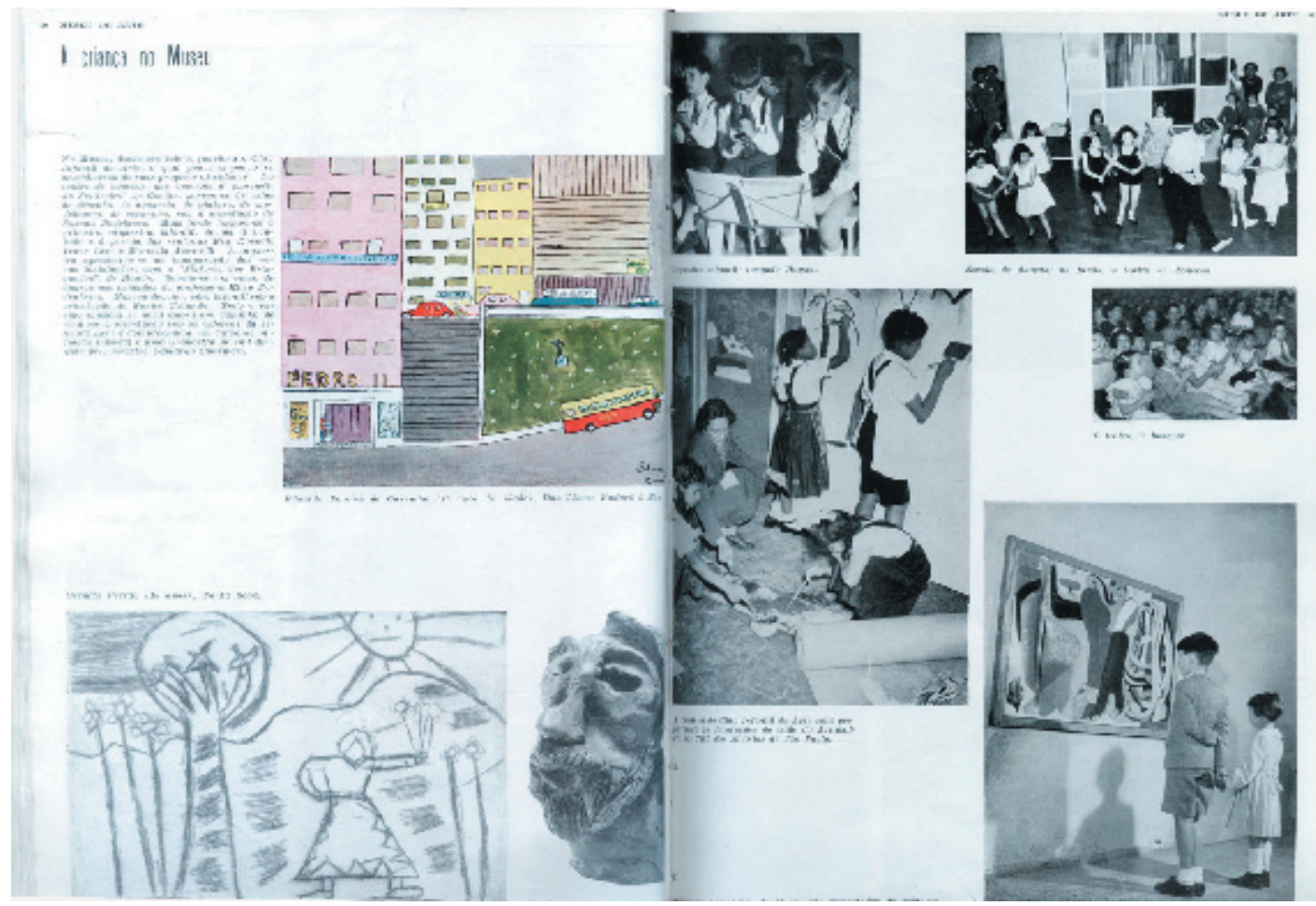

17. Entre o grande número de atividades do MASP, o Clube Infantil de Arte é divulgado no artigo "A criança no Museu" no primeiro número da revista. 
e cujo reconhecido valor incrementou o prestígio pessoal de Chateaubriand e o rendimento para seu grupo jornalístico ${ }^{11}$. Durand também indica 0 interesse particular de Chatô nos cursos de publicidade, desenho industrial e artes gráficas promovidos pelo MASP, os quais forneceriam profissionais especializados para atuar em seu parque editorial.

A ambição do museu idealizado por Chateaubriand ganhou complexidade e identidade ao ficar sua realização a cargo de Bardi, que viu na tarefa de concretizar 0 "museu de Chatô" a oportunidade de realizar o seu projeto moderno, através do Museu de Arte de São Paulo, da revista Habitat, do IAC e do Studio de Arte Palma, todos pautados pelos princípios do movimento moderno que, segundo Flávio Motta, guardava um "ingênuo" acreditar que estariam inaugurando aqui 0 projeto cultural moderno.

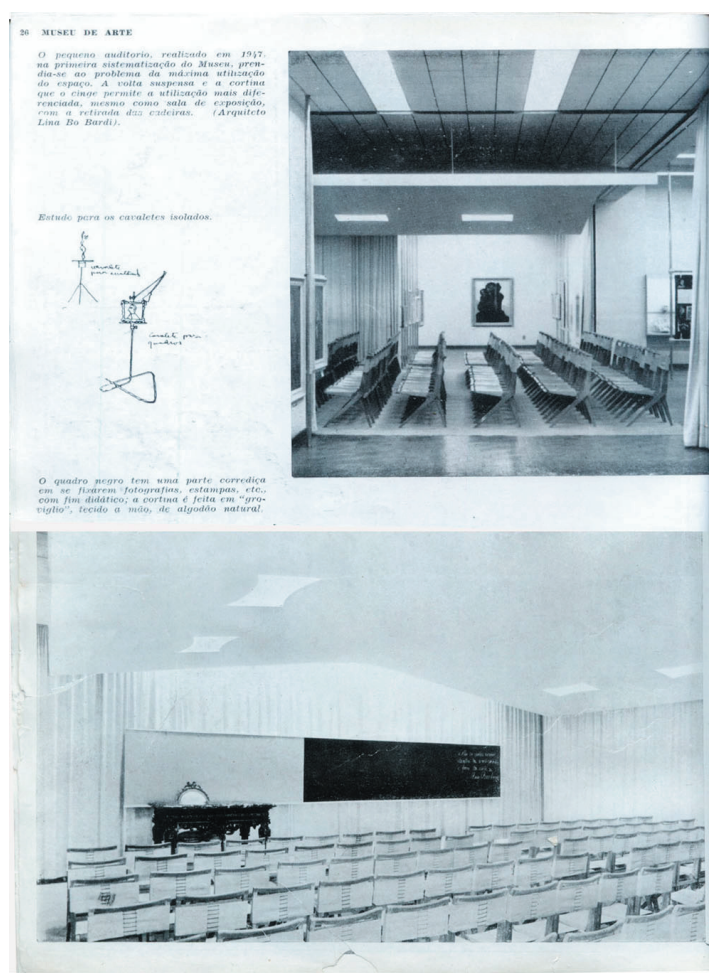

18. Em "Sinopse do Museu de Arte", Habitat publica o projeto de Lina Bo de adequação para as instalações da sede do MASP no Edifício Guilherme Guinle dos "Diários Associados", demonstrando a relação entre sua arquitetura e 0 projeto museográfico que iria abrigar.

Ainda que o MASP tenha sido a primeira iniciativa institucional museográfica com um projeto cultural estruturado, antes dele houve iniciativas particulares que partiam da própria classe artística:

“(...) como cursos artísticos informais e conferências capazes de agitar o meio, como já fizera Flávio de Carvalho no Clube dos Artistas Modernos (1932-1934), palestras e mostras internacionais e nacionais, como as ocorridas na Sociedade Pró-Arte Moderna de Segall (1932-1934), no Salão de Maio (1937-1939), ou mesmo algumas das realizações do Sindicato dos Artistas Plásticos, em especial ao sediar a Exposição Francesa, com visitas e palestras feitas por seus associados, em 1940, ou uma série enorme de mostras internacionais em 1937-1945, que foram acompanhadas por conferencias e publicações." 12

pode parecer um pouco apressada se olharmos a inauguração do Museu como um projeto maior de Chateaubriand no campo das artes plásticas. DURAND 1989, op. cit., p. 122.

${ }^{11}$ Outros exemplos apontam a afinidade entre controle de órgãos de imprensa e propensão ao patrocínio artístico. "No Rio de Janeiro, Niomar Sodré, do grupo proprietário de 0 Correio da Manhã, esteve entre os fundadores do Museu de Arte Moderna local. Adolpho Bloch comprou muita pintura, escultura e tapeçaria de artista nacional para as sedes de Manchete, volta e meia objeto de amplas reportagens ilustradas. (...) 0 industrial Isai Leirner, ligado ao Conselho de Administração do Museu de Arte Moderna de São Paulo e às Bienais, escolheu o saguão de um jornal (Folhas) para nele instalar uma sala de exposições com premiação anual, entre 1958 e 1961 (...)". DURAND 1989, op. cit., p. 125.

${ }^{12}$ LOURENÇ0, Maria Cecília França, Maioridade do Moderno em São Paulo. Anos 30 e 40, São Paulo: Edusp/Hucitec, 1999b, p.61. 

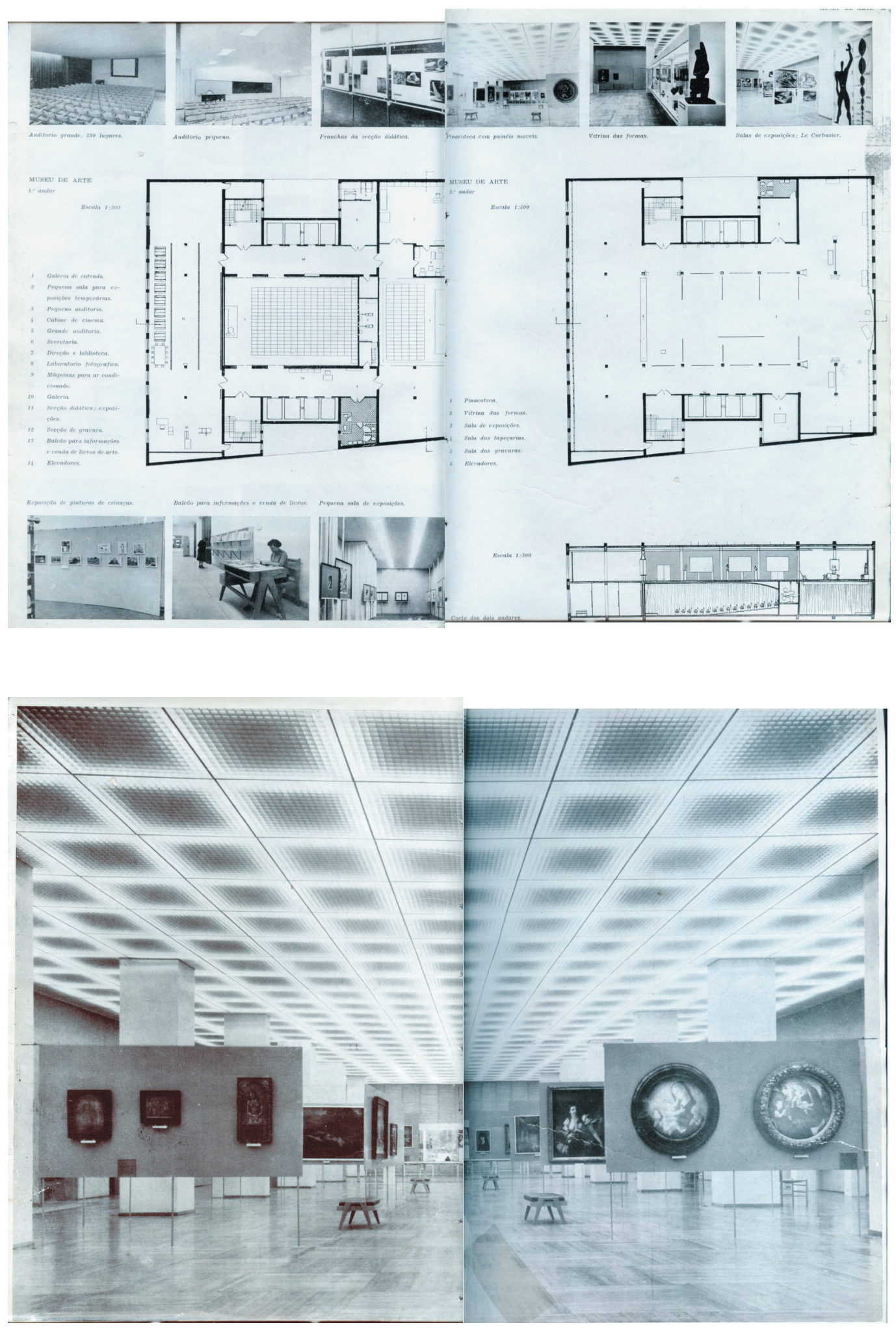

19 . Ainda outras páginas do artigo "Sinopse do Museu de Arte", que apresenta a partir de peças gráficas, o projeto arquitetônico do MASP e que chama a atenção para a flexibilidade do espaço e das atividades que iria promover. 20 . Imagem da Pinacoteca do Museu com painéis móveis que foram concebidos para abrigar o crescimento continuo do patrimônio. 
No mesmo sentido, porém em outra escala e com maior freqüência e ainda contando com a cadeia dos Diários Associados e com 0 apoio financeiro, são relevantes as atividades que o Museu realiza durante seu período inaugural, o número de conferências, o valor das publicações elaboradas e as importantes ações educacionais:

“(...) em 1947 implementam-se três deles: História da Arte, Monitores para o Museu, e Vitrinistas (...). Estes mantém-se em 1948 e, também, inicia-se o de música. Realizam-se, em 1949, um curso de cinema e outros dois, um destinado à educação infantil e outro à de adultos (...) Datam de 1950 um curso de gravura, um de musicologia e o primeiro de propaganda. No ano seguinte (1951) mantém-se o de propaganda, ampliando-se para cinema, fotografia, jardinagem e o Instituto de Arte Contemporânea, que formará os primeiros designers brasileiros." ${ }^{13}$

Por esse breve histórico fica patente que Bardi e Lina no MASP abriram entre um acervo de inestimável valor, espaço às novas manifestações artísticas, atuando bravamente no campo educacional e imprimindo assim seu projeto moderno. Projeto pelo qual Habitat atuou como um eficaz veículo formador e divulgador, além de tornar pública todas as atividades do Museu.

${ }^{13}$ LOURENÇO (1999a), op. cit., p.100.
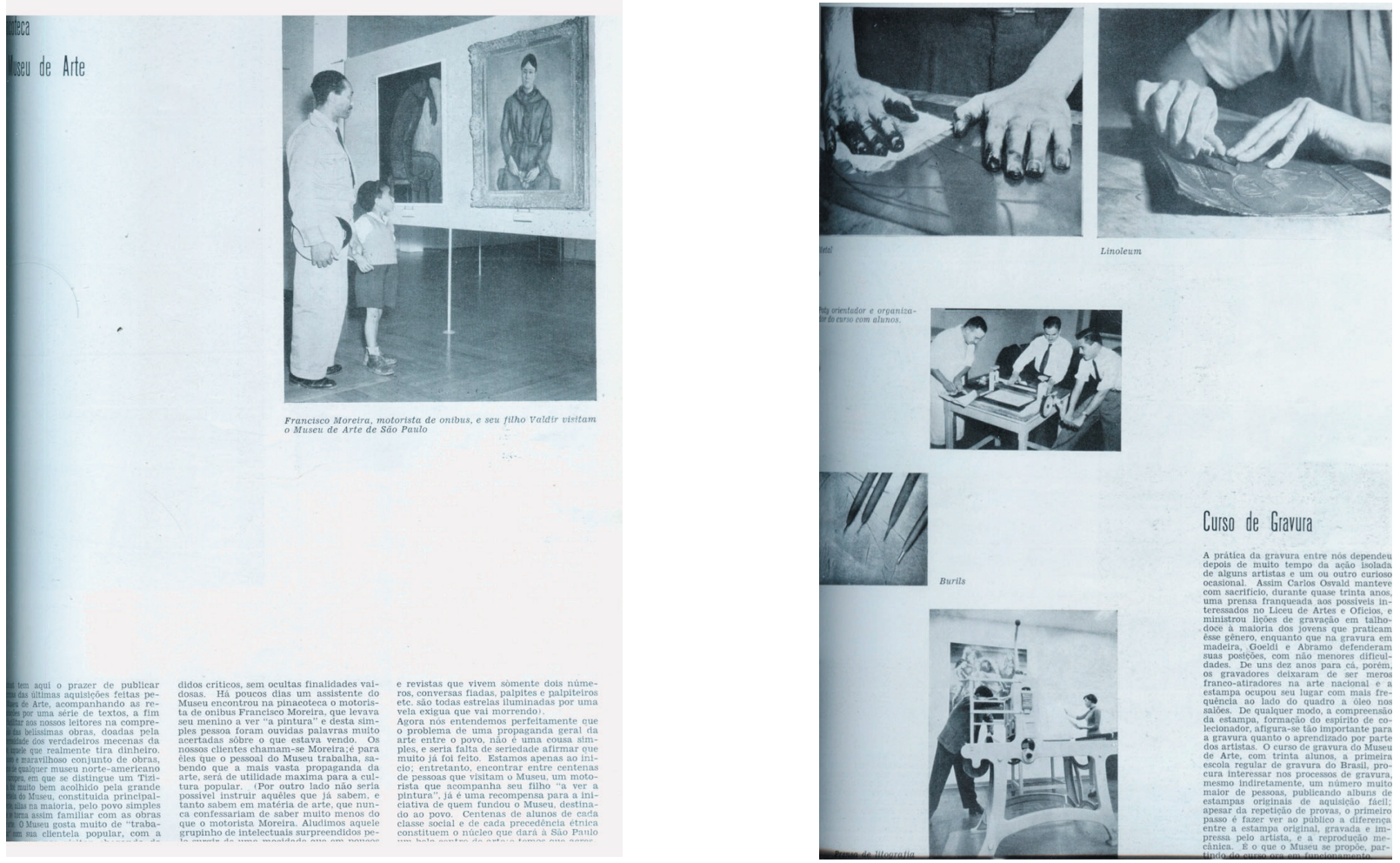

21. Com o título de "Pinacoteca do Museu de Arte" há em todos os números da revista um artigo dedicado as novas aquisiçoes de obras de arte pela Pinacoteca do Museu. Nesses Habitat esclarece sobre o valor da obra adquirida e realiza um breve histórico de seu autor.

22 . Divulgação de mais um dos cursos realizados pelo Museu, a primeira escola regular de Gravura do Brasil. 
Os primeiros anos de Habitat, fundada em 1950, têm em comum com o MASP não apenas o espaço físico, ambos sediados no edifício-sede dos Diários Associados, mas também Lina e Pietro integralmente envolvidos na realização desse projeto moderno. Por isso analisamos neste trabalho apenas os quinze primeiros números da revista, com publicações compreendidas entre outubro de 1950 e abril de 1954, período em que Habitat pode ser lida como uma revista do Museu de Arte de São Paulo, na medida em que se empenha na implementação e divulgação do mesmo projeto moderno a partir de uma ação formadora.

Essa preocupação pode ser observada na revista pelo tom didático que alguns artigos apresentam, principalmente os voltados à arte. Entre eles podemos destacar os que apresentam as novas aquisições da Pinacoteca do Museu de Arte, argumento que reincide em todas as primeiras quinze edições. No primeiro número 0 artigo explicita seu papel formador:

"Habitat tem aqui o prazer de publicar algumas das últimas aquisições feitas pelo Museu de Arte, acompanhando as reproduções por uma série de textos, a fim de facilitar aos nossos leitores na (sic) compreensão das belíssimas obras (...). 0 novo e maravilhoso conjunto de obras, digno de qualquer museu norte-americano ou europeu, em que se distingue um Tiziano, foi muito bem acolhida pela grande clientela do Museu, constituída principalmente, alias na maioria, pelo povo simples que se torna assim familiar com as obras de arte. 0 Museu gosta muito de 'trabalhar' com sua clientela popular, com a gente que vem nos visitar chegando da rua, e que entrando tira o chapéu, que olha com admiração e com respeito, que exprime seus comentários sem subentendidos críticos, sem ocultas finalidades vaidosas"14.

Artigos como esses além de valorizar as aquisições da Pinacoteca, buscam formar o público para seu deleite por meio da publicação de textos que acompanham as ilustrações das obras, descrevendo-as e esclarecendo sobre seu autor. Com caráter também didático, "Ex-votos e 'premessas'” de Alceu Maynard Araújo, apresenta uma pesquisa sobre "ex-votos", suas origens, categorias e relevância. 0 artigo tem texto ilustrado por imagens de monotipias de Mario Cravo e do acervo de fotografias do autor ${ }^{15}$.

Por esses artigos é possível afirmar que a revista Habitat busca, pelo seu conteúdo, atingir dois públicos distintos: um leigo que precisa "formar" e outro mais bem formado no qual é preciso "alterar" alguns conceitos preestabelecidos que emperram o pleno progresso cultural da capital paulistana.

Paralelamente às atividades que desenvolviam no Museu, Lina e Pietro estiveram à frente da direção de Habitat entre outubro de 1950 e abril de 1954. No mesmo momento em que no MASP, num pequeno e ativo

${ }_{14}$ PFEIFFER, W. Habitat, São Paulo, nº 1, out./dez. 1950, p. 35.

${ }^{15}$ ARAÚJO, A. Maynard. Habitat, São Paulo, nº 5, out./dez. 1951, p. 42. 
grupo coordenado por Pietro, Lina ao lado de Flávio Motta e Jacob Ruchti era responsável pela organização e divulgação das exposições, era também responsável pela coordenação da revista. Apesar de oficialmente somente a partir de janeiro de 1954, nas edições 14 e 15, o nome do casal Bardi aparecer oficialmente nas páginas do expediente - nos primeiros nove números o nome de Lina figura solitário como Diretor Geral, sendo depois substituído pelo nome de Flávio Motta nas edições 10, 11, 12 e 13 - uma forte onipresença impregna todas as quinze publicações com o mesmo espírito presente no Museu e em suas atividades.

Na primeira edição da revista Habitat, o Prefácio escrito por Lina Bo chama a atenção para a falta de documentação e informação no que se refere ao campo das artes no Brasil, e aponta a revista como a possibilidade de traçar um conjunto destas atividades: "0 incremento da arquitetura moderna, o impulso dado à cultura pelos novos museus, as afirmações da pintura, o surto das artes industriais, para não falar da difusão da música (...)". Assim, ao apresentar os diversos setores da cultura e das artes como foco da revista, o autor assume ainda o compromisso de compor um panorama unitário e lúcido dos fatos contemporâneos, estabelecendo uma relação com o passado ao "fundir os tempos numa só época; sem a baliza das classificações, dividindo 0 antigo do assim chamado moderno (...)".

0 interesse em unir os tempos está presente também no discurso de Bardi impresso nas páginas dos periódicos italianos, em que sustenta a tese de não separar a arte antiga da moderna. Em Habitat, logo no primeiro número, provavelmente é Bardi que publica "Frei Lodoli e a cadeira", artigo que introduz as páginas que seguem "Móveis novos". 0 interesse de Bardi por Lodoli, um precursor da arquitetura racional, é indicado por Tentori16 que utiliza as palavras do próprio Bardi para elucidá-lo: o Frei "não era arquiteto de fato, mas participava das coisas da construção como esteta; um divulgador de idéias que lhe vinham à mente por observações consideradas à luz de um maravilhoso bom senso: idéias em contraste com aquelas da maioria (...). Roma, onde esteve por cerca de vinte anos, Ihe sugeriu e fez desenvolver o culto a arquitetura, e foi esta a paixão da sua vida, sem todavia professá-la”.

0 artigo de Habitat transcreve o trecho "Socrate architetto" de Frei Lodoli indicando-o como "um dos espíritos iluminados na profecia da arquitetura racional e raciocinada”, precursor da associação entre material e técnica à forma. Este conceito introduz o segundo artigo em que é apresentada a produção de cadeiras do Studio de Arte Palma, de autoria de Lina Bo e Giancarlo Palanti, e discutidos os problemas do desenho dos móveis

${ }^{16}$ TENTORI, Francesco. PM Bardi: com as crônicas artísticas do "L’Ambrosiano" 1930-1933. Trad. de Eugênia Gorini Esmeraldo, São Paulo: Instituto Lina Bo e P. M. Bardi/Imprensa Oficial do Estado, 2000, p. 161. 
no Brasil, atribuídos à omissão dos arquitetos nesta atividade profissional que passa a ser exercida por tapeceiros e madames. 0 texto apresenta o Studio de Arte Palma, dedicado ao desenho industrial desde 1948, como exemplo na busca da coerência entre as características do clima, do material (o estudo das madeiras brasileiras) e da simplicidade estrutural. A afinidade entre esses dois artigos estabelece a "união" dos tempos que fica ressaltada com a seqüência de imagens dos navios "gaiolas" com redes utilizadas para dormir e sentar, as quais inspiraram uma das poltronas desenha por Lina Bo.

A simplicidade e economia de meios, presentes nos móveis populares, são valores que Habitat identifica também em outros aspectos da cultura popular. Desta

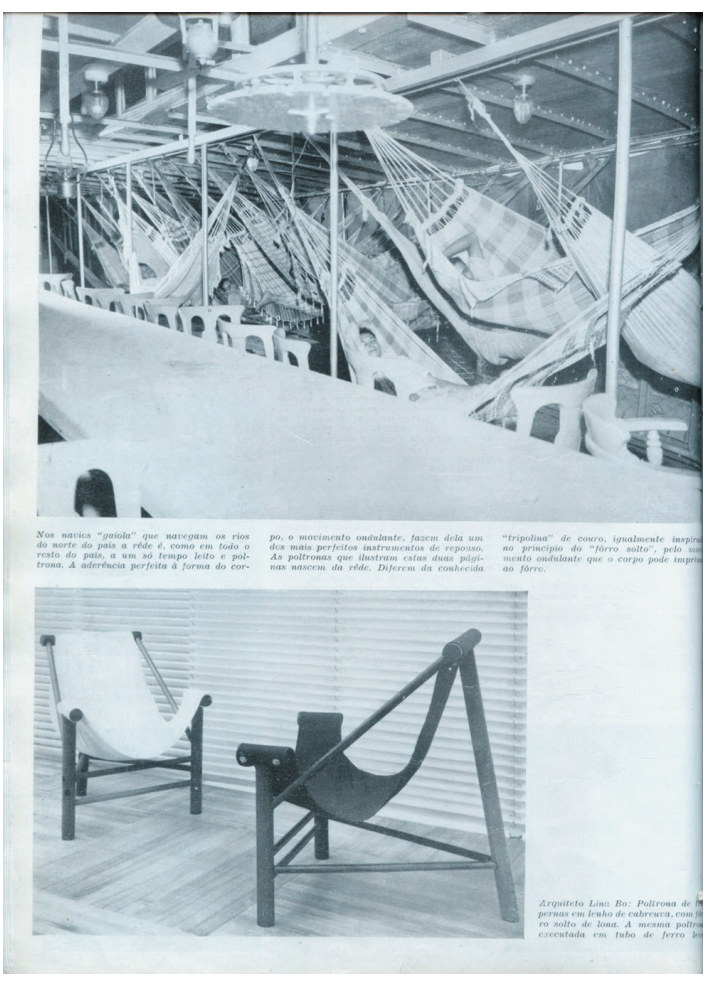

23 e 24 . "Móveis novos" traz a produção do Studio de Arte Palma como exemplar, com desenho e materiais adequados ao clima brasileiro.
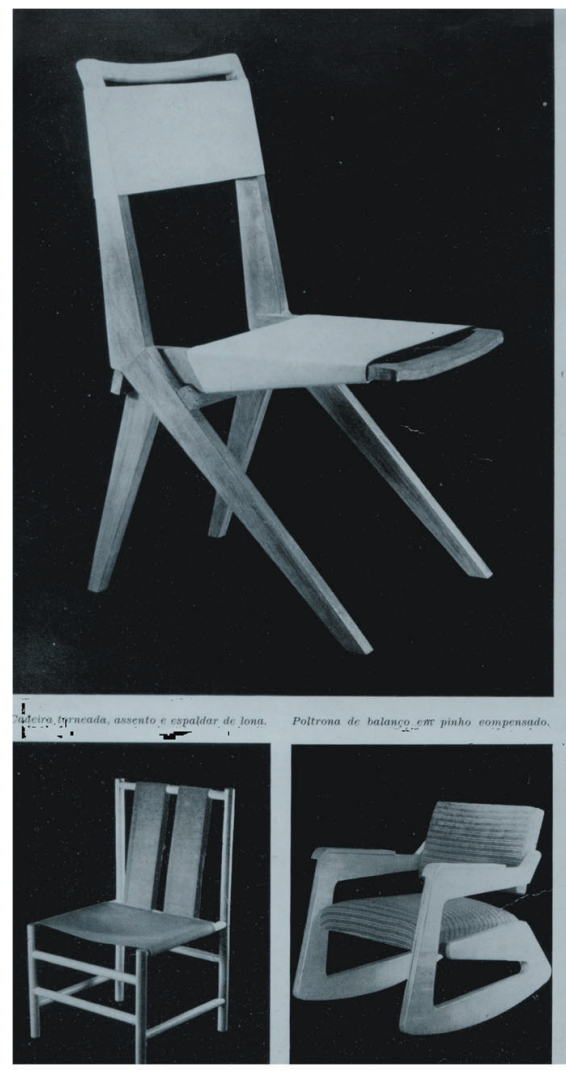

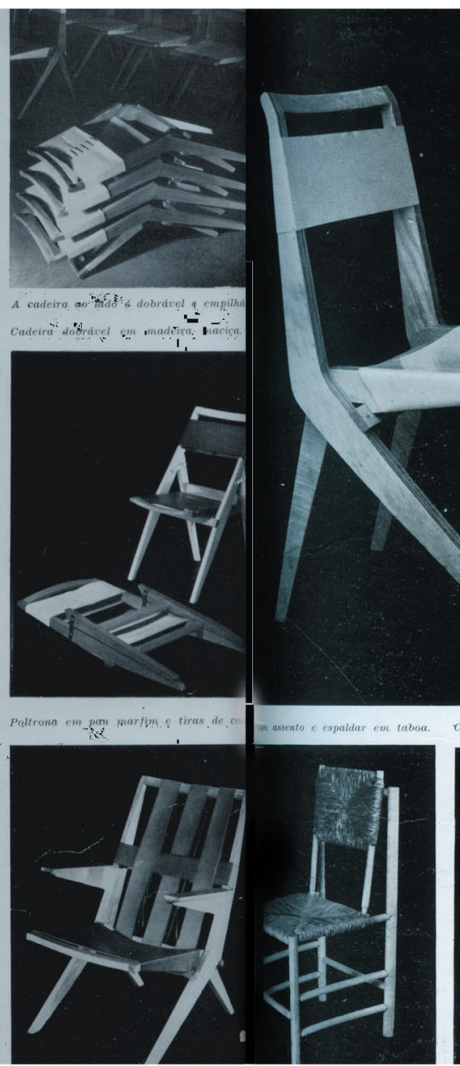

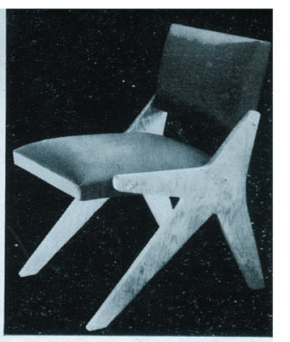
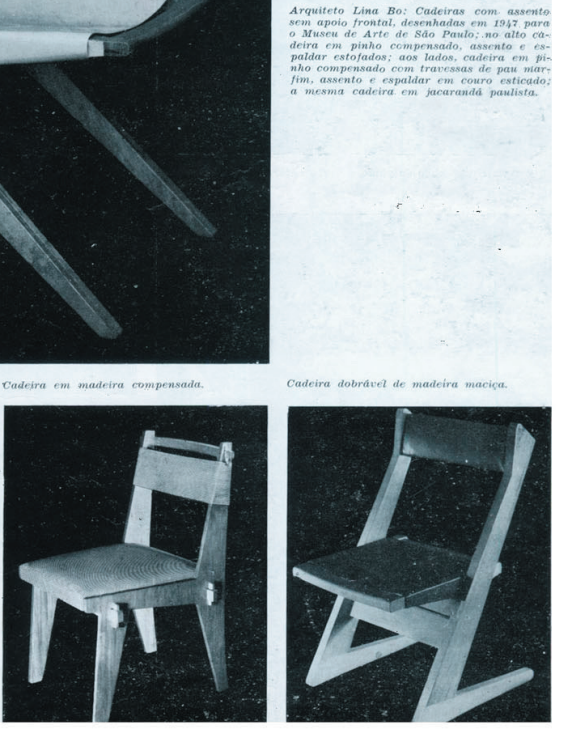


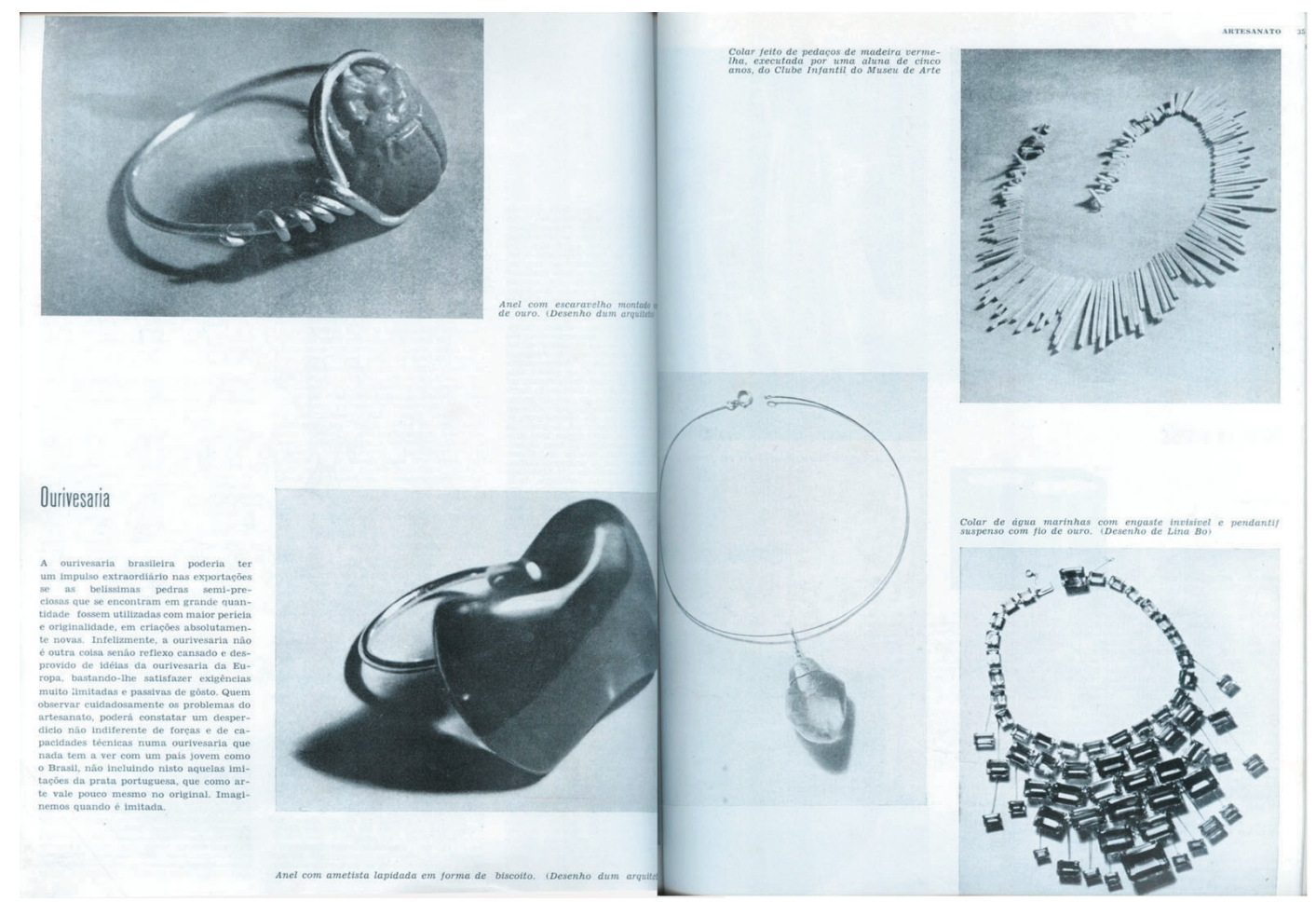

25 . Na busca de incorporar as riquezas e características brasileiras ao universo do design, Habitat aponta as pedras semipreciosas ainda não exploradas, utilizadas em colares desenhados pela arquiteta.

forma tem espaço a arquitetura produzida pelo homem simples do interior do país, autor também de objetos que passam a ser valorizados pela revista e que terão destaque entre as peças do Museu de Arte de São Paulo; todos exemplos para a produção contemporânea.

0 tom irônico emprestado a muitos textos, principalmente os de autoria de Bardi e Lina, marca a seção de "Crônicas de Alencastro", em que a crítica aos costumes, a arte e a arquitetura têm lugar de forma mais apimentada. 0 pseudônimo Alencastro, que em trabalhos anteriores era apresentado como nome utilizado por Lina $\mathrm{B}^{17}$ para entrar em assuntos polêmicos de forma mais "confortável", neste trabalho passa a ser visto ${ }^{18}$ como uma coluna coletiva, possivelmente dirigida por Lina, mas na qual "qualquer um" tinha a liberdade de publicar sua crítica, depoimento ou ponto de vista, desde que pertinente e consoante aos princípios da revista e, portanto, do universo cultural que se propunha.

Logo no primeiro número, "Alencastro" comemora a superação das antigas colchas de retalhos pitóricos, que tomavam o pomposo título francês de "salon", pelas mostras individuais e coletivas realizadas nos museus

${ }^{17}$ Entre os trabalhos que afirmam essa autoria, o livro Lina Bo Bardi, São Paulo: Instituto Lina Bo e Pietro Maria Bardi, 1993,com coordenação de Marcelo Ferraz.

${ }^{18}$ A partir de depoimentos de Flávio Motta e Luis Hosaka dados a esta autora em março de 2006. 
e galerias, como a Galeria Domus. Assim, Habitat anuncia o início de uma nova fase em que tem destaque também a arquitetura nova, como o projeto ganhador do primeiro lugar de um concurso para a nova estação de Belo Horizonte concedido a Ruchti, Croce e Candia. A coluna chama a atenção também para a falta de divulgação de importantes eventos, como a exposição de Le Corbusier realizada no Museu:

“(...) A mostra era um excelente argumento de vivo interesse para São Paulo, mas nenhum dos escritores e jornalistas que se dedicam à divulgação de arte, (sic) publicou uma linha siquer (sic). A explicação disso reside talvez no

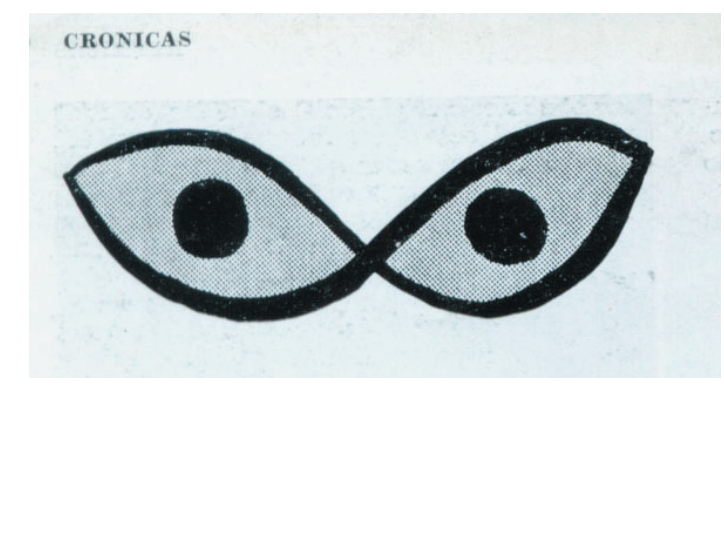

26. Símbolo que indica o início da seção "Crônicas de Alencastro", publicada no final de todas dos primeiros quinze números de Habitat.

fato de que não sabiam o que dizer; seria razoável, pois não é fácil escrever sobre arquitetura sem uma certa preparação técnica. (...)"19.

Também nesta coluna, em que as letras miúdas adensam a diversidade de assuntos abordados, há espaço para a divulgação das atividades do Museu, para "puxar a relha" de alguns artistas, "mandar recados azedos" para a rapaziada e para as senhoras da sociedade e até para a cúria metropolitana:

"A respeito do ultimo campanário de igreja (São Paulo, quanto a campanários não tem sorte), o da Consolação, o que temos a dizer é 0 seguinte: que 0 cimento armado não deveria se prestar a tais brincadeiras sem sentido. E que isto sirva para todos estes mestres de obra que, acreditando, e naturalmente de boa fé, que em São Paulo neva, obstinam-se em construir campanários ponteagudos como os da Alemanha". ${ }^{20}$

Na seção de "Alencastro" é dada ênfase às artes plásticas e à arquitetura, realizando uma cobertura dos eventos, exposições e novidades que vinham acontecendo em São Paulo, como a abertura do MAM. Não pretendemos aqui analisar as crônicas cuja complexidade exige um trabalho em separado, mas apenas revelar que nessas páginas finais das publicações de Habitat permanece o mesmo discurso das páginas anteriores, acentuado o tom no que faltou espaço para "dizer".

A crítica aos que se dizem críticos aparece inúmeras vezes na revista e confirma uma preocupação de Bardi já presente nas páginas de Be/vedere ${ }^{21}$. Aos que saíam na defesa e valorização dos pseudo-artistas: "0 crítico

\footnotetext{
${ }^{19}$ ALENCASTRO. Habitat, São Paulo, no 1, out./dez. 1950, p. 90.

${ }^{20}$ Ibidem, p. 92.

${ }^{21}$ Belvedere foi o periódico editado pela Galeria Bardi S/A, localizada na via Brera em Milão, na qual destaca-se o protesto contra a discriminação burguesa a alguns artistas modernos e contemporâneos não alinhados ao fascismo.
} 


\section{Medidas}

Cuidado, rapazes, não vão dizer que a famosa Semana de Arte Moderna foi um acontecimento mais importante que o Renascimento italiano ou o chamado século de Péricles.

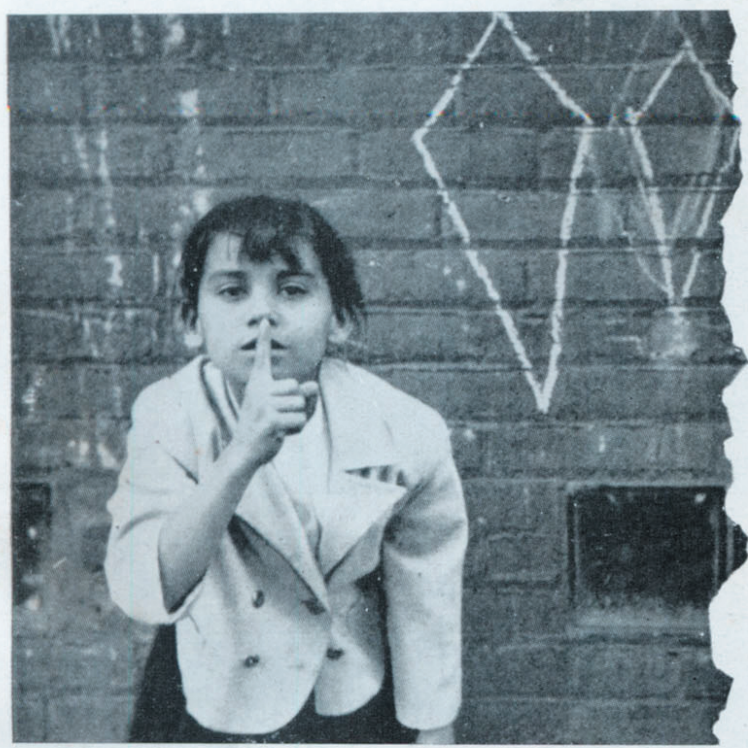

o menino convida os criticos de corda a falarem

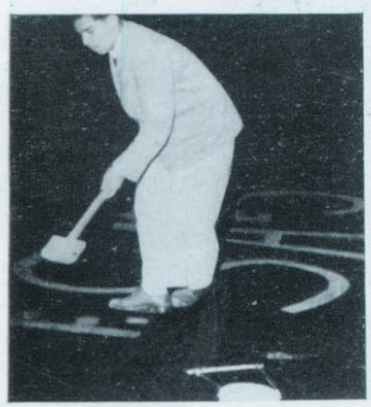

Nossos pintores sociais

\section{Inseticida}

O pintor Almir Mavignier verificou uma vez que certos amarelos de seus quadros matavam moscas instantaneamente.

\section{Questões de lingua}

Um amigo nosso, devotado às questões de pedagogia infantil, contou-nos o seguinte: discutia-se acaloradamente se as poesias infantis deviam ou não ser corrigidas, antes da publicação. O debate era travado com a participacão de adulcom a participacáo de adultos e crianças. Foi quando uma das ultimas indagou. "Isso de corrigir, pode estar muito bem, mas, e quando se tra tar de palavra inventada"?

\section{Flexor}

O popular pintor francês esta expondo na Galeria Oxumare, da Bahia, tendo lá deixado 48 quadros. Belo exemdade confiança na velha cidores de arte.

\section{Prefeitura}

Quando folheamos um catálogo de qualquer grande museu da Europa, principalmente do Louvre, é interessante observar o número de importantes aquisições feitas através dos poderes públicos. Acreditamos que as mais significativas aquisicóes feitas pelo tivas aquisiçoes feitas pelo nosso govêrno, datam do Império. Uma ou outra tela, premiada nos salões oficiais é requerimentos, são esporadicamente incorporadas às galerias oficiais. E uma ideia que parece apavorar os governantes, essa de enriquecer as nossas pinacotecas. Entretanto, é preciso fazer justica, última investidas justiça, ulgovernantes, das nossas câmacas e fenderam o patrimonio artistico nacional, adquirindo o "São Gerónimo" de Mantegna. Foi um magnífico exemplo este da Prefeitura Municipal, do Sr. Armando de Arruda Pereira, do vereador André Nunes e de todos os vereadores de São Paulo. Romperam a inércia que nos estigmatizava por tantas dezenas de anos. Foi além a contribuicão dos governantes da Cidade quando também as inaram, por iniciativa do astãoram, por iniciativa do endes do Amaral, um convênio para proporcionar ao Museu de Arte e a todas as instituitos nossos Cultura Cultura Sr. Nelson Marcon- cỗes culturais de São Paulo, bolsas de estudo, ensino gratuito e facilidades aos estudantes de arte.

Qualquer individuo que deQualquer individuo que demonstra aptidão para as artes tera assim franqueado os curdos com os têrmos do convînio.

\section{Carta anônima}

Certos cavalheiros ocuparam ùltimamente o seu tempo em remeter numerosas cartas anônimas contra os "falsificadores de obras de arte", fechando as missivas com exaltacốes à Bienal, que "teve retacoes a Bienal, que "teve reMas convém esclarecer que Mas convém esclarecer que falsificação, em arte, não consiste exclusivamente no espaco de tela ocupado por falsos "Chabas e Modigliani", de qualquer vira-lata que virou cachorro de raça e banca o grande mestre, o "professor de pintura", mas também, e principalmente, por certa dúbia produção pseudo-intelectualista destinada aos interêsses de uma classe priviterêses de uma clase privilegiada, uma producão ignorante da realidade contemporanea, que visa apenas o proveito proprio, baseada no equivoco, não escolhendo caminhos, adulterando aquele meio sagrado e tipicamente coletivo de comunicação entre os homens, que é a arte. Sim senhores, colaboramos com a Delegacia de Falsificaçôes, comecemos denunciando todas as obras de arte dos "solitários", dos habitantes das "torres de marfim", dos "decorados" da arte, dos "pompiers" e exibicionistas do faiso modernismo dos capitalistas da arte, cairdos capitalistas da arte, causas de nossas mais amplas repercussão mundial".

\section{Aplausos}

Estamos habituados a ver nas manchetes dos jornais, à propósito de câmaras municipais, a notícia de que o vereador Fulano acertou um bofetão no olho esquerdo de um nobre colega, que Beltrano declarou da tribuina que não faz um juizo muito lisongeiro das virtudes da progenitora de Sicrano, outras alegres ocupacōes no gênero. Os nossos plausos, portanto, à Câmara de Vereadores de Santos, quando lembra o nome do pintor caicara Emido de Soua, natural de Itanhaem, que, apesar de ter falecido aos oitenta e dois anos, não chegou a ver seu nome apontado como um dos mais expressivos da pintura popular brasileira. A notícia de jornal acrescenta ter partido a iniciativa do vereador Silvio Fortunato, que também apresentou projeto tamben apresentou projeto dio de Souza a uma rua de Santos, alem de sugerir a Prefeitura a organização de

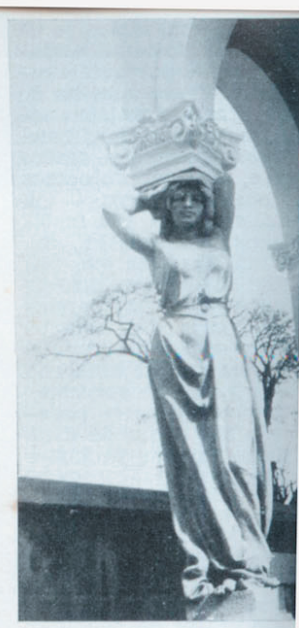

Famosa escultura" na Paulista que continua, descanco, a sustentar un

uma exposição de suas por ocasião do terceir versário da morte do a 19 de setembro pr Muito bem!

\section{Bahia}

Um nosso redator foi alguns dias na Bahia, finalidade de preparar rial para um nume Habitat, dedicado à cidade. $\mathrm{O}$ número em tão será oferecido aos res públicos que deixa manchar pouco a po manchar pouco a po nais obstante os esfor nãontes do Serviço de gentes do Serviço de

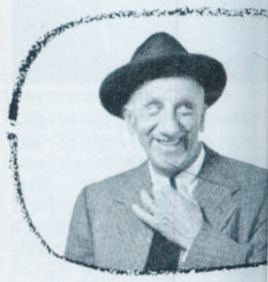

Amador de arte diante pintura que represen riachuelo iluminado $p$

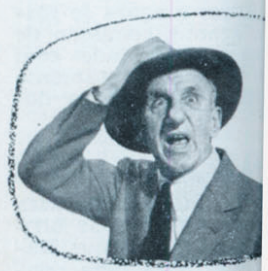

o mesmo diante de tura de Picasso 
improvisado é tão danoso quanto o pseudo-artista [...]. Tais escritores e escritorezinhos são os autores do interminável romance de opiniões sobre a arte atual que o público vai folheando". Contra a situação vigente a revista assume 0 compromisso de dar um importante passo na constituição de uma documentação crítica dos diversos setores da arte brasileira.

Há também em Habitat uma preocupação especial com o projeto gráfico da revista, que traz uma forte influência das experiências anteriores de Lina na Itália onde desenvolveu atividades como ilustradora e editora. Um olhar rápido sobre as páginas da revista Domus pode acusar a semelhança entre a apresentação gráfica da nossa revista e a da italiana. Também é possível notar em Habitat a preocupação em assimilar as diferentes linguagens que apresenta; assim, o tratamento dado para os artigos relacionados à fotografia não é o mesmo que o direcionado a arquitetura ou as artes plásticas. A quantidade de vazios, o corpo do texto, o destaque dos títulos e assuntos, a dimensão e o número de imagens e ilustrações, a forma como aparecem, são alguns dos elementos que variam conforme 0 assunto e revelam uma preocupação não apenas com a mensagem, mas com o meio que a está levando. Há aí claramente um entendimento de que o meio é a mensagem e, portanto, um discurso moderno não poderia prescindir de uma revista com o mesmo espírito.

Os diversos temas que a revista se propõe a debater aparecem na publicação em uma seqüência e com um peso que denota a "preferência" pelos assuntos relacionados a arquitetura e as atividades ligadas ao Museu de Arte, o que no entanto não desmerece os demais, ao contrário, torna possível um panorama conjunto que revela a efervescência do período e a afinidade de pensamento que moviam todo esse universo cultural.

A partir da análise dos periódicos identificamos uma estrutura recorrente nas quinze publicações: um conjunto de páginas no início e no fim dedicado à publicidade, os quais "emolduram" outro conjunto que com exceção de duas publicações ( $n^{0} 6$ e $n^{0} 7$ ) parte de artigos dedicados aos grandes temas: primeiro a arquitetura, depois as artes plásticas, seguidas finalmente por um importante pot-pourri de assuntos ligados a cultura que antecedem a seção de "Crônicas de Alencastro". Na seção voltada à cultura estão sempre presentes artigos dedicados ao cinema, à fotografia, ao teatro, à dança e à música, em que são pautadas questões relativas ao desenvolvimento da cultura nacional, como a Companhia Cinematográfica Vera Cruz, por meio de textos de Alberto Cavalcanti e Florentino Barbosa e Silva.

Essas seções apresentam o universo da produção local, apontando aspectos da música e dos costumes brasileiros, como o folclore e a capoeira e a "revelação" do interior do Brasil; aspectos que passam a ser 
incorporados às diversas linguagens e produções que a revista publica em artigos com caráter crítico e educativo. Essa coluna também divulga as iniciativas do museu nos mais diversos setores, por meio de cursos e eventos que promove com a colaboração de importantes profissionais, como Yanka Rudzka na dança e Ruggero Jacobbi no cinema.

Habitat se propõe ainda a registrar em suas páginas desde artistas consagrados, como os arquitetos do Ministério da Educação e Saúde e Aleijadinho, até as belezas anônimas, como a cabana de pau-a-pique e um pote marajoara. Desta forma aponta o interesse pela transformação da paisagem do país, pelas artes populares, pela arquitetura moderna e suas características "tropicais".

Durante o período estudado, tem destaque também nas páginas da revista a "descoberta" de uma produção nacional com características locais, especialmente a cultura popular do Nordeste, o que fundamenta 0 desenvolvimento de um projeto de modernidade atribuído de identidade e autenticidade que já marcara os primeiros anos do modernismo, quando os artistas e intelectuais saíram em busca de elementos para construir uma imagem que afinal desse sentido ao Brasil moderno.

A revista Habitat, graças ao olhar de Lina Bo, desde o principio alterou e elevou o status dos objetos populares, frutos de uma produção artesã, ao atribuir-Ihes valor artístico. 0 mesmo fez com os objetos de uso cotidiano saído da prancheta dos industrial-designers, ao colocá-los na "vitrina das formas" no Museu de Arte lado a lado a objetos de relativo valor histórico. Expostos em uma grande vitrina com paredes de cristal que dividiam no MASP as exposições permanentes das exposições periódicas, o museu pretendia um sentido museológico a esses objetos corriqueiros, verificados nas imagens publicadas em Sinopse do Museu de Arte onde coabitam uma máquina de escrever "Olivetti", um tronco de árvore corroído pelo mar, um pote de massa de tomate e vidros romanos.

"(...) A maioria das pessoas costuma encarar a forma com certa indolência visual, isto é, com falta de discriminação ou espírito de comparação, quase sempre sem nenhuma preocupação crítica, adquirindo um copo ou um aparelho de rádio, uma máquina de costura ou um vaso, sem consciência da importância e da responsabilidade que a entrada de uma nova forma representa para o lar. Verdade é que na maioria das vezes a própria arquitetura da casa obedece à mesma confusão de valores e de gosto. Esta exposição visa portanto despertar a atenção sobre: proporção, racionalidade, inteligência, gosto, arte, historicidade, de toda e qualquer forma com a qual se entre em contato."22

22 "Vitrina das Formas", Habitat, São Paulo, nº 1, 1950, p. 35. 

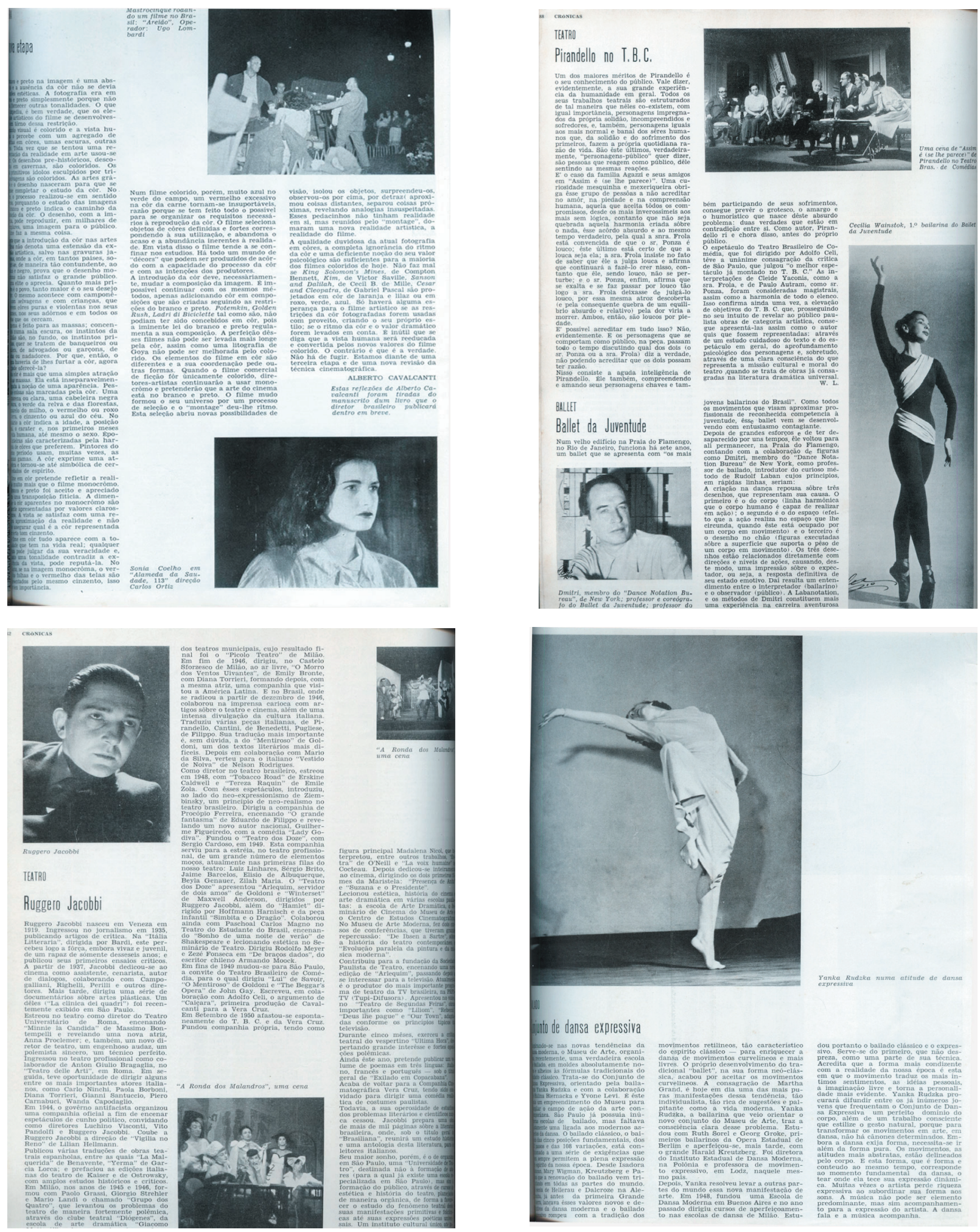

TEATR

Ruggero Jacobbi
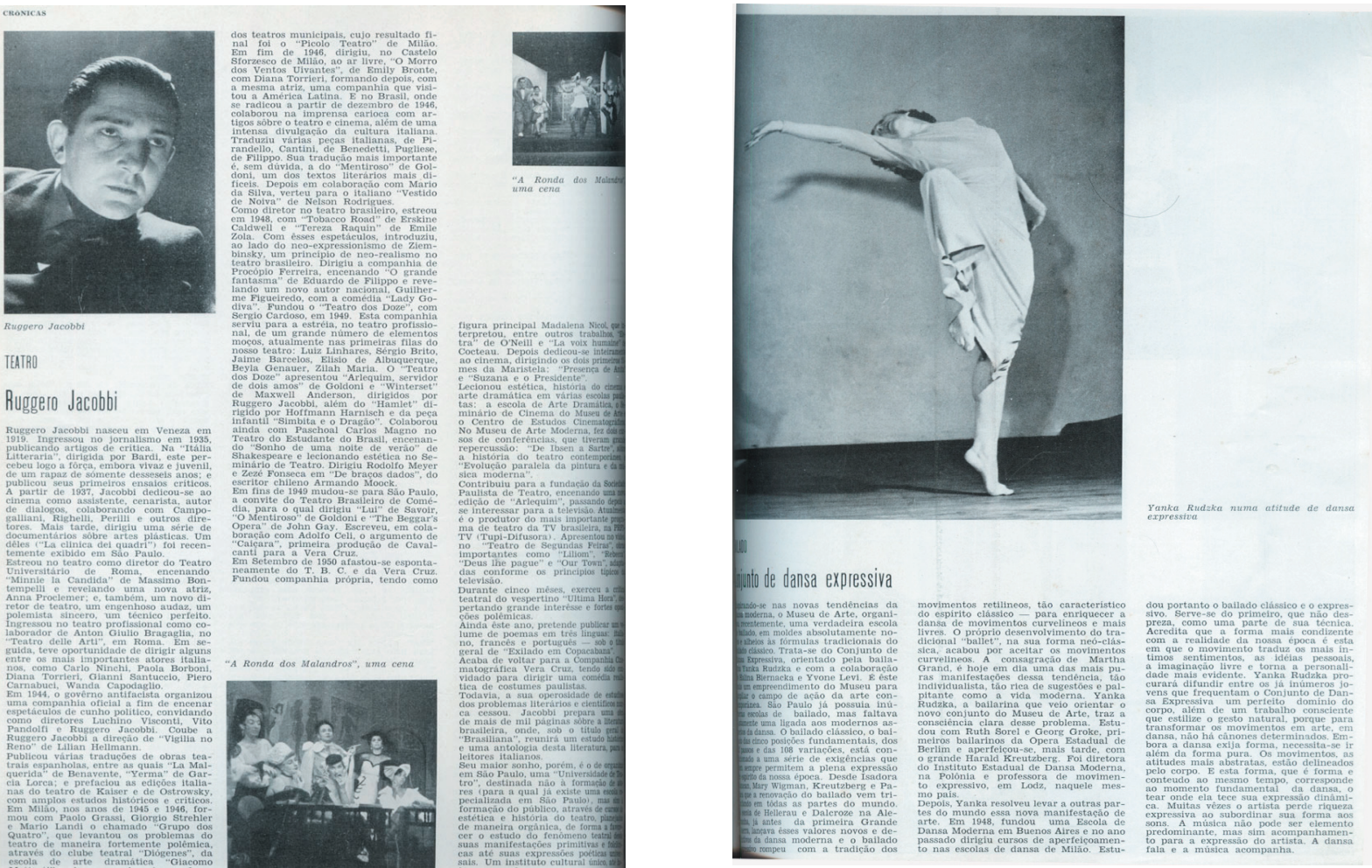

Delineando 0 desenvolvimento cultural nacional, Habitat dedica as últimas páginas que antecedem as "Crônicas de Alencastro". 28 . "A nova etapa", escrito por Alberto Cavalcanti, antecipa reflexões de um livro a ser publicado sobre 0 cinema no Brasil. 29 . Ao teatro "Pirandello no T.B.C." faz uma crítica positiva a montagem de "Assim é (se lhe parece)". 30 . "Ruggero Jacobbi" traça o percurso do destacado diretor e crítico de teatro e cinema e noticia sua volta a Vera Cruz. 31. "Conjunto de dança expressiva" divulga o curso no MASP de Dança Expressiva, ministrado por Yanka Rudzka. 

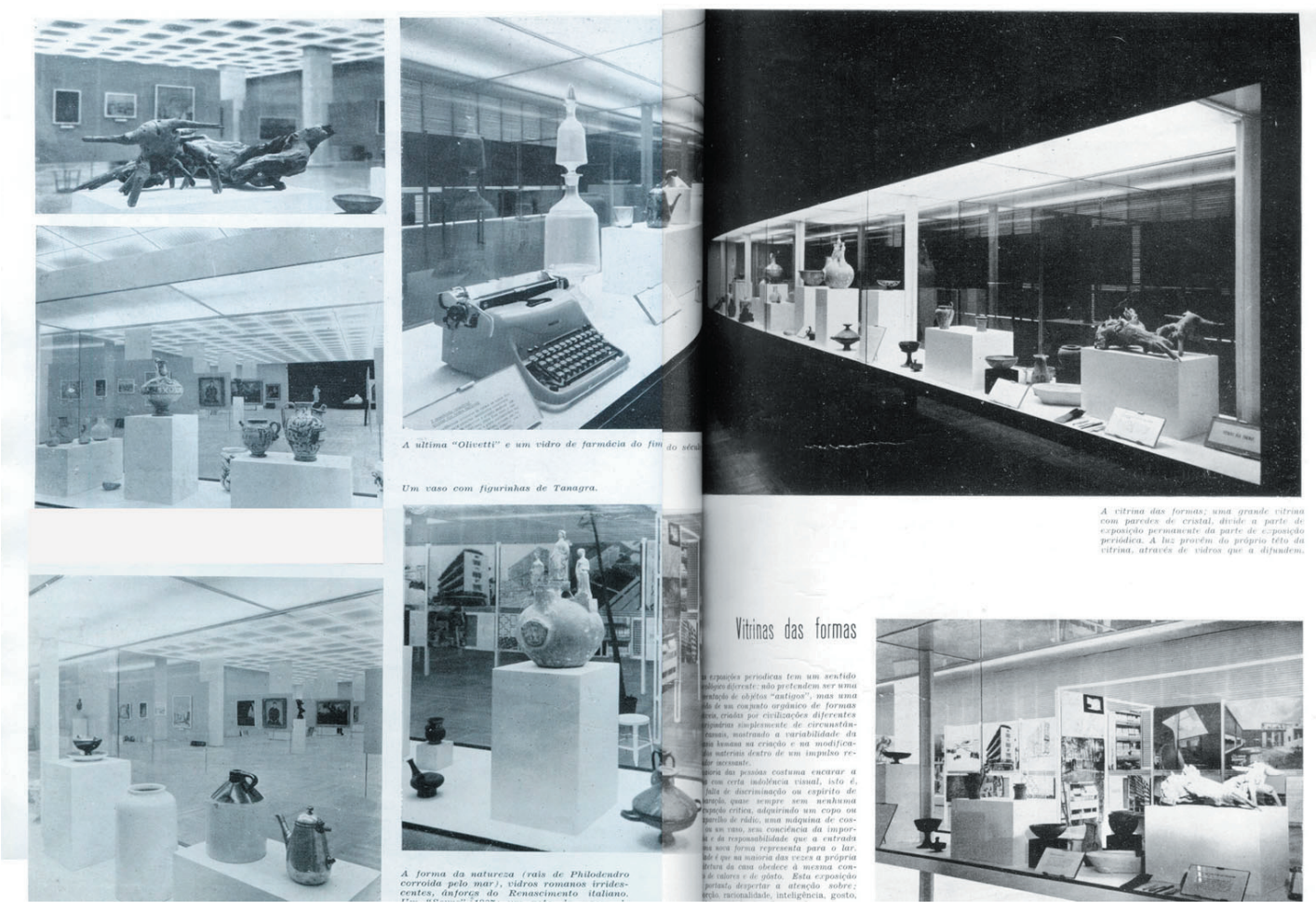

32. Páginas que ilustram a "Vitrina das formas" do MASP, fazendo a apologia ao bom desenho dos objetos.

A preocupação com o campo do desenho industrial levou o Museu a fundar, como já mencionamos, o IAC. Instituto com o qual Habitat se alinha no mesmo desafio ao divulgar os profissionais ativos neste campo de produção e a "panfletar" seus objetivos e atividades:

"É mais importante para um país possuir um bom projetista, capaz de criar e de executar um bom selo, do que aqueles artistas grandíssimos e puros, capazes de inventar um mundo de coisas. Interessam a uma nação os bons criadores de etiquetas de cerveja, caixas de fósforo, abecedários, anúncios publicitários, uma cadeira, um copo, um tecido, etc. (...) (mas) o gênio nasce e frutifica somente num clima adequado, numa atmosfera produzida mediante as contribuições da cultura duma época e dum lugar.

(...) Lemos por isso, com vivo prazer as seguintes palavras no folheto de propaganda do 'Instituto de Arte Contemporânea':

'Formar jovens que se dediquem à arte industrial e se mostrem capazes de desenhar objetos nos quais (sic) 0 gosto e a racionalidade das formas correspondam ao progresso e a mentalidade atualizada;

Aclarar a consciência da função social do desenho industrial, refutando a fácil e deletéria reprodução dos estilos superados e do dilentantismo decorativo.

Ressaltar o sentido da função social que cada projetista, no campo da arquitetura aplicada, deve ter em relação a vida'.(...)

Criticar não adianta. Precisa-se lançar as bases para um novo espírito, para o novo clima, e é neste sentido que se está trabalhando. 'Habitat' sentir-se-á satisfeita em anotar e divulgar todos os esforços informados por este intuito" 23 .

${ }^{23}$ ALENCASTRO, Habitat, São Paulo, nº 1, 1950, p. 94. 
Com o mesmo olhar, no campo da arquitetura são apresentados projetos seguidos de textos em que figuras nacionais e internacionais discutem questões diretamente ligadas à produção moderna, com atenção especial aos projetos que resgatam usos e materiais locais ou mesmo que respeitam as condições culturais e físicas do país. Logo no primeiro número Habitat divulga a arquitetura moderna realizada no Brasil, escolhendo como primeiro protagonista Vilanova Artigas, que tem seus projetos de residência publicados e nos anos seguintes irá ocupar papel importante no cenário da arquitetura paulistana.

Essa arquitetura, que em Habitat é inserida no campo da cultura, terá papel de destaque entre os assuntos apresentados pela publicação e neste trabalho terá atenção especial. Dedicaremos o próximo capítulo à compreensão e análise dessa arquitetura eleita, divulgada e discutida pela revista.

Com este trabalho foi também possível identificar que em alguns momentos a revista dedica números especiais a temas considerados prioritários e que vem problematizados: a revista $\mathrm{n}^{0} 2$ é dedicada a defesa dos valores da arquitetura moderna brasileira; a $n^{0} 4$, um número especial sobre a produção do Convênio Escolar; e a revista $n^{0} 13$ enfoca as atividades do Museu de Arte de São Paulo.

Motta chama a atenção para a edição $n^{0} 13$ (outubro/dezembro de 1953), que por sua intervenção direta transformou-se no "especial" sobre as exposições internacionais do acervo do Museu de Arte de São Paulo, reunindo um conjunto de artigos em torno deste tema. Logo na primeira página, o editorial, "0 Museu de Arte de São Paulo", divulga o artigo escrito por Germain Bazin para o Arts que discorre sobre o sucesso da exposição no Musée de l'Orangerie de Paris. Logo após, "0 valor intrínseco do que está sendo apresentado em Paris", assinado por Assis Chateaubriand, declara sua decepção à recusa de pessoas ilustres ao convite de acompanhá-lo à Paris para o evento, reclama a falta de atenção dada às artes no Brasil e chama a atenção para o reconhecimento europeu perante 0 acervo do Museu. Segue ainda "Os quatro Nattier", anunciando as novas aquisições do Museu ${ }^{24}$, desta vez destaca a reivindicação pela França de permuta dessas obras, 0 que denotaria seu valor. Em "Um milagre brasileiro apaixonou Paris", Claire Gilles Guilbert acentua a magnitude do acervo brasileiro, colocando-o como um verdadeiro acontecimento na capital francesa e destaca a importância da iniciativa de Assis Chateaubriand, suas qualidades empreendedoras, e a fundamental colaboração do casal Bardi no que diz respeito a curadoria e ao projeto da sede.

0 último texto deste "número especial" de Habitat, sem autoria e título, apresenta o sucesso do evento como

${ }^{24}$ Seção habitual de Habitat em que são apresentadas as novas aquisições da Pinacoteca do Museu de Arte de São Paulo. 

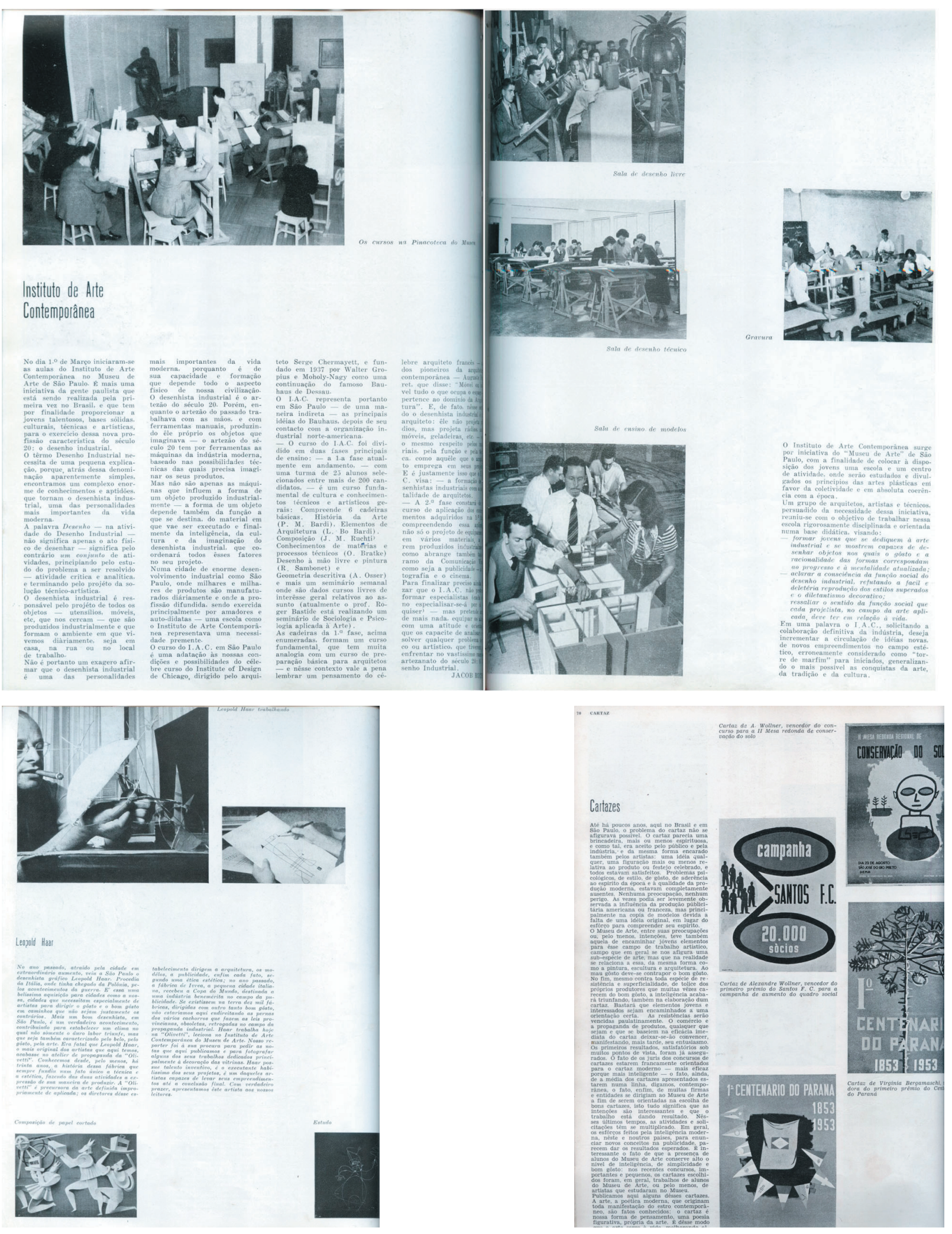

33. Um entre tantos artigos de Habitat que divulga as atividades e objetivos do Instituto de Arte Contemporânea (IAC). 34 . 0 designer italiano "Leopold Haar", vindo para trabalhar na Olivetti, leciona no IAC um curso de desenho industrial. 35. "Cartazes" destaca o MASP e o IAC na formação de talentos como Alexandre Wollner, Virgínia Bergamaschi. 

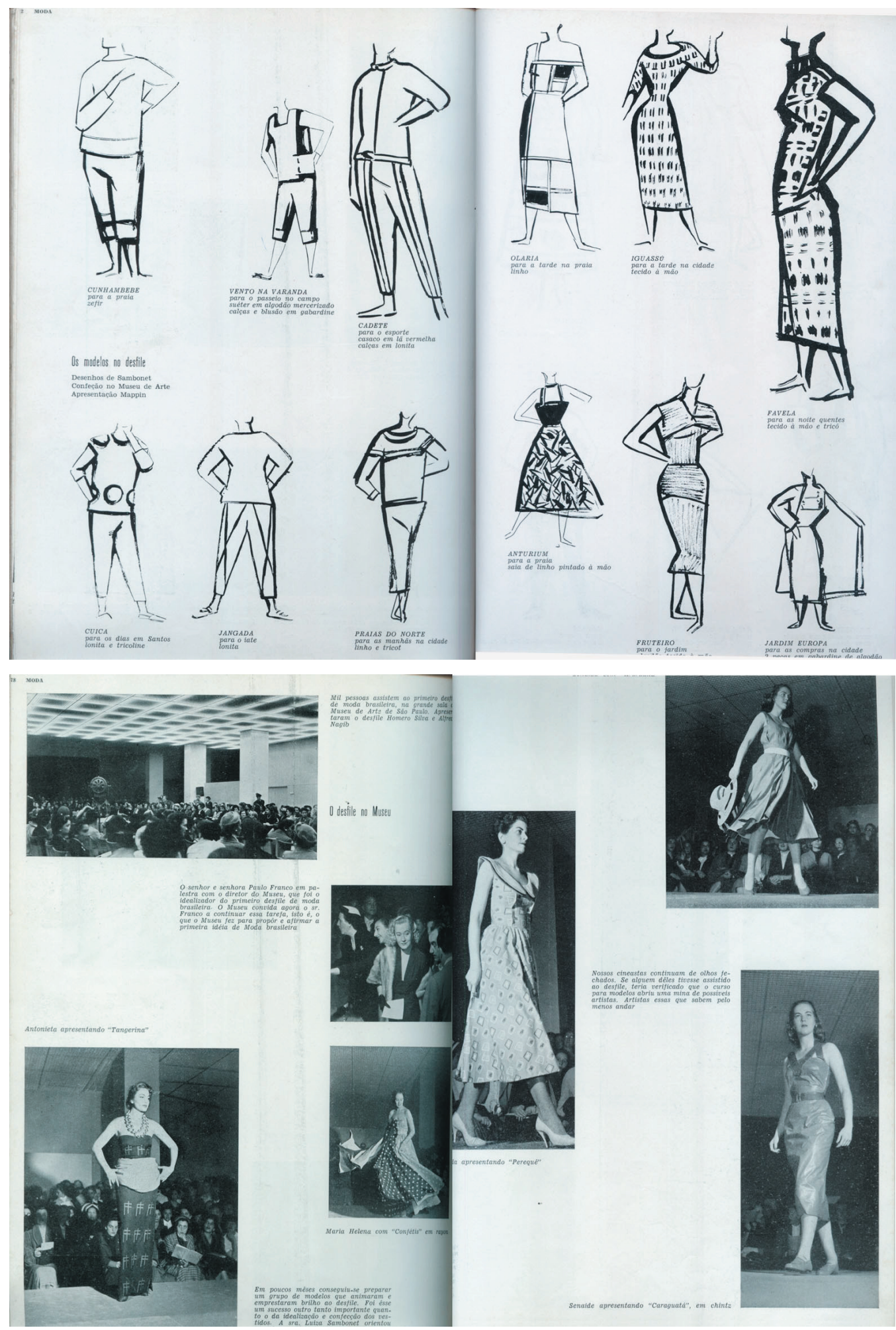

Entre as diversas atividades promovidas pelo MASP, Habitat $n^{0} 9$, destaca em um conjunto de artigos as relacionadas a moda, divulgando o curso para modelo, de tecelagem, estamparia, e outros. 36 . "Os modelos no desfile" exibem os desenhos de figurinos desenhados por Sambonet a serem confeccionados pelo MASP e apresentados no Mappin. 37 . Fechando as "homenagens" a moda brasileira, "0 desfile no Museu" divulga as imagens do primeiro desfile de moda brasileira realizado na sede do Museu. 
resposta aos que "desestimularam" a iniciativa do Museu de levar seu acervo a Paris, colocando em dúvida sua autenticidade e significado. 0 texto também chama a atenção às atividades "efervescentes" do Museu expostas no l'Orangerie, entre os quais o autor cita a revista Habitat, o que "oficializa" ainda mais a ligação destas instituições ${ }^{25}$. Uma imagem do evento estampada nas páginas de Habitat ilustra os objetos expostos: obras de arte consagradas, painéis e vitrines com as atividades do MASP, os diversos cursos e palestras realizados, fotografias e trabalhos deles resultantes e exemplares das revistas Habitat já publicadas.

A presença de Flavio Motta no "intervalo" de quatro edições coincide com a ausência do casal no Brasil durante 1953, ano em que Lina e Bardi viajam à Europa acompanhando o acervo da Pinacoteca do MASP que neste momento são "emprestadas" a importantes e consagradas Instituições européias, como Musée de l'Orangerie de Paris, a fim de conquistar crédito internacional e assim provar a autenticidade das obras do acervo que colocavam em risco o futuro da instituição. A dúvida levantada contra "sua" Pinacoteca fez com que Pietro organizasse uma caravana a fim de, a partir da valorização e reconhecimento do acervo pelas instituições

${ }^{25}$ Apenas a partir da década de 90 é que o MASP terá um boletim oficial, o "Mensageiro de Arte"; mas antes dele, no início
dos anos 70 Bardi criou e dirigiu o "Mirante das artes", revista com o mesmo nome da nova galeria de Bardi, que dirigiu
paralelamente ao Museu. A revista da galeria passou então a ocupar o espaço deixado por Habitat quase dez anos antes.

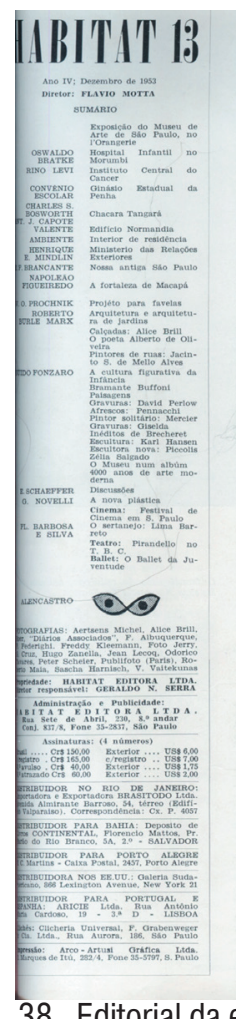

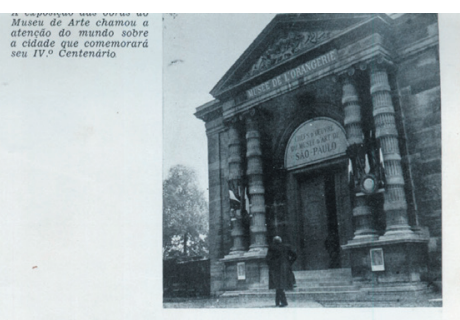

0 Museu de Ate de São Paulo no l'Orangerie

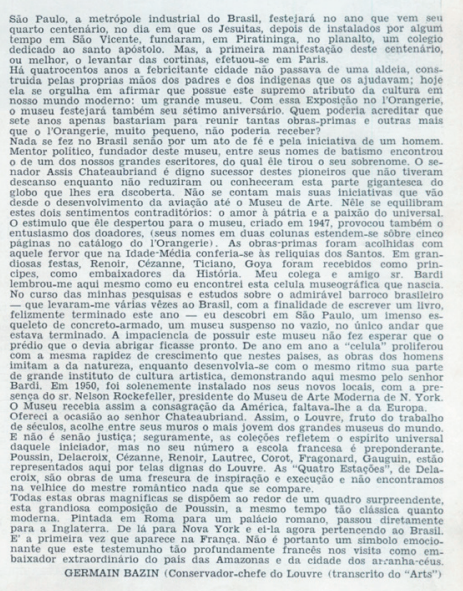

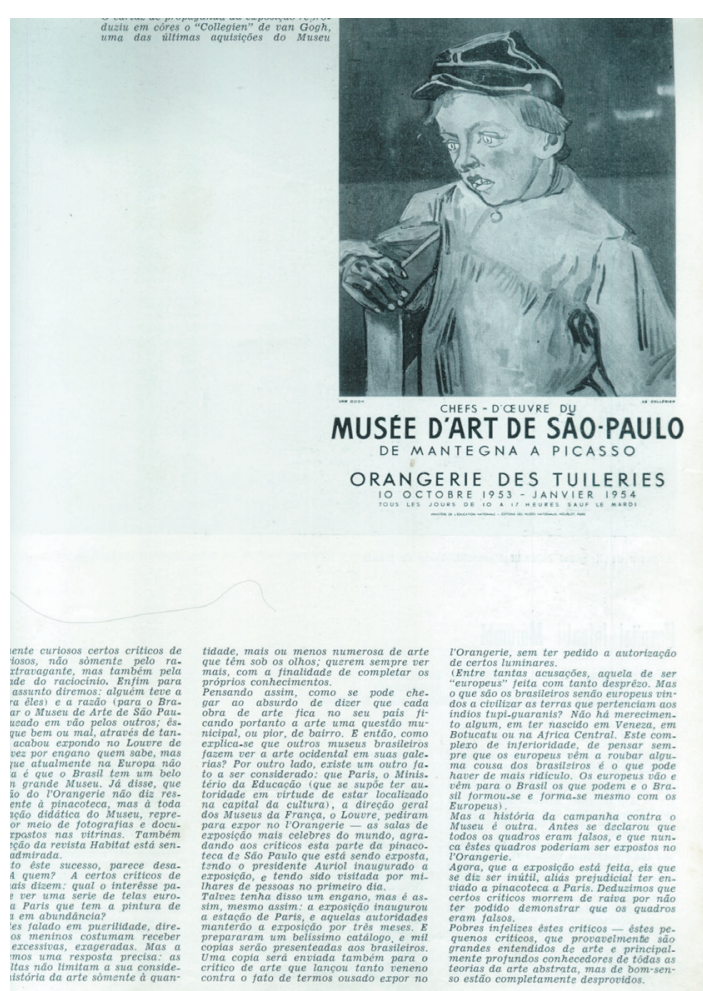

38 . Editorial da edição de $n^{0} 13$ que traz um conjunto de artigos sobre o "empréstimo" do acervo da Pinacoteca do MASP para instituições européias. 39 . A crítica internacional publicada em Habitat para certificar a autenticidade do conjunto do seu acervo e valorizar as atividades desenvolvidas no museu. 
consagradas, desbancar qualquer calúnia ao tesouro que conseguira reunir em São Paulo²6.

Por meio de depoimentos recolhidos ${ }^{27}$ com Flávio Motta e Luis Hosaka, sempre houve uma quantidade razoável de textos já prontos para ser publicado nas edições futuras de Habitat, o que não deixou de acontecer quando o casal saiu de viagem. Sendo assim, cabia ao diretor, neste caso Flávio Motta, organizá-los, paginar adequadamente e preencher os "vazios" que possivelmente iriam aparecer, e desse modo honrar o compromisso da revista.

Desta forma, nos tempos de "ausência" de seus idealizadores Habitat é a mesma revista, com os mesmos colaboradores e continua apontando para a mesma direção. Assim consolida seu importante papel ao colaborar para a discussão das artes e da cultura no país, estabelecendo interlocução entre os diversos campos de produção e diferentes períodos históricos, além do debate entre a produção local e a internacional.

Confirmando a importância da revista no período em que esteve em circulação, temos a declaração dada pelo professor Julio Katinsky de que "(...) a revista Habitat foi um choque para todos nós, muito mais que as Bienais (...)" e que "eles" esperavam ansiosos por cada número e liam até as notinhas de "Alencastro" ${ }^{28}$.

Outro depoimento, dado pelo pintor Cássio M’Boy ao Museu Lasar Segall, acena neste mesmo sentido ao declarar que a divulgação de seu trabalho nas páginas da revista em um artigo assinado por Pietro Maia Bardi legitimou sua produção. 0 pintor assume 0 receio que sentiu antes da publicação de haver uma má repercussão da matéria, o que logo após se inverteu. Declara: "0 Brasil todo viu e disse: 'assim também eu faço'. E o Brasil fez." ${ }^{29}$. Durand chama a atenção para a credibilidade de Habitat ser tributada a quem estava neste momento à frente de sua direção: 0 organizador do que se apresentava como o maior e mais importante museu do continente, transformando-a num termômetro para as discussões e baliza instantânea para tudo ali publicado.

\footnotetext{
${ }^{26} \mathrm{~A}$ facilidade de comprar obras de arte neste momento devido aos baixos preços do pós-guerra e a falência das instituições européias, unido ao extensos conhecimentos na área de mercado e de história da arte de Bardi, tornou possível ao MASP a formação de um dos mais importantes acervos da América do Latina, com obras de grandes mestres, como Rafaello, Tintoretto, Pablo Picasso, Van Gogh, Paul Gauguin, Renoir, Monet, Paul Cézanne, Edgard Degas, Edouard Manet, Bellini, William Turner, entre outros.

${ }^{27}$ Ver transcrição do depoimento de Flávio Motta e de Luis Hosaka dada a esta autora em abril e março de 2006. Anexo 3

${ }^{28}$ Declaração dada pelo Prof. Julio Katinsky, por ocasião da apresentação da dissertação de mestrado de Ethel Leon, a qual coube a orientação no desenvolvimento do trabalho que trata do papel do IAC na formação do campo do design gráfico no país. 0 comentário sobre a importância da revista Habitat foi colocado no contexto de o Museu (MASP) ser um fato novo para os país. (28 de setembro de 2006), Faculdade de Arquitetura da Universidade de São Paulo.

${ }^{29}$ Em nota, DURAND (1989), op. cit., p. 113.
} 
Em 1954, Habitat considera terminada a "fase experimental e de incertezas". Neste mesmo ano Lina Bo Bardi e Pietro Maria Bardi se afastam da revista, justificando-se pelo aumento de trabalho com a preparação dos novos planos do MASP. Entretanto, alegam também que a polêmica que travam na revista não poderia mais ter continuidade, pois, com o tempo tornar-se-ia monótona e repetitiva ${ }^{30}$.

${ }^{30}$ EDITORIAL. Habitat, São Paulo, nº 12, set. 1954. 


\subsection{A experiência italiana de Lina e Bardi e a revista Habitat}

Fundamental para a compreensão da revista Habitat, é conhecer as experiências profissionais anteriores realizadas pelo casal Bardi e o ambiente em que estiveram envolvidos na Itália antes de sua chegada ao Brasil. Vistos como seus idealizadores e principais responsáveis pelas características e pelas questões que Habitat irá abordar e muitas vezes polemizar no período a que este trabalho se dedica, será construído aqui, de forma "interessada", o percurso realizado por Pietro Maria Bardi e Lina Bo Bardi no período que antecede a fundação do MASP e a fixação do casal na cidade de São Paulo. Nesta "construção" muitos fatos serão omitidos em razão de não ser o objeto deste trabalho a análise de indivíduos, mas da revista Habitat, fruto da conjunção de pessoas certas, no momento e lugar certos.

Bardi e Lina aparecem aqui como os inventores de Habitat e seus principais realizadores no momento de seu nascimento. Esta "paternidade" os levou a exercer o cargo de diretoria na revista em seus primeiros anos de circulação, imprimindo a ela características próprias, algumas que permaneceram ao longo de sua vida e outras particulares que fazem dos primeiros quinze números o período a que esse trabalho se propõe a analisar. Vendo Habitat como uma extensão do projeto moderno de Lina e Pietro, já iniciado com a implantação do MASP e dos cursos ali promovidos, serão aqui destacadas as atividades editoriais que Lina e Bardi desenvolveram na Itália e que determinaram ou caracterizaram as particularidades que Habitat apresenta.

As informações aqui reunidas em torno de Pietro Maria Bardi, principalmente durante o período em que permaneceu na Itália, foram extraídas do livro de Tentori ${ }^{31}$. Sobre Lina Bo, a principal fonte de pesquisa foi a dissertação de mestrado de Campello ${ }^{32}$. Outras fontes consultadas serão citadas no momento em que se fizer uso de suas informações.

Como um jornalista comprometido com a causa pública Bardi sempre cumpriu uma liderança intelectual ao exercer seu trabalho crítico nos periódicos italianos, e no convívio com artistas, arquitetos e intelectuais. Entre as inúmeras atividades que veio a realizar no Brasil, a mais longa e na qual seu comprometimento fica latente, foi a direção e organização do Museu de Arte de São Paulo, o qual contou com a revista Habitat na divulgação

\footnotetext{
${ }^{31}$ TENTORI (2000), op. cit.

32 CAMPELLO, Maria de Fátima. Lina Bo Bardi: as moradas da alma. São Carlos, 1997. Dissertação (Mestrado) Departamento de Arquitetura e Planejamento, Escola de Engenharia de São Carlos, Universidade de São Paulo.
} 
de suas atividades e na difusão do mesmo espírito moderno e transformador que movimentou a sociedade paulistana nos fins dos anos 50. Bardi que aparece oficialmente em Habitat apenas nos números 14 e 15 como co-diretor junto com Lina, tem presença constante como colaborador e autor de diversos artigos relacionados a arte e a arquitetura; papel já exercido com brilhantismo na Itália quando, na defesa e divulgação da arquitetura racionalista italiana, dirige e colabora com importantes revistas e jornais.

Pietro Maria Bardi teve, segundo seus relatos, formação autodidata e cedo se inicia no meio jornalístico. Já em 1923 trabalha na redação do Popolo de Bergamo, ocupando-se dos assuntos relativos a arte, geografia, crônicas locais e esportivas. Mas é um furo de reportagem ${ }^{33}$ que o faz mudar-se no início de 1924 para Milão para trabalhar no jornal Secolo, e mais tarde na redação do Corriere della Sera, o qual deixa após uma discussão com o diretor Ugo Ojetti, que the rende um fundo com o qual adquire uma galeria na via Brera, inaugurando aí suas atividades como marchand e crítico de arte.

A já apontada intensa relação entre a revista Habitat e o Museu de Arte de São Paulo tem precedentes no histórico de Bardi, que na Itália por diversas vezes dirigiu paralelamente instituições e periódicos a elas vinculadas. A realização de publicações a fim de divulgar as atividades que promove em suas galerias data de 1927, quando na Galleria Micheli, Bardi passa a editar catálogos das exposições ali realizadas. Prática que, com as devidas proporções e adaptações, vemos anos depois ser repetida na revista Habitat, que além de dedicar amplo espaço para a divulgação das atividades do MASP, alinha-se ao perfil da instituição colaborando na formação de uma sociedade verdadeiramente moderna. Este lugar ocupado por Habitat permanecerá vago por pelo menos dez anos após a saída do casal Bardi da revista em 1954. Somente em 1965, aparecerá um "substituto", a revista Mirante das Artes, revista oficial da Galeria particular de mesmo nome que Bardi passa a dirigir naqueles anos e que, a exemplo das atividades exercidas pelo próprio diretor, vincula-se ao MASP na divulgação de suas atividades e ideologias.

Entre as empreitadas editoriais de Bardi na Itália com perfil semelhante, podemos destacar o periódico Belvedere, iniciado como um boletim da nova Galleria Bardi S/A e depois transformado, a partir de maio de 1929, em um jornal de arte de grande formato ${ }^{34}$ que trazia ao público a "informação necessária" e qualificada

\footnotetext{
${ }^{33}$ Bardi informa com exclusividade 0 jornal Secolo sobre o rompimento de uma barragem nos Alpes Bergamascos que resultou na destruição de aldeias inteiras. In: TENTORI (2000), op. cit., p. 26.

${ }^{34}$ Segundo TENTORI (2000), op. cit., p.32, no primeiro ano Belvedere sai com dez números de quatro páginas cada um, em formato de $55 \times 40,5 \mathrm{~cm}$. No segundo, com oito números, de doze ou mais páginas cada um, no formato de $40 \times$ $27,7 \mathrm{~cm}$. No terceiro ano tem o formato $21,9 \times 15,1 \mathrm{~cm}$.
} 
sobre 0 valor das obras de arte ali expostas e comercializadas. Belvedere além de divulgar os eleitos "artistas do Novecentos", uma imposição fascista que interferia também no mundo das artes, imprime em suas páginas 0 protesto contra a discriminação burguesa a alguns artistas modernos e contemporâneos não alinhados ao regime ${ }^{35}$; 0 que revela mais uma semelhança ao desafio que Bardi assumirá em relação a sociedade paulista: convencer a burguesia, através do MASP e de Habitat, do valor da cultura e da arte moderna.

Tentori chama a atenção em Belvedere para o progressivo interesse de Bardi pelo problema arquitetônico, explícito naquelas páginas e que se tornará o argumento principal, quase a razão de vida do Bardi editor moderno.

Logo no editorial do primeiro número de Belvedere, fica evidente o tom irônico e crítico que caracterizará Bardi, o mesmo que utilizará anos depois em seus ensaios nas páginas de Habitat e que farão da revista um escancarado palco de repreensão aos costumes da sociedade artística paulistana.

"Há quem diga que teremos o fuzilamento do Novecento; há quem afirme o triunfo dos professores da Academia, das taxas de importação sobre a inspiração parisiense, [que se dê] a menção onorevole nacional para os licenciados das escolas técnicas com 9 em desenho (...)." 36

Em junho de 1930, ao deixar Milão e inaugurar a primeira exposição da Galleria d'Arte di Roma, Bardi publica um texto, que marca o fim de suas atividades na primeira cidade, onde é possível identificar a semelhança com o discurso combativo que vemos na página de Habitat quase vinte anos depois; afinal, como já apontamos, a luta no Brasil permaneceria quase a mesma: a conquista de espaço e reconhecimento de uma produção moderna e a formação de uma sociedade burguesa impregnada por valores ultrapassados.

"Encerrando nossas atividades em Milão, que foi, de resto, muito modesta para com a arte moderna, não nos parece fora de propósito afirmar a nossa satisfação pela polêmica empreendida em favor da arte atual na Itália, culminada com a exposição dos "Seis artistas de Turim" (...) Essa nossa pouca atividade, que nos causou invasões na galeria, pedradas e barulho estudantil, acompanhado da "leal revolta" daqueles que cortam as telas novecentistas - fica entregue à crônica artística italiana (...) Mas a um certo momento, formou-se contra nós uma maré de gente nunca vista (...). Em resumo: nós éramos perturbadores da ordem pública artística, anti-sindicalistas, bolchevistas, porque o negociante deve ser imparcial e vender obras de todos (...) a ponto de - dos tipos mais jurados a tirar do meio o incômodo de um Bardi - partiram denúncias e inquéritos, cujo eco se ouviu na imprensa mais responsável da cidade. (resistir) era impossível. E nós perdemos a vontade de continuar a nossa batalha: cedendo as armas a amigos caros, mais frescos que nós (....." ${ }^{37}$

\footnotetext{
${ }^{35}$ Assim, no primeiro número defende da incompreensão a II Mostra do Novecentos no Palazzo de Permanente, e ao final do primeiro ano denuncia o destempero dos jovens da Accademia di Brera contra o modernismo dos "Seis pintores de Turim".

${ }^{36}$ BARDI, P. M. "Il colpo di bacchetta", Belvedere, $\mathrm{n}^{0}$ 1, p.1, 1929.

${ }^{37}$ BARDI, P. M. Belvedere, out., 1930. Apud TENTORI (2000), op. cit., p.41.
} 
Ainda durante o período em que permaneceu em Milão, Bardi dedicou-se também a outras atividades editoriais, como o livro Carrà e Soffici, sua primeira monografia que inaugura outras, como as de Burle Marx, de Portinari e de Ernesto de Fiori, realizadas nos primeiros anos de MASP e divulgadas pela revista Habitat.

0 compromisso que Bardi tem com a arquitetura é marcado pelo espaço que dedica em Belvedere ao "Novocomum" de Terragni ${ }^{38}$, no mesmo momento em que inicia contatos culturais internacionais que o levarão a ser correspondente da Itália para a L'Architecture d'Aujourd'hui, em 1931, e a viajar para a URSS em setembro de 1932. Neste período constrói laços de amizade com diversos arquitetos, favorecidos pela organização da primeira mostra do MIAR, pela troca de correspondências decorrentes das atividades jornalísticas que desenvolve no jornal L'Ambrosiano e pela direção da revista Quadrante, que o aproxima de arquitetos milaneses e romanos mais jovens. Vale destacar ainda os importantes contatos estabelecidos como correspondente do L'Ambrosiano ${ }^{39}$, entre 1930 e 1933, que torna possível a viagem realizada por Bardi em julho de 1933 de Marselha à Grécia acompanhando os congressistas do CIAM.

As relações estabelecidas por Bardi e Lina na Itália permanecem após suas vindas para o Brasil. 0 casal as mantém na medida em que isso era possível, como vemos nas correspondências trocadas e hoje arquivadas na Biblioteca do MASP e no Instituto Lina Bo e P. M. Bardi. Algumas dessas relações colaboraram para a realização, aqui, de atividades no MASP, como a destacada exposição de Le Corbusier e o curso de Nervi, os quais Habitat igualmente divulga; e também funcionam como correspondentes internacionais que os mantêm informados, estabelecendo uma verdadeira ponte entre os continentes.

Tentori chama a atenção para que todas as relações "(sem possíveis equívocos), gravitam em torno da assim chamada 'cultura racionalista', como de resto os arquitetos amigos de Bardi no campo internacional"40. 0 nível de vínculo que Bardi estabelece com os arquitetos é bastante diverso, desde breves períodos de amizade até relações intensas e longas, como a com Agnoldomenico Pica, Alberto Sartoris e Terragni que permanece até a sua morte, em 1943. Também se destaca a amizade com os engenheiros Ciocca e Pier Luigi Nervi. Com o último a proximidade o levará a participar em parceria com Lina Bo de projetos no Brasil, como a Casa de

\footnotetext{
${ }^{38}$ Artigo publicado no n.4 do segundo ano de circulação de Belvedere.

${ }^{39}$ No mesmo jornal, assinando crônicas de arquitetura, Giuseppe Pagano aparece no período em que ainda não se dedica exclusivamente à direção de Casabella. Sobre L'Ambrosiano, ver Apêndice 2 de TENTORI (2000).

${ }^{40}$ Ainda neste sentido, Tentori chama a atenção para a contradição de Bardi: de um lado sua intransigência a arquitetura que não se enquadra ao racionalismo, e de outro, nas artes plásticas, elege os artistas do Novecentos que ainda utilizam uma linguagem simbólica, como De Chirico e Sironi. Dentro dessa ambigüidade, Bardi deixa clara a esperança na aliança entre os pintores novecentistas e os arquitetos racionalistas, que, no entanto, devido a oportunidades e principalmente pela coerência de linguagem, se mantêm ligados a Piacentini, Muzio e outros.
} 
Vidro, residência do casal no Morumbi, e a Taba Guaianasis, edifício sede dos jornais Diários Associados. Nervi também terá publicado em Habitat (abril/junho de 1951) um artigo de sua autoria, "Resistência pela forma", no mesmo período em que vem para o Brasil a convite de Bardi para realizar uma palestra sobre a "profecia" do concreto no Museu de Arte.

A passagem em 1930 para a Galleria d'Arte di Roma, uma galeria pública sob a colaboração do Sindicato Nacional Fascista de Belas-Artes e da Confederação dos Profissionais e Artistas, transforma Bardi de empreendedor artístico em uma figura importante no setor das artes. Perfil amadurecido nos anos 50 quando passa a exercer em São Paulo papel fundamental no desenvolvimento e amadurecimento do campo cultural local.

"Vão emergindo claramente, dos registros as características da personalidade de Bardi: a laborosidade e a tenacidade, o empenho anticonformista pela causa da renovação arquitetônica e artística, mas também - como já revelamos - a sua não especialização." ${ }^{41}$

Na Galleria, à semelhança das instituições que atuará em São Paulo, Bardi exerceu um papel missionário, divulgando os artistas modernos italianos filiados ao sindicato, realizando exposição de artistas estrangeiros a fim de estabelecer a interlocução e o desenvolvimento das artes, realizando exposições de produtos industriais, e também mostras do racionalismo italiano, como a II Mostra Italiana de Arquitetura Racional ${ }^{42 .}$

É assumindo a dificuldade e o fracasso de sua missão que em 1933 a Galleria d'Arte di Roma interrompe suas atividades. A justificativa aponta que com aqueles métodos não conseguiria superar a defasagem existente entre o público italiano e a vanguarda Novecentos/racionalista. Com o argumento inverso, em 1954, ao deixar a revista Habitat, Bardi e Lina consideram cumprida a sua missão.

"Passados já agora quatro anos de fundação desta revista, cujo escopo foi proporcionar ao Brasil um lide onde os muitos problemas das artes pudessem ser apresentados e debatidos tendo sempre em vista a necessidade indispensável da crítica, os seus diretores e editores podem se comprazer, hoje, com o longo e profícuo caminho percorrido e com o fato de na esteira de Habitat terem aparecido tantas outras revistas de arquitetura e arte. Mas qualquer esforço ou labor verdadeiramente apaixonado não pode prosseguir até 0 infinito (...). Acreditamos que os quinze volumes de Habitat contém em si todo um panorama bem como a perspectiva de bom movimento artístico brasileiro entendido sob o ponto de vista da avaliação dos seus artífices; procuramos defender as verdadeiras personalidades que operam no supradito panorama: diferenciamos sempre a arte da mundanidade; jamais incensamos qualquer indivíduo que, sem cultura e sem idéias tenha tratado de problemas

\footnotetext{
${ }^{41}$ TENTORI (2000), p. 48.

${ }^{42}$ Foi em uma dessas mostras que se deu a polêmica em torno a Tavolo degli Orrori, colagem que reproduz de forma crítica exemplos de arquitetura acadêmica, com moda e costumes, de forma a evidenciar o seu anacronismo. Sua autoria é atribuída a Bardi, com colaboração de Pagano e Carlo Belli.
} 
da arte como assunto de botequim; nunca compartilhamos de excessivo otimismo sobre a grandeza de alguns arquitetos elevados a monumentos nacionais; jamais outorgamos diplomas a artistas após quinze lições (....."."43

Seria mais curto e leve o percurso trilhado na revista, ou o discurso publicado no décimo quinto editorial figuraria como uma conveniente forma de deixar o compromisso assumido anos antes sem comprometer suas imagens de efetivos agentes culturais.

Ainda como mais uma importante iniciativa no campo editorial, a revista Quadrante revela características que no mínimo inspiraram Habitat quase quinze anos depois, ao menos na forma de organização do grupo de colaboradores:

"O segredo financeiro de 'Quadrante' é o seguinte: os dois diretores dirigem e colaboram de graça, os colaboradores quase todos colaboram de graça, três números de "Quadrante' não custam, de colaboração, no total, mais do que cerca de 450 liras, ou talvez menos; as despesas gerais e locais são oferecidas graciosamente: em Milão, a 'Libreria del Milione’ e, em Roma, a 'Galleria d'Arte di Roma'; para as despesas de impressão e de papel se cotizaram alguns jovens arquitetos para o primeiro ano (...). 0 segredo financeiro de 'Quadrante' é, simplesmente, um segredo de paixão." ${ }^{44}$

Na direção da revista em áreas distintas Bardi aparece no setor de arquitetura e artes figurativas ao lado de Bontempelli, que permanece na área teatral e literária. É em Quadrante que Bardi passa a demonstrar simpatia aos engenheiros, logo após a realização do cruzeiro do IV CIAM, em que conhece Le Corbusier, o qual já louvara a engenharia em Vers une architecture. Na revista italiana, como também será em Habitat, a engenharia, ao lado da arquitetura, é apresentada como uma disciplina coerente com o seu tempo, onde a funcionalidade aproxima a técnica e a estética.

“(...) Mas bastará dizer que nós consideramos a arquitetura no sentido mais espacial, quando o homem modifica a natureza construindo ali a estrada, represando o rio, construindo uma torre ou quando fabrica um avião ou um navio, ou ainda quando retira de uma árvore um móvel e de um mineral uma jóia, ele determina sempre fatos arquitetônicos. (...) A arquitetura é o reflexo durável da civilização é a arte diretriz (...)." ${ }^{45}$

0 início do fim de Quadrante é marcado pelo desapontamento dos arquitetos colaboradores da revista com o resultado do concurso para o Palazzo del Littorio, em Via dell'Impero, que nega a arquitetura "racional". Também contou o desentendimento entre os diretores em relação à arquitetura de Terragni para a Casa del

\footnotetext{
${ }^{43}$ BARDI, P. M. "Editorial". Habitat, São Paulo, n0 15, p. 1, mar./abr. 1954.

${ }^{44}$ BARDI, P. M. Quadrante, n.4, ago. 1933, p. 23. Apud TENTORI (2000), op. cit., p. 75. Grifo nosso.

${ }^{45}$ BARDI, P. M. "Belvedere dell'architettura italiana d'oggi", Quadrante, nº 7, p. 23, 1933.
} 
Fascio de $\mathrm{Como}^{46}$.

Depois de quatro anos em Quadrante com um grupo formado por inovadores no campo da arquitetura, das artes figurativas, da literatura, do teatro, do cinema, e também do setor técnico e produtivo, econômico, político, agrícola e industrial, Bardi assume com Bontempelli, Italia Letteraria em janeiro de 1936, uma revista com onze anos e histórico de diversas direções ${ }^{47}$. Em dezembro de 1936, após deixar a revista Quadrante, Bontempelli deixa também a direção de Italia Letteraria, que passa a se chamar Meridiano di Roma, conservando como subtítulo Itália Letteraria, Artistica e Scientifica. Nela, entre os diversos artigos, há espaço para a arquitetura, como a discussão sobre o Plano Diretor do Vale d'Aosta, apresentado com a mesma importância das exposições racionalistas, o que inaugura no periódico a campanha em favor da boa arquitetura.

Em 1941 Bardi passa a colaborar com as revistas Tempo e Lo Stilo. A primeira, um semanário ilustrado de atualidades criado em 1937 por Alberto Mondadori, que já publicava semanalmente artigos de Bontempelli, quem provavelmente o leva para a revista. Lo Stile, criada para disputar espaço com o mercado então dominado por Domus $^{48}$ e Casabella (de Gianni Mazzocchi), era uma revista dedicada a architettura, arti, lettere, arredamento, casa e editada por Aldo Garzanti; nela Bardi colabora com artigos sobre arquitetura ${ }^{49}$ até julho de 1943.

Provavelmente, é neste momento que a vida de Lina se cruza com a de Pietro Maria Bardi. Também como colaboradora da revista Lo Stile desde seu primeiro número, graças a Ponti, antigo professor de Carlo Pagani, que 0 introduz no campo editorial e faz o mesmo com Lina, a arquiteta passa a ter textos, ilustrações e projetos publicados em revistas sob sua direção, inicialmente na Domus e Belezza e depois na revista Lo Stile.

Lina forma-se em 1939 pela Faculdade de Arquitetura de Roma, dirigida naquele momento por Gustavo Giovannoni e Marcello Piacentini50, que caracterizam uma formação pautada pela observação, preservação e restauração dos monumentos históricos. No entanto, segundo Carlo Pagani ${ }^{51}$, apesar do ambiente acadêmico, é na universidade que se consolida a formação racionalista de Lina a partir da leitura dos livros de Le Corbusier, amplamente difundidos na Itália naquele momento.

\footnotetext{
${ }^{46}$ Quadrante dedica o n ${ }^{0}$ 35-36 (outubro de 1936) a Casa del Fascio, onde Bontempelli publica um artigo negando seu valor. Bardi não admite e assim Bontempelli deixa a revista.

${ }^{47}$ Sobre o percurso de Italia Litteraria, seus diretores etc., ver TENTORI (2000), p.123.

${ }^{48}$ A revista fundada em 1941 é publicada regularmente até 0 número 31 (julho de 1943), quando é anunciado 0 bombardeamento da sede. Durante três números sai agrupada e depois retorna a publicação mensal até o final da guerra, com a direção de Ponti até novembro de 1944. Ver, TENTORI (2000), p.160.

${ }^{49}$ Para aprofundar a participação de Bardi nas duas revistas, ver TENTORI (2000), p.158 a 162.

${ }^{50} \mathrm{~A}$ arquitetura que realizam procura dar aos novos edifícios valores semelhantes à arquitetura que os circundavam, um "moderno vernacular" onde há a apropriação da forma dos edifícios do Renascimento e do Barroco.
} 
Depois de formada, Lina vai para Milão e abre escritório com Carlo Pagani. É nesta cidade, no escritório de Giò Ponti, líder do movimento pela valorização do artesanato italiano, diretor das Trienais de Milão e da revista Domus, que inicia suas atividades editoriais, ao lado de outros trabalhos que vem a desenvolver nas mais diversas áreas e escalas:

“(...) 0 trabalho: desde 0 design de xícaras e cadeiras, desde moda, isto é, roupas, até projetos urbanísticos, como o projeto de Abamo' (Estação Termal do Veneto). A atividade do escritório se estendia da construção da 'Montecatini' à organização das Trienais de Artes Decorativas e à redação da revista. (...)."

A dedicação intensa as atividades relacionadas ao universo editorial era conseqüência do início da guerra e da dificuldade de construir. A quantidade insuficiente de encomendas e a aptidão para o desenho levaram Lina a desenvolver atividade de ilustradora em revistas e jornais milaneses; atividades que também estampam as páginas de Habitat, em que assume a autoria das capas e muitas das inúmeras ilustrações que animam as "Crônicas de Alencastro"52.

"Desenvolvi, de 41 a 43, uma intensa campanha jornalística, colaborando em revistas populares semanais, como 'Tempo', 'Grazia' e 'Vetrina'. Editava também a coleção Quaderni di Domus, onde realizava atividades de pesquisa e estudo sobre Artesanato e Desenho Industrial. E comecei a trabalhar para Illustrazione Italiana.(...)."53

De acordo com o levantamento das publicações que contam com a colaboração de Lina, realizado por Campell ${ }^{54}$, verifica-se além de sua participação nas publicações antes mencionadas, a presença na revista Cordelia e Belleza, com trabalhos em sua maioria realizados entre 1940 e 1943. Chama à atenção também a parcela de trabalhos realizados em parceria com Carlo Pagani, com quem divide a autoria dos textos; e 0 trabalho de ilustração na seção dedicada a casa nas revistas Lo Stile e Grazia, revista destinada a um público amplo.

"Durante o período de janeiro de 1941 a março de 1942, o arquiteto Carlo Pagani foi redator da publicação, tornando-se redator-chefe em abril de 1942 com a edição do $n^{0} 16$, condição na qual permanece até $0 n^{0} 30$, quando se demite e deixa a revista. Lina Bo inicia sua colaboração com a revista desde seu primeiro número, em janeiro de 1941, comparecendo com artigos em números alternados até o n 31, de junho de 1943. Ela permanece na revista depois do afastamento de Pagani e, no $n^{0} 31$, assina sozinha 0 artigo sobre Luigi

\footnotetext{
${ }^{51}$ Depoimento de Carlo Pagani (1994) dado à Maria de Fátima Campello.

${ }^{52}$ Nos arquivos do Instituto Lina Bo e P. M. Bardi encontramos um "boneco" da capa da primeira publicação de Habitat que difere da impressa oficialmente. Ainda sobre a autoria das ilustrações em bico- de-pena que animam as "Crônicas de Alencastro", sabemos que há exemplares dos talentos de Pietro, também exímio caricaturista e de Flávio Motta, onde se destaca a síntese dos traços.

${ }^{53}$ BARDI, Lina Bo, apud FERRAZ (1993), op. cit., p. 10.

${ }^{54}$ Ver bibliografia em CAMPELLO (1997).
} 
Piccinato. GIENLICA, pseudônimo que aparece como autoria de várias capas, é a junção de Gi, de Giò Ponti; En, de Enrico Bo; Li, de Lina Bo; Ca, de Carlo Pagani." 55

Mas entre as experiências italianas, destaca-se pela posição e responsabilidade, a atividade que Lina exerceu na revista Domus após a ocupação do Norte da Itália pelos alemães, quando deixa o escritório de Giò Ponti e passa de colaboradora para a vice-direção ao lado de Pagani. Com a saída de Giò Ponti da Domus, em 1941, a direção da revista é alterada sucessivamente ${ }^{56}$. Em dezembro de 1943, no $n^{0} 192$, passa a ser dirigida por Melchiorre Bega, que impedido de exercer a direção por questões relacionadas à guerra, mantém 0 arquiteto Carlo Pagani a sua frente. É então no n 195 , de março de 1944, que os nomes de Pagani e Lina aparecem oficialmente como diretores ${ }^{57}$.

No período em que dirigem a revista Domus, Lina e Pagani fundam a coleção Quaderni di Domus, dedicada aos problemas da casa moderna, divulgando os melhores exemplos, italianos e estrangeiros, de mobiliário e equipamento dos últimos quinze anos, elegendo-os segundo as respostas técnicas que apresentam, como é o caso da produção em série que, naquele momento, julgam mais importantes que as questões estéticas. Segundo Lina, essa publicação impulsiona as atividades de pesquisa no campo do desenho industrial e do artesanato ${ }^{58}$; missão semelhante, como vimos anteriormente, a levaria a publicar em Habitat, sobre os mesmos argumentos, a produção de mobiliário do Studio de Arte Palma realizada em parceria com Palanti.

A experiência acumulada à frente da revista Domus durante um período de escassez como 0 da guerra, apesar de breve, provavelmente influenciou sua posição de diretora da revista Habitat, na qual a coordenação geral exigiu-lhe um domínio de todos os aspectos que envolvem a produção de um periódico, principalmente se consideramos 0 acúmulo de "papéis" que desenvolvia naquele momento. A escassez de profissionais preparados, aliada às prováveis dificuldades financeiras, fazia da Lina diretora também diagramadora, ilustradora, autora de artigos, entre outras funções. Ainda que num breve olhar sobre as páginas da revista Domus deste período é possível confundir, pela temática (principalmente nos artigos dedicados ao artesanato

${ }_{55}^{5}$ PAGANI, Carlo (1994a). Carta dirigida a Francesco Sturlini. / Letter/. Milão, arquivo pessoal de Carlo Pagani. Apud CAMPELLO (1997), op. cit..

${ }^{56}$ De 1941 a 1942 a direção é assumida por Giuseppe Pagano e Massimo Bontempelli; e de 1942 a 1943, por Guglielmo Ulrich.

${ }^{57}$ Segundo Pagani, foi sua a sugestão de oferecer a co-direção da Domus a Lina. Proposta que fez a Mazzochi justificando que por ser mulher Lina teria menos problemas em transitar nos trens entre Milão e Bérgamo, sede da revista durante o período da ocupação. No final deste mesmo ano, Pagani propõe ao editor a suspensão temporária de Domus, que se mantém "fechada" durante todo 0 ano de 1945. PAGANI, Carlo (1993). Alcune note riguardanti Carlo Pagani, 1933-1950. Milão, Arquivo pessoal de Carlo Pagani. Documento realizado por ocasião da tesi de laurea de Francesco Sturlini. Apud CAMPELLO (1997). 


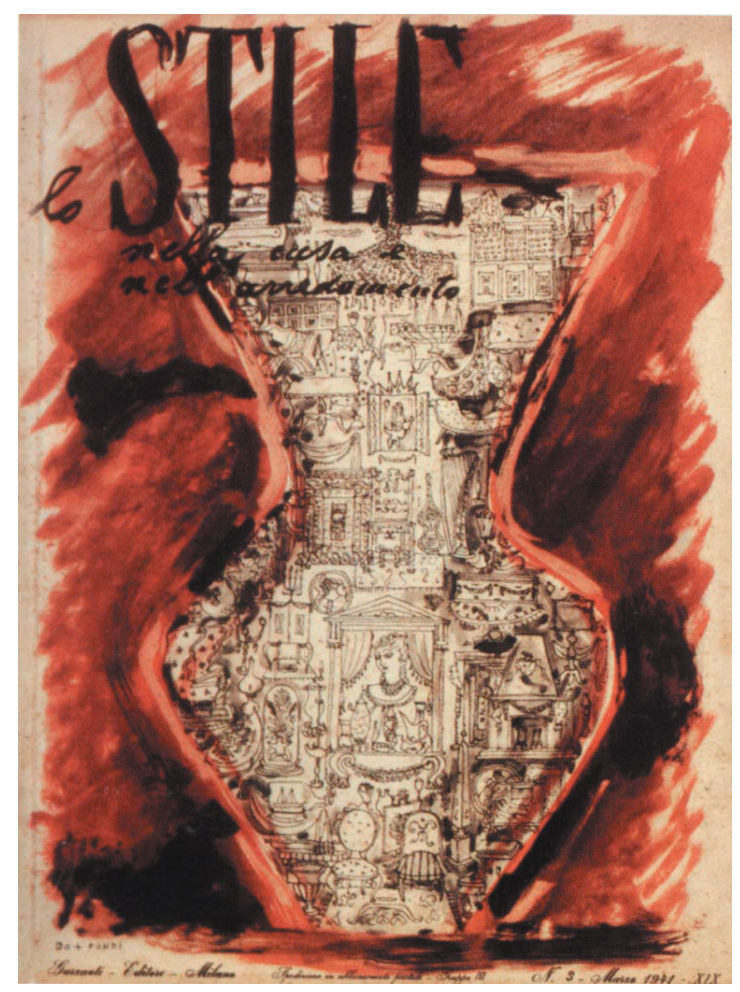

40. Revista "Lo Stilt" n 3, março, 1941. Capa de Lina e Gió Ponti.

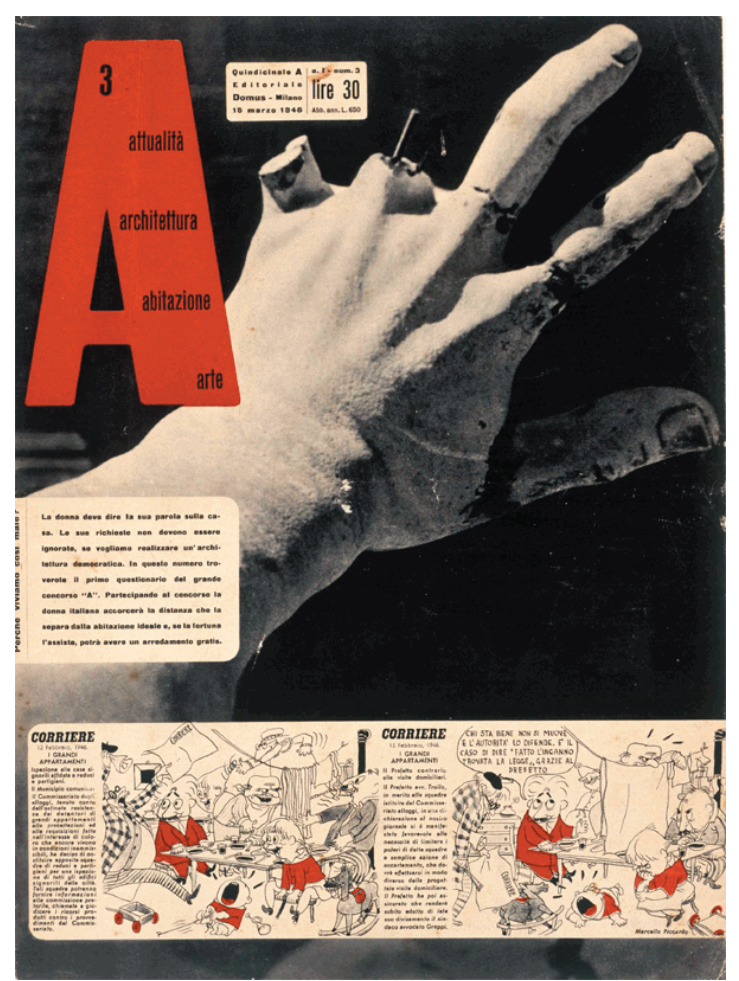

41. Revista "A" Cultura della Vita nº 3, março, 1946.

e ao desenho industrial) e pela diagramação, o periódico italiano e o brasileiro, o que confirma a influência de suas atividades anteriores.

Nos últimos anos de Itália, Lina participa da formação de uma organização sindical e profissional, o Movimento Studi Architettura, a mais importante organização de arquitetos milaneses ${ }^{59}$. A organização comandada por Ernesto Nathan Rogers, com suas origens vinculadas a arquitetura racionalista do entreguerras, propõe a retomada no pós-guerra da produção interrompida pelo conflito. Assim, mais uma vez, Lina reafirma sua postura em relação à arquitetura moderna.

Ainda antes da vinda para o Brasil, Lina trabalha no jornal Milano Sera na seção de arquitetura, desenvolvendo um trabalho de documentação da destruição das cidades italianas no pós-guerra ${ }^{60}$; e para a firma RIMA desenvolve um trabalho, a partir de viagens, de pesquisa do artesanato italiano a fim de organizar uma exposição de

\footnotetext{
${ }^{58}$ BARDI, Lina Bo. Contribuição Propedêutica ao Ensino da Tória da Arquitetura. São Paulo: Instituto Lina Bo e P. M. Bardi, 1957.

${ }^{59}$ Em Roma, outro grupo liderado por Bruno Zevi, a Associazione per l'architettura organica - APAO, realiza durante este período tentativas de aproximação com o grupo milanês. Sobre o assunto ver BRUNETTI (1986). L'architettura in Italia negli anni della ricostruzione. Florença: Alinea.

${ }^{60}$ FERRAZ (1993), op. cit., p.31.
} 
tecidos no Palazzo dell'Arte ${ }^{61}$.

Como uma das últimas experiências italianas, em 1946, Lina funda com Carlo Pagani, Raffaelo Carrieri e Bruno Zevi, uma revista semanal de arquitetura publicada pela Editoriale Domus de Milão. A revista $A$ - Cultura della Vita, que deveria ser destinada não só aos arquitetos, mas ao público em geral, foi lançada em papel jornal e sem capa dura, para ter seu custo barateado. A publicação pretendia difundir os problemas da habitação e do urbanismo no período de reconstrução que a Itália se encontrava ${ }^{62}$.

0 primeiro número da revista $A$ é publicado em fevereiro de 1946, e no $n^{0} 70$ subtítulo Attualità, architettura, abitazione e arte é trocado por Cultura della vita. Segundo Pagani, o tom polêmico assumido pela revista e sua crescente tiragem incomodam os editores da Domus, que a fecham em julho de 1946 sob a desculpa do retorno de Lina a Roma e de Zevi aos Estados Unidos. ${ }^{63}$

Anos depois, já no Brasil, Lina pensou em implantar um projeto semelhante: a revista $B$. Como a antecessora, a brasileira teria um caráter popular, com meios simples e intenções transformadoras. Essa revista voltada ao público baiano provavelmente não foi editada pelo contexto político em que foi concebida - a plena ditadura ${ }^{64}$.

Na década de 1960, depois de desenvolver atividades em parceria com Bardi vinculadas ao MASP e à revista Habitat; e com Giancarlo Palanti no Studio de Arte Palma; Lina inicia uma trajetória autônoma em que tem destaque sua atuação no Nordeste do país, uma ação cultural transformadora a partir da valorização das características da cultura local já iniciada em Habitat.

Por esse percurso fica evidente a relação entre 0 trabalho desempenhado na Itália e 0 trabalho, que anos depois, teve continuidade no Brasil. A valorização do popular iniciada na Itália do pós-guerra tem destaque nos anos 50 na revista Habitat através da publicação de diversos artigos de sua autoria e, no MASP, a partir da realização de exposições que valorizam essa causa. Neste sentido, após a experiência na Bahia, o popular ganhará proporções em seu trabalho que caracterizará fortemente sua produção de arquitetura nos anos $70 \mathrm{e}$ 80, mas isso é outra história.

${ }^{61}$ Sobre a exposição, ver 0 artigo "Al Palazzo dell'Arte - Stoffe". Domus, Milão, nº 213, set. 1946.

${ }^{62}$ Sobre a revista, ver também BRUNETTI (1986), p. 68.

${ }^{63}$ PAGANI (1993), op. cit.

${ }^{64} \mathrm{Em}$ meio ao material consultado nos arquivos do Instituto Lina Bo e P. M. Bardi encontramos um "boneco" da revista que esclarece sobre suas intenções transformadoras, que de resto fazem parte da ação cultural que Lina desenvolve em Salvador. 
Ainda durante a guerra, em Roma, Bardi abre o Studio d'Arte Palma em junho de 1944, onde além de exposição de arte, arquitetura, gráfica e livros raros, contava com um laboratório para restauro de obras de arte, gabinete de radiografia e fotografia. Foi no Studio Palma, em uma de suas conferências e debates que Pietro e Lina conheceram Pedro de Moraes Barros, embaixador do Brasil na Itália e que os revelou o Brasil como um país de inúmeras possibilidades no campo das artes e da arquitetura.

Após o intenso período vivido na Itália durante a guerra, "Pietro Maria Bardi não desejava submeter a juízo sua atuação profissional realizada no período do fascismo, como é a pratica da época, e correr o risco e ter seus direitos de exercer as atividades de jornalista e crítico cassadas” ${ }^{5}$. Por sua vez, Lina mostra desilusão pelo país.

0 casal deixa a Itália a bordo do Almirante Jaceguay levando no porão do cargueiro sua coleção de obras antigas e modernas, arte e artesanato e sua enorme biblioteca. 0 Brasil, já visitado por Bardi na década de $1930^{66}$ e por Lina conhecido através do livro de Philip Goodwin, Brazil Builds, encanta o casal, que permanece no Rio até maio de 1947.

"Chegada ao Rio de Janeiro de navio, em outubro. Deslumbre. Para quem chegava pelo mar, o Ministério da Educação e Saúde avançava como um grande navio branco e azul contra o céu. Primeira mensagem de paz após o dilúvio da Segunda Guerra Mundial. Me senti num país inimaginável, onde tudo era possível. Me senti feliz, e no Rio não tinha ruínas." ${ }^{67}$

É com o patrimônio que trazem da Europa que realizarão em novembro de 1946, no Rio de Janeiro, no saguão do Ministério de Educação e Saúde, uma "Exposição de pintura italiana antiga" (séculos XIII-XVIII). Nesta ocasião o casal é apresentado a Assis Chateaubriand, que propõe a Bardi organizar e dirigir o Museu de Arte, fator fundamental para a decisão de o casal permanecer no Brasil e estabelecer-se em São Paulo. A partir desse momento inicia-se uma relação que permite a realização para Bardi e Lina de seu projeto moderno, possível através do MASP, da revista Habitat, do IAC e de outras iniciativas que colaboraram para transformar os aspectos culturais de São Paulo.

\footnotetext{
${ }^{65}$ PAGANI (1994).

${ }^{66}$ Segundo relatos de Bardi a Tentori, em março de 1989, na ida a Buenos Aires o navio fez escalas de um dia nas cidades brasileiras de Recife, Salvador, Rio de Janeiro, Santos, Porto Alegre e também em Montevidéu. Em Santos, os viajantes aproveitaram a parada para conhecer São Paulo. A viagem compreendeu o período entre o fim de 1933 e o início de 1934. Outra fonte discordante indica que Bardi vem ao Brasil em 1936, de passagem, na volta para a Itália após uma viagem a Buenos Aires, onde promove uma exposição sobre a arquitetura racionalista italiana. In: MORAES, (1994), op. cit., p. 476.

${ }^{67}$ BARDI, Lina Bo, apud FERRAZ (1993), p. 12.
} 
A afinidade de Pietro e Lina com as idéias de vanguarda que caracterizaram seus percursos individuais na Itália iria caracterizar aqui suas atividades nas ações culturais que decorreram. Incansáveis na disseminação das sementes que romperiam com os vícios sociais e culturais, o casal convoca em Habitat intelectuais, profissionais e a população em geral para a mesma luta. 


\subsection{0 panorama cultural de São Paulo no momento da publicação da revista Habitat}

Na história política do Brasil o período de 1929 a 1954 corresponde à queda da República oligárquica (1930), pouco depois seguido de uma prolongada ditadura (1937-1945), configurando uma fase em que um profundo rearranjo político beneficiou setores ligados à economia urbana. Com o Golpe de 30 e a efetivação de um governo central autoritário viu-se a possibilidade de uma nação que culturalmente também tinha que ser caracterizada. Neste sentido um grupo de intelectuais lança um novo olhar para o Brasil na busca de pensar 0 local e 0 universal. É esta relação entre 0 que nos une e 0 que nos faz diferente que caracterizará a produção do período inicial do modernismo e assim as bases para o que veremos depois estampado nas páginas da revista Habitat na década de 1950.

0 modernismo no Brasil ao buscar exemplo nas vanguardas européias pautadas pelo modelo primitivo, pela visualidade africana e oriental, aqui se surpreende com a proximidade que o separava do nosso primitivo:

\footnotetext{
"Para os modernistas, alunos aplicados e assíduos freqüentadores dos círculos de vanguarda européia, entretanto, esse distante primitivismo, esse outro 'olhar o mundo' que se buscava fora dos limites 'civilizados' era perturbadoramente próximo e conhecido: estava sob seus próprios pés, persistia nos traços de herança cultural indígena ou africana. Nos costumes, crenças e falas ainda vivos na própria cidade, todavia indecisa entre a modernidade do tijolo e do automóvel e o passado recente da taipa e do burro de carga. Podia ser encontrado logo além das vidraças dos salões franceses das fazendas de café. Ou, mais radicalmente, no interior desse país que era preciso descobrir" ${ }^{68}$
}

Desta forma, os artistas saem na busca da nacionalidade a fim de romper com o modelo existente pautado por uma elite econômica desprovida de refinamento e cultura. Em São Paulo, na primeira metade do século XX a grande detentora do capital, a aristocracia cafeeira transferida para a capital apenas nos anos 30 e 40, caracterizava uma alta sociedade caipira que tinha como modelo o modo de vida e de consumo dos estrangeiros aqui instalados.

0 movimento nas artes plásticas e na literatura de rompimento estético e construção de uma brasilidade que marcou o início do modernismo, nos anos 30 adquiriu preocupações sociais e políticas, as quais não excluiu

${ }^{68}$ MARTINS, C. A. F. Arquitetura e Estado no Brasil. Elementos para uma investigação sobre a constituição do discurso Moderno no Brasil. A obra de Lúcio Costa. São Paulo, 1987. Dissertação (Mestrado) - Faculdade de Filosofia, Letras e Ciências Humanas. p.113. 
uma preocupação nacionalista. Segundo Arruda, neste período:

“(...) a crença nas possibilidades infinitas de desenvolvimento cultural era homóloga à convicção da modernização econômica, social e política que tinha em São Paulo sua grande promessa (...). Especificamente, produziu-se uma confluência do poder econômico e político com o 'mundo do espírito', pois todos estavam imbuídos de vontades semelhantes, ainda que elas dissessem respeito a campos diferentes. Entre 0 dinheiro e 0 intelecto ocorrem certas analogias no plano formal (...) caracterizadas pelo impulso de permanente atualização." 69

0 período entreguerras no Brasil teve um impacto bem diferente daquele ocorrido na Europa, onde o resultado foi a destruição e a retração econômica, com o fechamento das indústrias em função do deslocamento dos trabalhadores para o combate e para produção de produtos bélicos. Aqui, o fechamento do trânsito de mercadorias e pessoas entre Europa e América gerou o desenvolvimento da indústria nacional em todos os setores e um relevante impulso no setor cultural. 0 rápido crescimento das cidades marcou especialmente São Paulo que, como resultado conjunto do incremento do setor industrial, da força da economia cafeeira e da já consolidada rede introvertida de transportes, transformou-se na primeira metade do século XX em uma metrópole.

As facilidades oferecidas pelo governo à entrada de capital estrangeiro, que passam a instalar suas sedes no país, aceleram o processo de industrialização brasileiro e transforma São Paulo no centro manufatureiro do país, com quase 70\% do meio milhão de operários do Brasil em 1955.

0 processo imigratório que trouxe para São Paulo cerca de 2.230 .000 pessoas entre 1882 e 1930, nos anos 50 se impõe. A primeira geração de descendentes aqui nascidos passou a ocupar papel importante na sociedade, destacando-se em atividades do setor terciário, nos meios de comunicação, aparelhos culturais, na literatura, no cinema e no teatro. No período entre 1941 e 1949, foi a vez da migração com 431.153 brasileiros vindos de outros estados ${ }^{70}$.

A aproximação entre imigrantes ascendidos e a burguesia agrária caracterizam uma grande mobilidade social nos anos 50 em São Paulo, realizada pela união matrimonial - como é o caso de Lasar Segall e Gregório Warchavchik, que ao ligam-se aos Klabin - ou pelo convívio estreitado nos redutos de cultura onde a burguesia encontrava-se com os imigrantes muitas vezes no papel de mecenas.

${ }^{69}$ ARRUDA, Maria Arminda do Nascimento. Metrópole e cultura: São Paulo no meio do século XX. Bauru, SP: Edusc, 2001, p. 107.

${ }^{70}$ Ibidem. 
As alterações econômicas e culturais resultam em novas formas de organização social, reflexo da alteração das instituições existentes e da criação de novas, fazendo São Paulo sair do papel de colônia cultural que antes ocupava.

A crise de 1929 e a Segunda Guerra Mundial repercutiram nos vínculos de dependência entre os centros culturais na Europa e os países que em torno deles gravitavam, como o Brasil. Com o fechamento dos portos dificultavam-se as freqüentes viagens de longa estadia para a Europa, comuns aos filhos da aristocracia paulistana e cobiçada pelos estudantes da Escola Nacional de Belas Artes ${ }^{71}$. Cruzar o oceano demandava esforços que faziam das exposições itinerantes algo nada freqüente; o que com a guerra prejudicou ainda mais o intercâmbio artístico-cultural e impulsionou 0 aquecimento do setor cultural local.

Inicialmente coube a intelectualidade paulistana iniciar o processo de modernização cultural, que na década de 1940 seria incrementado pela instalação de importantes instituições, como a Universidade de São Paulo e os museus. Neste momento cabia ao próprio meio artístico promover o intercâmbio local e internacional, como os Salões de Maio ${ }^{72}$ e as exposições da Família Artística Paulista ${ }^{73}$. Também um grupo da Faculdade de Filosofia, Ciências e Letras da Universidade de São Paulo, organizado em torno da revista Clima, colaborou para 0 amadurecimento do campo intelectual, alterando positivamente o campo da crítica artística que até este momento era realizado por jornalistas sem formação específica.

\footnotetext{
${ }^{71}$ A ENBA, como prêmio, enviava alunos que se destacavam para complementação da formação. Neste período, as viagens de estudo eram um projeto familiar da alta sociedade ao qual os jovens eram submetidos.

${ }^{72} 0$ Salão de Maio buscou a consolidação das pesquisas artísticas modernas no país, após as experimentações estéticas da década anterior. Contou com três exposições e uma publicação, a revista RASM. № $1^{0}$ Salão, a partir de 25 de maio de 1937, só participam artistas nacionais como Tarsila do Amaral, Victor Brecheret, Lívio Abramo, Alberto Guignard, Cícero Dias, Lasar Segall e Ernesto de Fiori. Sem júri nem premiação, a mostra concentrou-se na venda e divulgação dos trabalhos. No $2^{\circ}$ Salão, inaugurado em 27 de junho de 1938, por intermédio de Flávio de Carvalho, contou com participação estrangeira: os abstracionistas Erik Smith, Roland Penrose, John Banting e Ben Nicholson e Leopoldo Méndez e Dias de Léon. Entre os artistas nacionais, os presentes no anterior, entre outros. $03^{\circ}$ Salão, inaugurado 1939, de exclusiva responsabilidade de Flávio de Carvalho, contou com 39 artistas: Clóvis Graciano e Fulvio Pennacchios, além dos nacionais presentes nas edições anteriores, e destaque para a participação de Alexandre Calder, Josef Albers e Alberto Magnelli.

${ }^{73}$ Grupo de artistas organizados por Rossi Osir e Waldemar da Costa, em reação ao grupo do Salão de Maio. Contou com 0 Grupo Santa Helena nas três grandes exposições por ele realizadas, e ainda com a participação no $1^{\circ}$ (novembro de 1937) de Aldo Bonadei, Alfredo Volpi, Anita Malfatti, Clóvis Graciano, Fulvio Pennacchi, Humberto Rosa, Mario Zanini, Rossi Osir e Manuel Martins, entre outros. No $2^{\circ}$ salão, em 1939, além dos antigos participantes, esteve Candido Portinari, Nelson Nóbrega, Alfredo Rizzotti e Ernesto de Fiori. 0 último salão, em 1940, no Rio de Janeiro, contou com as participações inéditas de Carlos Scliar, Paulo Sangiuliano e Bruno Giorgi.

${ }^{74}$ Dados do Anuário Estatísticos do Estado de São Paulo, de 1941, relativos ao número e época dos periódicos do Estado, localizam bem os anos do surto: 72 dos 116 periódicos existentes em 1940, ou seja, dois terços, haviam sido fundados
} 
0 clima de curiosidade e a sede de conhecimento movimentavam o meio editoria $7^{74}$ e, segundo Durand (1989), transformavam os assuntos culturais em fonte de grande interesse para os jornalistas. Os periódicos tinham importante papel na estruturação do campo intelectual durante os anos 30 e 40 que, no entanto, pela falta de um quadro profissional especializado eram carentes de uma crítica séria. A inexistência de críticos de arte em São Paulo favoreceu a colocação e rápida emergência dos "entendidos em arte" e a imigração de marchands. A lacuna era preenchida, mal eram notados 0 interesse e alguma intimidade com 0 assunto; neste sentido vale lembrar a já conhecida passagem do encontro de Geraldo Ferraz com Oswald de Andrade e Tarsila do Amaral, que o transformou em crítico do grupo modernista ${ }^{75}$.

A escassez de uma crítica séria de arte e arquitetura permanece até os anos 50 , como vemos manifestar inúmeras vezes a revista Habitat em suas páginas na crítica a crítica, por meio de artigos assinados principalmente por

entre 1930 e 1939 e quatro quintos deles o foram de 1920 em diante. Computados por tipo e periodicidade, 24 eram jornais, a metade dos quais diários, e nada menos de 80 revistas. Apud DURAND (1989), op. cit ., nota p. 104.

${ }^{75}$ Ferraz descreve que a partir do momento que Oswald notou a intimidade que tinha com os artistas modernos, Delaunay, De Chirico, Brancusi etc.; conhecidos seus dos livros, o considerou demais evoluído para um jornalista de província e 0 valorizou, passando a apresentá-lo como a mais recente conquista do modernismo; assim iniciou-se nas redações dos jornais e no salão de Tarsila. Sobre esse encontro ver FERRAZ, Geraldo. Depois de Tudo: Memórias, Rio de janeiro: Paz e Terra/Sec. Municipal de Cultura de S. Paulo, p.21 e 24.
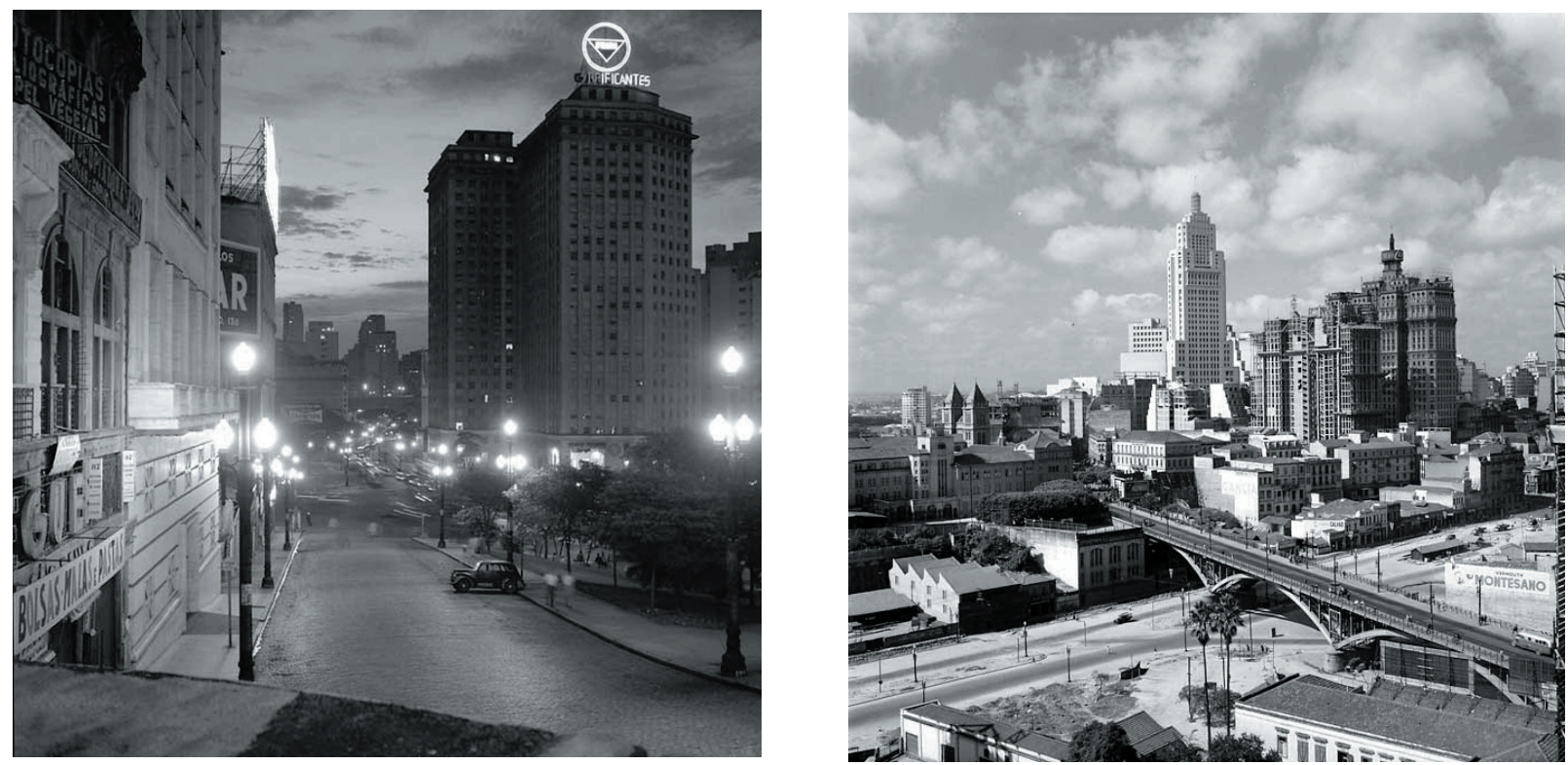

Fotos realizadas em 1954 por German Lorca, fotógrafo oficial do IV Centenário.

42. Rua Doutor Falcão: "Aqui do lado é agora o prédio da prefeitura. Aqui é a Praça da Bandeira - hoje tá tudo mudado - e essa pontinha é o prédio Mattarazo.

43. "Vista de São Paulo pela avenida Prestes Maia, e o viaduto Santa Ifigênia." 
Pietro Maria Bardi.

Colabora para o fortalecimento do campo cultural em São Paulo a formação de uma "elite esclarecida" nos anos 50, saída dos bancos das instituições de ensino superior, como da Escola de Sociologia Política, fundada em 1933, e Universidade de São Paulo, em 1934, responsável por uma nova sociabilidade que gera novas formas de produção cultural e expressão intelectual. Também foi fundamental para o impulso do debate no campo da arte e da arquitetura o aumento do número de profissionais oriundos das faculdades de arquitetura e urbanismo, criada em 1947 com o Instituto Mackenzie e, em 1948, com a FAU-USP; a já mencionada fundação do Museu de Arte de São Paulo em 1947 e do Museu de Arte Moderna6, em 1948, que a partir de 1950 organiza a primeira Bienal de $\mathrm{Arte}^{77}$ que intensifica o trânsito entre a produção artística local e a internacional.

\begin{tabular}{|c|c|c|}
\hline 1941 & Revista Clima & $\begin{array}{l}\text { Antonio Candido, Gilda de Mello e Souza, Décio de } \\
\text { Almeida Prado, Lourival Gomes Machado, Paulo } \\
\text { Emílio Salles Gomes, Ruy Galvão de Andrade } \\
\text { Coelho }\end{array}$ \\
\hline 1947 & MASP - Museu de Arte de São Paulo & Assis Chateaubriand \\
\hline \multirow[t]{3}{*}{1948} & $\begin{array}{l}\text { MAM } \\
\text { Studio de Arte Palma } \\
\text { Móveis Z }\end{array}$ & $\begin{array}{l}\text { Francisco Matarazzo Sobrinho } \\
\text { P. M. Bardi, Lina Bo e Giancarlo Palanti } \\
\text { Zanine Caldas }\end{array}$ \\
\hline & EAD - Escola de Arte Dramática & Alfredo Mesquita \\
\hline & TBC - Teatro Brasileiro de Comédia & Francisco Matarazzo Sobrinho e Franco Zampari \\
\hline 1949 & Cia. Cinematográfica Vera Cruz & $\begin{array}{l}\text { Francisco Matarazzo Sobrinho e } \\
\text { Alberto Cavalcanti (diretor) }\end{array}$ \\
\hline 1950 & $\begin{array}{l}\text { TV Tupi } \\
\text { Revista Habitat }\end{array}$ & $\begin{array}{l}\text { Assis Chateaubriand-Diários Associados } \\
\text { Lina Bo Bardi e Pietro Maria Bardi }\end{array}$ \\
\hline 1951 & $\begin{array}{l}\text { Instituto de Arte Contemporânea } \\
\text { I Bienal Internacional de Artes de São Paulo }\end{array}$ & $\begin{array}{l}\text { MASP } \\
\text { Salão de Baile - Trianon (MAM) }\end{array}$ \\
\hline 1952 & Exposição do Grupo Ruptura & MAM \\
\hline 1953 & II Bienal Internacional de Artes de São Paulo & Ibirapuera \\
\hline 1954 & $\begin{array}{l}\text { Inauguração do Parque do lbirapuera } \\
\text { Comemorações do IV Centenário de São } \\
\text { Paulo }\end{array}$ & Oscar Niemayer \\
\hline
\end{tabular}

Alteração do cenário cultural em São Paulo na década de 1950.

Dá-se nesse momento, segundo Durand, a constituição das artes plásticas no Brasil:

\footnotetext{
${ }^{76}$ Instituição formada pelo industrial Francisco Matarazzo Sobrinho, que anteriormente já havia empreendido outras importantes iniciativas no campo da cultura, como a Companhia Cinematográfica Vera Cruz e o Teatro Brasileiro de Comédia, um grupo teatral profissionalizante.

${ }^{77}$ A primeira Bienal, em 1951, teve como sede um pavilhão construído no Belvedere do MASP especialmente para abrigar
} 
"a-) (...) o começo do comércio de antigüidades, a presença de marchand estrangeiro, a expansão dos jornais e o surgimento do noticiarista e crítico de arte, o trabalho de animação artística preenchido por gente "de sociedade" impossibilitada de fazer vilegiatura em Paris. b-) 0 da alteração nos esquemas de percepção que estruturam o gosto em matéria de artes plásticas, arquitetura e decoração (...) Nesta segunda ordem de fatores é possível enquadrar as campanhas de defesa do patrimônio histórico e artístico, as iniciativas de catalogação, difusão e promoção do "folclore" brasileiro, o despontar de um ensino artístico infantil (...)"78

A "redescoberta do Brasil" é marcada no início dos anos 20 com as incursões aos sítios históricos do Brasil Colônia dos modernistas abastados de São Paulo. Que através da valorização do patrimônio histórico e artístico nacional procuram construir uma "trama histórica"79, na qual arte moderna busca romper com as características do passado e incorporar um pretenso internacionalismo. Este é o quadro em que o modernismo brasileiro move-se a partir do Estado-Novo: à busca de definir um sentido nacionalista, tendo como projeto a "construção de uma identidade", perante o passado "opaco colonial"80.

Na constituição de uma história oficial vale aqui destacar a "contribuição"81 norte- americana na realização de esforços para a aproximação econômica, política e ideológica com os países latino-americanos, ocupando 0 posto deixado vago pela Europa. No campo ideológico, a realização de publicações acerca da produção artística brasileira colaborou para regenerar a confiança em nós, e diminuir o desastroso complexo de inferioridade de mestiços que a nação vinha cultivando ${ }^{82}$. Entre as publicações tem destaque o conhecido Brazil Builds. Architecture New and Old. 1532-1942, editado em 1943, resultado da exposição sobre a arquitetura moderna brasileira organizada pelo arquiteto Philip L. Goodwin e fruto da iniciativa do Museu de Arte Moderna de Nova York.

É a imagem projetada por essas publicações e os demais periódicos internacionais que fazem a produção brasileira ser conhecida fora e dentro de seus limites territoriais e que apontam a perspectiva de um país

o evento. 0 apogeu ocorreu no ano de comemoração do IV Centenário de São Paulo, em 1954, quando a Bienal foi sediada nos edifícios do recém-inaugurado Parque do Ibirapuera, que passou a ser sua sede definitiva.

${ }^{78}$ DURAND(1989), op. cit., p.89.

${ }^{79}$ MARTINS, 1987, op.cit., cap.2.

80 Ibidem.

${ }^{81}$ Neste momento os EUA passam a ocupar o novo centro cultural na América, "(...) desde de 1940 o governo norteamericano, temeroso da influencia nazista na América Latina, orquestra através do Departamento de Estado amplo programa ideológico de reforço do valor da nação americana perante os povos da América do Sul. Esse serviço foi confiado por Roosevelt ao jovem banqueiro Nelson Rockefeller. Cabia a tal serviço, conhecido por Birô Interamericano, além do apoio econômico, estabelecer um vigoroso programa educacional, de relações culturais, de informações e de propaganda." In: MOURA, Gerson. Tio Sam Chega ao Brasil. A Penetração Cultural Americana, São Paulo: Brasiliense, Col. Tudo é História, nº 19, 1984, p.21, apud DURAND (1989), op. cit., p. 109.

${ }^{82}$ Comentários de M. ANDRADE no artigo "Brazil Builds" para Arte em Revista, 4 de agosto de 1980, p. 25, apud DURAND, op. cit., p. 110. Referências acerca das produções que incluem pesquisa sobre arte brasileira, ver MARTINS, W. História da Inteligência Brasileira, São Paulo: Cultrix, v. VII, (1933-1960). 
onde as promessas de desenvolvimento econômico e cultural possibilitam a concretização de projetos que na Europa, com seus vícios e poderes, não encontra lugar.

0 aumento dos empreendimentos culturais transformou qualitativamente as experiências em todos os campos de expressão. A diferença entre a geração de modernistas das décadas de 1920 e 1930 e as seguintes foi a transferência (e a mudança de caráter) do mecenato das mãos da aristocracia paulista para as mãos de instituições criadas por personalidades do meio empresarial, que passam a investir fortemente no campo das artes eruditas a exemplo de Nelson Rockefeller. 0 empresário norte-americano, à frente da administração do Museu de Arte Moderna de Nova York, entre 1946 e 1951, inspirou os empresários brasileiros demonstrando haver "compatibilidade entre arte e negócio".

Assim, na década de 1950 há a valorização da cultura não mais com função aristocratizante, mas dentro de um projeto maior de desenvolvimento do país no qual Habitat irá colaborar.

No momento que antecede o lançamento de Habitat havia no mercado editorial uma demanda por veículos dedicados exclusivamente ao campo das artes. As palavras de Geraldo Ferraz publicadas no "Suplemento Literário" do Diário de São Paulo ao longo de 1948 alertam para esta questão e comemoram a chegada de um jornal de artes que pretendia cumprir este papel:

“Já vem tarde a idéia de um jornal de artes que nem dizem será o 'Artes Plásticas' (...). Porque efetivamente não estão dando para tanto movimento em artes as mirradas crônicas nos jornais diários. É preciso 'algo mais', assim como publicações especializadas. Não sei o jeito de 'Artes Plásticas', mas penso que é chegada a hora de jornais e de publicações mais de arte, revistas mesmo com pequena tiragem que é para começar a haver 0 intercambio, notícias ao Brasil e ao mundo. Vejamos qual dos museu lançará a revista. (...)"83

E após a publicação do jornal, o descontentamento permanece:

"Ainda não surgiu a publicação correspondente a um movimento como o que marcou a segunda parte do ano de 1948, e que, parece-nos, irá se desdobrar por 1949 afora. Pelo menos a programação do Museu de Arte não conhece limitações nem interrupções. Ao contrário. E é lamentável não ter uma publicação que acompanhe tudo isso, que registre estes acontecimentos, que possa servir de repositório de tanta vitalidade. Alguém está na obrigação de criar, com vontade, com coragem, a revista de arte que São Paulo precisa, com seus dois museus e suas exposições, e até mesas redondas, quando não com a vinda de elementos de fora, um Leon Degand, um Calder, para contribuírem com os reflexos mais atuais da criação, do debate, da pesquisa, sobre os meios e os artistas." 84

${ }^{83}$ FERRAZ, Geraldo. "Suplemento Literário". Diário de S. Paulo, 25 de julho de 1948. apud NEVES, Juliana. Geraldo Ferraz e Patrícia Galvão: a experiência do Suplemento Literário do Diário de S. Paulo, nos anos 40. São Paulo: Annablume; Fapesp, 2005. p. 184.

${ }^{84} \mathrm{Ibidem}$. 
No mesmo "Suplemento Literário" em que Ferraz registrava essas palavras, Pietro Maria Bardi colabora no período que antecede a fundação do MASP, momento em que apresenta as aquisições e a formação do acervo do Museu e discorre sobre questões relativas às discussões em torno de museus, levantadas no continente europeu e nos Estados Unidos ${ }^{85}$, indicando assim a direção que daria ao "seu" e tentando aproximar os paulistas da iniciativa de Chateaubriand.

Não foi em 1949, mas em fins de 1950 que Habitat, "atendendo a pedidos", é lançada. A revista não apenas cumpre mais que o papel de repositório dos acontecimentos culturais e artísticos da cidade, como aparece para difundir uma nova postura do público diante da produção artística. Uma postura comprometida com os princípios de uma sociedade moderna possível através das artes. As palavras de Geraldo Ferraz no "Suplemento Literário" 86 dos Diários Associados, de propriedade de Assis Chateaubriand, levanta a hipótese de um "aquecimento dos motores" na dedicação à cultura e à arte que seus veículos de comunicação passam a ter e a "preparação do terreno" para o futuro público leitor de Habitat.

\footnotetext{
850 mesmo texto "Para uma nova cultura do homem" publicado como editorial da revista Habitat, São Paulo, ñ 2, que discorre sobre o papel educativo dos museus e as recomendações que a Unesco faz em relatório, já havia sido publicado no "Suplemento Literário", em 27 de julho de 1947.

${ }^{86} 0$ "Suplemento Literário" do Diário de S.Paulo (1946) criado por Geraldo Ferraz e Patrícia Galvão é a primeira experiência desse tipo de empreendimento no âmbito do jornalismo paulista, tendo precedido o "Suplemento Literário" de 0 Estado de S.Paulo - que reuniu em novas bases os integrantes do Grupo Clima, responsáveis pela edição da revista Clima, entre 1941 e 1944. 0 empreendimento jornalístico que durou apenas dois anos divulgou 0 que de mais importante estava acontecendo na cena cultural, literária e artística da época. Para obter mais informações ver NEVES, (2005). op. cit.
} 


\subsection{Lina, Bardi e colaboradores}

Pouco se sabe oficialmente sobre a forma como foi organizada a revista Habitat. Os arquivos pesquisados e os documentos encontrados quase nada revelam sobre seus bastidores, mas como todo bom projeto, Habitat teria sido movida por intenções que, antes mesmo de dar início a sua concretização, reuniu esforços pessoais e financeiros.

Partindo o pressuposto de que Habitat seria uma importante peça da implantação de um projeto maior de Bardi e Lina; somado aos depoimentos de Flávio Motta e Luis Hossaka em torno da revista, e do próprio Bardi ao explicitar a organização de Quadrante (periódico que organizou e dirigiu na Itália), faz-se supor que seu grupo de colaboradores tinha além de afinidades pessoais com o casal, afinidades de discurso e de ação profissional com o projeto moderno que aqui implantavam.

Colaboram para este entendimento documentos encontrados nos arquivos históricos da Biblioteca do MASP e do Instituto Lina Bo e P. M. Bardi, com destaque para as correspondências trocadas entre Bardi e Giedion entre junho e dezembro de 1948, uma correspondência com data de 28 de setembro de 1948 entre Lina e Portinari e a monografia de Lina com data de setembro de 1978 que discorre sobre fatos em torno da criação de uma revista de arquitetura ainda em 1946. Esses documentos “lidos" conjuntamente indicam possíveis alterações nas intenções do projeto inicial de uma revista de arte e arquitetura e sua realização, com o primeiro exemplar de Habitat em novembro/dezembro de 1950.

A partir também desses documentos verifica-se a reaproximação entre Bardi e Giedion, que como presidente do CIAM é convidado por Bardi a ministrar no MASP uma conferência sobre a importância da arquitetura moderna. 0 Museu sob sua direção é apresentado na correspondência como 0 fator responsável por fixar sua residência em São Paulo. Na carta-resposta Giedion mostra-se grato e disposto em aceitar o convite para a visita ao Brasil, convite também realizado por Niemeyer e que coincidia com seus planos de viagem à Argentina, onde preparava a publicação de seu livro Space, Time and Architecture. Mas é na carta enviada em dezembro do mesmo ano que nos interessa. Nela Bardi confirma a viagem e faz referência ao projeto de uma importante revista de arquitetura que estaria organizando: 
"I was able only today to talk with Niemeyer about our idea of inviting you to Brazil. (...)

We have decided two things: first os all to ask and to make the possible for you to be invited officially by the brazilian government to come to this country and give two series of lectures, one at Rio de Janeiro and other at the "Museu de Arte de São Paulo". We have alredy given the first steps.

Secondly: we shall publish an important architecture magazine that shall be organized and oriented by Niemeyer, Eduardo Kneese de Mello, Lina Bo (my wife, that has been director of "Domus" before Rogers, and of "A"), Gian Carlo Palanti (that was a writer and organizer of "Construzioni"), Candido Portinari and by me.

For both things I shall write you soon again a more complete letter. In the meantime, I remain with best wishes. "187

Confirmando as intenções de Bardi, uma correspondência de Lina endereçada a Portinari com data anterior, setembro de 1948, confirma os nomes que figurariam no comitê diretivo da revista e demonstra que o projeto naquele momento, quase um ano antes da publicação do primeiro número de Habitat, apresentava-se em vias de concretizar-se:

"(...) Riguardo allá rivista le comunico lê seguinti cosi che lei per favore dirá ache a Oscar Niemajier:

Abbiamo parlato com Kneese de Mello; che há accettato do far parte del Comitato Direttivo per l'architettura (come d'acoordo).

La carta da lettere della revista è già in tipografia com i due indirizzi di Rio e San Paolo; è molto semplíce; appena pronta la manderò.

Ho telegrafo a Marcos perchè occo prono di urgenza lê piante e qualche fotografia in nero del Banco Boa Vista; occorrono per lê quattro pagine pubblicitarie che bisogna preparare súbito. Veda per favore di sollecitare lei, Niemajer.

La rivista resta costituita cosi

Comitato direttivo: Architetti, Oscar Niemajier, Eduardo Kneese de Mello, Giancarlo Palanti, Candido Portinari e Pietro Maria Bardi. Poici sarà Marcos che curerà la redazione e il materiale a Rio e io organizzerò la rivista.

Appena pronti i flogi di impaginazione e la carta da lettere li manderemo. Domani mandaremo le lettere di recíproco amichevole impegno.

Sto multo lavorando per sormontare lê difficotà.

Il catalogo della sua espasizione viene bene; mio marito lê dirà poi quando mandare i quadro; in ogni modo la sua venuta resta fissata per il 28 ottobre assieme a Niemajer, questo è importante anche acli effetti della pivista. ( . . . ) $)^{\prime 88}$

${ }^{87}$ Correspondência de Pietro Maria Bardi a Siegfried Giedion, com data de 7 de dezembro de 1948; encontrada no acervo histórico do MASP. Documento transcrito na integra ver ANEXO 05 (grifo nosso).

${ }^{88}$ Trecho de correspondência de Lina Bo para Portinari, datada de 28 de setembro de 1948. Encontrado no acervo histórico do Instituto Lina Bo e Pietro Maria Bardi. (Envelope 11.P.1). ver ANEXO 06 
Outra importante fonte de informação é o texto "Sobre a 'Forma na Arquitetura' de Oscar Niemeyer”. Escrito quase vinte anos após as correspondências anteriores, neste Lina discorre sobre a obra do arquiteto, relata 0 início sua relação com Niemeyer e neste contexto localiza a revista Habitat:

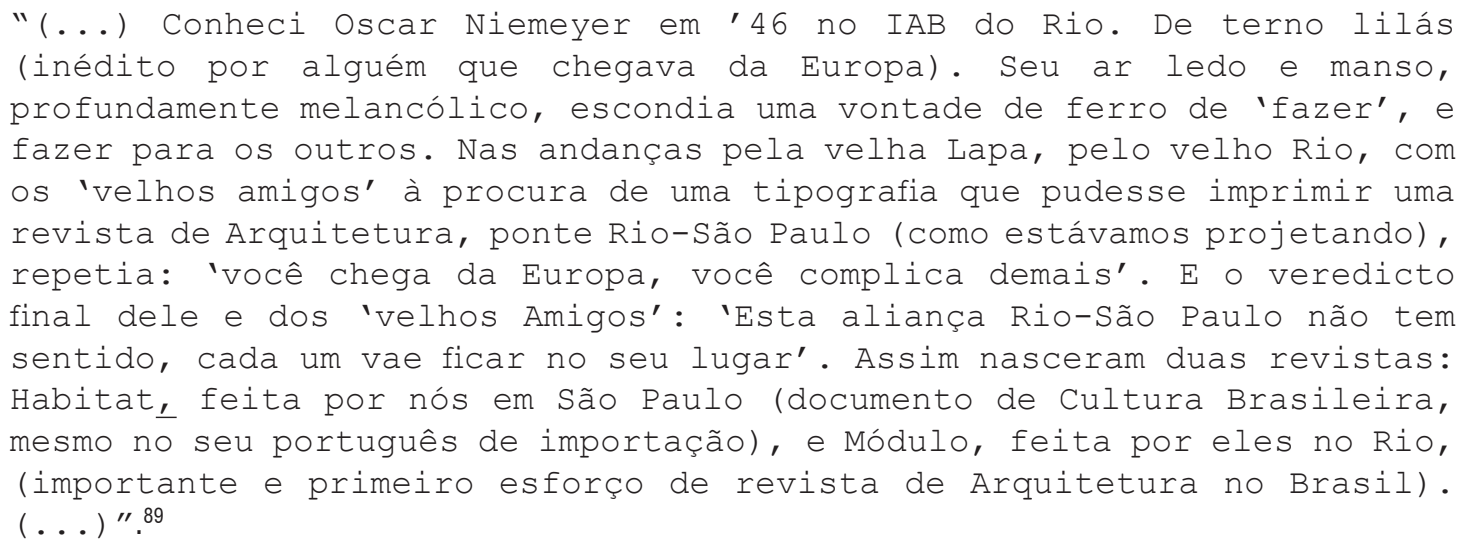

Os anos que separam o relato de Lina e os fatos ocorridos podem ser responsáveis por incorreções de dados e levam-nos a duvidar principalmente das datas citadas. Se o encontro na Lapa foi ainda em 1946, não teria sido aí estabelecido o fim do projeto de uma revista de arquitetura que faria a ponte Rio - São Paulo, sugerido nessa ocasião por Niemeyer e seus "velhos amigos"? No entanto, as correspondências da época de Lina e Pietro revelam que em fins de 1948 há ainda a permanência desse projeto "ponte Rio-São Paulo", principalmente quando verificamos os nomes propostos para figurar em sua direção.

Esses registros revelam um "projeto" ainda fresco, no momento em que Bardi e Lina veiculavam as primeiras idéias de organizar uma revista de arquitetura no Brasil. É possível "ler" no relato de Lina que, apesar da experiência acumulada na Itália, o casal recém-chegado aqui, procura se cercar da credibilidade de um Oscar Niemeyer, de um Candido Portinari e da arquitetura carioca, a genuína arquitetura moderna brasileira que a Europa conhecia através do Pavilhão Brasileiro na Feira Internacional de Nova York de 1939, do catálogo da exposição do MoMA e pela qual Lina se encantou ao chegar à baía de Guanabara. Também a participação de Eduardo Knesse de Mello entre os organizadores da revista, que neste momento encontra-se na direção do Instituto dos Arquitetos do Brasil ${ }^{90}$ e representa importante papel na organização da classe profissional ainda em formação no Brasil, confirma as intenções de cercar-se de figuras consagradas internacional e nacionalmente

${ }^{89}$ Texto de Lina Bo datado de 9 de julho de 1978, encontrada no acervo histórico do Instituto Lina Bo e Pietro Maria Bardi. Documento transcrito na integra, ver ANEXO 02.

${ }^{90}$ Instituição inaugurada em 1943 e que representara naquele momento a organização da classe que ainda engatinhava sua autonomia no país. 


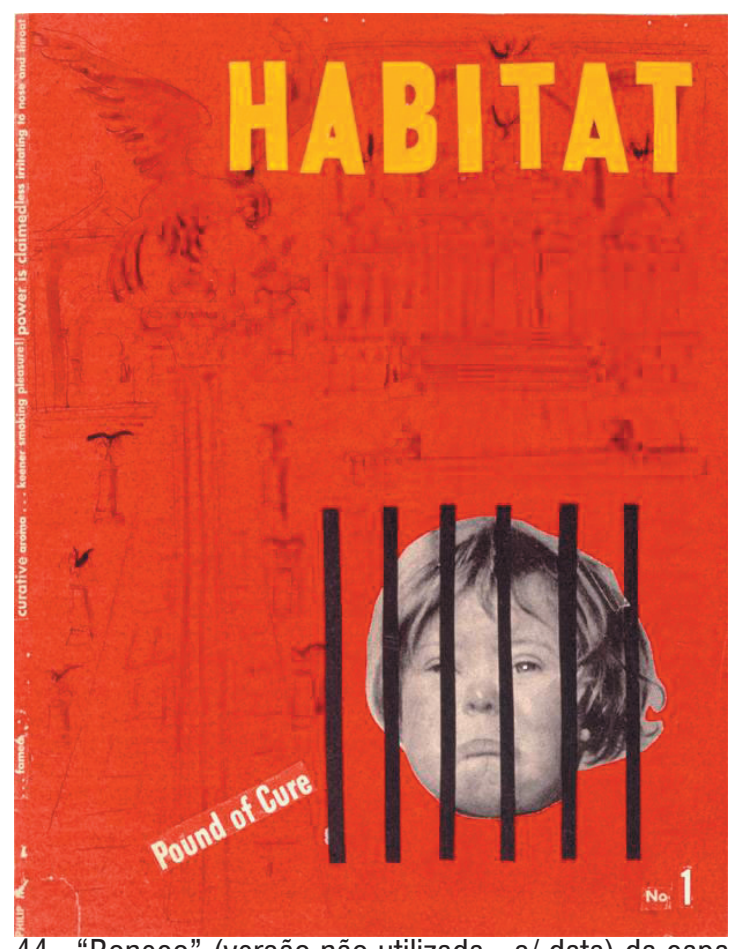

44. "Boneco" (versão não utilizada - $\mathrm{s} /$ data) da capa para o primeiro número da revista Habitat. 0 projeto gráfico é bastante distinto do da versão final, o que nos leva a supor que tenha sido realizado anos antes. assegurando assim 0 sucesso da publicação.

A idéia de uma revista que estabeleceria a ponte RioSão Paulo, cobrindo o universo de arquitetura do Rio de Janeiro como a capital do país e o centro gerador da arquitetura moderna brasileira; e de São Paulo como centro econômico e também produtor de reconhecida arquitetura moderna, foi substituída em Habitat pelo recorte na arquitetura moderna produzida em São Paulo. Do comitê diretivo inicialmente proposto não consta em Habitat nenhum dos nomes anunciados a Giedion em 1948. Oscar Niemeyer em nenhum momento aparece como colaborador direto, assinando artigos como irá fazer na revista Módulo91 projetos ${ }^{92}$ publicados entre a primeira e a décima quinta edição. Portinari aparece uma única vez, na revista Habitat $\mathrm{n}^{0} 11$, em "Os afrescos da Igreja de Batatais", um artigo sem autoria que apresenta ilustrações e detalhes de sua obra. A ausência de Eduardo Knesse de Mello como colaborador direto e de sua produção de arquitetura ${ }^{93}$, pode ser explicada tendo em vista seu envolvimento direto com o Museu de Arte Moderna de Ciccilo Matarazzo, a instituição que irá "disputar espaço" com o MASP, e a qual a revista se mostrará bastante crítica em seus primeiros anos.

0 arquiteto Giancarlo Palanti94 é o único dos nomes presentes no primeiro "projeto", além de, é claro Bardi e Lina, que permanece entre os colaboradores da revista Habitat. Palanti emigra para o Brasil em 1946, provavelmente movido pelos mesmos motivos que levaram o casal Bardi a desembarcar no Rio de Janeiro no mesmo ano. Formado na Escola Politécnica de Milão em 1929, pertenceu à segunda geração de arquitetos racionalistas do país e deixou a Itália com uma reconhecida produção profissional abrangendo desde o desenho industrial até

\footnotetext{
${ }^{91}$ Fundada e dirigida por Oscar Niemeyer, a revista Módulo começou a ser publicada a partir de março de 1955. Foi interrompida em 1965 com a instalação do regime militar após o golpe de 1964, tendo sua redação invadida e seus números apreendidos. Permanece suspensa até 1975, quando volta a ser editada até 1989.

92 Ver Anexo 2 - Índice Classificado e Comentado.

${ }^{93}$ Neste momento Kneese de Mello já realizara importantes projetos de arquitetura com caráter marcadamente moderno, como o Edifício Japurá em São Paulo projetado na década de 1940.

${ }_{94}$ Para maiores informações sobre a atuação profissional de Giancarlo Palanti, ver SANCHES, Aline Coelho. "A obra de Giancarlo Palanti em São Paulo". www.vitruvius.com.br/arquitextos/arq031/arq031_01.asp - 51k, acesso dez. 2006.
} 
projetos urbanísticos. Palanti teve também importante atuação como redator das revistas Domus (1932-1933) e Casabella (1933) e como diretor, com Franco Albini, da revista Casabella Costruzioni (1946), e foi ainda professor do Politécnico de Milão entre 1935 e 1946.

Sua trajetória profissional e pessoal 0 une ao casal Bardi marcando uma importante parceria nos primeiros projetos a serem implantados no Brasil. Na sociedade no Studio de Arte Palma - cujo objetivo era desenvolver um mobiliário moderno, adaptado ao clima e aos materiais locais cujo fim seria a produção industrial em larga escala - Palanti e Lina realizam uma série de móveis e vários projetos de interiores entre 1947 e 1950, os quais Habitat irá divulgar ao longo das primeiras edições. Em dois momentos Palanti aparece na revista assinando a autoria de artigos relacionados a design: "Móveis novos"95 e "Estante para Livros"96(escrito em parceria com Lina). Em ambos as imagens das próprias peças ilustram o texto que discorre sobre a simplicidade das formas, a adequação ao clima e ao modo de vida local, incentivando assim a alteração e a formação do gosto burguês pautado até então por uma produção local artesã de "estilos importados".

Habitat também dará espaço para a produção de arquitetura que Palanti desempenhará com destaque no Brasi $^{97}$, entre os quais edifícios verticais de uso misto e de apartamentos localizados na região central e um cinema; um conjunto de obras que expressa as alterações urbanas que São Paulo vinha sendo palco naquele momento.

Palanti também vai desempenhar importante colaboração no MASP, figurando entre nomes como os dos pintores Lasar Segall e Roberto Sambonet, da arquiteta Lina Bo, do escultor August Zamoyski, do cineasta Alberto Cavalcanto, entre outros que constituíram o corpo docente do Instituto de Arte Contemporânea (IAC), instituição cujas atividades visavam à formação de profissionais do desenho industrial aptos a trabalhar e colaborar para o desenvolvimento da indústria local. Palanti colaborou também nos primeiros anos do Museu na organização de mostras e exposições ${ }^{98}$ ao lado de Lina, Flávio Motta e Jacob Ruchti.

Por estar sob os auspícios do Muse $u^{99}$ há uma reincidência de nomes entre o grupo que colabora na revista

\footnotetext{
95 “Móveis Novos; projetos de Lina Bo Bardi e Giancarlo Palanti, arquitetos", Habitat, São Paulo, nº 1, out./dez. 1950, p. 53-9.

${ }^{96}$ B0, Lina; PALANTI, Giancarlo. "Estante para livros", Habitat, São Paulo, nº 2, jan./mar. 1951, p. 32.

97 "Edifício em São Paulo." Habitat, São Paulo, n 3, abr./jun. 1951, p. 23-24; "Prédio de Apartamentos". Habitat, São Paulo, n¹0, jan./mar. 1953, p. 19-24; "Um cinema em São Paulo". Habitat, São Paulo, nº 6, jan./mar. 1952, p. 64.

${ }^{98}$ Esse papel deve ser valorizado, tendo em vista 0 destacado papel que Palanti teve no desenvolvimento da museografia moderna italiana, primeiro através da montagem de stands em exposições comerciais ou políticas do período. A seguir através do Salão de Honra da VI Trienal de Milão (1936) em parceria com Edoardo Persico, Marcello Nizzoli e Lucio Fontana. SANCHES, 2002, op. cit.

${ }_{99}$ BARDI, P. M. In: Correspondência a Flávio Aquino. São Paulo, 27 de setembro de 1950.
} 
Habitat e o grupo do MASP, incluindo aí a lista que define o corpo docente do IAC. Verificam-se os nomes dos arquitetos Oswaldo Bratke e Rino Levi, que atuam na Escola do Museu e que na revista divulgam sua produção, entre residências e hospitais, sempre procurando explicitar os princípios da arquitetura moderna nela aplicado. 0 historiador de arte Wolfgang Pfeiffer, que colaborou com o Museu entre 1949 e 1959 na organização de exposições e ministrando cursos de História da Arte, na revista assume o lugar de crítico de arte, apresentado artigos sobre as novas aquisições da pinacoteca do Museu, e outros onde exerce papel crítico ao introduzir artistas, exposições e documentos, como uma carta de Mario de Andrade a Lasar Segall. 0 cineasta Alberto Cavalcanti, que exerceu importante papel na Companhia Cinematográfica Vera Cruz e que durante 0 ano 1949 realizará no Museu palestras sobre cinema, em Habitat aparecerá abordando questões acerca do cinema nacional e outras de teor técnico. Também como colaborador figura o cenógrafo Ruggero Jacobbi, que em Habitat dedicou-se a artigos críticos com foco na produção do teatro e do cinema nacional, e, no MASP, participou do Seminário de Cinema, do Centro de Estudos Cinematográficos, e ainda ministrou dois cursosconferências: "De Ibsen a Sartre", sobre a história do teatro contemporâneo e "Evolução paralela da pintura e da música moderna”. 0 arquiteto Jacob Ruchti, integrante do corpo docente do IAC na cadeira de Composição, tem seu trabalho para a Exposição Agrícola divulgado na revista e ainda assina o importante artigo sobre a inauguração e as intenções do Instituto.

Outro colaborador importante, Flavio Motta aparece sempre ao lado de Lina organizando a publicação. Sua presença constante na produção da revista leva Hossaka a afirmar que Habitat era uma revista feita a seis mãos ${ }^{100}$ : duas de Lina, duas de Bardi e as outras duas de Flávio Motta. Como já apresentado neste trabalho, Motta desempenha papel especial em Habitat, levando-0 a assumir a direção da revista nas quatro edições em que Lina e Pietro se ausentam do Brasil para excursionar com o acervo da Pinacoteca do Museu pela Europa.

Flávio Motta, quando passa a trabalhar em Habitat, já havia dirigido com Ciro Mendes, Clovis Graciano e Cláudio Abramo o jornal Artes Plásticas, lançado em agosto de 1948. Apesar do desenvolvimento do território artístico e cultural que São Paulo vinha sofrendo, este foi, segundo relata Neves, um dos primeiros veículos destinado somente às artes plásticas, o qual tentou suprir parte desta demanda, na medida em que cobria, divulgava, criticava, comentava o que ocorria em São Paulo. ${ }^{101}$

Segundo seus relatos, Flávio Motta, recém-bacharel em Pedagogia pela Faculdade de Filosofia, Ciências e

\footnotetext{
100 Afirmação feita por Luis Hossaka a esta autora. (ver ANEXO 4).

${ }^{101}$ NEVES, 2005. op. cit.
} 
Letras da USP, em 1947, conhece o casal Bardi através de Quirino da Silva, artista responsável pela criação do Salão de Maio e que como jornalista exercia a crítica de arte em São Paulo aproximando-se assim dos seus bastidores. A relação com Quirino leva Flávio Motta a iniciar o trabalho como assistente de Pietro antes mesmo da fundação do Museu de Arte. A colaboração de Motta na revista se faz paralela às intensas atividades que desempenha no MASP, onde além de assistente de Bardi, participa da montagem de exposições e leciona nos cursos de História da Arte. A "entrega" pela nascente instituição e o envolvimento pelos projetos de Bardi fica evidente no relato de Motta sobre as atividades na Rua 7 de Abril, entre o Museu e a revista.

Em Habitat Motta aparece a partir do sexto número (1952), com o artigo "Verde em São Paulo", em que discorre sobre a necessidade da vegetação na cidade e divulga o curso de "ajardinagem" no Museu. A partir daí, passa a assinar diversos artigos sobre arte e arquitetura, com destaque aos que debatem a importância do estudo e preservação da arquitetura art nouveau em São Paulo, subjugado ao Barroco. Intensifica suas atividades a partir da edição de $n^{0} 11$, período em que a revista já se encontra sob sua direção.

Outra figura que teve papel fundamental na revista foi 0 arquiteto Abelardo de Souza. Carioca, cursou uma Escola Nacional de Belas Artes (1926-1932), ainda com ensino academicista, e ali assistiu as discussões acerca dos rumos da arquitetura brasileira ${ }^{102}$ que foram fundamentais para formar a primeira geração de arquitetos modernos. Mudou-se para São Paulo em 1939, onde continua aqui uma produção marcada por características da "arquitetura moderna carioca" e a partir de 1945 inaugura escritório com Hélio Duarte e Zenon Lotufo. Abelardo também esteve envolvido com importantes instituições antes de colaborar com a revista: a vice-presidência do IAB-SP entre 1947 e 1949 e como professor assistente na FAU/USP a partir de 1948 (até 1978) ${ }^{103}$, portanto, no momento em que a revista Habitat é lançada Abelardo já ocupa papel de destaque no meio arquitetônico paulistano ${ }^{104}$, com uma prática que "(...) assinalava uma convicção pelo moderno que seus colegas paulistas - como Eduardo Kneese de Mello ou Oswaldo Bratke, da mesma geração - não sustentaram no início de suas carreiras"105.

${ }^{102}$ As discussões fazem referências à reforma acadêmica proposta por Lúcio Costa no momento que dirigiu a ENBA em 1931, e na criação da Universidade do Distrito Federal em 1935, sob orientação de Anísio Teixeira. Marcam esse período também as visitas ao Brasil de Le Corbusier em 1929 e de Frank Loyd Wright em 1931, ocasião na qual fazem conferências aos estudantes da ENBA.

${ }^{103}$ CONSTANTINO, Regina Adorno. A obra de Abelardo de Souza. São Paulo, 2004. Tese (Mestrado) - Faculdade de Arquiterura e Urbanismo, USP.

${ }^{104}$ Ver histórico da produção do arquiteto em FERRAZ, Geraldo. "Novos Valores da Arquitetura Brasileira: Abelardo Riedy de Souza." Habitat, São Paulo, nº 39, 1957, p. 2-21. Ver, também, SOUZA, Abelardo Riedy. Arquitetura no Brasil: depoimentos, São Paulo: Diadorim/Edusp,1978.

105 SEGAWA, Hugo. Disseminando a linguagem arquitetônica carioca em São Paulo. Projeto, nº 105, São Paulo, 1987, p. 143. 
É com essa convicção que Abelardo assume a tarefa, ao lado de Lina e Pietro, de difundir os princípios da arquitetura moderna, já brasileira, que exerce e que procura defender nas páginas de Habitat. Além de ter suas obras divulgadas pela revista ${ }^{106}$ Abelardo é autor de artigos ${ }^{107}$ de importante caráter crítico, entre os quais destacamos "Nossa arquitetura", publicada na edição de $n^{0} 2$ que, com 0 artigo "Bela criança" de Lina (impresso na página imediatamente anterior), podem ser vistos como uma das mais contundentes defesas da arquitetura que Habitat se propunha a divulgar: uma "arquitetura artisticamente social" em que a verdade construtiva de meios e de fins estaria acima de qualquer regra ou Escola, em que 0 compromisso social e 0 papel transformador garantiam seu valor.

É importante notar que Abelardo irá a partir da extinção do cargo de Diretor Geral, na edição de $n^{0} 15$ (março/ abril 1954), passar de colaborador eventual em Habitat para o cargo de Diretor de Arquitetura - novo cargo que com a Direção de Artes Plásticas marca a descentralização da direção - no qual permanece entre maio de 1954 e outubro de 1955, contemplado pelas edições de $n^{0} 16$ a 24, quando sai devido ao acumulo de funções na Universidade.

0 jornalista Geraldo Ferraz, um dos primeiros críticos de arte modernista a atuar profissionalmente na imprensa paulista, será o substituto de Abelardo de Souza a partir da edição de $n^{0} 25$ (novembro/dezembro de 1955) na Direção de Arquitetura de Habitat. Ferraz, graças à relação que estabeleceu com o casal "Tarsila e Oswald" que 0 aproximou de várias personalidades do modernismo paulista, iniciou sua atuação como crítico de arte a partir de 1929 na imprensa diária. Como já dito, a ausência de publicações e críticos especializados, fazia dos jornais o principal órgão para os críticos divulgarem suas opiniões e análises, cujo conhecimento era adquirido principalmente ao longo da atividade de crítico.

Em Habitat, Ferraz, que permanece como Diretor de Arquitetura ao longo de 59 edições, até o fim da revista em 1965, colaborou com artigos também na fase inicial ${ }^{108}$ da revista. Neste período, assina alguns artigos em

106 Ver artigos: "Projeto de Piscina de Abelardo de Souza", Habitat, São Paulo, nº 2, p. 12; "Prédio de apartamentos em São Paulo", Habitat, São Paulo, n 7, p. 18; "Prédio Nações Unidas", Habitat, São Paulo, no 12, p. 10; e "Um centro esportivo", Habitat, São Paulo, nº 12, p. 28.

107 Ver artigos: "Nossa arquitetura", em Habitat, São Paulo, ñ 2, p. 4; "Programa de melhoramentos para São Paulo", Habitat, São Paulo, nº 2, p.14; "Planos", Habitat, São Paulo, n² 2, p. 15; "IV Congresso Brasileiro de Arquitetos", em Habitat, São Paulo, no 14, p. 23.

${ }^{108} \mathrm{~A}$ partir da saída de Lina e Bardi de Habitat, nota-se o fim do compromisso com o MASP e do projeto a eles atrelados. A presença de Abelardo de Souza, com importantes laços pessoais e intelectuais com o casal, na Direção de Arquitetura após a saída do casal pode ser visto como um período de transição entre a revista "Habitat de Lina e Pietro" e a "Habitat de Geraldo Ferraz", rompendo com o recorte inicial - divulgar a produção de arquitetura de São Paulo, alargando-se os limites até a produção internacional. Outros aspectos serão levantados adiante. 
Habitat ao mesmo tempo que exerce importante papel na construção de uma historiografia oficial da arquitetura moderna brasileira, com destaque para o livro sobre 0 arquiteto Gregori Warchavick. Nos primeiros anos de Habitat sua colaboração restringe-se ao artigo "Reportagem do Recife", na edição de nº 3, e "Urbanização na praia de Pernambuco", na edição de $n^{014}$, onde discorre longamente sobre o projeto de Henrique Mindlin para a urbanização da praia de Pernambuco, no Guarujá.

Também com participação em Habitat como o "proprietário" do MASP, o jornalista Assis Chateaubriand teve espaço na revista "louvando" o seu museu. Entre artigos, cuja tônica é a afirmação do valor da instituição e do rico acervo em constante expansão, figura na revista $n^{0} 20$ artigo "Agora, ou nunca mais" (janeiro/março 1951), publicado em papel especial e que aparece como um chamado para a necessidade de investimento no mercado de artes plásticas na Europa, naquele momento em baixa com o resultado da guerra. Também com 0 mesmo argumento na revista $n^{0}$ 06, 0 artigo "Obras de arte recebidas como personagens", publica o discurso de Chatô proferido no MASP na cerimônia que tornara pública as mais recentes aquisições da instituição: obras de Camile Carot, Henri Matisse e Paul Cézanne. No editorial da revista $n^{0} 13$ Chatô apresenta, em defesa do acervo do MASP que neste momento é posto em questão, o artigo escrito para o jornal francês Arts de Germain Bazin, "0 Museu de Arte de São Paulo", em que proclama o sucesso da exposição do acervo do Museu exposto no Musée de l'Orangerie de Paris.

Diferente deste editorial que introduz o "número especial" sobre o Museu que a edição de $\mathrm{n}^{0} 13$ se propõe a realizar; 0 outro, concedido a Chateaubriand na revista $n^{0} 10$ nada tem em comum com o restante da edição. 0 décimo editorial publica mais um discurso de Chatô, "Problemas educacionais", proferido por ocasião de uma reunião presidida pelo vice-presidente Café Filho em prol da criação de "uma Groton Scholl, alternada com a École de Roches" no Brasil. 0 discurso, em que Chateaubriand destaca a desproporção entre o desenvolvimento material e 0 da educação de nível secundário e superior no país, é anacrônico em relação ao restante da publicação, revelando uma possível condescendência entre os organizadores da revista e o "patrão". Situação que se repete no artigo "0 índio e o homem do planalto", que ironicamente antecede artigo "Taba Guaianases, em São Paulo", no qual divulga o projeto da superestrutura projetada por Lina e por Pier Luigi Nervi para a nova sede do Diários Associados. 0 texto escrito por Assis Chateaubriand discorre sobre a "reciprocidade" da influência entre a população aborígine que habitava o continente e o homem branco, que originaram metrópoles como São Paulo e Rio de Janeiro.

Vistos como um time, os principais colaboradores de Habitat, profissionais vindos de diversas áreas: jornalistas, 
arquitetos, artistas, historiadores, cineastas, teatrólogos etc.; assumem com sua participação uma posição afinada ao propósito da revista, ou seja, alargar, formar e, na melhor das hipóteses, transformar os conceitos de arte e cultura ainda impregnados na metrópole que São Paulo já se tornara naqueles anos. 


\section{A Arquitetura na revista Habitat}

As questões em torno da arquitetura, assim como as relacionadas ao Museu, sobressaem em relação a outras temáticas presentes em Habitat. ${ }^{1}$ Por meio de artigos teóricos e apresentação de projetos e fotografias, a revista faz a eleição de uma arquitetura que denomina artisticamente social. Logo no primeiro número de Habitat, a partir dos artigos publicados, é possível identificar que essa arquitetura não estaria vinculada a uma época ou a um movimento, mas a um espírito que a faz verdadeira e coerente com o seu tempo.

Assim, Habitat publica a arquitetura popular do Norte e Nordeste ao lado da produção da arquitetura moderna realizada em São Paulo. A aproximação dessas duas vertentes se faz pelos valores que as caracterizam ou que a elas são atribuídos: a "racionalidade", o respeito às técnicas locais, ao clima, à economia de meios e à lógica construtiva. Estes elementos são os que fundamentam a eleição da arquitetura divulgada pela revista, na qual a coerência e a sinceridade ficam acima dos elementos estéticos e plásticos que a poderiam definir. Uma arquitetura que possa ser vista como, por excelência, a expressão da vida do homem em seu tempo.

Logo nas primeiras páginas do número inaugural, num artigo dedicado às residências de autoria do arquiteto Vilanova Artigas, a revista esclarece sobre o caráter da arquitetura que deseja divulgar. Em um texto assinado por Lina Bo, aponta os valores dessa produção sem cair na fácil discussão formal e programática, comum as revistas dedicadas a essa disciplina.

“(...) A sua é uma arquitetura 'humana', ou melhor, doméstica, no sentido mais claro da palavra. Uma casa construída por Artigas não segue as leis ditadas pela vida de rotina do homem, mas lê impõe uma lei vital, uma moral que é sempre severa, quase puritana. Não é 'vistosa', nem se impõe por uma aparência de modernidade, que já hoje se pode definir num estilismos."

Na definição da arquitetura eleita, Habitat divulga uma produção que representa os conceitos de uma correta arquitetura afinada com 0 homem em seu tempo:

“(...) Hoje, após um estudo e uma avaliação conciente, Artigas chegou a certeza de que a conquista do homem contemporâneo é a consciência de si mesmo, e se uma esperança esta reservada a humanidade, ela se encontra justamente no fato de o homem saber que só pode contar consigo mesmo e com suas forças; $\mathrm{e}$ se a arquitetura é por excelência a expressão da vida do homem em seu tempo (...). A sua moral arquitetônica o levou a formas extremamente secas, ósseas, completamente independentes da paisagem que as rodeia, sinceramente humanas." 3

${ }^{1}$ Do total de 479 títulos de artigos catalogados, 163 dizem respeito à discussão de arquitetura.

2 B0, Lina. "Casas e Vilanova Artigas". Habitat, São Paulo, nº 1, p. 2.

${ }^{3}$ BO, Lina. "Casas e Vilanova Artigas", Habitat, São Paulo, n. 1, 1950, p. 2. Grifo nosso. 


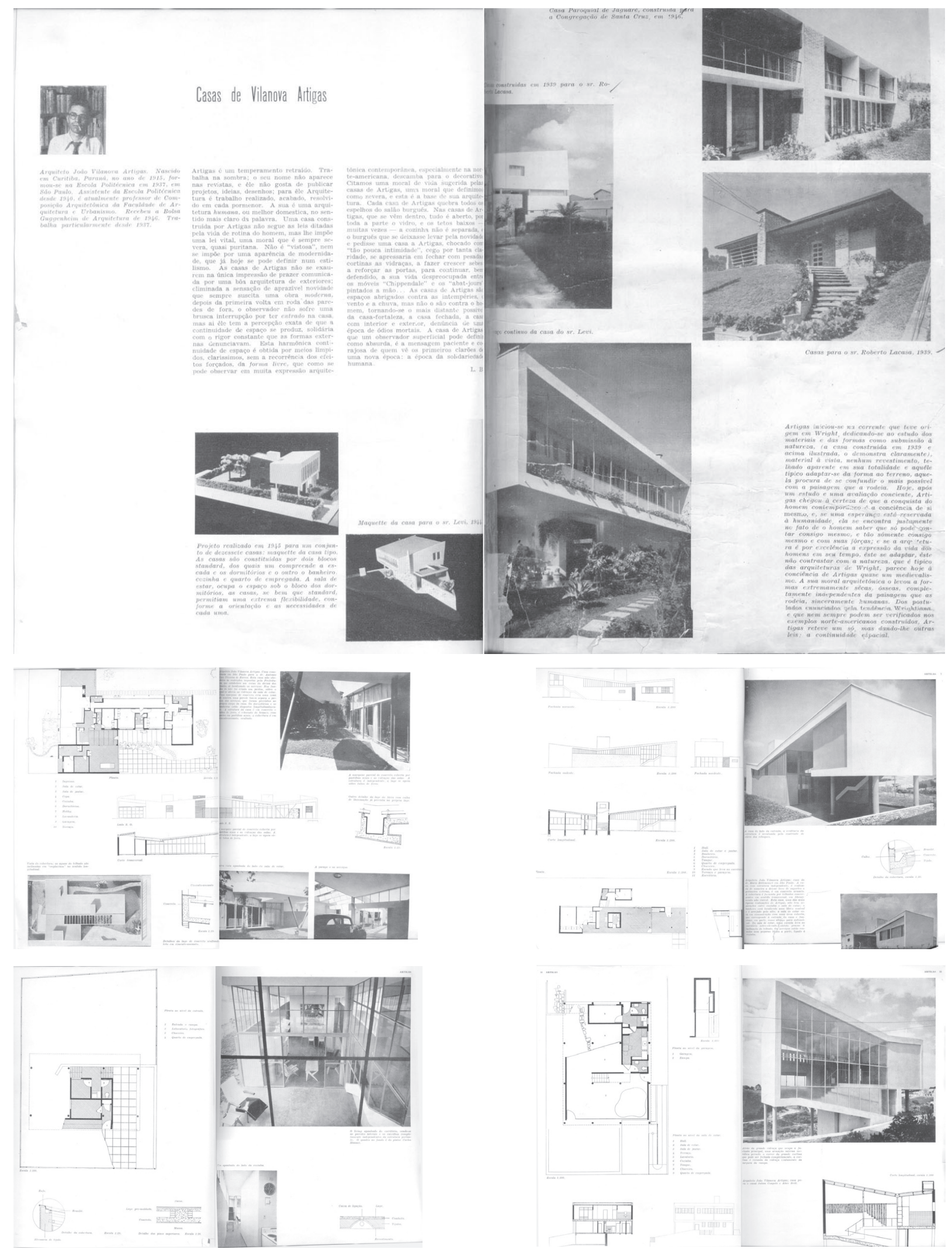

45 a 48 . "Casas de Vilanova Artigas" inaugura as primeiras páginas de Habitat com texto de Lina Bo e faz uma avaliação crítica da obra do arquiteto que representa a arquitetura a qual a revista iria se dedicar 
0 artigo delineia o percurso profissional do arquiteto pela análise de suas obras. Habitat dedica um cuidadoso e extenso artigo em que a autora apresenta 0 arquiteto e caracteriza sua personalidade profissional, ilustrada por imagens que revelam a influência de Wright presente nos primeiros trabalhos. Segue quatro projetos ricamente ilustrados: a residência para o Dr. Antônio Luiz Teixeira de Barros, a residência para o Dr. Mario Bittencourt, para o casal Julian Czapsky e Alice Brill, e a residência para o Sr. Hans Trostli.

Artigas terá espaço novamente apenas dez números depois, na edição de $n^{0} 11$ (abril/junho 1953), quando a revista divulga seu projeto vencedor para o Estádio do São Paulo Futebol Clube. A pouca freqüência desse arquiteto, cuja quantidade de obras é relevante nesse período, pode ser explicada por seu envolvimento com 0 grupo de MAM/SP4 , cujo percurso foi marcado pelo embate constante com o MASP ao qual Habitat era alinhada ${ }^{5}$.

A escolha por uma arquitetura em que os valores morais, como a racionalidade construtiva e a adequação a função estariam à frente das questões plásticas e formais se explica ao retomarmos o percurso na Itália de Pietro e Lina. 0 primeiro com um trabalho ativo na defesa da arquitetura racionalista italiana e polemista em importantes periódicos, estabeleceu relações profissionais e afetivas com personalidades do cenário internacional do movimento moderno e participou em julho de 1933 do IV Congresso do CIAM $^{6}$, onde se aproximou de Le Corbusier e Guideon. E a trajetória de Lina, que colaborou ao lado Giò Ponti e Carlo Pagani, entre outros periódicos, nas revistas Domus e Lo Stile, importantes veículos na formação da cultura arquitetônica racionalista italiana e no resgate de valores locais na reconstrução da Itália no imediato pós-guerra.

Em 1950 quando Habitat lança seu primeiro número, a arquitetura moderna brasileira já havia atravessado o Atlântico e conquistado lugar de destaque nas páginas de importantes revistas internacionais. Em 1947 Architecture D'aujourd'hui (agosto/outubro) dedicou uma edição especial a ela, publicando projetos do grupo de arquitetos cariocas, entre os quais Oscar Niemeyer, Lucio Costa, M. M. M. Roberto, Álvaro Vital Brasil, Burle Marx, Francisco Bolonha, Sérgio Bernardes.

\footnotetext{
${ }^{4}$ João Vilanova Artigas figura entre os nomes da primeira diretoria administrativa da instituição e é autor do projeto de adaptação espacial do museu no prédio dos Diários Associados cedido por Assis Chateaubriand.

${ }^{5} 0$ retorno de Artigas às páginas da revista coincide com seu rompimento com o MAM/SP após criticar no jornal Hoje 0 evento da I Bienal como "expressão da decadência burguesa", por ter sido organizada pelo museu sob 0 apoio de instituições culturais norte-americanas.

${ }^{6}$ No IV CIAM, realizado a bordo do navio Patris // na viagem entre Marselha e Atenas, foi elaborada a Carta de Atenas, a qual estabeleceu os princípios da urbanística moderna.

7 Também destacam a arquitetura moderna brasileira as revistas norte-americanas Architectural Record (1940), Architectural Forum (1943); a inglesa Architectural Review (1943), e a italiana Zodiac (1950), além de outras. Apud DURAND (1989), op.cit., p. 125.
} 
No Brasil, um número relevante de periódicos especializados já dedicava espaço a arquitetura moderna entre artigos que divulgavam outras arquiteturas de estilo, nem tão modernas assim. A revista Acrópole (São Paulo) de 1938 traz o primeiro artigo sobre o tema e em 1947 aparece o primeiro do periódico mineiro Arquitetura $e$ Engenharia. Posteriores a Habitat, dois periódicos cariocas terão como foco a arquitetura moderna brasileira: Brasil - Arquitetura Contemporânea, em 1953, e Módulo, a revista de Oscar Niemeyer, fundada em $1955^{8}$.

Nesse sentido, a seleção dos projetos e arquitetos publicados na revista Habitat difunde novos ou já consagrados valores de nossa arquitetura por meio do confronto permanente com o pensamento arquitetônico internacional, contribuindo para 0 amadurecimento do debate arquitetônico no panorama cultural brasileiro. Esse "compromisso" é declarado no editorial do primeiro número da revista, quando 0 autor reforça 0 interesse pela Arquitetura, tema ao qual o título da revista estaria também intimamente ligado.

\begin{abstract}
"Também a arquitetura já de fama mundial, será apresentada em suas mais características inovações e soluções mais afins com a civilização tropical. 'Habitat' significa ambiente, dignidade, conveniência, moralidade de vida e, portanto espiritualidade e cultura: é por isso que escolhemos para título desta nossa revista uma palavra intimamente ligada a arquitetura, à qual damos um valor e uma interpretação não apenas artística, mas uma função artisticamente social." ${ }^{9}$
\end{abstract}

E ao atribuir-Ihe uma "função artisticamente social", Habitat elege neste momento uma arquitetura como tema, a qual irá divulgar e polemizar, uma arquitetura em que a racionalidade e a simplicidade se alinham a vida cotidiana. Por esse recorte, a revista dedicará grande espaço a uma arquitetura moderna brasileira, principalmente aquela produzida em São Paulo e fundamentada em princípios sociais, os mesmos princípios que destaca na arquitetura popular realizada no interior do Brasil.

Na definição dos valores dessa arquitetura popular, também na primeira publicação de Habitat, 0 artigo "Amazonas: o povo arquiteto" traz imagens de Roberto Maia que retratam desde as ruas líquidas de Manaus até a casa do operário no Espírito Santo, e um texto de Lina Bo, pelos quais é possível perceber a mesma preocupação social colocada ao apresentar a produção moderna de Artigas; uma crítica social que caracterizará este período da revista:

\footnotetext{
${ }^{8}$ Vale destacar entre as publicações do período, a antecessora Revista da Diretoria de Engenharia, com o primeiro número em julho de 1932, um periódico da repartição oficial da Prefeitura do Distrito Federal responsável pelas obras públicas na cidade do Rio de Janeiro. Apesar de tratar-se de uma revista técnica de engenharia civil, foi precursora na divulgação de arquitetura moderna no Brasil e pioneira no trato de assuntos urbanísticos. In: SEGAWA, H. M., Arquiteturas no Brasil, 1900-1990, São Paulo: Editora da Universidade de São Paulo, 2002, p. 81.

9 "Prefácio". Habitat, São Paulo, n. ${ }^{0}$ 1, 1950, p. 1. Grifo nosso.
} 

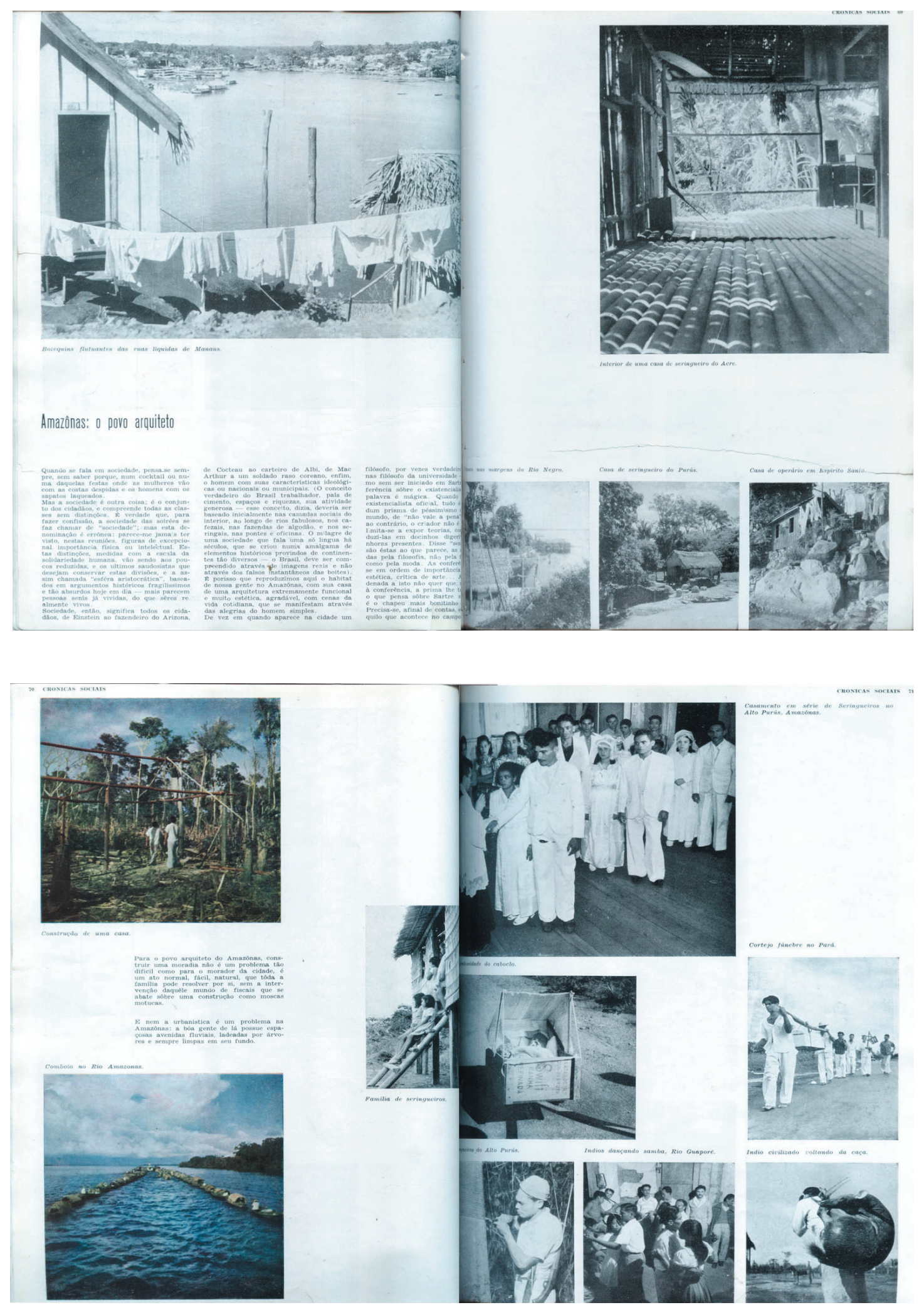

49 e 50 . Em "Amazonas: o povo arquiteto", Habitat desvenda o interior do país e exibe sua riqueza através da valorização da cultura popular. 
"Quando se fala em sociedade, pensa-se sempre, sem saber porque, num cocktail ou numa daquelas festas onde as mulheres vão com as costas despidas e os homens com os sapatos laqueados.

Mas sociedade é outra coisa; é o conjunto dos cidadãos, e compreende todas as classes sem distinções. (...)

Sociedade, então, significa todos os cidadãos, de Einstein ao fazendeiro do Arizona, de Cocteau ao carteiro de Albi, de Mac Arthur a um soldado raso coreano, enfim, o homem com suas características ideológicas ou nacionais ou municipais. 0 conceito verdadeiro do Brasil trabalhador, país de cimento, espaços e riquezas, sua atividade generosa - esse conceito, dizia, deveria ser baseado inicialmente nas camadas sociais do interior, ao longo dos rios fabulosos, nos cafezais, nas fazendas de algodão, e nos seringais, nas pontes e oficinas. 0 milagre de uma sociedade que fala uma só língua há séculos, que se criou num amalgama de elementos históricos provindos de continentes tão diversos (...). É por isso que reproduzimos aqui o habitat de nossa gente no Amazonas, com sua casa de uma arquitetura extremamente funcional e muito estética, agradável, com cenas da vida cotidiana, que se manifestam através das alegrias do homem simples (...)". ${ }^{10}$

Ao lado dessa arquitetura regida por uma função social, Habitat dará espaço a artigos de caráter histórico voltados para a análise da arquitetura do barroco e também do art nouveau. Desta forma, aproxima, como prometido no editorial inaugural, os tempos numa só época, rompendo com os limites que separam os conhecimentos.

Como exemplo, a defesa da arquitetura art nouveau levantada por Flávio Motta nas páginas de Habitat. Defesa que já se justificaria pela ausência no livro Brazil Builds dessa produção. A fim de facilitar o "nascimento" da arquitetura moderna e seu vínculo com o passado, o livro que aparece como o primeiro levantamento da produção nacional entre 1652-1942, dedica amplo espaço para a produção colonial e omite a arquitetura eclética e art nouveau que marcaram o final do século XIX e o início do XX. Portanto Habitat faz uma revisão historiográfica com o resgate do art nouveau como precursor da arquitetura moderna, pela sua pesquisa de materiais ligados a novas formas de expressão e pela aproximação com as artes aplicadas, temas estes que seriam resgatados no âmbito da política cultural do Museu de Arte, da qual a revista Habitat constituía veículo importante.

No conjunto de artigos sobre 0 art nouveau podemos identificar uma campanha pela preservação dos últimos exemplares dessa produção ainda existente em São Paulo, as quais o IPHAN não dedicava a devida atenção ao superestimar o estudo do Barroco colonial. Neste sentido aparece a sugestão da revista de instaurar um Museu do estilo floreal em uma casa ameaçada pela especulação imobiliária na rua Marquês de Itu. Motta em um artigo ilustrado com diversas imagens da Vila Penteado, neste momento sede da Faculdade de Arquitetura e Urbanismo da Universidade de São Paulo, aponta o art nouveau como representante da libertação dos antigos estilos:

${ }^{10}$ Atribuído a B0, Lina. "Amazonas: o povo arquiteto". Habitat, São Paulo, nº 1, 1950 p. 68. Grifo nosso. 

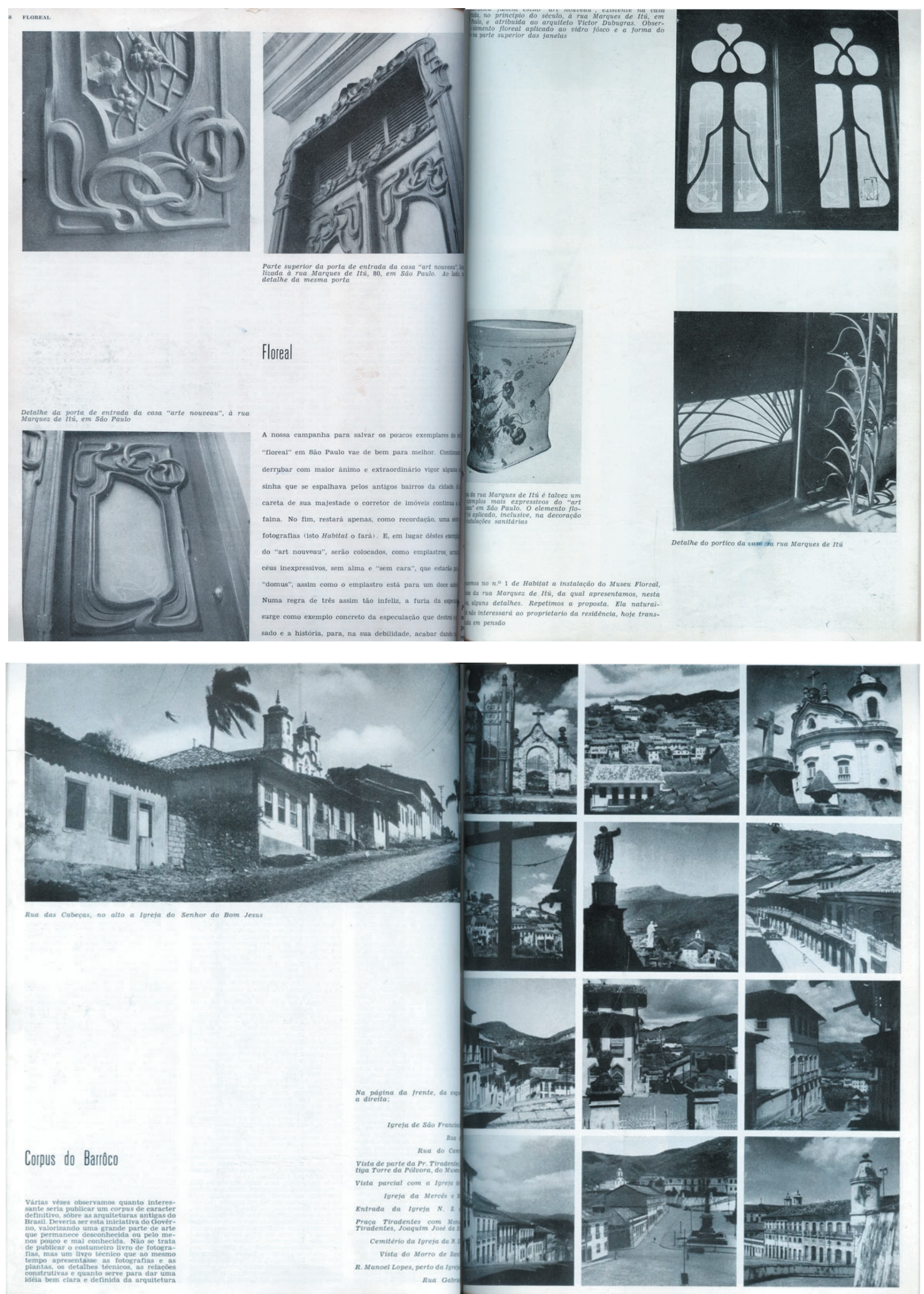

51. A valorização do art nouveau em Habitat é feita por Flávio Motta através da revisão de sua importância para a constituição da arquitetura moderna no Brasil.

52. "Corpus do Barroco" trata da necessidade da documentação e conservação da arquitetura e da arte do Barroco brasileiro. A preocupação com a preservação da memória e da história é uma constante em Habitat. 
“Embora seja apenas a manifestação do gosto de cincoenta anos atrás, o 'art nouveau' representa um período sugestivo no plano da nossa tradição artística, porque foi um estilo que assinalou o primeiro movimento de libertação daquelas soluções 'neo-góticas' e 'neo-renascentistas', 'pseudo-barrocas', e até 'pseudocoloniais' que proliferavam e ainda proliferam entre nós. 0 'art nouveau' representa uma etapa necessária no desenvolvimento da nossa arquitetura que atingiu, modernamente, a verdadeira consagração no plano internacional." 11

E cita Nikolaus Pevsner ao apresentar a primeira residência art nouveau de Victor Horta em Bruxelas, em 1893, "nasceu improvisadamente, sem premissas arquitetônicas, já completo e perfeito, num edifício que revela, nitidamente, a intenção de separá-lo dos estilos anteriores".

A recolocação do art nouveau como precursor do Moderno aparece na revista quando Flávio Motta demonstra 0 vínculo existente entre eles, 0 qual teria tornado possível sua realização. Essa tese a respeito do significado do art nouveau no Brasil ${ }^{12}$ tem início nas páginas da revista: um movimento que teve no Liceu de Artes e Ofícios (fundado em 1873) seu centro de irradiação em São Paulo e que representou o enriquecimento da sociedade cafeeira e o início da industrialização. Marcou a transição entre o "historicismo" e o "modernismo", incentivando as faculdades inventivas individuais e estimulando 0 artesanato e as artes aplicadas; no entanto, um movimento que não compreendeu com exatidão as verdadeiras possibilidades da máquina como instrumento de cultura.

Também em relação a arquitetura histórica há artigos assinados por Bardi que discorrem sobre a produção do Barroco no Brasil, principalmente aspectos da arquitetura religiosa, que ele chama de "barroco colonial" e na qual destaca o caráter espontâneo. Em "Problemas do Barroco: a religião e a curva”"13, Bardi apresenta questões que vão da arquitetura barroca até a arquitetura racionalista, passando por Lodoli, mais uma vez honrando 0 compromisso de Habitat de "fundir os tempos numa só época; sem a baliza das classificações, dividindo 0 antigo do assim chamado moderno". É importante lembrar que na mesma publicação, páginas antes, Lodoli é citado em artigo que introduzirá as cadeiras realizadas por Lina e Palanti no Studio de Arte Palma, por meio do qual são apontados aspectos da teoria do frei italiano que estabelece a relação entre material e forma, tema que perpassa todo o percurso arquitetônico racionalista ${ }^{14}$.

\footnotetext{
${ }^{11}$ MOTTA, Flávio. "São Paulo e o 'art nouveau'”, Habitat, São Paulo, no 10, jan./mar. 1953, p. 3.

12 Mais tarde, em 1957, Flávio Motta publicará "Contribuição ao estudo do "Art nouveau”" no Brasil", Tese defendida como provimento de cátedra na Faculdade de Arquitetura e Urbanismo da Universidade de São Paulo para a cadeira de Historia da Arte e Estética.

${ }^{13}$ BARDI, P. M.“Problemas do Barroco: a religião e a curva”, Habitat, São Paulo, nº 1, 1950, p. 80.

${ }^{14}$ Um exemplar do tratado de Andréa Memo, discípulo de Lodoli e divulgador de suas idéias, se encontra na Biblioteca do Masp para consulta.
} 


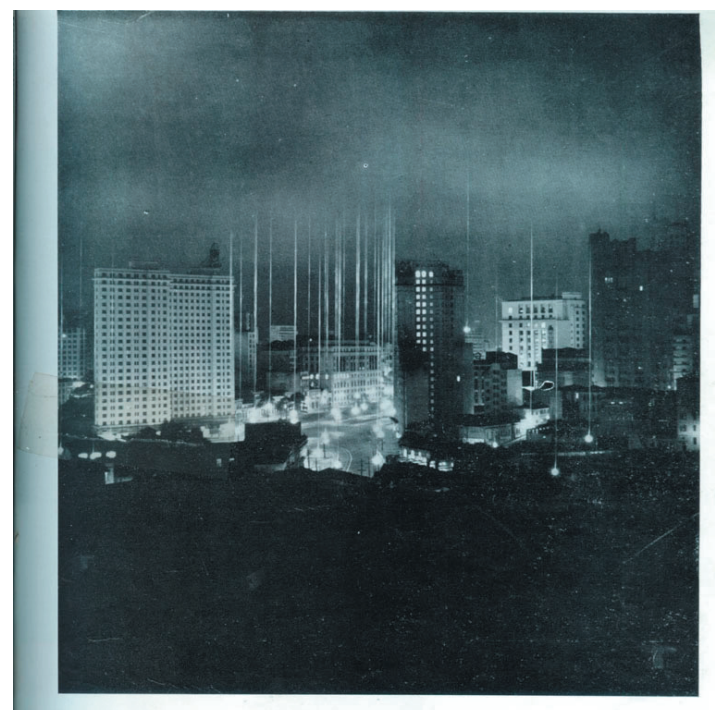

Do pequeno an grande, numa corrida
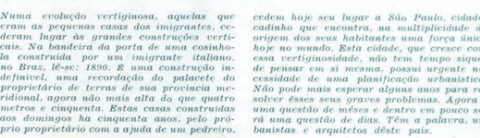

53. A falta de planejamento e o crescimento desenfreado de São Paulo.
Há ainda nas páginas de Habitat a discussão em torno dos problemas urbanísticos, fruto do acelerado crescimento de São Paulo, da falta de planejamento e de condições dignas à população de baixa renda.

"Numa evolução vertiginosa, aquelas que eram as pequenas casas de imigrantes, cederam lugar às grandes construções verticais. (...) Estas casas construídas aos domingos há cinqüenta anos, pelo próprio proprietário com a ajuda de um pedreiro, cedem hoje seu lugar a São Paulo, cidade-cadinho que encontra, na multiplicidade da origem dos seus habitantes uma força única no mundo. Esta cidade, que cresce com esta vertiginosidade, não tem tempo sequer de pensar em si mesma, possui grande necessidade de uma planificação urbanística. Não pode mais esperar alguns anos para resolver esses seus graves problemas. Agora é uma questão de meses e dentro em pouco será uma questão de dias. Tem a palavra, urbanistas e arquitetos deste país." 15

Dedicar-se a direção de uma revista de artes no Brasil onde a arquitetura moderna teria destaque não parece tarefa fácil, mesmo tendo Bardi e Lina realizado com brilhantismo esta tarefa na Itália. É no desafio de fazê-la que se lançam "oficialmente" entre os "consagrados" ao publicar seus próprios feitos entre a divulgação da produção de arquitetura local. 0 casal parece buscar a garantia de sua inserção em um pequeno grupo já ativo na sociedade paulistana e fazer-se reconhecidos por esta própria sociedade que buscava legitimar.

Lina com sua produção, seja no campo da arquitetura - com o projeto de adequação do Edifício Guilherme Guinle dos "Diários Associados" para a sede do Museu de Arte ou para o Museu de São Vicente -, seja no campo do desenho industrial - na produção de móveis no Studio de Arte Palma em parceria com Giancarlo Palanti -, procura marcar sua presença ativa dentre os que colaboravam para o fortalecimento da arquitetura moderna em São Paulo.

A divulgação do nome de Lina, fortemente vinculado ao Museu, e de suas produções em diversos artigos nos faz ver a revista também como um instrumento de afirmação e poder, em uma sociedade onde a tradição quase sempre vinha antecipada à competência.

15 “Do pequeno ao grande, numa corrida”, Habitat, São Paulo, nº 1, 1950, p. 65. 


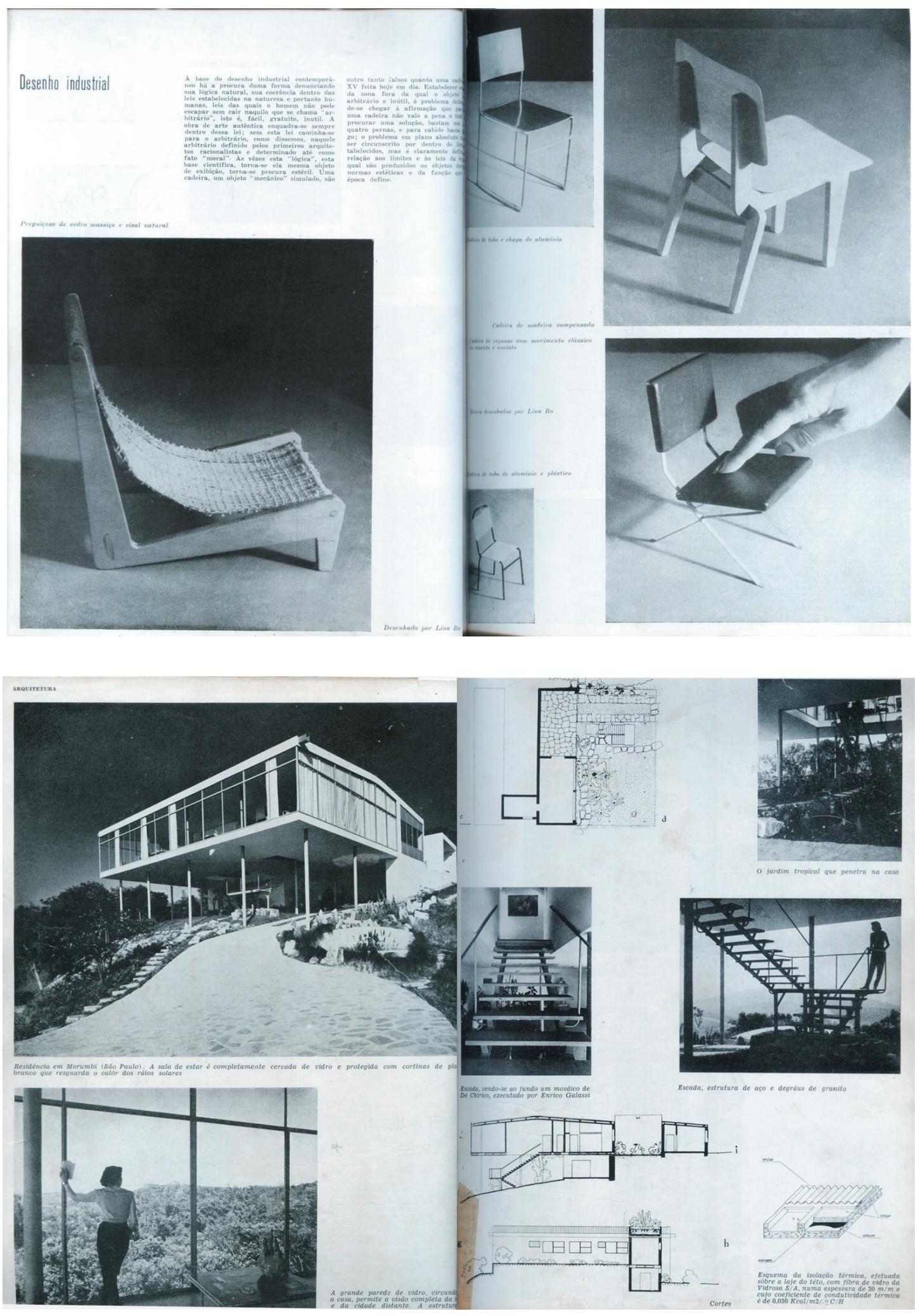

54 e 55. "Desenho Industrial" e "Residência no Morumbi", respectivamente, trazem para Habitat as realizações de Lina Bo no campo do desenho industrial e da arquitetura. Uma produção que nesse momento é marcada pelo racionalismo estrutural e simplicidade formal, e que revelam uma coerência entre 0 discurso e a prática da arquiteta. 
A fim de afastar o risco da autoconsagração, Habitat publica o artigo elogioso originário da revista Interiors sobre o projeto da residência da arquiteta Lina Bo Bardi no Morumbi. A "palavra estrangeira" neste momento aparece como moeda de autenticidade, de competência e valor dos feitos dos diretores da revista ${ }^{16}$; pois como vimos, o reconhecimento da crítica internacional também foi utilizado para "garantir" o valor das obras da Pinacoteca do Museu de Arte, então sob suspeita de fraude.

Outra característica da revista que já foi apontada é a opção pela divulgação da arquitetura realizada em São Paulo. Neste sentido poderíamos aceitar como justificativa, questões "técnicas", como a dificuldade de comunicação relacionada a distância que levaria a priorizar a produção local a fim de facilitar o processo. Mas são as questões "estratégicas" que, acreditamos, tenham sido determinantes. Dentre elas, a decisão de Niemeyer de "ficar no seu lugar"17, que romperia com a possibilidade do intercâmbio com um dos maiores representantes da arquitetura moderna brasileira.

Assim, fica para Habitat a produção contemporânea realizada em São Paulo, centro difusor na década de 1920 da arquitetura moderna no Brasil, quando a capital paulista fora palco de acontecimentos que "semearam" seu nascimento.

A disputa pelo reconhecimento de "locus da fermentação" da arquitetura moderna brasileira teve lugar na historiografia oficial realizada na primeira metade do século passado. Representantes de São Paulo e do Rio de Janeiro reivindicaram para si, a partir de acontecimentos e realizações, 0 título de pioneiros da arquitetura moderna no Brasili18 que até 0 início dos anos 50 era creditado aos cariocas.

\footnotetext{
${ }^{16}$ Como já descrito, durante 0 ano de 1953, Bardi e Lina saem em excursão pela Europa realizando exposições nas mais importantes instituições do velho continente a fim de confirmar, pelo reconhecimento internacional, o valor das obras da Pinacoteca do Museu de Arte postas em questão publicamente pela sociedade local. A direção de Habitat, neste momento a cargo de Flávio Motta, utiliza-se inúmeras vezes de artigos pubicados anteriormente em periódicos estrangeiros para divulgar a positiva crítica internacional.

${ }^{17}$ Refere-se ao texto escrito por Lina Bo (1978), anteriormente citado, o qual acena para o período que antecede a publicação de Habitat, e veiculava a idéia de uma revista de arquitetura que estabelecesse uma ponte da produção Rio-São Paulo, e haveria co-direção de Oscar Niemeyer.

${ }^{18}$ Entre os que defendem a causa carioca esta o pioneiro Philip L. Goodwin (1943), com Brazil Builds: Architecture new and old 1652-1942, que influenciou durante muito tempo a leitura da produção do período e, seguindo a mesma linha, Henrique Mindlin (1956) com Modern Architecture in Brazil. Vale ainda destacar a polêmica realizada a partir da publicação, em 1947, de "Arquitetura Contemporânea no Brasil" pela revista Anteprojeto dos estudantes da Faculdade Nacional de Arquitetura, que dedica a Lúcio Costa o título de "mestre da arquitetura tradicional e pioneiro da arquitetura contemporânea no Brasil"; contestado por Geraldo Ferraz, que o reivindica a Warchavchik no artigo "Falta o depoimento de Lúcio Costa", publicado no Diário de São Paulo (1\%/2/1948). A resposta de Costa, "Carta depoimento", foi publicada em 0 Jornal (14/3/1948). Ambos os textos estão reproduzidos em Lúcio Costa, Sobre Arquitetura, p. 119-128.
} 
Em defesa da causa paulistana em 1956, Geraldo Ferraz publicara Warchavchik e a introdução da nova arquitetura no Brasil: 1925 a 1940. 0 livro publicado pelo MASP, com prefácio de Pietro Maria Bardi, assimila uma série de conceitos que Ferraz já vinha expondo em artigos publicados em Habitat ${ }^{19}$. Nele Ferraz aponta Warchavchik e Flávio de Carvalho como os pioneiros da arquitetura moderna, propondo, como indica Martins (1988), um esquema de análise e uma reconstituição da trama que se colocam nas antípodas daqueles que vinham se afirmando através de Goodwin e Mindlin.

Ferraz caracteriza o movimento moderno na arquitetura como um fato internacional, fruto dos novos programas socialmente colocados, das novas disponibilidades e recursos técnicos e materiais e do "estado de espírito moderno". Neste sentido, o manifesto de Warchavchik "Acerca da Arquitetura Moderna", publicado em novembro de 1925 pelo Correio da Manhã do Rio de Janeiro, procuraria romper com a produção eclética de arquitetura, dentro do quadro de profundas mudanças que São Paulo vinha sendo palco a partir da primeira guerra.

A fim de afirmar o papel da arquitetura moderna realizada em São Paulo, o mesmo manifesto aparece publicado em Habitat $\mathrm{n}^{0} 2$ 2, no artigo intitulado "Documentos da arte brasileira"; mesma publicação em que é divulgado 0 único projeto de Warchavchik durante o período aqui estudado, uma pequena residência no Guarujá. A revista apresenta o documento como a palavra que lançou uma nova concepção arquitetônica:

"Este é o primeiro documento escrito no Brasil, defendendo as idéias constantes, nesse mesmo ano na Bauhaus, de Dessau, do primeiro ‘Bauhausbucher', de Walter Gropius, 'Internationale Architektur', e o pavilhão de 'L'Esprit Nouveau', da Exposição de Paris, quando Le Corbusier dava a primeira demonstração de suas idéias em arquitetura, num certame internacional. (...)"20

Na publicação anterior, Habitat n 1, uma nota ilustrada nas colunas de "Alencastro" já havia marcado posição sobre o pioneirismo paulista pela divulgação da publicação do livro, em fase de finalização, segundo o texto, sobre a obra do arquiteto Warchavchik. A nota apresenta um livro que cobre um período "até agora ausente das publicações especializadas, tanto publicadas no país como no exterior, ou seja, o período de introdução da arquitetura moderna em São Paulo e no Rio, de 1928 a 1936, com as construções de Warchavchik, oferece um interesse incomum, pelo registro dos primeiros passos da renovação operada no país, neste setor" (grifo nosso).

\footnotetext{
${ }^{19}$ No ano de 1956, Ferraz passa a publicar em Habitat uma série intitulada "Individualidades na história da arquitetura no Brasil”, a qual se dedica à produção de um arquiteto. Entre eles terá espaço Gregori Warchavchik, em Habitat, nº 28.

${ }^{20}$ Habitat, São Paulo, nº 2. jan./mar. 1951, p. 51.
} 

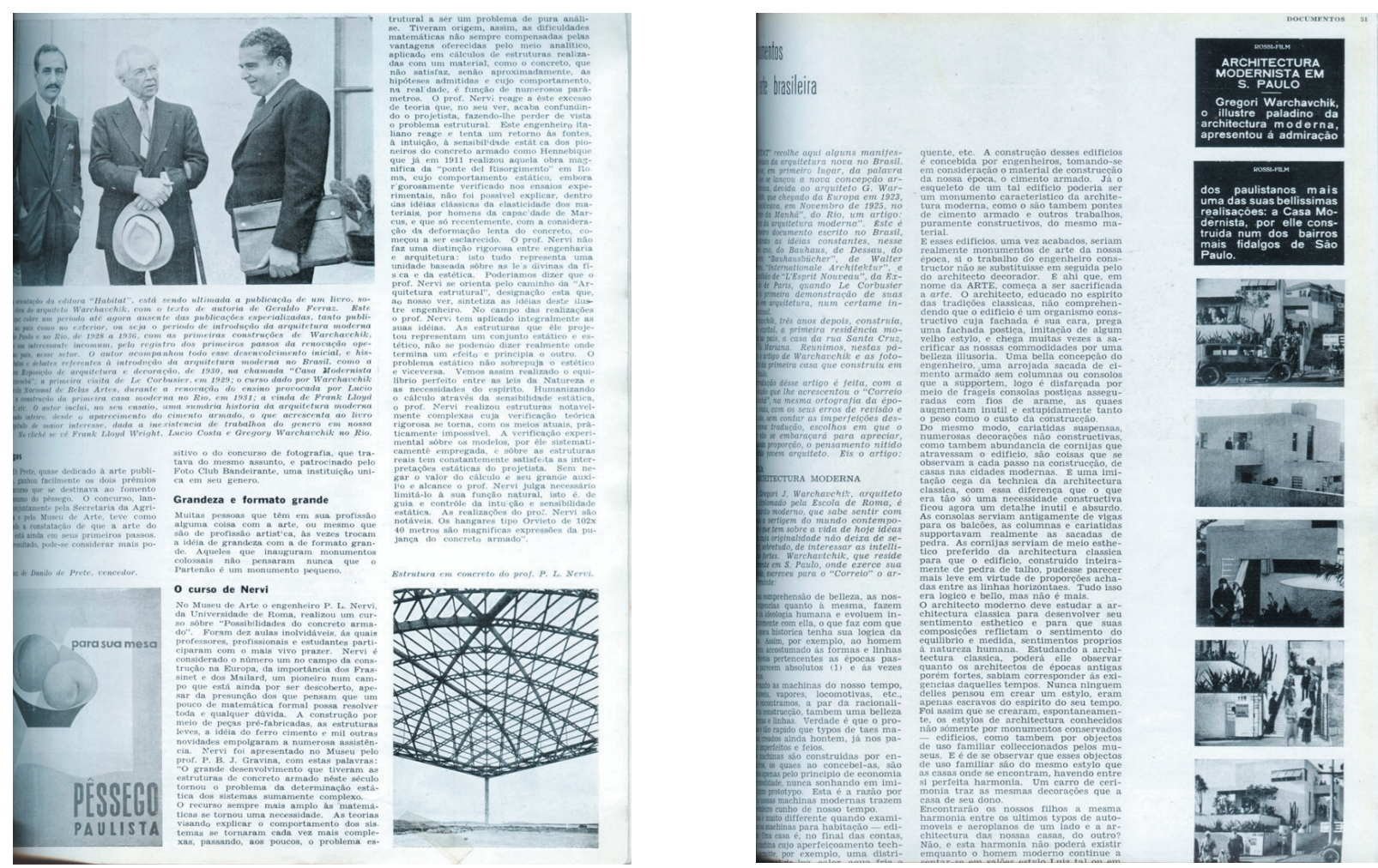

56 e 57 . A valorização do papel "precursor" que Warchavick representaria para a arquitetura moderna no Brasil, destacase em Habitat através da divulgação do livro sobre a obra do arquiteto, escrito por Geraldo Ferraz ; e na publicação do manifesto "Acerca da Arquitetura Moderna", escrito em 1925 para o Correio da Manhã do Rio de Janeiro.

No entanto, apesar do recorte territorial dos projetos publicados, a arquitetura realizada em São Paulo e divulgada em Habitat é antes de tudo uma arquitetura moderna brasileira, que busca, através de características próprias, ser também instrumento do projeto modernizador e desenvolvimentista do país que marcou o governo de Getúlio Vargas ${ }^{21}$.

No segundo exemplar da revista uma nota introdutória ao texto publicado de Abelardo de Souza intitulado "Nossa arquitetura", assume a arquitetura brasileira como o tema que constitui a base principal de Habitat; 0 que se altera a partir da publicação do número 16 (maio/junho1954), quando Habitat passa sistematicamente a publicar projetos internacionais, ao lado da produção nacional.

"Habitat promove um estudo sobre a arquitetura brasileira, e para este fim pedirá as pessoas mais responsáveis seu parecer sobre o tema que constitui a base principal de nossa revista (...)". ${ }^{22}$

Correspondente ao período inaugural da revista, o aqui eleito para a análise, colocar, por meio do discurso

${ }^{21}$ Sobre o papel da arquitetura moderna neste processo e sua relação com o Estado, ver MARTINS. (1987), op. cit.

${ }^{22}$ SOUZA, Abelardo, "Nossa Arquitetura", Habitat, São Paulo, nº 2. jan./mar. 1951, p. 4. (Grifo nosso) 
impresso, as intenções de Habitat. A direção, conduzida por Lina Bo e P. M. Bardi²3, caracteriza especialmente a publicação como palco de afirmação da já "talentosa” arquitetura moderna brasileira. No artigo "Bela Criança", que antecede 0 texto de Abelardo de Souza, já citado, Lina explora essa questão:

"Esta é uma tentativa para responder uma sentencia de Abelardo 'não sabemos ainda, precisar o porquê desse progresso da nossa arquitetura'. A arquitetura brasileira nasceu como uma bela criança, que não sabemos porque nasceu bonita, mas que devemos em seguida educá-la, curá-la, encaminhá-la, seguir sua evolução; houve o milagre do nascimento, a diretriz, a continuação da vida, o conseguimento de um intento coerente dependendo da consciência humana, de suas possibilidades para a luta, convicção, e intransigência. Isto é 0 que se deve afirmar". 24

Pode-se ler em "Bela criança" algo que Martins (1988) chama à atenção em Goodwin e que se tornaria recorrente na historiografia, uma trama marcada pela "indissociabilidade entre a "originalidade" e a projeção internacional da arquitetura brasileira e sua identificação a um projeto de articulação entre modernidade e tradição, sustentado e apoiado pela expansão e pelas necessidades de afirmação ideológica do aparelho estatal”25.

Neste mesmo sentido, Mindlin, anos depois do artigo de Lina para Habitat, em seu livro Modern Architecture in Brazil, irá falar sobre a espontaneidade e irracionalidade da arquitetura moderna brasileira, uma arquitetura de qualidade que cresce rapidamente em um meio hostil e pouco favorável, como conseqüência do processo cultural brasileiro que confirma seu caráter a-histórico.

"The story of modern architecture in Brazil is the story of a handful of young men and of body of work brought
into existence with incredible rapidity.
(...)
Its causes must therefore be sought in the intellectual and spiritual preparedness of the national frame of mind."
26 Apesar de apontar a importância da Semana de Arte Moderna, os manifestos de Warchavchik e de Rino Levi, o impacto dos projetos de Flávio de Carvalho e Warchavchik e a visita de Le Corbusier em 1929; Mindlin coloca estes como movimentos preparatórios do que viria com a "revolução" varguista, a qual efetivamente

\footnotetext{
${ }^{23}$ Apesar de nas publicações de número 10, 11, 12 e 13 aparecer o nome de Flávio Motta como diretor da revista, é mantida a mesma linha editorial. Esse fato é explicitado pelo próprio Flávio Motta em conversa com esta autora (2006), quando esclarece quais foram os motivos que o levaram a assumir a direção de Habitat, conforme apontado no Capítulo 1 deste trabalho.

${ }^{24}$ BO, Lina, "Bela Criança", Habitat, São Paulo, 1951, n. ${ }^{0}$ 2, p. 3.

${ }^{25}$ MARTINS (1988), op.cit., p. 16.

${ }^{26}$ MINDLIN, Henrique. Modern Architecture in Brazil, 1956. p. 1.

${ }^{27}$ Com relação às atividades promovidas pelo MASP: cursos ministrados por Pier Luigi Nervi (1950 e 1951), conferências de Henrique Mindlin (1948), Oscar Niemeyer (1948 e 1949) e Rino Levi (1949). Entre as exposições temáticas, a mostra
} 

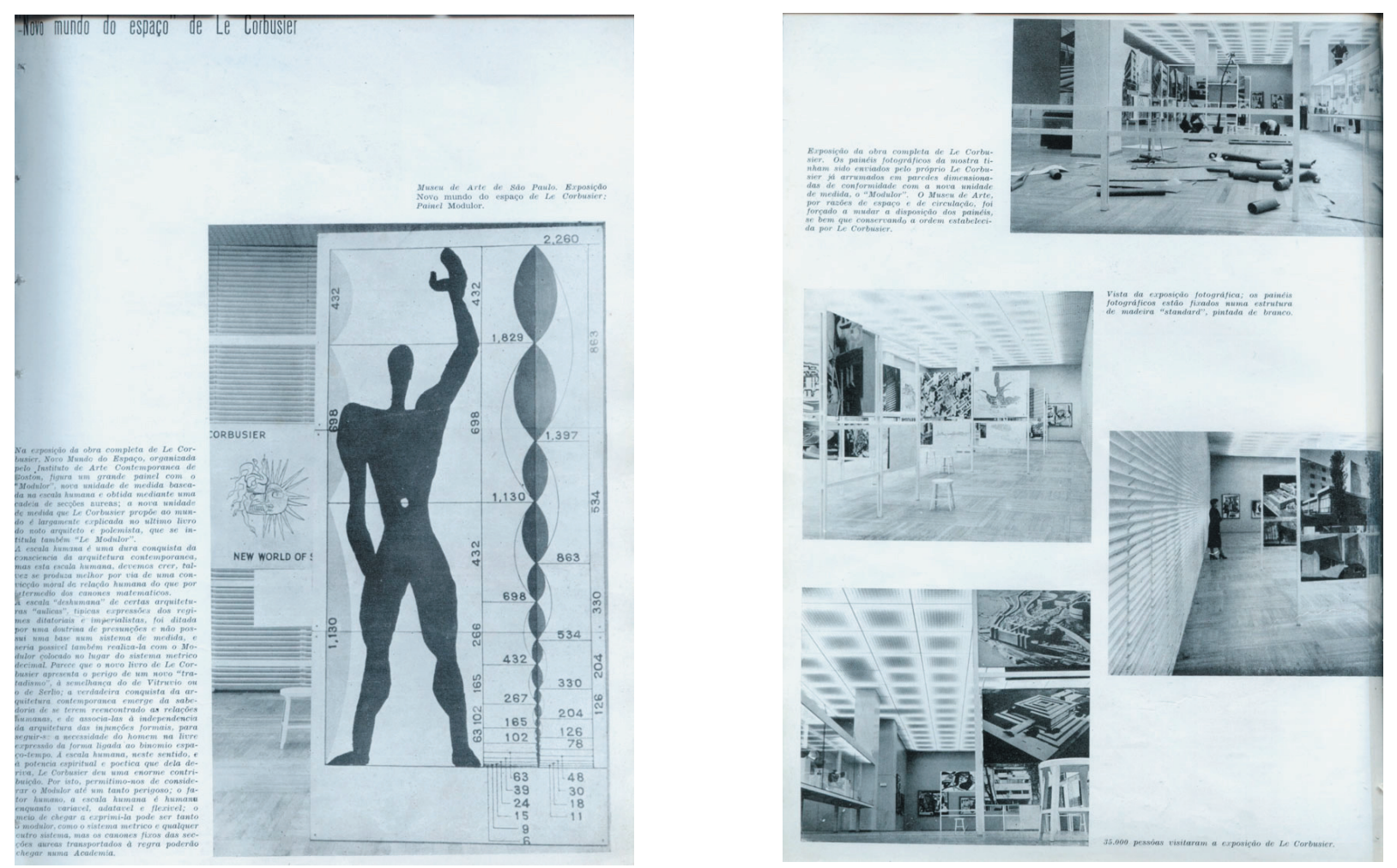

58 e 59 . A ampla divulgação em Habitat da exposição de Le Corbusier, realizada pelo MASP, colabora para a propagação dos ideais do arquiteto e aponta o risco do novo livro do arquiteto transformar-se em um novo "tratadismo".

autorizou a produção da arquitetura moderna pelo tom progressista, e propiciou com a vinda de Le Corbusier o desenvolvimento do edifício sede do Ministério da Educação e Saúde, e o desenvolvimento do talento dos jovens arquitetos brasileiros.

Goodwin já fala em 1943 das características extensivas que particularizam a arquitetura produzida aqui como brasileira, uma assimilação generalizada de normas e procedimentos lingüísticos e técnicos que reforça sua identificação por características formais.

0 enaltecimento de suas qualidades plásticas e construtivas, o resgate do passado, a construção de um léxico próprio, a disseminação do pensamento racional e das inúmeras realizações dessa arquitetura em São Paulo, tem espaço garantido em Habitat, ao lado do que torna público os valiosos esforços do nascente Museu de Arte de São Paulo27, organizador de mostras individuais, conferências, exposições temáticas e promoções de Planos de Londres e a $1^{\text {a }}$ Exposição Internacional de Arquitetura Contemporânea (1948); a Exposição Arquitetura Hospitalar (1949). Entre as mostras individuais, Lúcio Costa (1947), Flávio de Carvalho (1948 e 1949) e as internacionais: Le Corbusier e Richard Neutra (1950) e Max Bill (1951). Informações obtidas na publicação História do Masp, de Pietro Maria Bardi.

${ }^{28}$ Texto de Lina Bo datado de 7 de julho de 1978, encontrado no acervo histórico do Instituto Lina Bo e Pietro Maria Bardi. Documento transcrito na íntegra ver ANEXO 06. 
curso sobre arquitetura; que transformam essa publicação em veículo de consagração da arquitetura moderna brasileira, "documentada" num período posterior em suas páginas.

A publicação em Habitat de arquitetura ao lado de outros temas confirma o "depoimento" de Lina, escrito em $1972^{28}$, e a posição de Habitat como uma revista de cultura brasileira. Como já apontado anteriormente, as páginas da revista inserem a arquitetura no campo da cultura, ao lado de outras manifestações artísticas, como 0 artesanato, a fotografia, as artes gráficas, o desenho industrial, a pintura, o cinema, o teatro e a dança, entre outros. Diferente de apenas publicar a produção de arquitetura no Brasil há em Habitat o compromisso de divulgar e caracterizar uma produção inserida em um projeto de modernidade no campo da arquitetura e da cultura localizada na dinâmica da cidade de São Paulo nos anos 50. 0 que atribui à arquitetura publicada compartilhar o desejo de rompimento que a revista manifesta em suas páginas.

Ao publicar a arquitetura comprometida com uma ação social revolucionária, Habitat procura influenciar 0 campo profissional, convocando outros arquitetos para se alinhar a mesma causa. É o que podemos ver quando a revista anuncia um número especial, a edição de número 4 (jullho/setembro 1951), dedicada à produção do "Convênio Escolar":

\begin{abstract}
"Não é fácil encontrar material para a nossa seção de arquitetura. No Brasil, onde se constrói com ritmo excepcional e nas próprias grandes cidades como Rio e São Paulo, a arquitetura surge como um sentido genérico, próprio duma época que parece não ter tempo para refletir sobre fatos mais importantes do que sua vida e cultura.(...)

Estamos falando, pois nas dificuldades para encontrar material que testemunhe a nossa bela arquitetura, acertadamente considerada a melhor do mundo, ou pelo menos a que mais deseja e busca novas formas e pesquisas neste campo. No entanto, eis que de repente encontramos uma mina pouco vistosa, mas ótima para boas realizações e bons desenhos: 0 Centro de estudos para as construções de edifícios escolares (...)." ${ }^{29}$
\end{abstract}

Com raras exceções, os projetos de arquitetura publicados em Habitat exemplificam a arquitetura que a revista valoriza, uma arquitetura na qual as questões ideológicas estão acima das plásticas.

Desta forma é apresentada a produção do “Convênio Escolar”, um acordo entre o governo municipal e o federal firmado em 1948, a fim de solucionar o problema do ensino. Sua realização foi além da construção de edifícios escolares, mas também equipamentos públicos que visavam dotar a cidade de esporte, cultura e lazer. Dessa maneira, aliadas às escolas foram construídos: recantos e parques infantis, bibliotecas para adultos e jovens,

29 "Habitat 4 dedicada às Escolas". Habitat, São Paulo, nº 3, abr./jun. 1951, p. 29. 
teatros infantis, dispensários médicos, escolas pré-primárias, vocacionais, profissionais, ginásios, escolas para deficientes e escolar rurais.

0 "número especial" do "Convênio" traz um longo artigo intitulado "As arquiteturas do Convênio Escolar", no qual são publicados 22 projetos que deveriam ser construídos em 5 anos. Antecede a divulgação dos projetos um artigo de Hélio Duarte que problematiza e expõe os parâmetros que os nortearam, como as zonas de funções pelas quais o programa se organiza e outros aspectos intimamente ligados ao método de ensino a que as escolas se destinariam. Nesse artigo 0 autor discorre sobre o processo e as dificuldades que 0 grupo envolvido encontrou e sugere, com base na tese de Anísio Teixeira, a utilização da infra-estrutura das novas Escolas como pólos de bairro.

"Porque não considerar em cada bairro - a escola, o grupo escolar, como fonte de energia educacional, como ponto de reunião social, como sede das sociedades de "amigos do bairro", como ponto focal de convergência dos interesses que mais de perto dizem com a vida laboriosa de suas populações?"

Sobre esse olhar é apresentada a produção do "Convênio" no artigo "Um presságio de progresso" 30 , em que 0 educador Anísio Teixeira ${ }^{31}$ aponta a nova arquitetura ali realizada como exceção diante do cenário de conflitos e contradições de um país que se coloca entre "um exasperado senso de segurança e um trágico horror ao risco, aliados à coragem puramente passiva de tudo suportar". Ressalta estar se referindo a "arquitetura" que fez o Ministério de Educação, uma arquitetura que demonstra a possibilidade da construção da desejada nacionalidade, mas que ao lado dela existem outras não dignas dos mesmos comentários.

Os edifícios escolares em construção em São Paulo, sob direção técnica de Hélio Duarte, são apresentados como exemplo de uma arquitetura à brasileira e como elementos fundamentais para reverter o processo educacional obsoleto que o país já apresentava naquele momento. Hélio chama a atenção para o risco da desproporção entre os ideais e as atitudes, como visto no Ministério da Educação: um belo edifício ocupado por burocratas e circundado por pedintes; mas afirma que a produção do "Convênio" seria a oportunidade para acreditar que "o gesto pode gerar sentimento" e a arquitetura moderna seria este gesto.

Tendo o programa como meta a construção desses equipamentos até 0 ano de 1954, para as comemorações do IV Centenário de São Paulo, vemos neste período uma intensa produção de qualidade que tornou possível aos arquitetos iniciar aqui a realização do projeto moderno de transformação social.

\footnotetext{
${ }^{30}$ TEIXEIRA, Anísio, “Um presságio de progresso”, Habitat, São Paulo, n 3, abr.jun. 1951.

${ }^{31}$ Anísio Teixeira já havia se destacado anteriormente em Salvador, na Secretaria de Educação.
} 


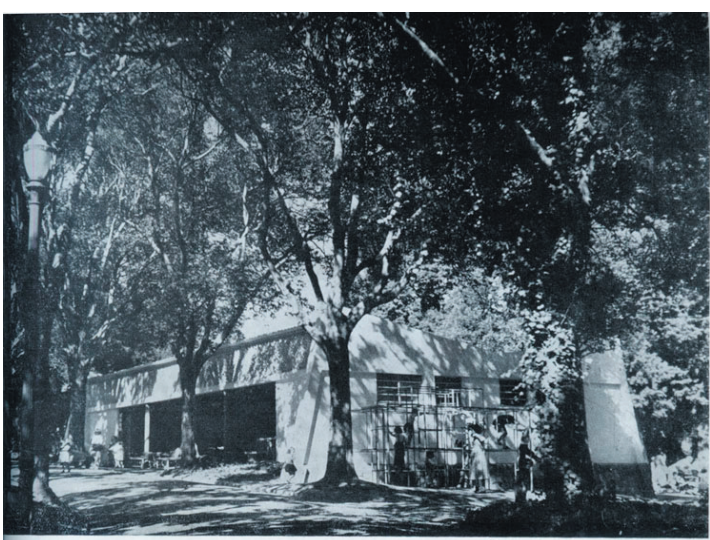

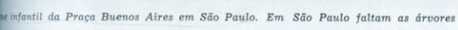

Soso Do convento escolar As arquiteturas do Convênio Escolar

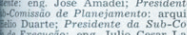

Di. arquititioses, arguitetos Eduardo
Rhberto Tibau, Oswaldo Goncal-

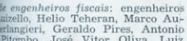

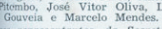

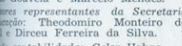
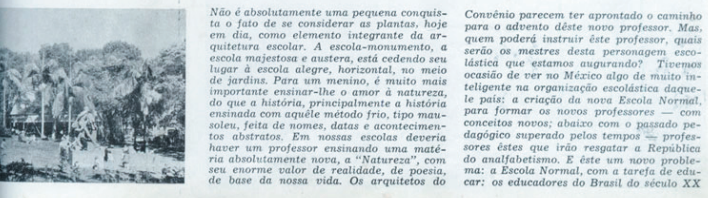

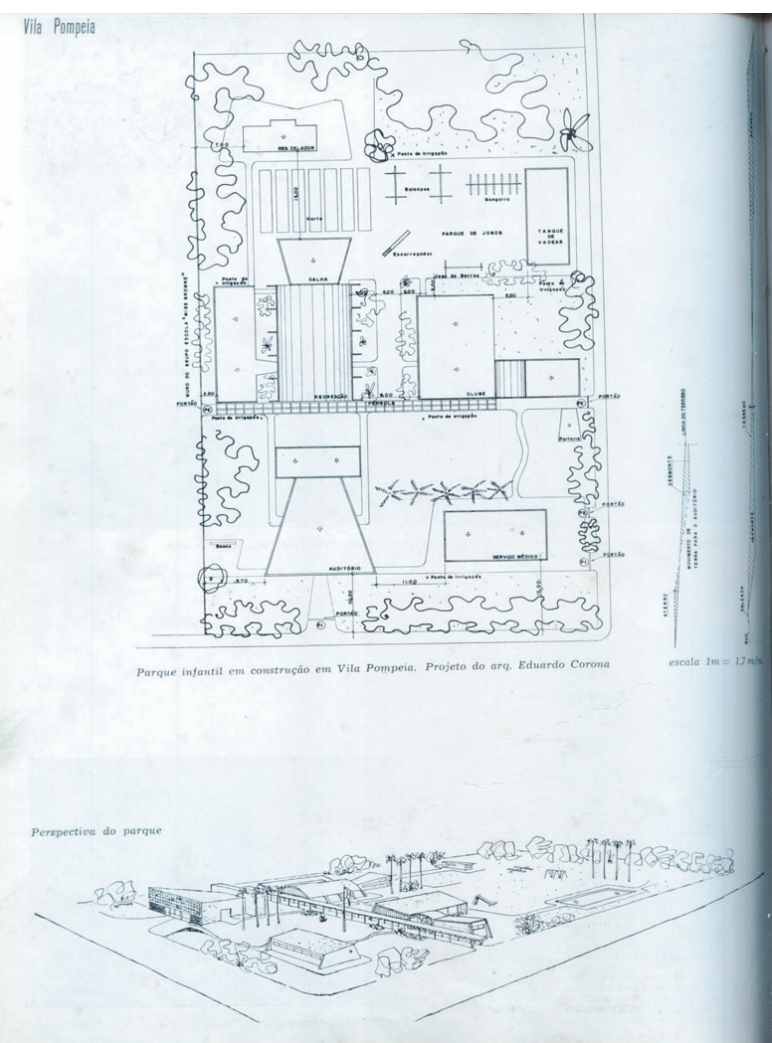

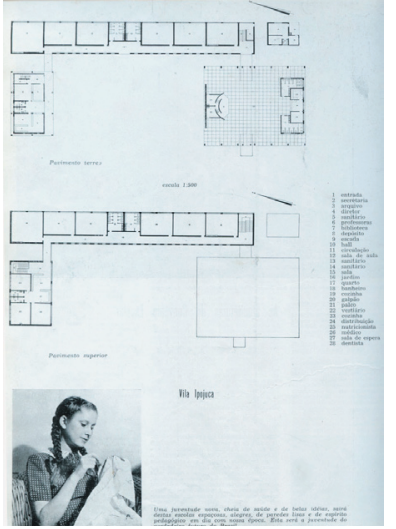

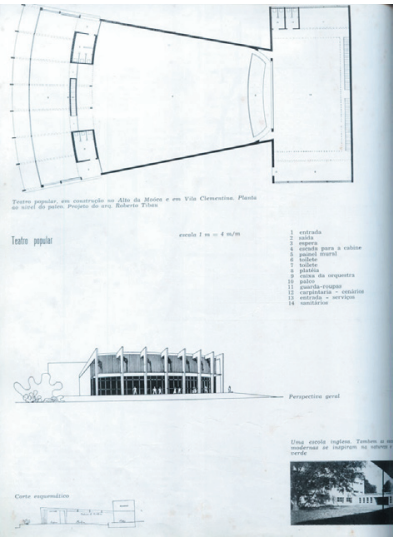

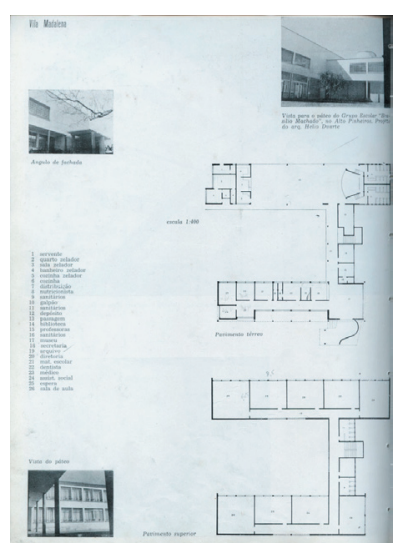

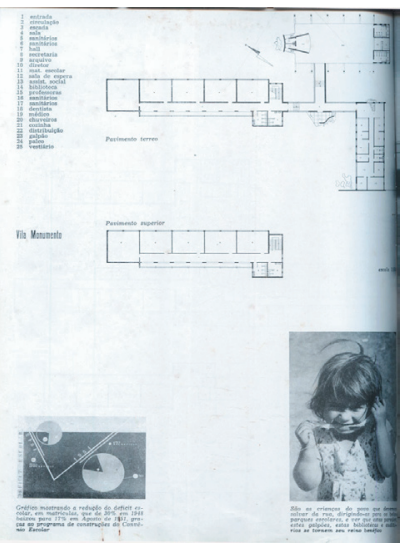

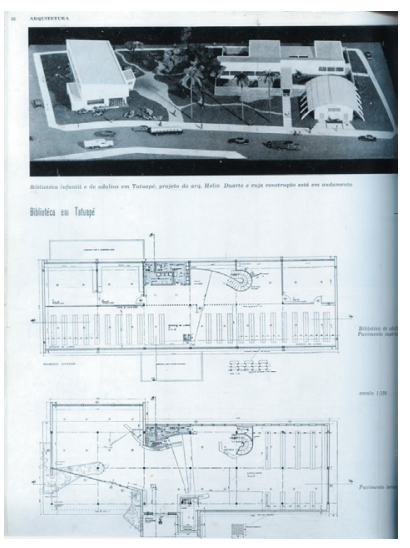

60 a 66 . Habitat dedica uma edição expecial, a de número 4 para divulgar a extensa produção de arquitetura do grupo do "Convênio Escolar". Como exemplar, são publicados projetos e obras concluidas de diversos equipamentos públicos, entre escolas, teatros, parques e creches. 
A produção do "Convênio Escolar", através do apoio estatal, destacou-se pela qualidade, contribuindo para a ampliação das oportunidades de realização e consolidação da arquitetura moderna em São Paulo. Seu grupo, formado pelos arquitetos Hélio Duarte, Eduardo Corona, Oswaldo Corrêa Gonçalves, Roberto Tibau e pelo engenheiro Roberto Mange, terá publicações, a partir de Habitat $n^{0} 4$, não apenas sobre a vasta produção de escolas realizadas para a Prefeitura Municipal de São Paulo, mas também sobre suas produções individuais, caracterizadas por projetos particulares, residências e edifícios de apartamento, todos afinados com a arquitetura moderna que a revista defende.

Ainda divulgando escolas, a revista $n^{\circ} 7$ (abril/junho 1952) publica mais dois projetos do programa do "Convênio" e a n 12, sobre três unidades do Senai, que neste momento conta com a colaboração de Roberto Tibau, Hélio Duarte e Roberto Mangue, e trabalham na qualificação da mão-de-obra para a indústria.

A arquitetura moderna que é publicada na revista se propõe a uma ação cultural, com os demais campos de linguagem também vinculados ao movimento modernista, pelos quais se acreditava ser possível uma intervenção no campo da cultura a fim de tirar a sociedade da incoerência que vinha caminhando.

“(...) 0 arquitetos modernos, os intransigentes, dizíamos, aqueles que trabalham em silencio e vêem na nova arquitetura 0 caminho à decência e à salvação para a humanidade, estes arquitetos pois, deveriam ser retratados como alguns santos antigos, de couraça e espada flamejante; a espada para combater a fasta multidão de incompetentes e ignorantes que avança com falsos cristais, falsos ouros, pernas retorcidas de cão ou leão, cortinas de cetim e de tafetá, franjas e adejos, mouros e mourinhos, estuques e estuquesinhos, armas e lustres de verdadeiros ou falsos Baccarat, com os acolchoados, os estofos, os matelassé, as porcelanas (especialmente as porcelanas), os cordões, a cor verde de amêndoa, cor de rosa de sorvete, branco de açúcar, azul, roxo, os ponpons, sobretudo os ponpons. (...) 0 público vê e muita vezes acredita, pela tendência própria do homem e seguir os baixos e em aparência estimulantes instintos, quando não há uma firme convicção profundamente enraizada para combate-los. Esta convicção nós a temos; somos sinceramente persuadidos pela cadeira de taboca ser mais moral e importante dum divã de franjas, de estilo 'frances'. (...)"32

Aqui também aparece a relação com o popular como fonte de inspiração e correção de princípios a serem adotados pela arquitetura contemporânea, em que a moral estaria vinculada à simplicidade e coerência dos objetos de uso cotidiano, pelos quais seria possível estabelecer um novo padrão de comportamento. É possível verificar em uma análise superficial dos demais números ${ }^{33}$ de Habitat a mudança de enfoque principalmente no que diz respeito à arquitetura. Se até aquele momento o principal foco de divulgação dos projetos era São Paulo e como exceção a "arquitetura popular" presente no interior do país, o número 16 publica três projetos internacionais - USA, Polônia e México -, fato que se repete a partir daí ao longo da

\footnotetext{
32 "Alencastro", Habitat, São Paulo, nº 2, 1951, p. 91.
} 
vida da revista. Vale apontar que nesta outra etapa de Habitat a arquitetura popular também perde seu lugar, inicialmente garantido pelo interesse de Lina Bo.

A arquitetura moderna brasileira já consagrada passa a ser publicada na segunda fase da revista (aqui identificada) em forma de importantes documentos, como as colunas de Geraldo Ferraz, "Individualidades na história da atual arquitetura no Brasil" ${ }^{34}$ e "Novos valores da arquitetura brasileira" 35 , que realizam criticamente o percurso profissional do arquiteto "eleito" e a "catalogação" de suas obras. Altera também o cenário da produção de arquitetura no Brasil as comemorações do IV Centenário de São Paulo e a realização do Parque do Ibirapuera e seu conjunto de edifícios, e, principalmente, a construção de Brasília.

Em Habitat a divulgação de arquitetura é dada por artigos de divulgação e artigos polêmicos. Os artigos de divulgação de arquitetura, de maneira geral, apresentam, debatem ou polemizam um ou mais projetos de arquitetura - como exemplo 0 artigo "As arquiteturas do Convênio Escolar", em Habitat $n^{0}$ 4, que traz mais de vinte projetos de escolas. Em sua maioria, os artigos de divulgação são constituídos de peças gráficas - desenhos, croquis e imagens da maquete ou obra construída - que constituem figuras-chave para a compreensão do objeto analisado e ainda um breve texto descritivo $0^{36}$, no qual 0 compromisso muitas vezes se limita a esclarecer o sistema construtivo, a materialidade do edifício e sua localização.

A autoria dos textos e notas que esclarecem e ilustram o projeto divulgado, muitas vezes é assinado pelo próprio autor do projeto publicado, o que dificultaria uma análise imparcial à obra, já que a crítica se faz a partir do distanciamento do objeto em análise, tarefa difícil para o autor. No entanto, é importante lembrar que esses projetos são "escolhas" da direção e fazem parte de um "projeto editorial” com um compromisso já aqui explicitado: publicar uma arquitetura artisticamente social.

\footnotetext{
${ }^{33}$ A partir do $n^{0} 16$ até a ultima publicação, a de $n^{0} 84$ (jul./dez. 1965).

${ }^{34}$ Individualidades na história da atual arquitetura no Brasil (I) Gregori Warchavchik, Habitat, São Paulo, n 28, p. 49; (II) Affonso Eduardo Reidy, Habitat, São Paulo, n 29, p. 38; (III) Rino Levi, Habitat, São Paulo, n 30, p. 34; (IV) M. M. M. Roberto, Habitat, São Paulo, no 31, p. 49; (V) Lúcio Costa, Habitat, São Paulo, nº 35, p. 28; (VI) Roberto Burle Marx, Habitat, São Paulo, n 36, p. 57.

35 "Novos valores da arquitetura brasileira" (I) Abelardo Reidy de Souza, Habitat, São Paulo, nº 39, p. 2; (II) Oswaldo Bratke, Habitat, São Paulo, nº 45, p. 21.

${ }^{36}$ Alguns artigos publicam material gráfico do projeto em foco, sem apresentar nenhum texto que localize ou esclareça 0 objeto, ficando esta tarefa totalmente a cargo do título do artigo e das pequenas notas que acompanham as imagens publicadas. Como exemplo 0 artigo publicado em Habitat, $\mathrm{n}{ }^{011}$ "Estádio em São Paulo", em que o projeto do arquiteto Vilanova Artigas é apresentado exclusivamente por imagens da maquete e desenhos realizados para o concurso vencedor.
} 
0 outro "tipo" de divulgação, os artigos polêmicos sobre arquitetura, não se dedica apenas a divulgar ou discutir um projeto de arquitetura ou obra específica, mas sim a desenvolver criticamente argumentos em torno de questões que permeiam a arquitetura eleita pela revista e o projeto cultural nela embutido.

Neste sentido, faz-se necessária a atenção para quem são os autores desses ensaios, que passam neste momento a exercer o papel de críticos de arquitetura em Habitat, contribuindo para a difusão do ideário moderno. Entre eles tem destaque Pietro Maria Bardi, Lina Bo, Flávio Motta e o arquiteto Abelardo de Souza, que além de colaborador da revista terá seus projetos amplamente divulgados em suas páginas, como veremos adiante.

As imagens que acompanham esses artigos, em sua maioria fotografias, completam o sentido do texto e acentuam seu caráter crítico, principalmente nos dedicados às questões urbanísticas ou à arquitetura popular.

É possível destacar em ambas as formas de abordagem alguns "grandes temas" recorrentes, como o resgate e 0 elogio à dita arquitetura popular, a divulgação e a crítica à arquitetura moderna brasileira, e questões em torno do urbanismo e do crescimento das cidades.

Dentre os artigos relativos à arquitetura, elegemos e reunimos para análise os que afirmam o projeto e 0 compromisso de Habitat:

"(...) dedicaremos pois ensaios à história da arte brasileira afim de fundir os tempos numa só época, sem a balisa das classificações, dividindo 0 antigo do assim chamado moderno - adjetivo que entrou infelizmente em voga. A beleza imaginativa de uma floresta, de uma cabana de pau-a-pique, de um pote marajoara, de uma igreja barroca, o Aleijadinho, os ourives da Bahia, os moveleiros manuelinos de Recife, os epígonos da missão francesa, os arquitetos do teatro de Manaus e os do Ministério da Educação e Saúde do Rio (...)". ${ }^{37}$

Compromisso que procuramos afirmar, com o da defesa de uma arquitetura artisticamente social. Ao eleger este recorte, ficaram de fora deste trabalho muitos outros artigos, não menos importantes, mas que sugerem outros aspectos que o presente estudo não se propõe a realizar.

37 "Prefácio", Habitat, São Paulo, nº 1, 1950, p. 1. 


\subsection{Habitat e a arquitetura popular}

“0 povo nasce realmente com a arquitetura no sangue. Não é uma simples afirmação retórica, mas o instinto construtivo e instinto inato" ${ }^{38}$

Logo na primeira edição de Habitat (1950), o artigo "Amazonas: o povo arquiteto" discorre sobre 0 tema da arquitetura popular, marcada pela sabedoria da simplicidade, da racionalidade e da "construtura lógica" presentes em suas construções. Esse enfoque - sabedoria popular - estará presente em diversos artigos, não apenas relacionados à arquitetura, mas também às artes e ao artesanato. Os quais têm como argumento os valores da sociedade brasileira: "o milagre de uma sociedade que fala uma só língua há séculos, que se criou numa amalgama de elementos históricos provindos de continentes tão diversos" 39 , e reproduzem imagens do hábitat dessa "gente" chamando a atenção para "uma arquitetura funcional e muito estética".

A sabedoria popular e a riqueza de sua produção são mostradas em Habitat também nos artigos que destacam a utilização de materiais locais, principalmente aplicados à produção industrial, como a juta, o sisal e o algodão, cuja beleza e adaptação ao clima os fazem exemplar:

"Esta fibra vegetal, tipicamente brasileira se presta a aplicações das mais surpreendentes e expressivas. Num país tropical, os materiais secos e a fibra resistente, como esta, oferecem inúmeras possibilidades. Nada mais fora de lugar do que um 'atapetado' de lã num clima de prevalência quente e úmido, isto combina com as cortinas de falso cetim que se arrastam pelo chão. (...)" ${ }^{\prime 40}$

A mesma valorização do popular figura nos artigos que apresentam a produção do desenho industrial contemporâneo, que podem ser vistos na produção de cadeiras do Studio de Arte Palma. Sobre este mobiliário, a revista destaca não apenas a utilização das madeiras brasileiras, mas aspectos de seu desenho que absorvem a sabedoria popular, como as redes ${ }^{41}$ utilizadas no Norte e Nordeste do país:

38 "Belém", Habitat, São Paulo, nº 7, out./dez. 1952, p. 47.

${ }^{39}$ Bo, Lina. "Amazonas: o povo arquiteto", Habitat, São Paulo, no 1, São Paulo, 1950, p. 68.

40 "0 Sizal”, Habitat, São Paulo, nº 1, São Paulo, 1950, p. 63.

${ }^{41}$ A rede também aparece valorizada no Pavilhão do Brasil na XIII Trienal de Milão, em 1964, assinado por Lucio Costa. Com a rede 0 arquiteto procura responder ao tema proposto pela Trienal: o tempo livre; unindo a valorização das tradições culturais brasileiras com possibilidades espaciais modernas. COSTA, Lucio. "Tempo livre. Pavilhão do Brasil: Riposatevi". In: COSTA, Lucio, Registros de uma vivência, São Paulo: Empresa das Artes, 1995, p. 408-409. 

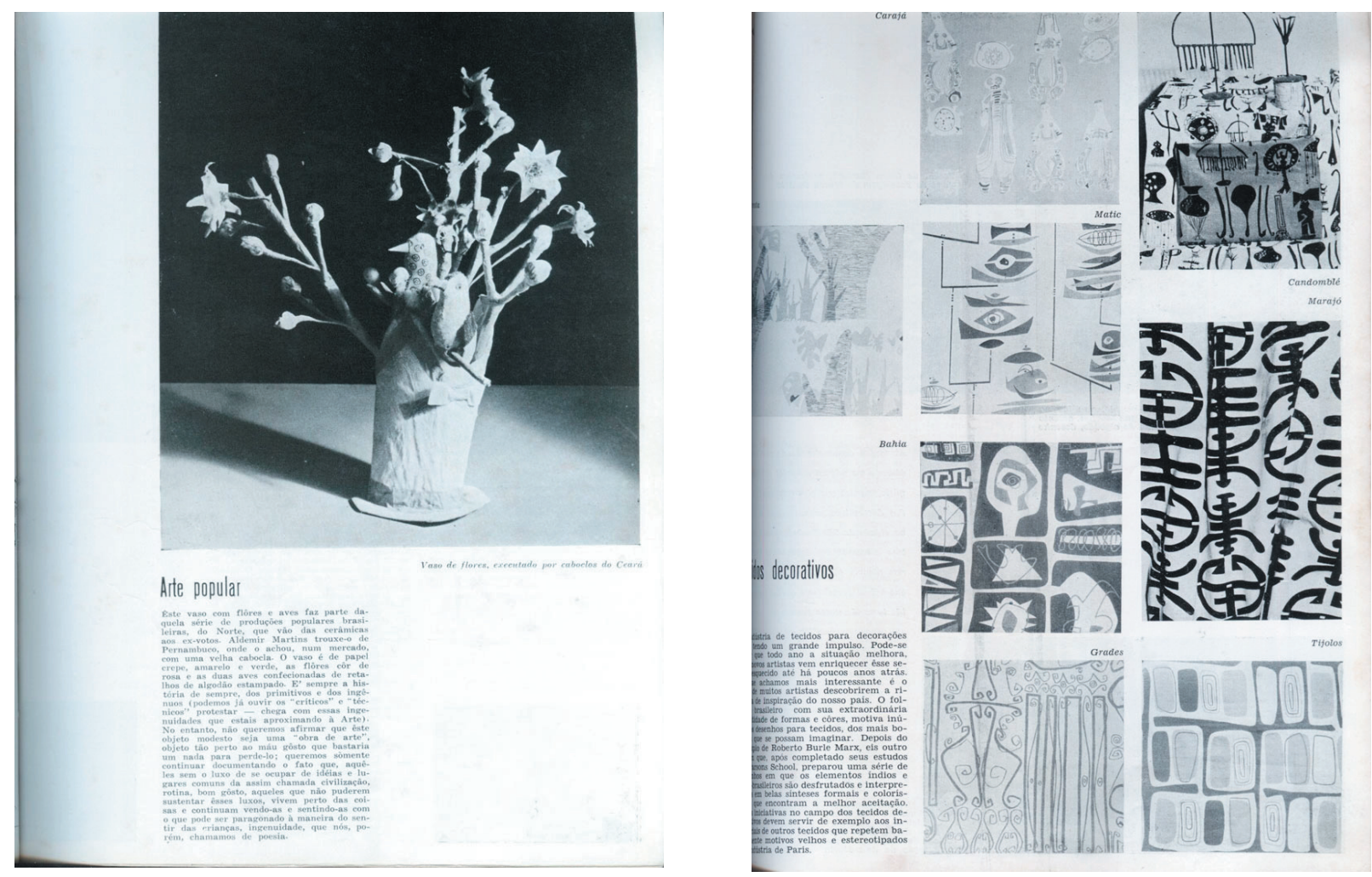

67 e 68 . A valorização do popular e do não erudito é apresentado por Habitat como uma via para o desenvolvimento de uma produção com características particulares, através da qual seria possível a conquista da desejada identidade.

"Nos navios 'gaiolas' que navegam os rios do norte do país a rede é, como em todo o resto do país, a um só tempo leito e poltrona. A aderência perfeita à forma do corpo, o movimento ondulante, fazem dela um dos mais perfeitos instrumentos de repouso. As poltronas que ilustram estas páginas nascem das redes. Diferem da conhecida 'tripolina' de couro, igualmente inspirada no princípio do 'forro solto', pelo movimento ondulante que 0 corpo pode imprimir ao forro." ${ }^{42}$

Ainda na primeira publicação da revista, antecedendo o primeiro artigo sobre arquitetura popular, figura duas páginas dedicadas à arte indígena, com título que induz à leitura: "0 índio desenhista" e "0 índio modista". Respectivamente são apresentadas seqüências de imagens em que 0 autor aponta a riqueza presente nas peças apresentadas - grafismos e cocares - e sua contemporaneidade:

"(...) Um refinado pintor contemporâneo não iria mais longe."43

"(...) Uma refinadíssima modista européia não poderia criar uma elegância maior”. ${ }^{4}$

Na página seguinte, com "Amazonas: o povo arquiteto", Habitat completa a idéia desta sabedoria popular. As imagens publicadas não são de uma oca indígena, mas poderiam ser. 0 texto discorre sobre a habilidade nata

${ }^{42}$ Texto que acompanha uma fotografia do interior de um navio 'gaiola' povoado de redes. "Móveis novos", Habitat, São Paulo, $n^{0} 1,1950$, p. 54.

43 "0 índio desenhista", Habitat, São Paulo, nº 1, 1950, p. 66.

44 "0 índio modista", Habitat, São Paulo, nº 1, 1950, p. 67. 
presente nessa gente que sabe fazer o que precisa para viver dignamente, entre comentários que apontam 0 inverso nas grandes cidades, realizando de forma velada a crítica ao urbanismo e sua regulamentação:

"Para o povo arquiteto do Amazonas, construir uma moradia não é problema tão difícil como para o morador da cidade, é um ato normal, fácil, natural, que toda a família pode resolver por si, sem a intervenção daquele mundo de fiscais que se abate sobre uma construção como moscas mutucas.

E nem a urbanística é um problema na Amazonas: a boa gente de lá possue (sic) espaçosas avenidas fluviais, ladeadas por arvores e sempre limpas em seu fundo". ${ }^{45}$

Daí as imagens que ilustram o artigo: moradas simples do povo no interior do país onde o que importa é a função e a estética; imagens que revelam a importância de considerar o que há de verdadeiro na cultura do povo. Figuram entre elas não apenas construções, mas o modo de vida desse povo do Amazonas: 0 "casamento em série" em uma comunidade de seringueiros localizada no Alto Purus; um cortejo fúnebre no Pará; uma festa de samba, no Rio Guaporé; e um comboio no Rio Amazonas. Todas essas imagens procuram retratar a simplicidade dos costumes desse homem brasileiro que sabe como deve viver!

Mas não apenas o povo que habita o Norte do país é apresentado em sua sabedoria. Também o migrante e 0 camponês que ocupam a periferia das cidades ganham destaque em artigos movidos pelo mesmo argumento em "Por que o povo é arquiteto?" e "Casa de 7 mil cruzeiros". Neles o retrato das soluções criativas, movidas pela necessidade, ganha destaque. Ao documentar a residência de uma família de Em’boy (periferia de São Paulo) que vive do trabalho em uma olaria, Habitat constata que por necessidade o povo pode ser ao mesmo tempo: arquiteto, proprietário, jardineiro, pintor, e quantas outras coisas precisem para realizar uma bela casa $^{46}$.

"A senhora de Em'boy construiu sua casa com sete mil cruzeiros. É toda em tijolos, que ela mesma fabricou, deixados a vista, as janelas foram escolhidas de uma obra em demolição, as telhas foram compradas a prestação, assim como o pequeno terreno cercado por um canavial. Para o interno, cujas paredes são também de tijolos a vista, essa senhora fez móveis de madeira tosca, usando tábuas de caixotes: uma maravilha de proporções, e o gosto natural de gente do campo fortemente contribuiu para aconselhar beleza, racionalidade e inteligência. (...)

Eis a casa de sete mil cruzeiros; e eis um abraço em nome das pessoas que acreditam na humanidade dessa mulher do povo, um das tantas anônimas que colocamos ao lugar de honra, como uma simpaticíssima dama." 47

Com esses artigos Habitat coloca ao lado da arquitetura moderna, a arquitetura popular encontrada no interior

\footnotetext{
45 "Amazonas: o povo arquiteto", (1950), op cit.

${ }^{46}$ Artigo atribuído a Lina Bo. "Casa de 7 mil cruzeiros”, Habitat, São Paulo, nº 3, abr.-jul., 1951, p.4.

47 "Casa de 7 mil cruzeiros" (1951), op. cit.
} 


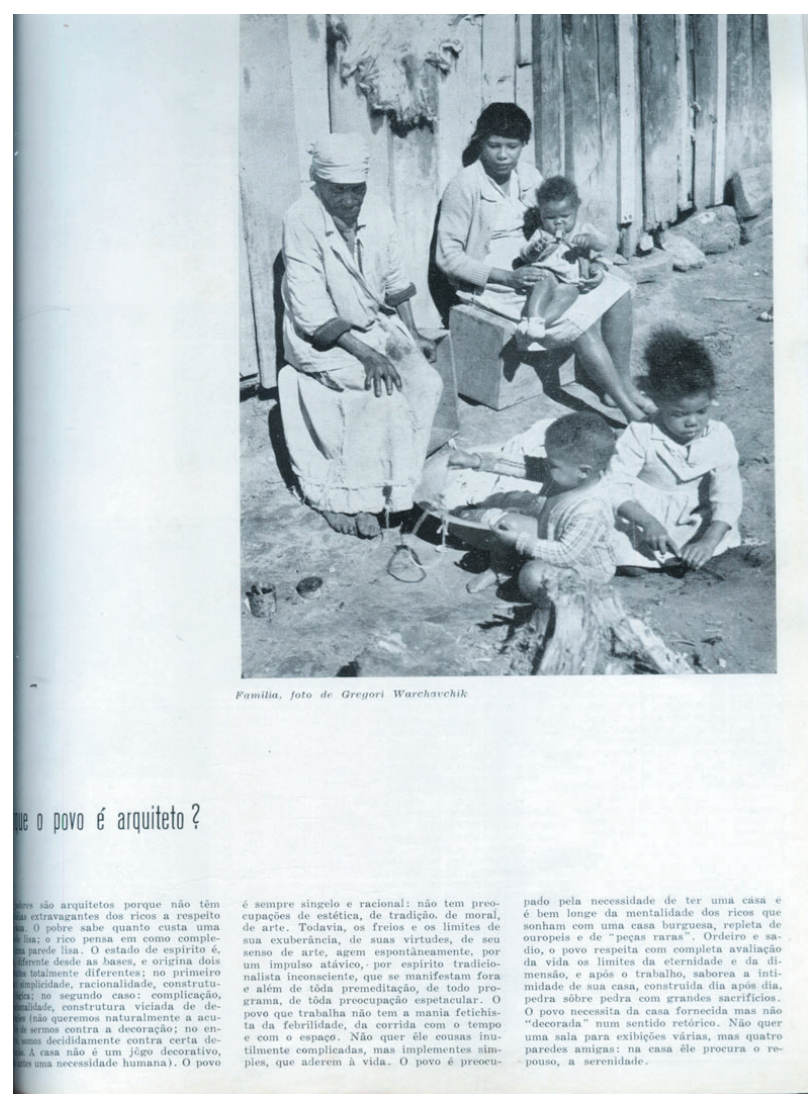

69 e 70 . "Por que o povo é arquiteto?" e "Casa de 7 mil cruzeiros", respectivamente, são exemplos de artigos de autoria de Lina Bo, publicados em Habitat e que iniciam no Brasil um trabalho pela valorização da cultura popular e pela "moralidade" na arquitetura. A "honestidade" e a "coerência" das construções realizadas no interior do país são divulgadas como exemplo de ação aos arquitetos e à sociedade burguesa.

"A senhora de Em'boy construiu sua casa com sete mil cruzeiros. É toda em tijolo que ela mesma fabricou, deixados a vista (...). Para 0 interno cujas paredes são também de tijolos a vista, essa senhora fez móveis de madeira tosca, usando tábuas de caixote: uma maravilha de proporção, e o gosto natural de gente do campo fortemente contribuiu para aconselhar beleza, racionalidade e inteligência.

B0, Lina. "Casa de 7 mil cruzeiros", Habitat n ${ }^{0} 3$, abr. / jun. 1951, p. 4.

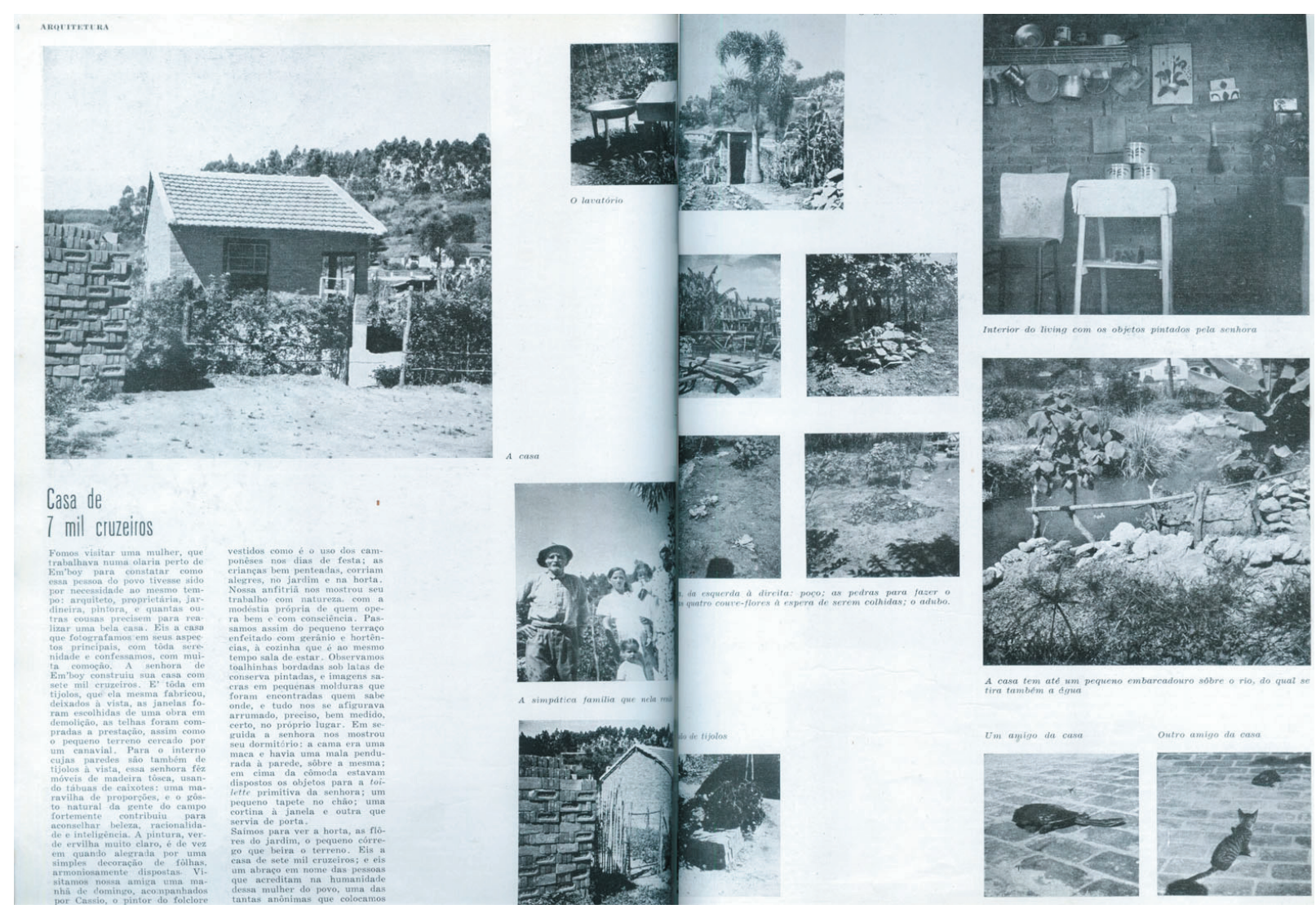


do país e nas periferias das cidades. Realizada pelo "povo arquiteto", a arquitetura de palafitas e pau-a-pique é apresentada nas páginas da revista não em caráter folclórico, mas como a necessidade de considerarmos 0 nosso passado, o erudito e o popular, e, a partir dele, redefinir o presente introduzindo algo que mais tarde Lina chamará de alma brasileira. A partir do reconhecimento do passado e dos valores da nossa cultura popular a possibilidade de construir uma modernidade com características próprias, com a expressão cultural do povo brasileiro.

“(...) As heranças são pesadas, e as 'não-heranças' são perigosas e dificilmente superáveis por falta de exemplos que, apesar de tudo, criam uma 'a atmosfera' da cultura (...)

Não somos fautores de casa de 'pau a pique' nem tampouco da cultura anteposta ao fato criativo arquitetônico: o que reputamos necessário, hoje em dia, é um justo meio, e pois nem o 'dogmatismo' nem o 'impressionismo', mas uma espécie de medida, naturalmente crítica que, levando em consideração a história como herança e continuidade, abra as mais amplas liberdades às possibilidades do arquiteto, hoje mais do que nunca mediador responsável pelo 'modo de viver' dos homens." 48

Flávio Motta chama a atenção para o olhar de Lina, recém-chegada ao Brasil, "para essa gente" ${ }^{49}$. E é esse olhar de descoberta e interesse que empresta aos artigos publicados em Habitat, os quais embora sem assinatura the são atribuídos pelo conteúdo que apresentam na defesa do reconhecimento dos valores da cultura popular, que será a base da ação de Lina no Nordeste do Brasil entre os anos de 1958 e 196450, pelo italianismo presente nos textos e pela confirmação dada por Motta à Campello51.

0 interesse pelos valores presentes na produção popular explicitados em Habitat pode ser visto como resultado do ambiente profissional de Lina na Itália ${ }^{52}$. 0 trabalho no escritório do arquiteto Giò Ponti, "líder do movimento pela valorização do artesanato italiano, diretor das Trienais de Milão e da revista Domus"53, e da revista Lo

${ }^{48}$ BO, Lina, Contribuição propedêutica ao ensino de teoria da arquitetura, São Paulo: Instituto Lina Bo e P. M. Bardi, 1957, p. 50-1.

${ }^{49}$ Depoimento dado a esta autora em maio de 2006, não gravado por pedido do professor Flávio Mota. Nele Motta cantarola a canção popular Gente Humilde (de Garoto, Vinicius de Moraes e Chico Buarque,1969), pela qual explicita de que "gente" estava falando.

${ }^{50}$ Sobre 0 trabalho desempenhado por Lina no Nordeste, ver PEREIRA, J. A., A ação cultural de Lina Bo Bardi na Bahia e no Nordeste (1958-1964). São Carlos, 2001. Dissertação (Mestrado) - Departamento de Arquitetura e Planejamento, Escola de Engenharia de São Carlos, Universidade de São Paulo.

${ }^{51}$ Motta atribui a autoria de Lina em todos os textos referentes a arquitetura popular. Ver CAMPELLO, Maria de Fátima M. B., Lina Bo Bardi: as moradas da alma. São Carlos, 1997. Dissertação (Mestrado) - Departamento de Arquitetura e Planejamento, Escola de Engenharia de São Carlos, Universidade de São Paulo.

${ }^{52}$ Neste momento, na Itália, o resgate da história se faz por uma apropriação do passado a partir das necessidades do presente. Necessidades que apontem duas preocupações: a construção de uma identidade nacional (unificada tardiamente, a Itália mais que os outros países tinham uma preocupação em caracterizar uma proposta de modernidade permeada pelas tradições locais. Nesse sentido, as principais revistas de arquitetura da época - Architettura i Arti Decorative, Casabella, Domus e Quadrante - assumem esse debate) e a reconstrução no pós-guerra através da desmistificação da máquina.

${ }^{53}$ BARDI, in FERRAZ (1993). 
Stile ${ }^{54}$, nas quais Lina passa a publicar alguns ensaios ${ }^{55}$; deixa evidente seu interesse por essa arquitetura anônima, resultado da soma de conhecimentos milenares.

A aproximação entre o passado e o presente, o tradicional e o moderno que irá caracterizar os artigos de Lina em Habitat sobre arquitetura popular, já está presente, por exemplo, em um ensaio de sua autoria para a revista Domus, em 1943.

“(...) L'indagine realística del mondo moderno, distruttice di ogni superficialità, di ogni preconcetto, di ogni decorativismo, há riportato l'architettura al rapporto SUOLO CLIMA AMBIENTE VITA, rapporto che, com meraviglioso primitivismo vediamo scaturire dalla più spontanea delle forme d'architettura: l'architettura rurale. Della corripondenza perfetta di questa architettura com l'ambiente nel quale la vita dell'uomo si sviluppa, abbiamo in tutto il mondo esempi, primo fra tutti quello della casa mediterranea, pura, perfettamente aderente al suolo e al paesaggio, coerente alla vita che vi si svolge.

(...) L'istinto primordiale del riparo che ispirò le capanne di paglia e rami, i rifugi a cono, a cubo in massicci blocchi di pietra si ritrova oggi, attraverso una evoluzione profunda, nelle architetture di case che, se pur rispondenti alle severe leggi di funzionalità ed essenzialità dell'architettura moderna, conservano sempre la 'purezza' delle forme spontanee e primordiali dalle quali derivano: quel conservare ancora nella pietra regolarizzata, nel legno lavorato quel senso di 'puro' di 'naturale' che le fa attaccate, radicate alla terra dove sono nate, fuse com la natura, immerse in quel paesaggio". ${ }^{56}$

Campello aponta a proximidade do discurso da genealogia entre a cabana primitiva e a arquitetura moderna de Lina e os caminhos de Giuseppe Pagano na Itália, responsável, com Guarniero Daniel, pela organização da IV Triennale di Architettura Rurale (1936), considerada por alguns críticos como o ponto culminante da experiência racionalista italiana, na qual a arquitetura "espontânea" aparece com a mostra de arquitetura rural: uma dedicada a casa e ao mobiliário e outra sobre o urbanismo e os planos reguladores. ${ }^{57}$ Giuseppe Pagano neste momento desenvolve um trabalho de crítica e divulgação da arquitetura racionalista na Itália, com Edoardo Persico, na direção da revista Casabella, na qual publica seus primeiros trabalhos resultado de suas reflexões sobre 0 tema architettura rurale, no qual qualifica não as formas singulares, mas 0 instinto que as construiu.

0 interesse de Pagano pela chamada arquitetura espontânea contém diversos fatores de sua obra crítica e polêmica. Nessas construções ele aponta a existência do "orgulho na modéstia" de que falava Venturi em relação à arquitetura racional. A partir dela estabelece uma analogia entre a construção rural e a arquitetura

\footnotetext{
${ }^{54}$ Sobre os fatores que levaram a saída de Ponti da Domus para a Lo Stile, ver TENTORI, F., PM Bardi: com as crônicas artísticas do "L'Ambrosiano" 1930-1933. Trad. de Eugênia Gorini Esmeraldo, São Paulo: Instituto Lina Bo e P. M. Bardi/ Imprensa Oficial do Estado, 2000, p.160.

${ }^{55}$ Em "Tende e cabine", Lo Stile, $n^{0} 7,1941$, p. 40-1; os autores Lina Bo e Carlo Pagani projetam abrigos desmontáveis para a praia, a partir da observação da paisagem natural e da paisagem construída da costa mediterrânea.

${ }^{56}$ BARDI, Lina Bo "Architettura e natura - la casa nel paesaggio", Domus, nº. 191, nov. 1943, p. 464.

${ }^{57}$ CAMPELLO (1997), op. cit.
} 
moderna devido ao caráter abstrato-geométrico desta, entendido num sentido não formalista, contrapondo essa tradição popular-nacional à retórica da tradição palaciana ${ }^{58}$.

Em 1944, ao assumir a direção da revista Domus juntamente com Carlo Pagani, Lina Bo publica extenso material sobre a genealogia da casa moderna. No segundo número, sob direção da dupla, um artigo ${ }^{59}$ aponta a origem espontânea da solução em pilotis utilizada em casa de pescador, toda construída em madeira; idéia que aparece também na construção medieval, que, sob os arcos, abriga no térreo espaços públicos.

Este artigo, publicado na Itália em 1944, assemelha-se pela temática aos artigos publicados em Habitat, em especial o já comentado e presente em seu primeiro número (1950), "Amazonas: o povo arquiteto", que reproduz cenas do hábitat de gente do Amazonas e chama a atenção para "uma arquitetura funcional e muito estética". Também no terceiro número da revista (1951), com o mesmo argumento “Porque o povo é arquiteto?" traz a demonstração da sabedoria do povo, presente na simplicidade, na racionalidade e na "construtura lógica" de suas obras:

"Os pobres são arquitetos porque não tem as idéias extravagantes dos ricos a respeito da casa. 0 pobre sabe quanto custa uma parede lisa; o rico pensa em como completar esta parede lisa. 0 estado de espírito é, pois, diferente desde as bases, e origina dois produtos totalmente diferentes; no primeiro caso: simplicidade, racionalidade, construtura lógica; no segundo caso: complicação, irracionalidade, construtura viciada de decorações (...) 0 povo é sempre singelo e racional: não tem preocupações de estética, de tradição, de moral, de arte. Todavia, os freios e os limites de sua exuberância, de suas virtudes, de seu senso de arte, agem espontaneamente, por um impulso atávico, por espírito tradicionalista inconsciente, que se manifesta fora e além de toda premeditação, de todo programa, de toda preocupação espetacular. 0 povo que trabalha não tem a mania fetichista da febrilidade, da corrida com o tempo e com o espaço. Não quer ele cousas inutilmente complicadas, mas simplesmente simples, que aderem a vida. (...)" ${ }^{60}$

A aproximação entre a arquitetura moderna e o primeiro abrigo do homem está presente também no discurso de Le Corbusier, em sua vinda a Buenos Aires em 1929.

"He dibujado la cabãna del salvaje, el templo primitivo, la casa del campesino y he dicho: estos organismos creados com la autencidad que la misma naturaleza, pone en sus obras - su economía, su pureza, su intensidad - son ellos que, un dia de sol y de clarividencia, se han convertido en palacios. He ensenãdo la casa del

\footnotetext{
${ }^{58}$ DE FUSCO, Renato, La ideia de arquitectura: história de la critica desde Viollet Le Duc a Persico. Barcelona: Gustavo Gili, 1976, p. 255.

59 “Case sui trampoli”,Domus, Milão, n 195, mar. 1944a, p. 86-7. Observe-se, portanto, que a temática da arquitetura popular foi uma constante no período de formação de Lina na Itália. Cesare de Seta na introdução ao livro de Pagano. Architettura e città durante il fascismo. Bari: Laterza, 1990, afirma que 0 tema da arquitetura rural estará presente nas páginas da revista Casabella no período de 1931 a 1943.

${ }^{60} 0$ artigo "Por que o povo é arquiteto?", Habitat, nº 3, São Paulo, abr.-jul. 1951, p. 3, como todos os demais que tem como argumento a arquitetura popular, é atribuído a Lina Bo.
} 


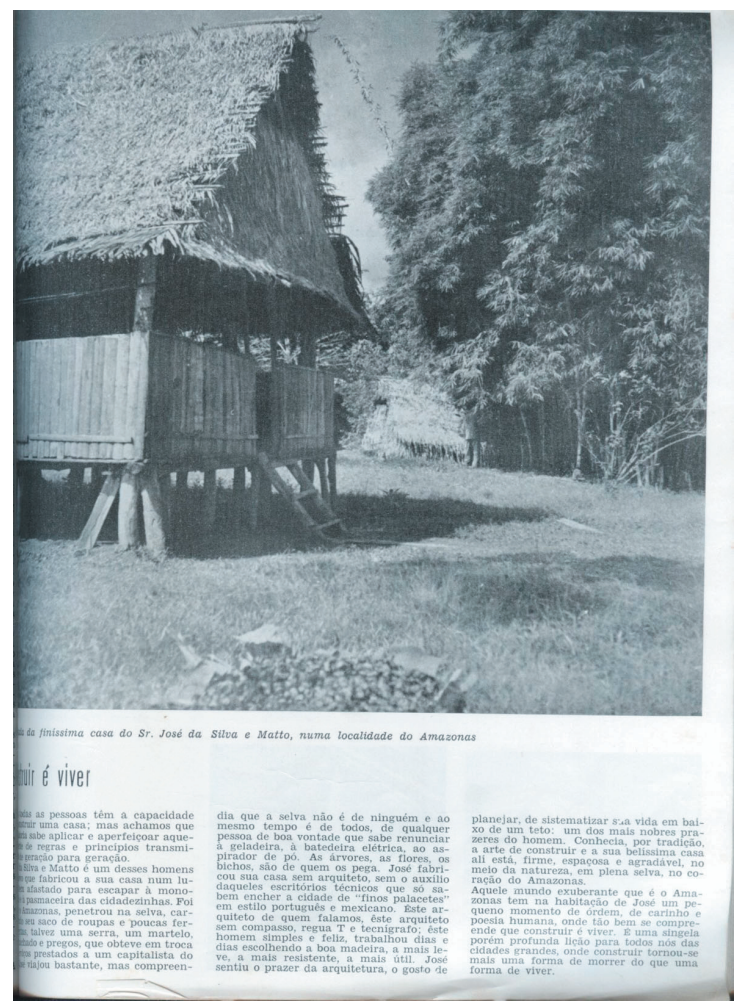

71 e 72 . "Construir é viver" ápresenta uma série de fotografias realizadas por Roberto Maia, que revelam as etapas construtivas da casa contruída no Amazonas pelo Sr. José da Silva e Matto, um homem do povo que.

"José fabricou sua casa sem arquiteto, sem auxilio daqueles escritórios técnicos que só sabem encher a cidade de 'finos palacetes' em estilo português e mexicano. Este arquiteto de quem falamos, esse arquiteto sem compasso, régua T e tecnígrafo; este home simples e feliz, trabalho dias e dias escolhendo a boa madeira, a mais leve, a mais resistente, a mais util. José sentiu o prazer da arquitetura, o gosot de planejar, de sistematizar sua vida, em baixo de um teto: um dos mais nobres prazeres do homem. Conhecia, por tradição, a arte de construir e a sua belíssima casa alí está, firme, espaçosa e agrdável, no meio da natureza, em plana selva, no coração do Amazonas."

Bo, Lina. "Construir é viver", Habitat n0 7, abr. / jun. 1952, p. 3.

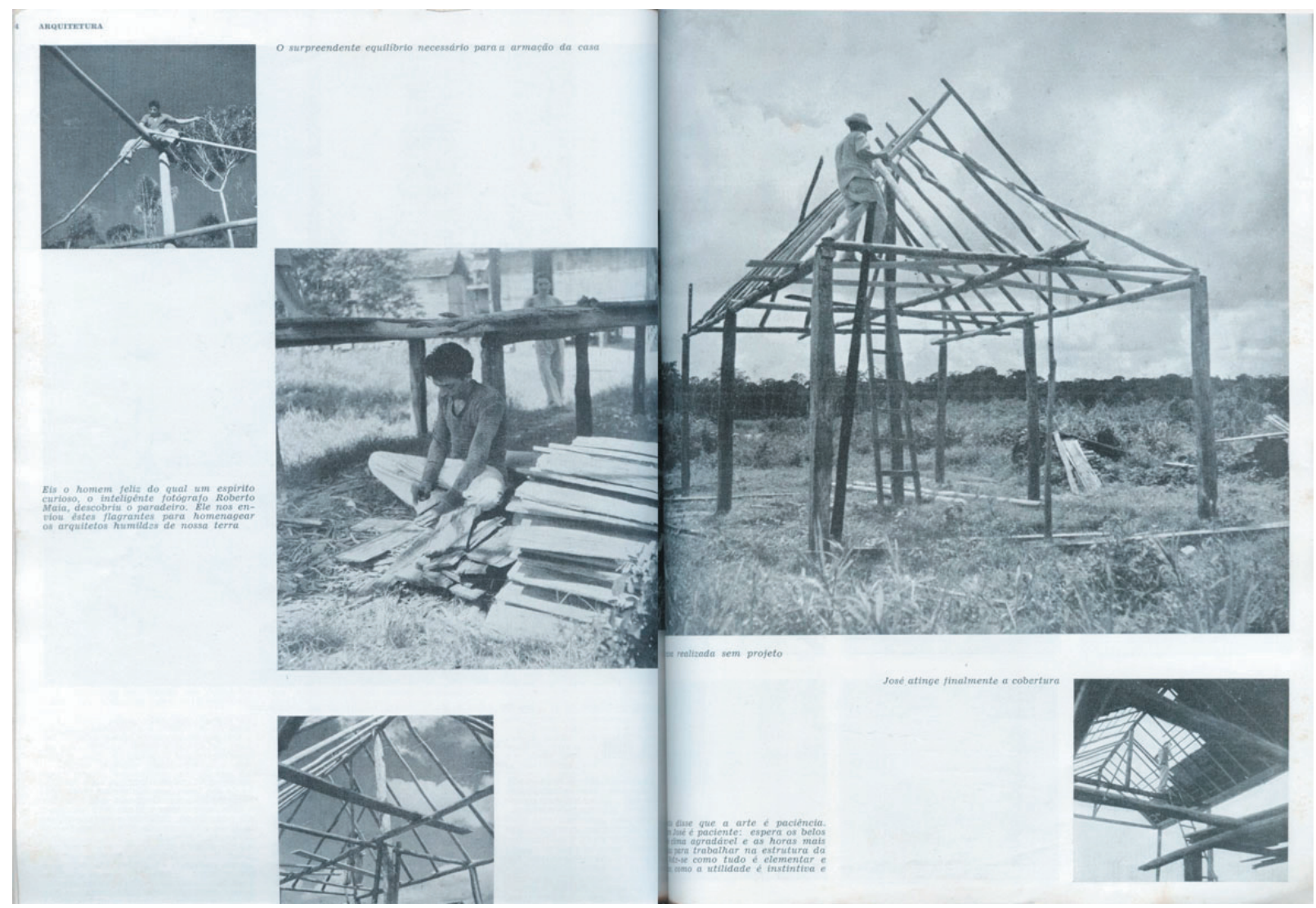


pescador, construída dentro de una verdad clara, indiscutible; mis ojos, sumidos en dia en la arquitectura, en el hecho arquitectural eternó, la han descubierto súbitamente. "!Esta casa, me exclamé, es un palácio! "61

E essa aproximação, entre o moderno e o popular é feita em Habitat a partir dos valores que compartilham: a coerência com o seu tempo, a racionalidade espacial, os não excessos, enfim, seu caráter sinceramente humano. Mesma expressão utilizada por Lina para qualificar a arquitetura de Vilanova Artigas e que caberia em igual medida para o povo do Amazonas.

Colaborando ainda para delinear 0 ambiente na Itália que precede a vinda de Lina e Pietro para o Brasil, 0 qual reafirma e intensifica o interesse pela valorização da tradição, podemos apontar a reconstrução no pós-guerra, pensada não mais "através da máquina", mas a partir do desenvolvimento de uma série de pesquisas sobre os modos de construir e os hábitos de morar das camadas populares, que demonstram a superação das bases do Futurismo e de alguns aspectos da arquitetura racionalista ${ }^{62}$ realizada no entreguerras.

“(...) A cidade, a sociedade, o mundo dos homens, de maneira ampla, agora haveriam de ser reconstruídos com especial atenção aos valores morais e à humildade estético-construtiva do homem que conseguira se preservar íntegro, afastado do conjunto de valores que levaram à situação em que agora se encontravam a maior parte das cidades européias. (...) A experiência da Guerra e o desenvolvimento das posturas políticas de Mussolini irão colocar arquitetos e intelectuais em uma posição oposta a alguns caminhos que antes se mostravam como possíveis". ${ }^{63}$

Na valorização da arquitetura anônima, vale destacar também a atuação de Lina, no pós-guerra, na revista A (1946), em conjunto com Carlo Pagani, Raffaelo Carrieri e Bruno Zevi, a qual enfoca os problemas da reconstrução a partir do resgate das tradições populares.

"Não há um homem primitivo, mas meios primitivos. Potencialmente a idéia é constante desde 0 começo". ${ }^{64}$

Com o mesmo discurso, Habitat, em "Construir é viver", apresenta a sabedoria do arquiteto do povo, que constrói com economia de meios e com profunda clareza construtiva, e retrata, por uma seqüência de imagens do fotógrafo Roberto Maia, as diferentes etapas da construção de uma casa na Amazônia onde tudo é elementar e orgânico, como a utilidade é instintiva e lógica.

${ }^{61}$ LE CORBUSIER [1929], Precisiones respecto a un Estado actual de la arquitectura e del urbanismo. Barcelona: Poseidon, 1978, p. 26.

${ }^{62}$ Sobre a arquitetura racionalista italiana do entreguerras Giorgio Ciucci apresenta o panorama em - Gli architetti e il fascismo. Architettura e città 1922-1944, Torino: Einaudi, 1989.

${ }^{63}$ PEREIRA (2001), op. cit., p.7.

${ }^{64}$ LE CORBUSIER [1923], Por uma arquitetura, São Paulo: Perspectiva, 1989, p. $43-4$. 
"Nem todas as pessoas tem a capacidade de construir uma casa; mas achamos que a maioria sabe aplicar e aperfeiçoar aquela série de regras e princípios transmitidos de geração para geração (...) José fabricou sua casa sem arquiteto, sem auxílio daqueles escritórios técnicos que só sabem encher a cidade de 'finos palacetes' em estilo português ou mexicano. Este arquiteto de que falamos, este arquiteto sem régua $\mathrm{T} e$ tecnígrafo; este homem simples e feliz, trabalhou dias e dias escolhendo a boa madeira, a mais leve, a mais resistente, a mais útil " .65

Neste sentido, o caráter dos ensaios críticos sobre a arquitetura popular presente na revista Habitat estabelece um diálogo com o discurso arquitetônico italiano que aponta na arquitetura popular não um léxico de formas e materialidades, mas exemplos do que possuem em comum com a arquitetura moderna. Desta forma, Habitat aproxima a tradição e o passado do presente, e ao pautar a arquitetura moderna ou a arquitetura popular, coloca em discussão uma mesma arquitetura humana e coerente com o seu tempo $0^{66}$.

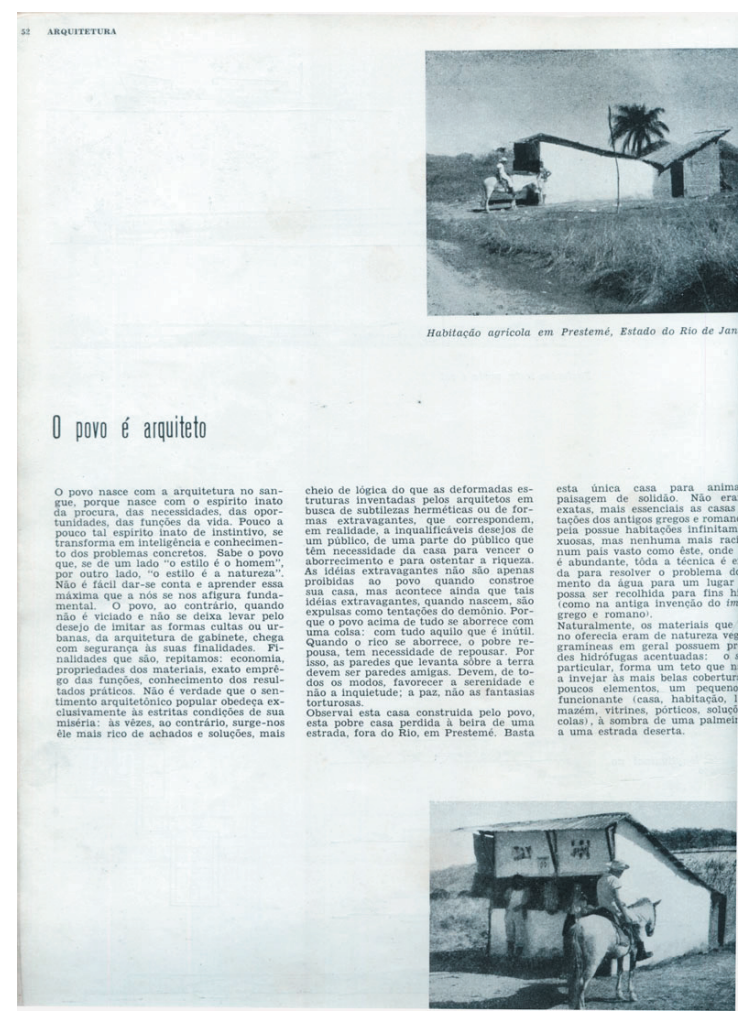

73. "0 povo é arquiteto" traz novamente os valores e "finalidades" da arquitetura: economia, propriedades dos materiais, exato emprego das funções, conhecimento dos resultados práticos, e um não a extravagância formal.

Na publicação que antecede a ausência de Lina e Pietro e o ingresso de Flávio Motta na direção, mais dois artigos fazem referência a ética construtiva existente na arquitetura anônima e que deveria perseguir a arquitetura moderna. Mas é no artigo "0 povo é arquiteto”, publicado no décimo número, provavelmente escrito por Lina antes de deixar o Brasil, que fica acentuada a crítica ao formalismo na arquitetura que irá servir de argumento para diversos artigos polêmicos sobre arquitetura moderna que serão apresentados a seguir.

"0 povo nasce com a arquitetura no sangue, porque nasce com o espírito inato da procura, das necessidades, das oportunidades, das funções da vida. (...) 0 povo, ao contrário, quando não é viciado e não se deixa levar pelo desejo de imitar as formas cultas ou urbanas, da arquitetura de gabinete, chega com segurança as suas finalidades. Finalidades que são, repitamos: economia, propriedades dos materiais, exato emprego das funções, conhecimento dos resultados práticos. Não é verdade que 0 sentimento arquitetônico popular obedeça exclusivamente às estritas condições de sua miséria: as vezes, ao contrário, surge-nos ele mais rico de achados e soluções, mas cheio de lógica do que as deformadas estruturas inventadas pelos arquitetos em

65 "Construir é viver", Habitat, São Paulo, nº 7, abr.-jun. 1952, p.3-10, artigo atribuído a Lina Bo.

${ }^{66}$ Observar que no Brasil, aproximação semelhante já tinha sido estabelecida por Lúcio Costa em 1938 em seu artigo "Documentação Necessária", publicado na revista do SPHAN, embora Lina em nenhum momento faça referência a esta discussão. 
busca de sutilezas herméticas ou formas extravagantes, que correspondem, em realidade, a inqualificáveis desejos de um público, de uma parte do público que tem necessidade da casa para vencer o aborrecimento e para ostentar a riqueza. (...)

Observai esta casa construída pelo povo, esta pobre casa perdida à beira de uma estrada, fora do Rio, e, Prestemé. (...) Não eram mais exatas, mais essenciais as casas e habitações dos antigos gregos e romanos. Pompéia possue habitações infinitamente luxuosas, mais nenhuma mais racional."

Este artigo será 0 último publicado em Habitat dedicado à arquitetura popular, ainda que indiretamente permaneçam os conceitos que essa seqüência procurou difundir quando a revista apresenta a produção contemporânea. A ausência no Brasil de Lina, autora desses textos, durante o período de um ano explica este fato. Quando volta, nas revistas de número 14 e 15, é possível perceber na ausência dessa discussão 0 presságio de uma mudança ${ }^{67}$, que se daria com a saída do casal na revista de número 16, no início de 1954.

${ }^{67}$ Nessas duas últimas publicações, que contam com a direção do casal, é possível perceber a alteração no projeto gráfico, evidente na capa e no editorial e a destinação de amplo espaço a divulgação de projetos urbanísticos. 


\title{
2.2. Habitat e a arquitetura moderna brasileira
}

\begin{abstract}
"Publicamos uma vista do Ministério de Educação do Rio de Janeiro, como incentivo para continuar combatendo contra a rotina, o lugar comum. Entendemos bem, o lugar comum não é somente aquele 'estilístico', é, também (e mais perigoso ainda), o assim chamado 'moderno'. 0 incitamento para combater o nascente 'vezo' modernistico - 'o antigo não serve mais, e então moços, para frente com o moderno se não queremos perder a partida' - a luta deve ser dirigida contra essa generalização perigosa, contra esta desmoralização do espírito de arquitetura moderna, que é um espírito de intransigência e do amor para o homem, que nada tem que ver com as formas anteriores e as acrobacias formalísticas. (...)"68
\end{abstract}

No texto acima, "Bela criança", Lina discorre sobre 0 abandono do antigo pelo moderno como um fato inquestionável, em que apenas as questões superficiais são absorvidas. Esta será uma entre as diversas vezes que a revista Habitat aponta para o risco da arquitetura moderna brasileira se transformar em mais um estilo. Como conseqüência da propagação e reconhecimento por todo o território nacional dos valores da arquitetura eleita pela crítica internacional, principalmente a partir da publicação do livro Brazil Builds, a produção moderna brasileira passa a ser aqui assimilada muitas vezes sem 0 entendimento de seus verdadeiros valores e significados. Por isso, ou contra o formalismo que a arquitetura moderna brasileira já começava a manifestar, Habitat adverte para o risco de sua academização e decadência, cuja conseqüência seria um esgotamento prematuro.

Mario de Andrade no momento do lançamento de Brazil Builds relata ${ }^{69}$ a grata surpresa que 0 livro deu aos brasileiros por ter nos revelado o valor da nossa produção de arquitetura moderna. A consciência fornecida pelos estrangeiros através dessa publicação pôde regenerar a nossa confiança em nós, e diminuir o desastroso complexo de inferioridade de mestiços que nos prejudica tanto. Portanto, foi graças ao olhar estrangeiro que a arquitetura moderna brasileira teve reconhecimento interno e popularizou-se ${ }^{70}$.

0 contato com essa produção a partir de seu resultado formal e a busca do up to date teve como conseqüência

${ }^{68}$ B0, Lina. "Bela Criança", Habitat, São Paulo, nº 2, jan/mar. 1951, p. 3.

${ }^{69}$ ANDRADE, Mario. Comentário sobre Brazil Buils [1943]. Arte em Revista, n.4. Arquitetura Nova. São Paulo: Centro de Estudos de Arte Contemporânea, ago. 1980, p. 25-28.

${ }^{70}$ No início dos anos 50, a arquitetura moderna brasileira passa a ser manchete de revistas semanais não especializadas, como a revista Manchete. Os artigos publicados procuram sempre ressaltar seus valores e o reconhecimento internacional. Ver, "Brasil, a potência dos arquitetos e a impotência da arquitetura", Manchete, Rio de Janeiro, n³3, 6 dez. 1952, p. 18. 
a utilização indiscriminada dos elementos plásticos a fim de fazer os edifícios "parecer" modernos. Desta forma, o brise-soleil, os pilotis e os pilares em V conquistaram os construtores das capitais que iniciaram um processo de disseminação desses elementos pelo interior do país. No entanto, não é para essa arquitetura anônima que a atenção de Habitat parece estar voltada, mas para uma arquitetura produzida por arquitetos. Ali estaria o risco: na produção de arquitetura realizada pelos mesmos arquitetos que a fizeram ser destaque.

Na defesa dos verdadeiros valores da arquitetura moderna brasileira Habitat irá se manifestar por meio de textos que alertam ao risco do formalismo, no qual terão destaque Lina e Abelardo de Souza ao lado da crítica internacional representada por Max Bill e Walter Gropius. Também trabalhando nessa defesa, a eleição e a publicação de uma produção de arquitetura que fizesse honrar o título de moderna.

A arquitetura moderna que interessa a Habitat apresenta os princípios que a fazem uma arquitetura artisticamente social; os mesmos que já vimos destacados na arquitetura popular. Assim, as relações entre modernidade e brasilidade presente na produção moderna brasileira são valorizadas com os princípios internacionais que convivem ao lado de elementos e experiências que particularizam essa produção como nacional.

“(...) A arquitetura contemporânea brasileira não provem da arquitetura dos Jesuítas, mas do 'pau a pique' do homem solitário, que trabalhosamente cortara os galhos nas florestas, provém da casa do 'seringueiro', com seu soalho de troncos e 0 telhado de capim, é aludida, também ressonante, mas possue (sic) em sua resolução furiosa de fazer, uma soberbia e uma poesia do homem do sertão, que não conhece as grandes cidades da civilização e os museus, que não possue (sic) a herança de milênios, mas suas realizações - cuja concretização foi somente possível por esta sua soberbia esquiva - fazem deter o homem que vem de países de cultura antiga." 71

Habitat procura apontar o valor da utilização de elementos tradicionais não de maneira saudosista, mas como experiências anteriores que ao serem incorporadas a produção contemporânea a transforma numa arquitetura com características próprias e atuais. Assim, como demonstramos anteriormente, são os princípios da racionalidade, da simplicidade, do respeito às técnicas construtivas, ao clima e aos costumes que une a produção contemporânea à arquitetura popular.

E por acreditar na existência de uma produção baseada em princípios e valores que fazem com que a arquitetura brasileira seja coerente com o homem no seu tempo, a revista sai em defesa da nossa arquitetura. No texto já citado, "Bela criança", Lina dirigi a seus amigos europeus esta defesa:

${ }^{71}$ BO, Lina, "Bela Criança", op. cit. 


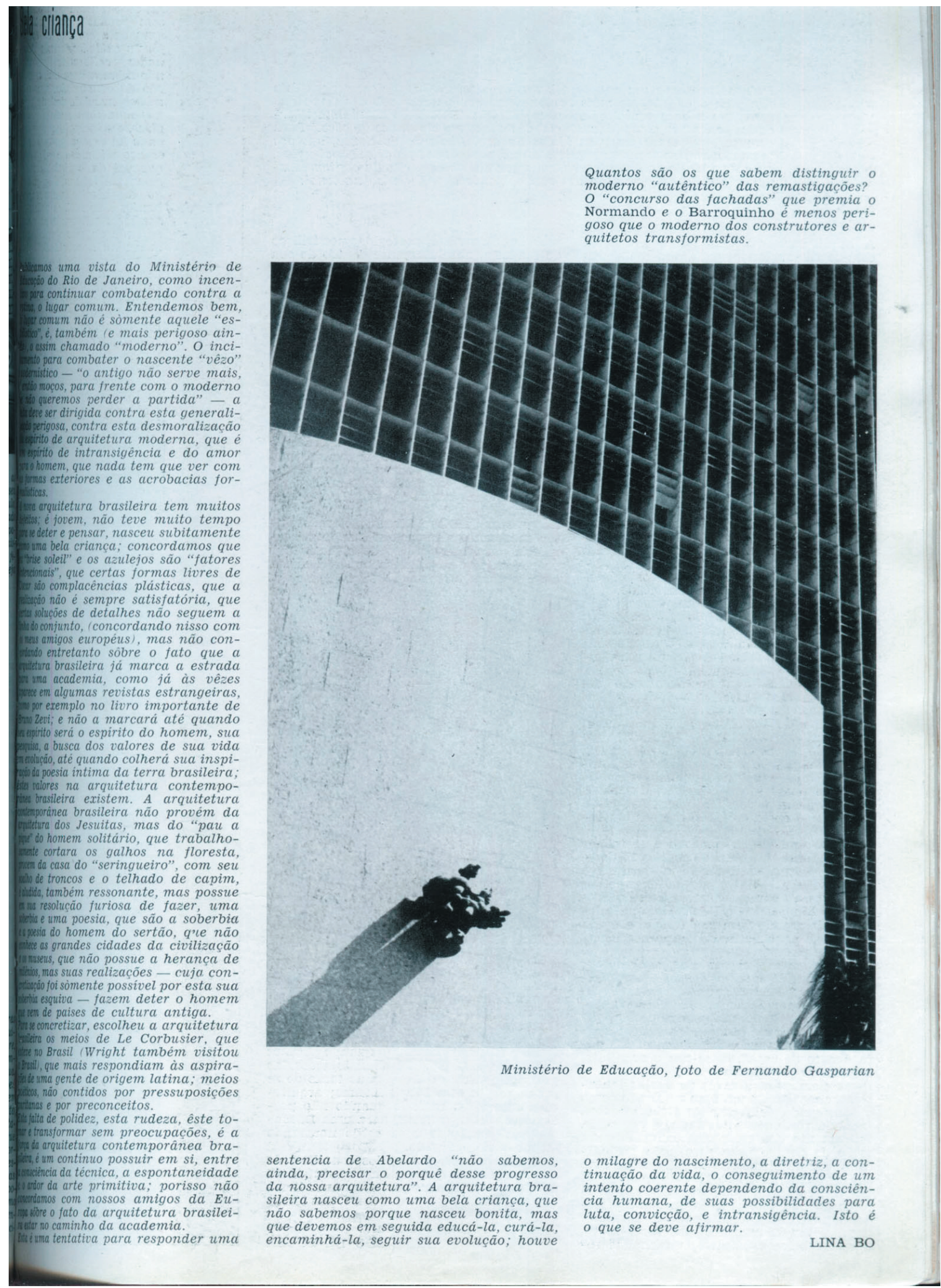

74. 0 artigo "Bela criança" abre a revista Habitat $n^{0}$ 2, edição que irá dedicar o maior número de artigos ( 9 ) em torna da discussão da aquitetura moderna brasileira. Neste Lina dialoga com a crítica internacional que já realizava críticas a produção brasileira. 
“(...) mas não concordamos entretanto sobre o fato que a arquitetura brasileira já marca estrada para uma academia, como já as vezes aparece em algumas revistas estrangeiras, como por exemplo no livro importante de Bruno Zevi; e não a marcará até quando seu espírito será o espírito do homem, sua pesquisa, a busca dos valores da sua vida em evolução, até quando colherá sua inspiração da poesia íntima da terra brasileira; estes valores na arquitetura contemporânea brasileira existem. (...)"

Como retrato dessa arquitetura, Habitat assume também o Ministério da Educação e Saúde (1937-1945) como símbolo. No edifício onde há os elementos que caracterizam a arquitetura de Le Corbusier, como a planta-livre, os pilotis, o terraço-jardim, entre outros, tem destaque os elementos que o particularizam, como 0 brisesoleil, os painéis de azulejos e o jardim de Burle Marx. Elementos que do ponto de vista de Habitat devem ser lidos como o respeito às características e condições locais e, portanto, empregados com viés técnico e não estético.

0 texto atribui à juventude da arquitetura brasileira - nascida não da influência jesuítica, mas das características locais e do homem do sertão, que para concretizá-la escolheu os meios da arquitetura de Le Corbusier que esteve no Brasil e não de Wright, que também esteve - a responsabilidade por alguns de seus defeitos e características.

"Esta falta de polidez, esta rudeza, esse tomar e transformar sem preocupações, é a força da arquitetura brasileira, é um contínuo possuir em si, entre a consciência da técnica, a espontaneidade e 0 ardor da arte primitiva; por isso não concordamos com nossos amigos da Europa sobre o fato da arquitetura brasileira estar no caminho da academia."

Segue nas páginas da mesma edição (Habitat n² 2, jan./mar. 1951) o artigo "Nossa arquitetura", de Abelardo de Souza, o qual discorre sobre as características particulares da arquitetura moderna brasileira cada vez mais distante das que lhe serviram de modelo, principalmente da alemã e francesa, ao humanizar-se. Destaca a contribuição do Serviço do Patrimônio Histórico, com a orientação de Lúcio Costa, na conquista da "completa emancipação arquitetônica" e afirma o caminho certo trilhado pelos arquitetos.

"Não sabemos, ainda, precisar, o porquê desse progresso na nossa arquitetura. Não temos a cultura européia, não temos a indústria americana, não temos a tradição dos povos mais antigos e apesar de tudo isso, temos uma arquitetura melhor orientada no seu verdadeiro sentido, mais plástica na sua beleza e, sobretudo mais humana". ${ }^{72}$

No desenvolvimento dessa arquitetura aponta o brise-soleil, que apesar de ter utilizações equivocadas por

${ }^{72}$ SOUZA, Abelardo, "Nossa arquitetura", Habitat, São Paulo, nº 2, jan./mar. 1951, p. 4. 


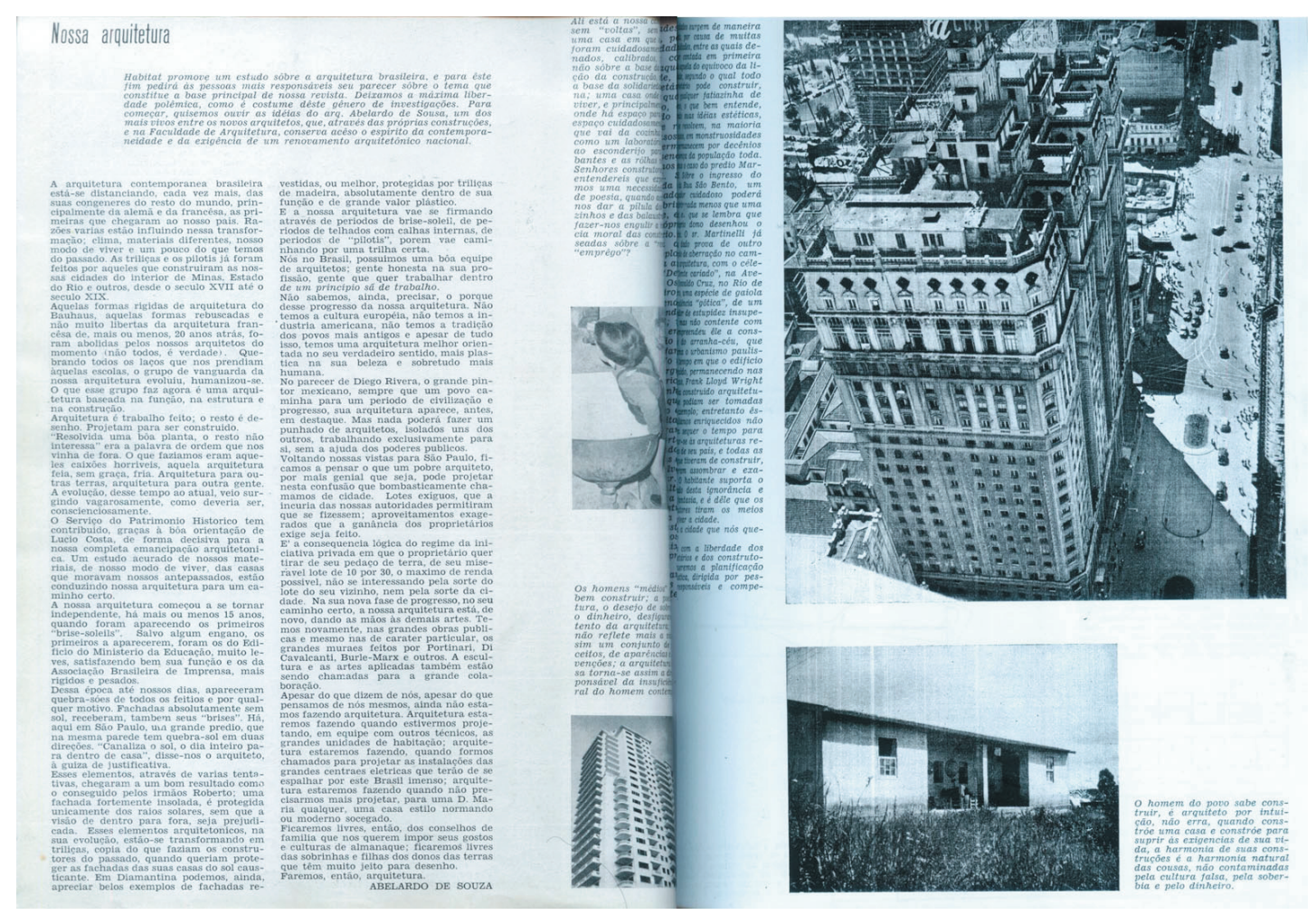

75 . Em "Nossa arquitetura", Abelardo de Souza afirma o caráter ahistórico da bem sucedida arquitetura moderna brasileira e convoca a administração publica para conter o crescimento desenfreado da cidade de São Paulo.

alguns, na sua evolução transformou-se em treliças de grande valor plástico, inspirada nos construtores do passado. Evoluções conseqüentes de um grupo de arquitetos que trabalha dentro do princípio são de trabalho.

Em "Construir com simplicidade"73 mais uma vez Lina faz referência ao risco da utilização do "moderno" como linguagem. Pretexto para exacerbação formal que aproximaria essa "arquitetura" do barroco em que é possível "viagens ao reino da extravagância, do insípido, do inútil, do incoerente, enfim. (...) no espaço arquitetônico, não é a forma que estabelece os motivos, mas é a função que se traduz em forma".

Nesta página, ilustrada pela imagem de uma residência simples acompanhada da nota que a descreve como Casa de mestre-de-obra em São Paulo, a revista chama a atenção para o risco de ao ignorar as produções exemplares e solitárias presentes fora das metrópoles, o homem transforma o pujante crescimento imobiliário em desculpa para uma produção de arquitetura descomprometida com os princípios que a deveriam reger. Neste sentido:

${ }^{73}$ BO, Lina. “Construir com simplicidade”, Habitat, São Paulo, n 7, out./dez. 1952, p. 15. 
"Constrói-se, constrói-se também 'modernamente'. Mas, antes de mais nada, é preciso estabelecer o que é que se entende por 'moderno'.

Há muitos sintomas alarmantes de que 'moderno' acabe por ser treinamento gráfico, preguiça, brincadeira, e muito de extravagância. Ora, se há um terreno em que todos estão de acordo, em admitir que nele não há lugar para extravagância, em que se deve combater a renuncia a todo esforço intelectual, esse terreno é 0 da arquitetura. No Brasil, porém, há indícios de que muitos arquitetos, alguns de renome, fazem um grande esforço, não de inteligência, mas de exibição.

(...) Entrou em voga a moda de fazer formas ao invés de construir casas. Ao invés de estudar o emprego funcional dos materiais, inventa-se o emprego plástico dos materiais, a fim de adaptá-los a garatujas, ângulos, cotovelos, losangos. (...) Plantas e cortes, relevos e perfis são traçados em relação a desenhos abstratos. Em determinado sentido é este um aspecto de baroquismo (sic), desde que entendamos por baroco (sic), não 0 atribuído de grandiosa circunstancia histórica, mas o vírus de uma baixa cultura, que convida a viagens ao reino da extravagância, do insípido, do inútiu do incoerente enfim. (...) no espaço arquitetônico, não é a forma que estabelece os motivos, mas é a função que se traduz em forma.

(...) 0 critério de forma bela e da forma não bela é um equivoco deletério. Se os homens que por primeiro usaram a roda tivessem julgado que o retângulo áureo é mais belo do que circulo, os homens até hoje estariam se locomovendo com os próprios pés. (...)".

Sabemos que 0 artigo faz referência, entre outras, a arquitetura de Niemeyer, também naquele momento alvo da crítica internacional. 0 reconhecimento e louvação da arquitetura brasileira por parte de uns, sofreu também ataques de outros. Entre os que realizaram ácidas criticas, podemos destacar Bruno Zevi, Nikolaus Pevsner e Max Bill. Este último tem nas páginas de Habitat espaço em três momentos distintos.

Max Bill, antigo aluno da Bauhaus e então diretor da Hochschule fur Gestaltung, na Alemanha, será júri da II Bienal (1953) e neste momento o principal porta-voz da crítica internacional mais reticente a arquitetura moderna brasileira. Sempre contundente e provocador, Bill não poupa argumentos em exercer com seriedade seu compromisso crítico, dirigindo neste momento observações à arquitetura moderna brasileira que talvez até hoje não tenham sido superadas ${ }^{74}$.

Habitat, entre elogios, divulga a premiação de Max Bill com a escultura "Unidade Tripartida" na I Bienal de São Paulo em 1951. 0 mesmo exemplar publica também um artigo do designer intitulado "Beleza provinda da função e beleza como função", em que discute a responsabilidade a que a forma estaria submetida, seu sentido social e, em contrapartida, o desejo de chegar a uma nova expressão formal.

"Tal ficou a situação até hoje, e até um certo ponto também na técnica. Formas novas, e sentidas como artísticas, surgem por toda parte e não do puro senso de responsabilidade em relação ao futuro consumidor, mas de uma necessidade de forma universalmente difundida"75.

\footnotetext{
${ }^{74}$ Diversos autores fazem referência ao mal-estar decorrente às críticas realizadas por Max Bill naquele momento, malestar que hoje reflete a dificuldade no Brasil para a assimilação e, portanto, realização de uma crítica madura em relação à produção de arquitetura contemporânea. Ver "A opinião estrangeira”, in: Segawa (2002), op. cit.

${ }^{75}$ BILL, Max. "Beleza provinda da função e beleza como função", Habitat, São Paulo, nº 2, jan./mar. 1951, p. 61.
} 
Segundo 0 autor, a mudança sofrida pelas formas muitas vezes não decorre da mudança da função, mas por uma necessidade estética, ao que chama de "beleza entendida como função". 0 texto de Max Bill chama a atenção para os produtos falsamente modernos oriundos da prancheta dos industrial-designers, em que não há nenhuma preocupação técnica. Atribui a eles a responsabilidade sobre nossa cultura visual, assim como aos arquitetos, a responsabilidade sobre 0 desenvolvimento das cidades, os quais já começavam a delinear uma unidade de estilo advindo "das formas disciplinadas, consoantes a seu fim".

Dois anos depois, a convite do Ministério das Relações Exteriores, Max Bill vem ao Brasil como conferencista e coloca a público uma das mais importantes críticas à arquitetura moderna brasileira proferidas até então no artigo "Max Bill, o inteligente iconoclasta". Como transcrição de uma entrevista ao repórter Flávio d’Aquino, publicada originalmente na revista Manchete e no jornal Diários, 0 artigo expõe a arquitetura brasileira a duras observações que fizeram com que a partir deste episódio 0 artista suíço, a quem até então 0 Brasil não poupava elogios, passasse a julgar sua competência ${ }^{76}$. Julgamento avaliado por Habitat como imatuturo: “(...) Num país novo como o Brasil, isto é natural e pertence ao fenômeno da juventude".

A mesma preocupação que apresenta para com 0 desenho industrial em relação à utilização gratuita da forma como meio de alcançar um pseudoperfil moderno, Max Bill indica, em relação à arquitetura brasileira consagrada, que formas e elementos estariam sendo utilizados sem coerência e em edifícios sem fins sociais, afastando assim seu verdadeiro espírito moderno. Bill clama pela lógica e pela função, a exemplo de Gropius o qual "jamais esquece a importância social da arquitetura". Assim, categoriza Afonso Reidy, com sua obra para o Conjunto Pedregulho, como o mais importante arquiteto brasileiro e convida os arquitetos a enfrentar o problema da habitação popular.

76 Inconformados com as declarações de Max Bill em relação às críticas a arquitetura moderna brasileira, diversos periódicos passarão a desqualificar as atividades profissionais do arquiteto, como exemplo 0 artigo "Max Bill afastado do júri da bienal" publicado no jornal carioca 0 Diário de Notícias, em 13 de setembro de 1953.
76. A Exposição da obra de Max Bill no MASP, é divulgada em Habitat no mesmo artigo que publica 0 texto do designer suiço "Beleza provinda da função e beleza como função".

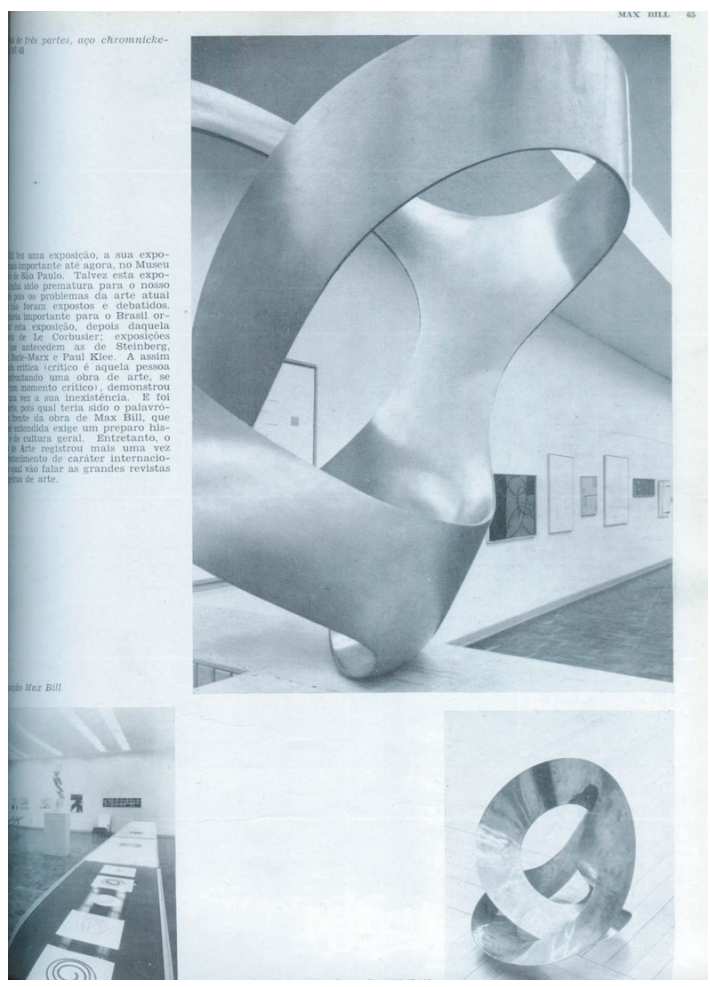


Na entrevista, Max Bill comenta as obras que visitou no Brasil, e, em especial, faz críticas ao Ministério da Educação quanto à proporção, ao partido adotado e ainda posiciona-se contra a utilização das pinturas murais na arquitetura, simplesmente decorativas e desprovidas de seu sentido primordial que seria 0 de educar ${ }^{77}$. A crítica estende-se também a obra de Oscar Niemayer no Conjunto da Pampulha:

"(no que) padece em pouco deste amor ao inútil, ao simplesmente decorativo. (...) Niemeyer apesar de seu evidente talento, projetou-o por instinto, por simples amor à forma pela forma; elaborou-o em torno de curvas caprichosas e gratuitas cujo sentido arquitetural apenas para si mesmo é evidente". ${ }^{78}$

Ao encerrar a entrevista, Max Bill declara: "Para mim, em matéria de arquitetura, existe somente a moderna. Se critico a arquitetura brasileira é porque ela me favorece matéria para tal, o que significa dizer que ela é importante"79.

Esta entrevista é apresentada em Habitat por um breve texto que introduz a polêmica suscitada por Max Bill, que comenta seus reflexos no meio arquitetônico e destaca a importância da crítica para o amadurecimento da produção brasileira a fim de evitar seu ingresso numa rotina acadêmica a que Bruno Zevi já fazia referência em seu livro História da arquitetura moderna.

No ano seguinte Habitat chama novamente a atenção para as palavras do arquiteto suíço ao publicar a conferência "0 arquiteto, a arquitetura, a sociedade" 80 , realizada no ano anterior na Faculdade de Arquitetura e Urbanismo da Universidade de São Paulo. Lina comenta a repercussão "deformada" e a importância das críticas que Max Bill realizou, críticas que deveriam ser vistas como "coisa universal, um patrimônio da humanidade, e não um fato de fronteiras".

Na conferência, Max Bill, como na entrevista dada a Flávio d’Aquino, elogiou o "êxito absoluto no plano urbanístico, arquitetônico e social de Pedregulho e alertou para o risco da arquitetura brasileira transformar-se em 'um academismo moderno' através da utilização dos quatro elementos - a forma livre, o 'pan de verre' e o 'brise soleil' e 'os pilots' - como fórmula. Atacou novamente o famoso Ministério da Educação, no Rio de Janeiro e criticou duramente as diversas formas que os "pilotis" vinham adquirindo, todas distantes de sua função. Seria um sinal do "fim da arquitetura moderna"?

\footnotetext{
${ }^{77} \mathrm{Na}$ crítica a utilização dos azulejos na arquitetura moderna brasileira, Bardi se alinha, expondo a mesma opinião diversas vezes em Habitat.

${ }^{78}$ AQUINO, Flávio, "Max Bill, o inteligente iconoclasta", Habitat, São Paulo, n 12, jul./set. 1953, p. 34.

79 "Max Bill, 0 inteligente iconoclasta" (1953), op. cit..

${ }^{80}$ MAX, Bill. "0 arquiteto, a arquitetura, a sociedade", Habitat, São Paulo, n 14, jan./fev. 1954.
} 
Na conferência o designer utilizou-se como exemplo de um edifício comercial em construção que visitara em São Paulo para estabelecer duras críticas à arquitetura que vinha se realizando na cidade:

"(...) Quando entrardes no local da obra, entireis imediatamente uma formidável mistura de sistemas construtivos, de pilotos largos, de pilotis finos, de pilotis de formas fantásticas, sem nenhuma finalidade construtiva, colocados em diferentes direções, e, finalmente, muros inteiros; tudo em cimento armado. Os muros e os pilotis entrecruzam-se sem razão, as formas destroem-se, cortam-se. É a desordem, a mais gigantesca, que jamais vi no local de uma obra. Eu me pergunto (...) como num país onde existe um grupo CIAM (Congressos Internacionais de Arquitetura Moderna), uma Revista como Habitat, e uma bienal de arquitetura, pode-se chegar a construções tão selvagens (...)? Prédios deste gênero nascem de um espírito que não tem modéstia; não tem responsabilidade com as necessidades humanas. (...)" ${ }^{81}$

Na conferência, ainda com o fim de resgatar os princípios da arquitetura moderna, relembra a função social da arquitetura: "1) a arquitetura deve ser, antes de tudo, modesta e clara. 2) a arquitetura é uma arte, quando todos os seus elementos (a função, a construção e a forma), estão em perfeita harmonia. 3) a arquitetura é uma arte social, e, como tal, deve estar a serviço do homem".

Sabemos que o edifício a que Max Bill se refere é o Califórnia, que naquele momento estava sendo construído pelo Banco Nacional Imobiliário (BNI). Mas as críticas do designer, realizadas no Brasil e veiculadas em Habitat,

77. A entrevista de Max Bill ao repórter Flávio d'Aquino, publicada também em outros periódicos de maior circulação e que causou grande repercussão.

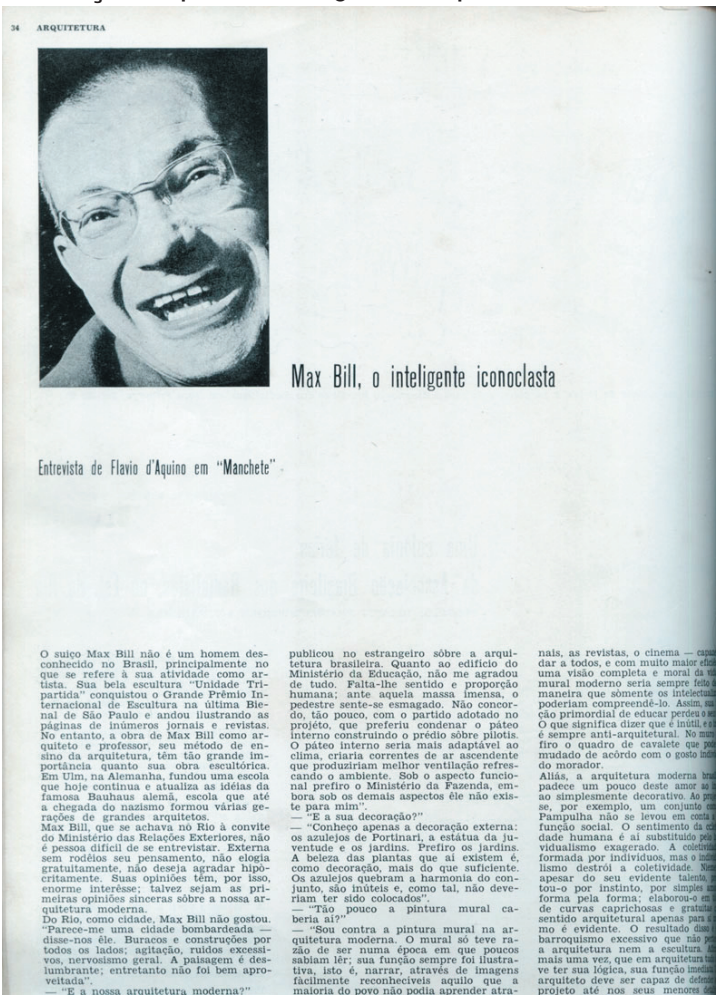

alcançam também as revistas estrangeiras. Em outubro de 1954 Bill publica na Architectural Review outro ataque à arquitetura brasileira, desta vez explicitamente direcionada aos edifícios do Parque do Ibirapuera, onde destaca a utilização dos pilares em $\mathrm{V}$.

"(...) somos justamente nós, os arquitetos, que
devemos dar uma nova solução às necessidades
humanas. Mas como se apresenta esta nova
forma? Tem ela realmente, os pilotis, a forma
livre, os brises-soleil, e os 'pans de verre'? é
ela tão fotogênica e espetacular? Não acredito.
(...)" 82

Estas palavras tiveram repercussão entre os arquitetos brasileiros, que, como Lúcio Costa ${ }^{83}$, iniciam um

81 "0 arquiteto, a arquitetura, a sociedade" (1954). op. cit..

82 BILL, Max, "0 arquiteto, a arquitetura e a sociedade", Habitat, São Paulo, nº 14, jan./fev. 1954.

${ }^{83}$ Ver COSTA, Lúcio. "Sobre a arquitetura", Porto Alegre: 
caloroso debate cujas conseqüências originaram um vezo a crítica, que até hoje pode ser visto entre os profissionais brasileiros. Niemeyer também como resposta a "provocação" estrangeira publica uma autocrítica anos depois, em 1958. Em "Depoimento" ${ }^{4}$, publicado na revista Acrópole, 0 arquiteto faz um balanço de sua produção e anuncia uma mudança a fim de alcançar maior pureza e simplicidade.

Mas não é a penas Max Bill que aparece com um olhar estrangeiro sobre a produção nacional. Também as palavras de Alvar Aalto e Walter Gropius têm espaço em Habitat ${ }^{85}$. Na mesma edição em que é relatada a conferência do designer suíço, 0 artigo "Dois mestres da arquitetura contemporânea falam aos arquitetos brasileiros" transcreve os discursos de Aalto e Gropius proferidos durante o IV Congresso Brasileiro de Arquitetos $^{86}$ realizado em São Paulo. 0 congresso foi parte das comemorações do IV Centenário da cidade, paralelo à II Bienal Internacional de Arte e Arquitetura, na qual Gropius recebeu homenagem com uma sala especial. Embora se mostre bastante crítica em relação as Bienais e aos eventos em torno dos quais se realizam as comemorações do aniversário de São Paulo, Habitat reconhece seu interesse e dedica longas matérias sobre eles ao longo da revista de número 14 (janeiro/fevereiro 1954), que tem publicação paralela ao evento.

Ao IV Congresso Brasileiro de Arquitetos a revista destina um artigo de Abelardo de Souza, que escreve como membro da comissão organizadora uma espécie de "relato-balanço", no qual introduz as palavras dos estrangeiros que estiveram presentes no evento graças à "coincidência" com a agenda da Bienal.

Abelardo, à medida que descreve 0 Congresso que reuniu mais de 470 congressistas, entre os quais cinqüenta eram vindos das Américas e da Europa, lamenta a não realização da exposição de arquitetura inicialmente planejada e o baixo número de teses expostas. Conclui que as resoluções do evento repetem as apontadas em congressos anteriores e elogia a "recomendação" de uma autocrítica diante da produção brasileira; aponta os riscos de um possível "exagero" diante da proposta de desenvolvimento em torno da arquitetura tradicional brasileira e sua divulgação, e apóia movimentos que visam ao estudo da "cultura nacional". Abelardo crítica

Centro dos Estudantes Universitários de Arquitetura, 1962.

${ }^{84}$ NIEMEYER, Oscar. "Depoimento", Acrópole, São Paulo, nº 237, jul. 1958.

${ }^{85} \mathrm{Há}$ ainda outros momentos em que a crítica internacional em relação a produção brasileira aparece. Em "Jovem brasileiro na Europa" (Habitat, $\mathrm{n}^{07}$ ), Jorge Wilheim descreve entre notas de viagem um debate sobre a arquitetura brasileira na Associazione per una Architettura Organica, que contou com a participação de Bruno Zevi e Piccinato. No evento, a arquitetura brasileira teria sido duramente criticada pelo excesso de formalismo, nenhuma relação construtiva, ausência das características da arquitetura tradicional local e ainda, pela mera transposição dos cânones de Le Corbusier.

${ }^{86}$ Sobre 0 assunto ver Anais do IV Congresso Brasileiro de Arquitetos. São Paulo 16-27 janeiro 1954. 
ainda o tema proposto para o V Congresso, "História da Arquitetura no Brasil", a realizar-se na Bahia, como uma questão para ser discutida dentro das universidades e não em um Congresso.

"(...) Por isso a crítica ao êxito do Congresso é uma crítica aos arquitetos brasileiros que produzem no campo do individualístico, sem terem enfrentado ainda o problema do trabalho cooperativo, especialmente naquilo que diz respeito ao problema urbanístico e aos programas edifícios de ordem social." ${ }^{87}$

É também com um viés marcadamente social, o mesmo pelo qual suas obras se particularizam, que Aalto e Gropius apresentam no Congresso os problemas arquitetônicos em bases "morais", como dever social e responsabilidade coletiva.

Aalto procura estender suas teorias à realidade brasileira. Aponta a necessidade do planejamento, primeiramente de grandes regiões, depois das cidades e só então da habitação. Alerta para o risco de ao projetar todos os detalhes, 0 arquiteto limitar a liberdade do indivíduo e coloca como desafio a humanização da arquitetura, possível com o "planejamento elástico". Nesse mesmo sentido, Aalto fala também de uma "padronização elástica, onde o benefício de métodos industriais são sincronizados com a possibilidade de criar ricas variedades ao invés de uniformidade" 88 .

Gropius aborda o papel do arquiteto na sociedade industrial e a indissociabilidade da arte e da técnica. Aponta o papel degradante atribuído ao operário, utilizado como instrumento da indústria e razão da decadência das relações sociais. Gropius analisa a trajetória do afastamento da indústria pelo arquiteto como conseqüência de seu temor em perder o papel de artista criador em função dos novos mecanismos de padronização, levando-0 ao afastamento do processo de produção e da coordenação que the cabia até a Idade Média. 0 arquiteto se autocondenou em um profissional supérfluo e apenas a reaproximação entre o projeto e o processo construtivo, a participação na produção dos componentes industriais e o entrosamento entre os profissionais envolvidos 0 faria sair deste papel.

Seguindo o mesmo intuito de chamar à ação os arquitetos, o artigo "Casas eles também precisam" é publicado logo após as palavras de Aalto, Gropius e Max Bill que proclamam uma arquitetura racional com fins sociais. 0 artigo-denúncia apresenta a imagem em grande formato de um cortiço, fotografia de Alice Brill que retrata as más condições de vida da população e colabora com o autor que convoca os arquitetos a solucionar as

${ }^{87}$ SOUZA, Abelardo. "IV Congresso Brasileiro de Arquitetos", Habitat, São Paulo, nº 14, jan./fev. 1954, p. 23.

${ }^{88}$ AALTO, Alvaro. "Dois mestres da arquitetura contemporânea falam aos arquitetos brasileiros", Habitat, São Paulo, $n^{0}$ 14, jan./fev. 1954, p. 25. 
questões relativas ao déficit habitacional e à falta de planejamento urbano:

"Numa época de retórica, por excelência, quando o regime fascista promoveu na Itália a política das arquiteturas retórico-coloniais, um arquiteto da resistência da arquitetura moderna, morto num campo de concentração nazista, Giuseppe Pagano, estigmatizou a retórica vazia da arquitetura monumental fascista com as seguintes palavras, movido por uma mentalidade não estreitamente política ou acomodante e sim doravante universal: 'Vale mais a sarjeta de um bairro do que um monumento'." ${ }^{89}$.

A função social da arquitetura, que na revista é sempre destacada, teve como grande palco de discussão os CIAMs (Congresso Internacional de Arquitetura), realizados a partir do final da década de 1920 na Europa, onde a troca de experiências e o debate de idéias se fazem. O I CIAM, realizado em La Sarraz, Suíça, em 1928, já aponta 0 interesse pela discussão das questões habitacionais, com 0 estudo da habitação econômica, propagada principalmente pelos arquitetos da Nova Objetividade alemã, da qual Max Bill é legítimo sucessor. Essas questões são acentuadas no segundo encontro, realizado em Frankfurt, em 1929, cujo tema é "A habitação para o mínimo nível de vida". No III CIAM, realizado em Bruxelas, em 1930, o debate permanece dedicando 0 encontro para 0 agrupamento das células habitacionais em conjuntos residenciais, passando assim a incorporar às discussões as questões urbanísticas, como densidade e uso do solo. Mas é no IV CIAM, que contou com a presença de Bardi, que as discussões urbanísticas tiveram sua máxima.

Os CIAMs foram responsáveis por colocar o urbanismo como disciplina científica ao dedicar-se desde o primeiro encontro, ao estudo de soluções espaciais e técnicas capazes de melhorar a vida nas cidades industriais a partir da pré-fabricação e da racionalização. 0 IV CIAM, em 1933, teve como tema a Cidade Funcional. Neste, as questões urbanísticas foram organizadas em quatro elementos essenciais - habitação, trabalho, lazer e circulação -, aos quais condiciona o bom desempenho do conjunto ao cumprimento das necessidades específicas de cada categoria. Fruto desse encontro, a Carta de Atenas (1941), de Le Corbusier, constitui um dos principais documentos divulgadores das questões

89 "Casas eles também precisam", Habitat, São Paulo, n0 14, jan./fev. 1954, p. 29.
78. "Denúncia", uma fotografia de Alice Brill do cotidiano de um cortiço e 0 alerta para 0 déficit habitacional.

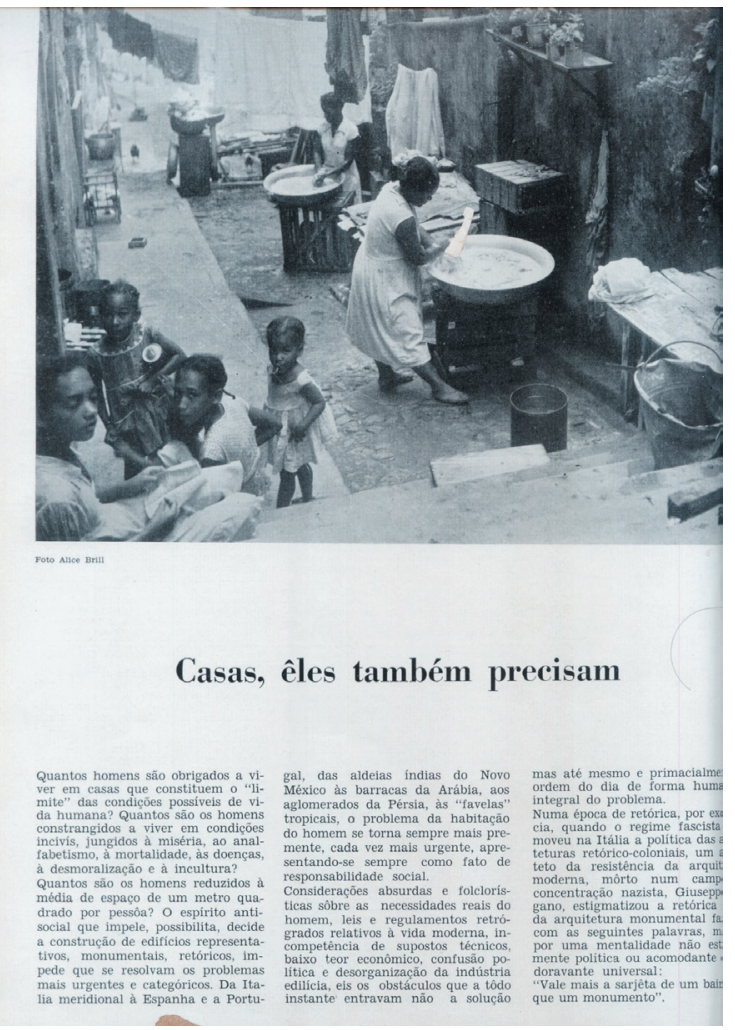


ali colocadas e caracterizou a urbanística moderna ${ }^{90}$.

Assim, as discussões urbanísticas presentes em Habitat alinham-se às discussões internacionais pautadas pelos CIAMs. É importante observar a proximidade de Bardi, que participou do IV Congresso no "Patris II", entre Marselha e Atenas como correspondente, jornalista e crítico de arte e arquitetura italiano. Oportunidade que 0 aproxima ainda mais do pensamento moderno e de figuras que o fundamentaram, como Le Corbusier $\mathrm{e}$ Gidion, e que se fazem presentes direta ou indiretamente na revista.

Vale ainda apontar que a representação brasileira nos CIAMs se faz a partir de 1929, quando Le Corbusier em visita ao Brasil, impressionado com o trabalho de Warchavchik ${ }^{91}$, 0 indica como delegado para a América Latina nos CIAMs. No entanto, o intercâmbio de experiências brasileiras e a atenção à arquitetura aqui realizada só iria acontecer após a realização do Pavilhão do Brasil na Feira Mundial de Nova York e da publicação do livro Brazil Builds ${ }^{92}$. Antes disso não há a inclusão de qualquer projeto brasileiro entre os trabalhos apresentados nos III e IV Congressos e tampouco a menção à produção brasileira no V CIAM (1937), um ano após a consultoria de Le Corbusier ao projeto do edifício do Ministério da Educação e Saúde Pública.

Mas é anterior aos congressos internacionais no Brasil a preocupação em relação ao crescimento desordenado das cidades, como vemos registrado no artigo de Rino Levi, de 1925, publicado no jornal O Estado de S.Paulo ${ }^{93}$. Nele, 0 arquiteto sugere que sejam adotados planos modernos de urbanização para regulamentar e disciplinar 0 crescimento de São Paulo. Apelo que, no entanto, não altera o curso dos fatos e mantém a cidade no mesmo padrão de crescimento e acentuado déficit habitacional.

É com as mesmas preocupações que a discussão relativa ao urbanismo permeia continuamente os artigos publicados em Habitat mais de duas décadas após as palavras de Rino Levi. As questões do desenvolvimento urbano e do crescimento econômico do país e a urgência de um planejamento que contenha a desenfreada

90 Os três primeiros CIAMs irão consagrar também como tema central a questão da habitação social, a habitação econômica, propagada principalmente pelos arquitetos da Nova Objetividade alemã, da qual Max Bill é legítimo sucessor. ${ }^{91}$ Data de 1928 a conclusão da residência do arquiteto Gregori Warchavchik, representando a primeira habitação modernista no país.

${ }^{92}$ No VI CIAM, em 1947, há a retomada do Congresso com um balanço da produção realizada nos últimos dez anos; nela o Brasil é representado por Henrique Mindlin, Gregori Warchavchik, Rino Levi, Álvaro Vital Brasil, Atílio Correia Lima e os irmãos Roberto.

${ }^{93}$ LEVI, Rino. "Arquitetura e estética das cidades", O Estado de S.Paulo, 15 out. 1925.

No momento em que publica este artigo, Rino Levi é ainda estudante de arquitetura do penúltimo ano na Escola Superior de Roma. 
expansão das cidades têm como foco a cidade de São Paulo. A revista mostra a dificuldade ou o desleixo do poder público em absorver em sua administração os problemas urbanos gerados pelo rápido crescimento populacional e a urgência de planos que contenham o interesse imobiliário que, em sua ganância, vinha desenhando a cidade. ${ }^{94}$

A preocupação com a cidade, tema tão caro para o movimento moderno, está presente na revista nas relações arquitetura-urbanismo que seus artigos apresentam. É constante em Habitat, mesmo nos artigos referentes à publicação de projetos de residência, a atenção às questões que envolvem o edifício na cidade, a legislação, a taxa de ocupação e recuos, a constituição de novos bairros, as relações topográficas e o entorno; questões que alinhavam e alimentam artigos dedicados aos mais diversos temas.

Logo no primeiro número Habitat publica um breve artigo intitulado "Do pequeno ao grande, numa corrida", no qual apresenta ao lado da imagem de uma pequena casa construída aos finais de semana por imigrantes italianos uma imagem noturna do centro da cidade de São Paulo. As imagens publicadas lado a lado servem de provocação e completam o texto que convoca os arquitetos a deter o crescimento vertiginoso da cidade de

${ }^{94}$ Conforme 0 artigo já citado de Abelardo de Souza, "Nossa arquitetura", Habitat, n 2.

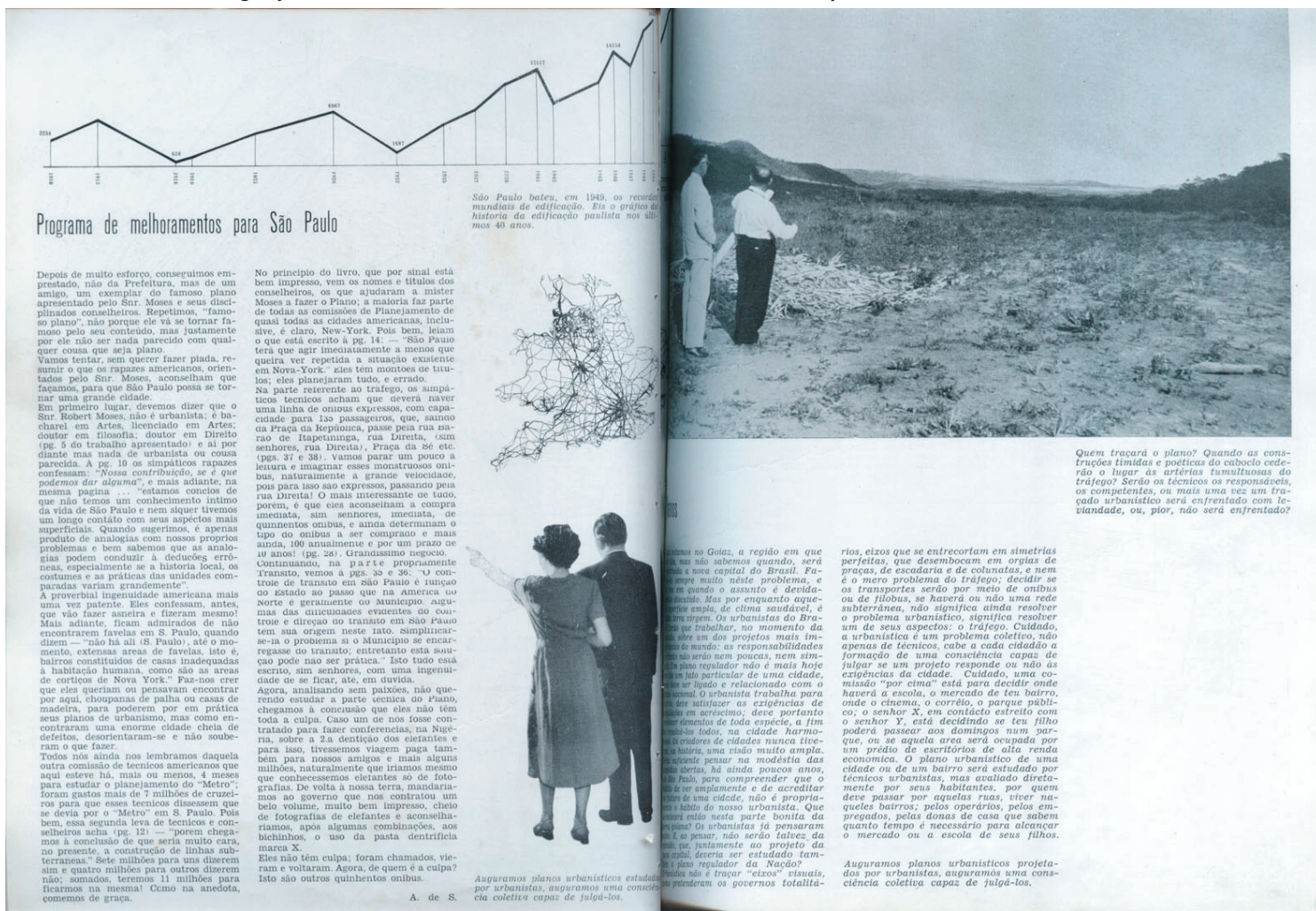

79. Em Habitat n 2, "Programa de melhoramentos para São Paulo" e "Planos", mais dois artigos escritos por Abelardo de Souza que apresentam questões urbanísticas. 
São Paulo por meio de um plano urbanístico. "Agora é uma questão de meses e dentro em pouco será uma questão de dias. Tem a palavra, urbanistas e arquitetos deste país"95.

No número seguinte, no artigo já citado "Nossa arquitetura", Abelardo de Souza convoca os arquitetos, juntamente com o poder público, a enfrentar as questões resultantes da expansão urbana apresentada pelas cidades, até então nas mãos apenas dos especuladores imobiliários. As imagens e notas que acompanham o texto expõem de forma agressiva, quase anedótica, os problemas urbanísticos da metrópole que São Paulo já se transformara. Fotografias retratam problemas infra-estruturais decorrentes da falta de abastecimento de água e esgoto, da insuficiente capitação de águas pluviais e da já saturada rede de transporte.

“(...) É a conseqüência lógica do regime da iniciativa privada em que o proprietário quer tirar de seu pedaço de terra, de seu miserável lote de 10 por 30, o máximo de renda possível, não se interessando pela sorte do lote do seu vizinho, nem pela sorte da cidade.(...)

Apesar do que dizem de nós, apesar do que pensamos de nós mesmos, não estamos fazendo arquitetura. Arquitetura estaremos fazendo quando estivermos projetando, em equipe com outros técnicos, as grandes unidades de habitação; arquitetura estarmos fazendo, quando formos chamados para projetar as instalações das grandes centrais elétricas que terão de se espalhar por este Brasil imenso; arquitetura estaremos fazendo quando não precisarmos mais projetar, para D. Maria qualquer, uma casa estilo normando ou moderno sossegado."

Essa preocupação moderna em relação às cidades é publicada na revista sob a responsabilidade de profissionais engajados aos ideais modernos, entre os quais podemos destacar o próprio Abelardo de Souza. Carioca de formação, mas com atuação em São Paulo, Abelardo tem em Habitat nº 2 (janeiro/março 1951) mais dois artigos que abordam questões urbanísticas. 0 primeiro, "Programa de melhoramentos para São Paulo", faz a crítica à contratação pelo poder público de técnicos urbanistas americanos. Segundo 0 autor, liderados por Robert Moses profissionais sem qualificação de urbanistas ou arquitetos e desconhecedores das características locais propuseram soluções equivocadas para os problemas urbanos existentes na cidade de São Paulo. 0 ensaio cita trechos do "Plano" que evidenciam as analogias entre os problemas encontrados nas cidades americanas e os de São Paulo, procurando deflagrar uma abordagem e condução errônea da cidade objeto.

No segundo artigo, intitulado "Planos", uma bela imagem do planalto central ilustra o texto que se desenvolve em torno da futura nova capital do Brasil. Chama a atenção para a necessidade de o plano da Capital estar relacionado a um plano nacional, um plano regulador da Nação que olhe para o futuro e que não exclua na sua realização a participação popular.

95 “Do pequeno ao grande, numa corrida”. Habitat, São Paulo, nº 1, p. 65. 
"Auguramos planos urbanísticos projetados por urbanistas, auguramos uma consciência coletiva capaz de julgá-los". ${ }^{96}$

Com 0 mesmo argumento 0 artigo "Querido Sr. Urbanista”, em Habitat n 12 (1953), comenta 0 crescimento vertiginoso da cidade de São Paulo que, próxima a completar quatrocentos anos, havia se transformado em uma das cidades mais feias do mundo devido a falta de leis urbanísticas. 0 texto e as imagens que 0 acompanham denunciam o caos resultante da falta de planejamento da cidade e configuram uma espécie de "carta de apelo" aos urbanistas, clamando por uma ação a fim de deter os interesses econômicos que "constroem arranhacéus horrorosos" e que abandonam a população sem saneamento básico.

"Continue assim, senhor Urbanista, que ergueremos, em sua homenagem um monumento de gratidão". ${ }^{97}$

No entanto, apesar de a revista realizar a denúncia dessas questões, apenas uma vez publica um enfrentamento projetual direto a elas. "Projeto para favela", em Habitat n 13 (1953), divulga o projeto de final de curso do ainda estudante Wit-Olaf Prochinik ${ }^{98}$, 0 qual busca enfrentar o problema da ocupação desenfreada dos morros cariocas e a questão da moradia popular. É curioso notar que esse projeto tem como objeto a cidade do Rio de Janeiro e não a de São Paulo. Seria uma forma de dizer que esses problemas são universais e que suas soluções também o seriam? Afinal, neste momento São Paulo já contava com exemplos de arquiteturas realizadas como instrumento de ação contra o déficit habitaciona 99 .

Há também dois momentos em que a revista publica projetos que se destacam pela escala urbana e que incorporam os princípios da urbanística moderna. São eles a urbanização da Praia de Pernambuco no Guarujá e o Plano de ocupação para a Universidade Federal do Rio de Janeiro.

0 artigo "Plano de urbanização da praia de Pernambuco, Guarujá", em Habitat n 14 (1954), tem apresentação de Geraldo Ferraz, que aborda a ocupação desordenada do litoral brasileiro como conseqüência do crescimento econômico e facilidade de deslocamento, tornados possíveis a partir da expansão das rodovias que aproximaram as distâncias. Ferraz introduz o projeto do arquiteto Henrique Mindlin, apresentado simultaneamente nas páginas

\footnotetext{
${ }^{96}$ SOUZA, Abelardo. "Planos", Habitat, n02, jan./ mar. 1951, p. 15.

97 "Querido Sr. Urbanista”, Habitat, São Paulo, n 12, set./ nov. 1953, p. 2.

${ }^{98} 0$ nome deste arquiteto, ainda estudante, integra a lista dos projetos recusados pela comissão organizadora da $1^{\mathrm{a}} \mathrm{e}$ da $4^{\mathrm{a}} \mathrm{EIA}$.

${ }^{99}$ Podemos destacar após a Revolução de 30 em São Paulo a produção dos IAPs (Instituto de Aposentadoria e Pensão) no que tange a questão habitacional, uma produção de qualidade técnica realizada dentro de órgãos públicos e pouco conhecida pela historiografia oficial. Sobre 0 assunto, ver BONDUKI, Nabil. Origens da habitação social no Brasil, São Paulo: Estação Liberdade / Fapesp, 1998.
} 

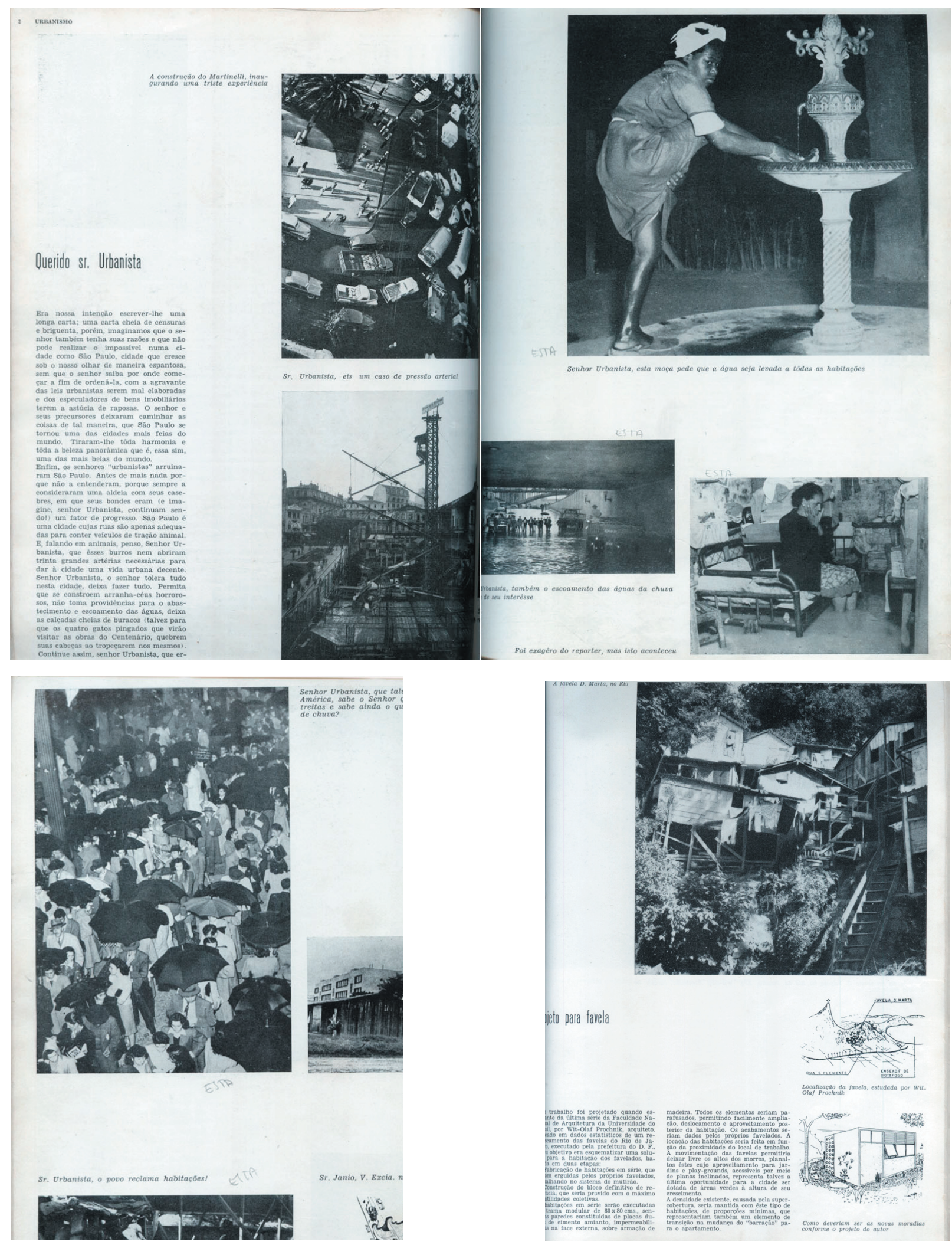

80 e 81 . "Querido Sr. Urbanista" convoca os profissionais e clama por regulamentação urbanística para subverter 0 quadro que fez de São Paulo "uma das cidade mais feias do mundo".

82. "Projeto para favela" é o único momento que Habitat publica um projeto para solucionar o déficit habitacional. 
de Habitat e no IV Congresso Brasileiro de Arquitetos ${ }^{100}$, exaltando-0 como um exemplo em que a técnica figura como fator humano de transformação da natureza:

“(...) Tem-se condenado a técnica em uma função destruidora da região, da sua configuração, do seu caráter. No entanto a grande tarefa da técnica é a de afeiçoar a terra às novas necessidades do homem e não a contrariar nos seus desígnios estabelecidos. Importa sim que haja na cultura e na prática da técnica, principalmente do urbanismo, no planejamento, essa elasticidade que agora nos fala o mestre Alvar Aalto, a dutilidade ativa que não elimine, mas exalte as condições naturais da região trabalhada. Seria 0 fim das nossas possibilidades como homens da idade da técnica se esta devesse empobrecer um ambiente em lugar de lhe acrescentar novos incentivos, novos estímulos vivos de serenidade, de alegria (...)". ${ }^{101}$

Segue ao texto de Ferraz uma extensa apresentação do projeto que observa suas qualidades urbanísticas que trata o emaranhado sistema com ciência e arte; chama a atenção ainda para a separação entre os pedestres e 0 automóvel, já recomendada pelos CIMs. Além do plano urbanístico, são divulgados os projetos para as diversas escalas que o constituem: as sedes do cubes, o hotel e as diversas tipologias de habitação, desde

${ }^{100}$ Como uma das atividades programadas do evento descrita nos anais do IV Congresso, na excursão dos congressistas ao Guarujá o projeto do loteamento da Praia de Pernambuco foi exposto pelo arquiteto Henrique Mindlin ampla e detalhadamente. O IV Congresso Brasileiro de Arquitetos ocorreu paralelo às comemorações do IV Centenário de São Paulo, da II Bienal de Artes e da $2^{\mathrm{a}}$ EIA.

101 "Plano de urbanização da praia de Pernambuco, Guarujá", Habitat, São Paulo, n 14, jan./fev. 1954, p. 11.
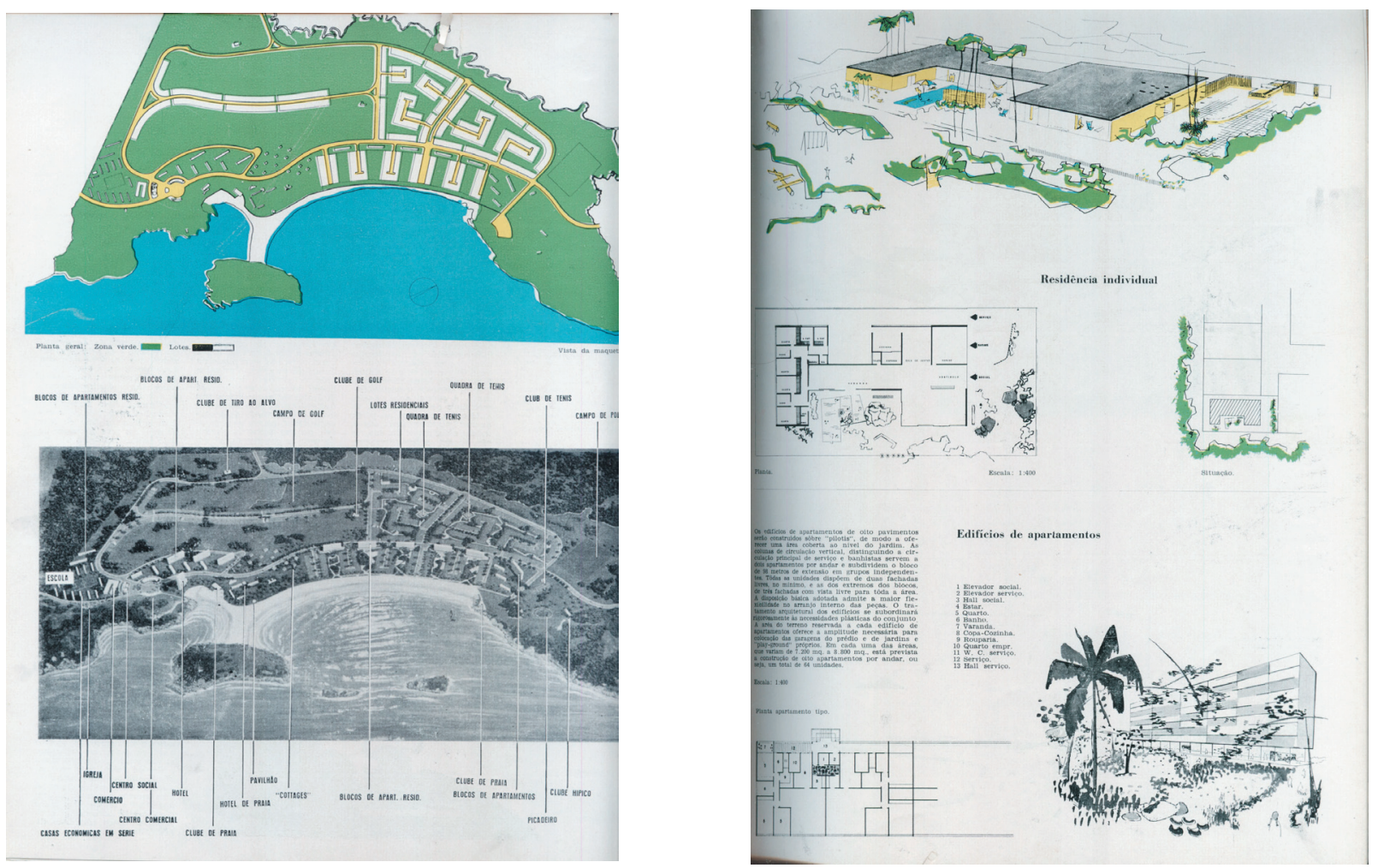

83 e 84 . Geraldo Ferraz em "Urbanização na praia de Pernambuco", apresenta o projeto do arquiteto Henrique Mindlin que contempla as mais diversas escalas as recomendações dadas pelos CIAMs. 
residências individuais até edifícios de oito pavimentos elevados sobre pilotis. Acompanham os projetos, pequenos textos que destacam elementos que caracterizam 0 caráter moderno da arquitetura em questão: 0 claro zoneamento do empreendimento, a racionalidade nas construções, estrutura independente da vedação com plantas flexíveis, o solo permeável, equipamentos coletivos etc.

A divulgação do projeto para a Cidade Universitária do Rio de Janeiro ${ }^{102}$ ocupa as primeiras trinta páginas da edição de $n^{0} 15$ de Habitat (março/abril 1954), caracterizando esta como uma edição especial ao projeto que teve no desenvolvimento de seu primeiro anteprojeto a consultoria de Le Corbusier ${ }^{103}$, realizada no mesmo período em que 0 arquiteto franco-suíço vem para o Brasil a convite do governo para realizar um conjunto de conferências sobre os problemas da arquitetura e do urbanismo modernos e "opinar" no projeto do MES.

0 projeto apresentado na revista seria a proposta definitiva realizada por um grupo coordenado pelo arquiteto Jorge Machado Moreira, também membro da equipe que elabora o projeto do Ministério (MESP), em 1936.

Dentre os artigos que integram o "especial", "Cidade Universitária do Rio de Janeiro", escrito pelo coordenador do projeto, 0 arquiteto Jorge Machado Moreira procura conceituar a idéia de campus universitário. 0 autor caracteriza a centralização das escolas, faculdades e institutos como a possibilidade da interdependência e da interpenetração das ciências, bem como a geração de vantagens econômicas pela otimização dos edifícios e laboratórios. Coloca ainda a necessidade de um projeto flexível, que absorva as transformações ao longo da vida da universidade. Segue os artigos "Universitas" que traz um histórico das comunidades de ensino e pesquisa ao longo dos séculos e "Índices universitários", de Luiz H. de B. Horta Barbosa, o qual analisa diversos índices relativos à educação: alfabetização, formação primária, formação superior, número de bibliotecas e vagas nas universidades. 0 autor ainda aponta a correlação entre o progresso econômico, a instrução da população e 0 preparo intelectual.

Segue a estes uma série de fotografias das obras, a descrição do projeto e a publicação da implantação geral do conjunto. 0 artigo também divulga o projeto dos primeiros edifícios a serem executados, todos acompanhados

\footnotetext{
102 Foram encontrados nos arquivos do Instituto Lina Bo e Pietro Maria Bardi correspondências de Lina endereçadas ao arquiteto Jorge Moreira e ao Sr. Renato Lima, solicitando material para a divulgação do material para a publicação do próximo número de Habitat. Curioso notar que as correspondências são datadas em 3 de março de 1954, e solicitam 0 material para 0 dia $1^{0}$ do mesmo mês, sendo que 0 mês de veiculação do $\mathrm{n}^{0} 15$ de Habitat aparece como março/abril e traz em metade de suas páginas esse material.

${ }^{103}$ Para o mesmo projeto foi chamado também o arquiteto italiano Piacentini, com o qual o ministro Gustavo Capanema também mantinha um "certo" compromisso estabelecido pelo "quadro do'namoro' velado existente entre o fascismo e o getulismo". Sobre estes acontecimentos, ver SANTOS, Cecília Rodrigues dos et al., Le Corbusier e o Brasil, São Paulo: Tessela/Projeto, 1987, p. 110.
} 

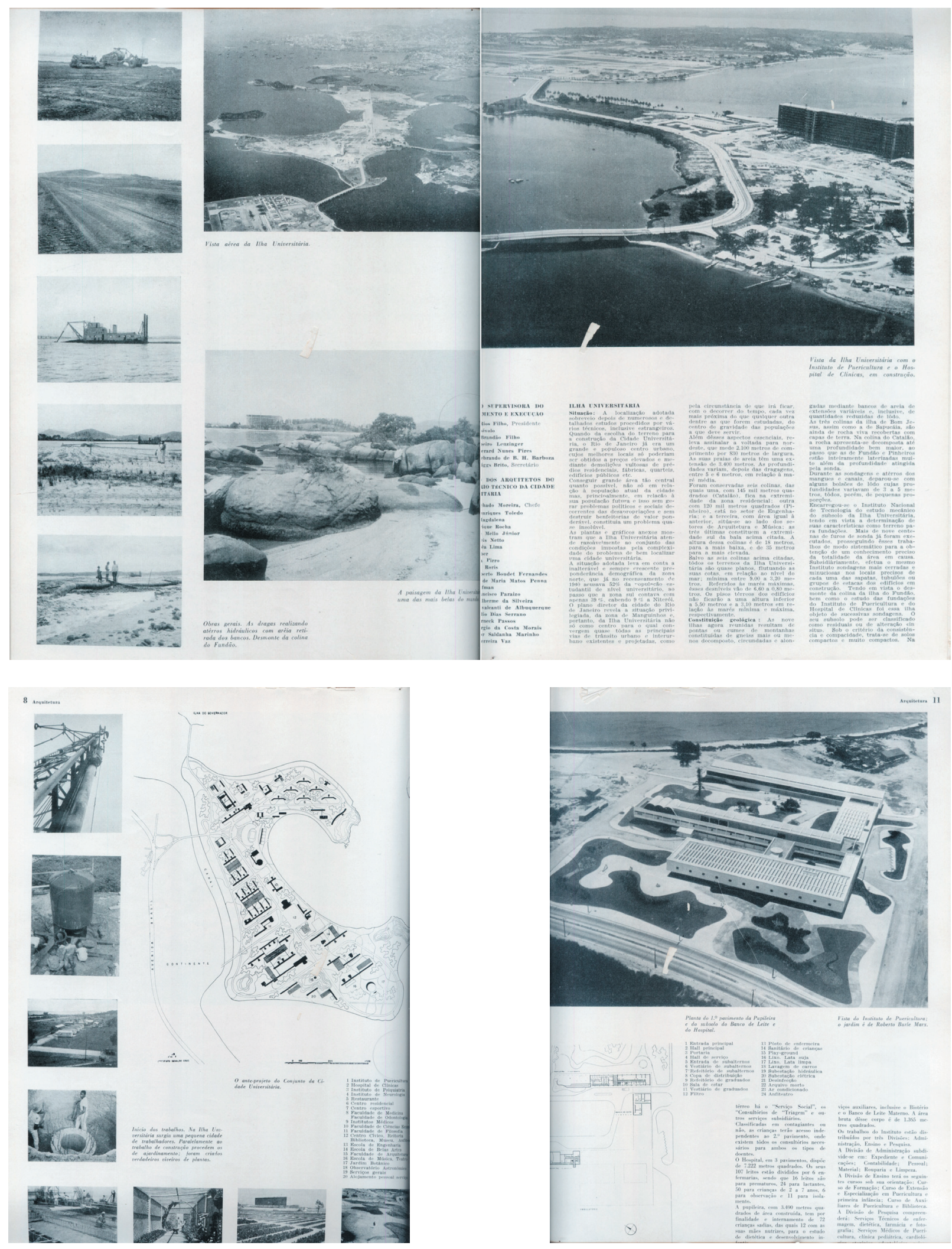

85 a 87 . "Cidade Universitária no Rio de Janeiro" dedica um extenso artigo, que toma grande parte da décima quinta edição de Habitat, sem no entanto revelar uma só palavra da polemica em que o projeto esteve envolvido durante seu desenvolvimento. 
de um cuidadoso texto descritivo e completo material gráfico, entre os quais podemos destacar o Instituto de Puericultura que acabara de receber o Prêmio para Hospitais na $2^{\mathrm{a}}$ EIA e a Faculdade Nacional de Arquitetura, que seria laureada na $4^{\mathrm{a}} \mathrm{EIA}$.

Ainda sobre planejamento, mas desta vez territorial, a expansão da rede rodoviária é apresentada pela revista como conseqüência do desenvolvimento econômico, crescimento populacional e implantação da indústria automobilística no Brasil. Com esta "ordenação do território" nota-se 0 aparecimento de novas preocupações, como as descritas no artigo "Arborização e paisagismo nas estradas de rodagem", em Habitat n 8 (1952). Nele, Victor Canongia Barbosa, do Departamento Nacional de Estradas e Rodagem, discorre por meio de experiências internacionais sobre a necessidade de outras obras que deveriam acompanhar a abertura das estradas: o paisagismo dos trechos laterais para proteção e embelezamento, bebedouros, mirantes e pavilhões. Desta forma atribui aos elementos infraestruturais questões além das simplesmente funcionais, apontando seu potencial ativo na construção de um território com qualidades além da eficiência.

Podemos ver também no projeto para a nova sede dos Diários Associados uma abordagem urbanística bastante característica do moderno. 0 projeto, divulgado no artigo "Taba Guaianases", publicado em Habitat n 14 (1954), apresenta uma superestrutura em concreto armado projetada por Lina Bo e Pier Luigi Nervi. 0 projeto representa o ideário moderno ao propor um edifício autônomo que reúne em uma única estrutura programas diversos, como habitação, auditório para 5 mil pessoas, dois teatros de 1.500 lugares, além da sede dos estúdios de rádio e televisão dos Diários Associados. 0 autor utiliza-se também desse projeto como pretexto para expor idéias a respeito da estandardização das unidades habitacionais: a solução aponta as qualidades e diversidades possíveis nas 1.500 unidades padronizadas e organizadas a partir de apenas duas tipologias.

É possível notar ainda a repetição de "assuntos" ou "programas de uso" ao longo do período estudado, os quais caracterizam o momento histórico que a revista registra em suas páginas, como a reincidência de artigos dedicados à publicação de projetos de edifícios verticais e de equipamentos públicos, que retratam 0 crescimento urbano vertiginoso que a cidade sofria naquela década.

Marcando o processo de verticalização e adensamento da região central da cidade de São Paulo, destacamos os projetos para os edifícios que "inauguram" o uso misto, tão característico da arquitetura moderna. São exemplares por unir habitação, comércio e ou serviço, três projetos de Gian Carlo Palanti, um publicado em Habitat n 3 (1951) "Edifício em São Paulo"; outro em Habitat n 6 (1952) "Edifício em Santos" em co-autoria 

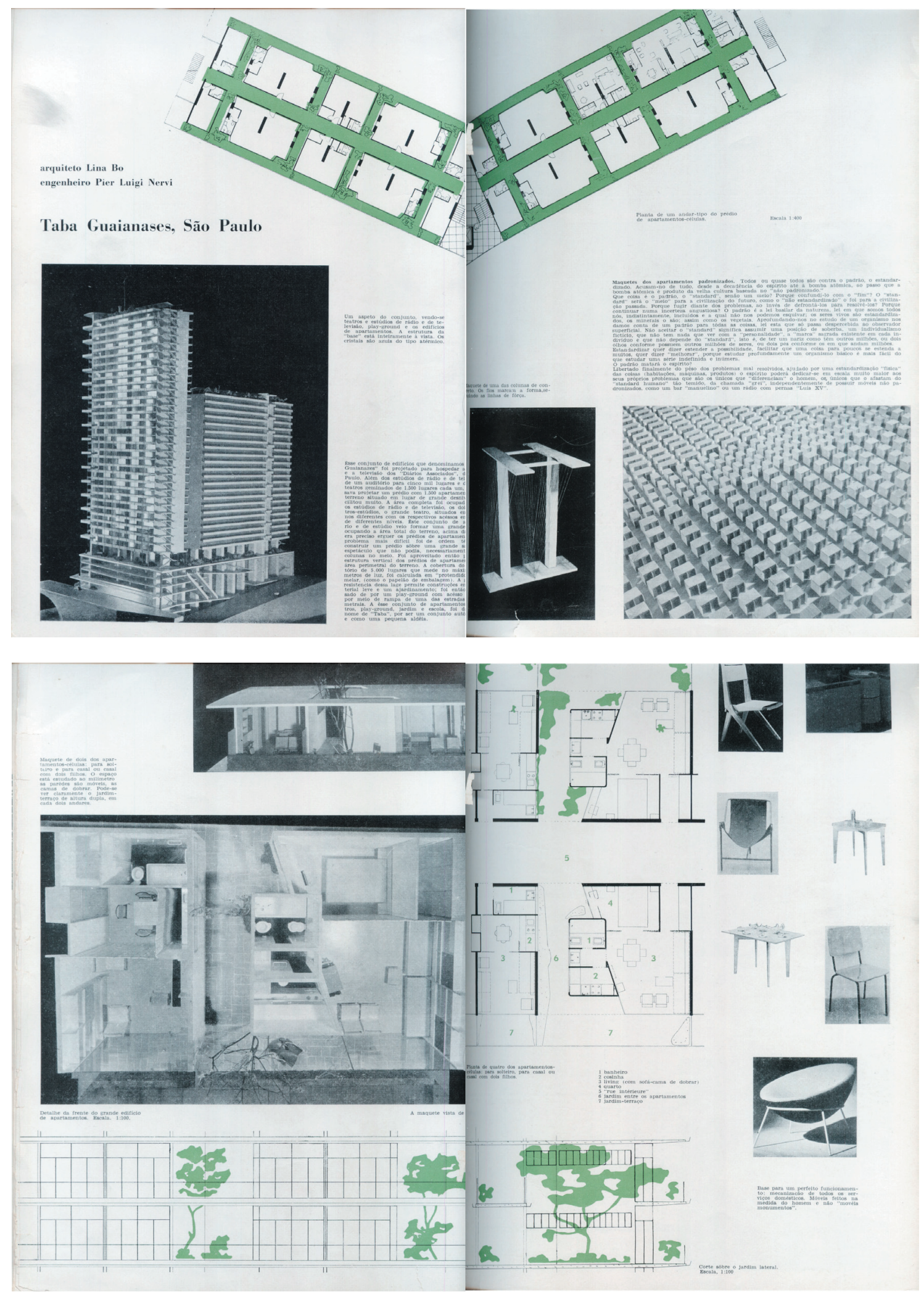

88 e 89 . Em "Taba Guaianases", vemos uma preocupação com todas as escalas do projeto: desde a superestrutura, as unidades habitacionais, chegando até a sua ocupação, com sugestão de layout e mobiliário compatível com a arquitetura proposta. 
com Alfredo Mathias e, por último, em Habitat n 10 (1953) "Prédio de apartamentos em São Paulo"; ainda dois projetos de Abelardo de Souza localizados na Avenida Paulista: "Prédio de apartamentos em São Paulo" em Habitat n 7 (1952) e "Prédio Nações Unidas" em Habitat n 12 (1953). Em "Edifício Vila Normanda", Habitat n 13 (1953), mais um projeto na área central de autoria de Antonio José Capote Valente e incorporação da Companhia Paulista de Investimentos.

Nesses projetos podemos destacar o somatório de elementos regionais ao vocabulário internacional, além de, como no caso do edifício Nações Unidas, algumas transformações dos padrões urbanísticos vigentes, como a alta densidade populacional e uma destacada integração entre áreas públicas e privadas, realizada através das galerias comerciais que marcam neste momento as construções da região central da cidade e que passam a ocupar o térreo dos edifícios, tornando o lote privado permeável a cidade.

É possível notar entre os profissionais, cuja produção Habitat divulga, a presença de um grupo que se altera ao longo dos primeiros quinze números. Dos arquitetos que terão suas obras publicadas uma grande maioria tem ligação com as entidades de classe, como o Instituto dos Arquitetos do Brasil, ou participam de grupos que os caracterizam, como os do "Convênio Escolar".

Também é possível destacar as reincidências ou "coincidências" entre os nomes e os projetos publicados em Habitat e os que terão suas obras expostas e premiadas pelo júri nas primeiras Exposições Internacionais de Arquitetura, a primeira realizada em 1951 e a segunda em 1953/1954. Nestes casos Habitat quase sempre antecede a divulgação e o reconhecimento do arquiteto ou obra, e revela a "afinidade" existente entre essas instituições, as quais, juntas, colaboraram para a institucionalização do moderno pela eleição comum de uma produção que qualificam como uma arquitetura imbuída de comprometimento social.

Indicando a recorrência destes nomes comprometidos em sua produção com a arquitetura moderna, é possível verificar Eduardo Corona com participação na $2^{\mathrm{a}}$ EIA com um projeto de Grupo Escolar e Parque Infantil. Também Ernst Roberto Mange, Hélio Duarte, Oswaldo Correa Gonçalves e Roberto Tibau participam com edifícios residenciais, industriais e comerciais na $1^{\text {a }}$ EIA. Vale também destacar os nomes de Corona e Oswaldo Correa Gonçalves nos quadros diretivos do IAB/SP.

Trazendo residências, mas como parte de um conjunto de artigos em Habitat $n^{\circ} 10$ (1953) que apresenta 0 desenvolvimento de um novo loteamento do Morumbi, os artigos "Residência no Morumbi" e "Outra residência no Morumbi" publicam projetos que caracterizam a boa arquitetura no novo empreendimento, respectivamente 


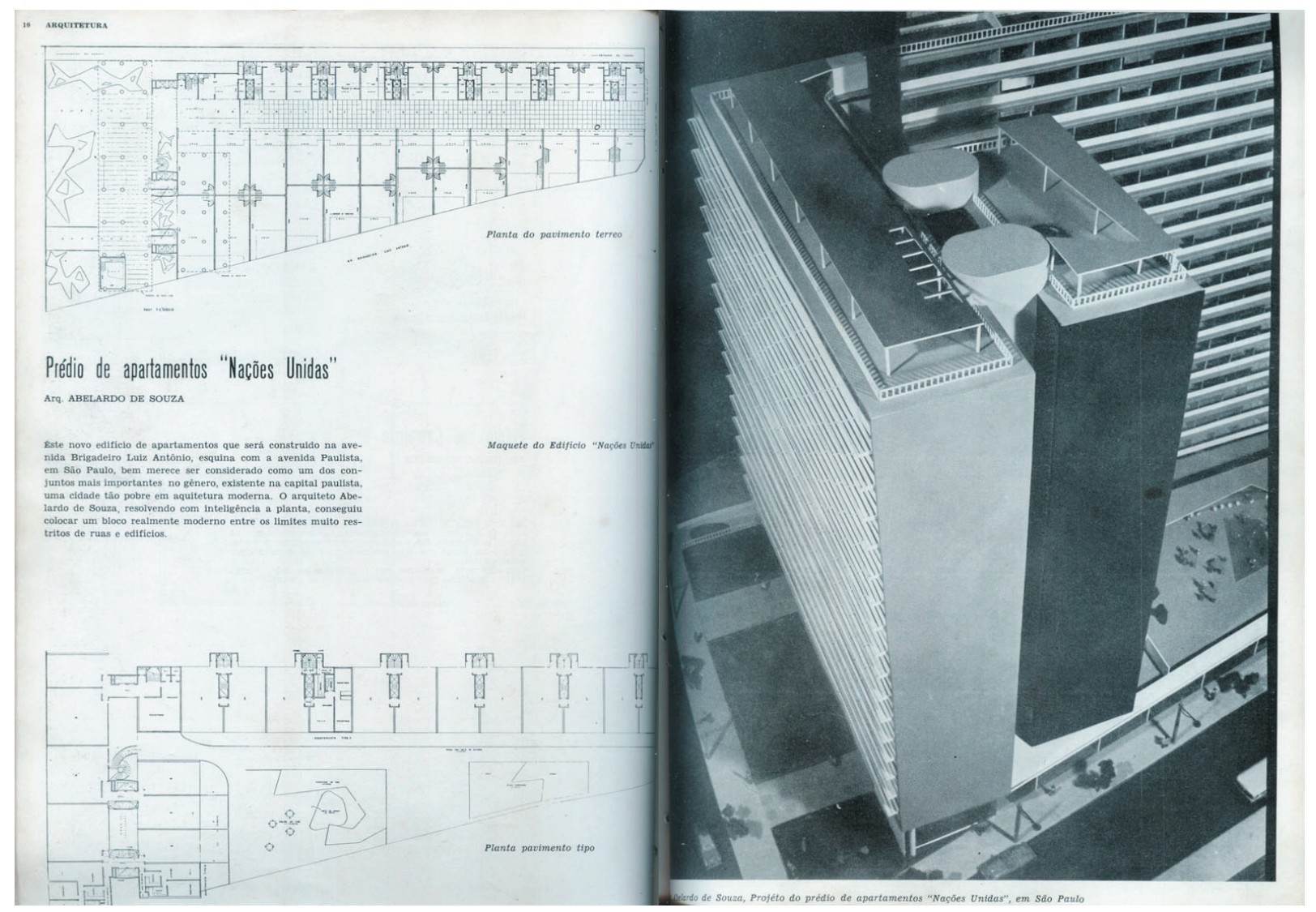

90 . 0 projeto de Abelardo de Souza para o conjunto residencial e comercial na Avenida Paulista é publicado com grande destaque no artigo "Prédio 'Nações Unidas'”, projeto que representa a alteração do cenário que a cidade de São Paulo apresenta no início dos anos 50.

de Lina Bo e Oswaldo Bratke ${ }^{104}$.

Afinada aos princípios de uma função social, a produção de arquitetura e design de Lina Bo e seus colaboradores, entre eles Giancarlo Palanti, têm espaço garantido na revista. Logo no primeiro número, o projeto para a sede do Museu de Arte de São Paulo, inaugura uma série de outros artigos que registrarão a produção de Lina naqueles primeiros anos de Brasil, entre eles sua residência no Morumbi e o projeto para o Museu de São Vicente, em "Museu a beira do oceano", Habitat n 8 (1952).

Na divulgação do projeto para o museu em São Vicente, Lina destaca a importância do sentido educativo da arquitetura que deve estar coesa com o projeto museográfico que irá abrigar; seguindo assim a mesma direção colocada para o MASP no primeiro número de Habitat, que, como comentado, o próprio texto não distingue a apresentação do projeto do edifício e do museu moderno que ali implantavam.

A residência de Lina aparece, como já apontado, por duas vezes na revista. A primeira, na edição $\mathrm{n}^{0} 10$ (janeiro/ março 1953), em que o texto da própria autora é acompanhado de um farto material que apresenta a residência 
como exemplo da boa arquitetura que estava se realizando no novo bairro do Morumbi. E no segundo momento, em Habitat $\mathrm{n}^{0} 12$ (julho/setembro de 1953), como argumento do artigo publicado na revista Interiors.

A interlocução realizada em Habitat entre personalidades locais e a crítica internacional colabora na construção e amadurecimento da arquitetura moderna brasileira. A revista apresenta um quadro de colaboradores, em sua maioria arquitetos e estudiosos das artes, que assume a reflexão crítica até mesmo da própria produção, conseqüência da já comentada escassez de crítica especializada.

Em Habitat n 5 (1951) os artigos "Da necessidade de crítica sobre arquitetura", de Eduardo Corona, e "A arte menos estudada", de Giusta Nicco Fasola, alertam para a importância da crítica para que possa haver uma sociedade apta a julgar a sua própria produção. 0 primeiro artigo aborda o papel dos críticos de arte e a sua função social que "contribui de maneira decisiva para o desenvolvimento da cultura e divulgação das leis que regem a sociedade, a vida do homem e sua natureza, e a correspondente manifestação artística"105. A ausência da crítica de arquitetura seria, segundo Corona, conseqüência da visão utilitarista dedicada a essa arte e atribui ao crítico despertar o público para a compreensão da arquitetura, missão esta mencionada no $1^{\circ} \mathrm{CIAM}$ (1928),

${ }^{104}$ A residência de Bratke, membro da Comissão artística da $2^{a}$ EIA, só é publicada em Habitat quase dois anos após ter sido merecedora de Menção Honrosa na 1ª EIA.

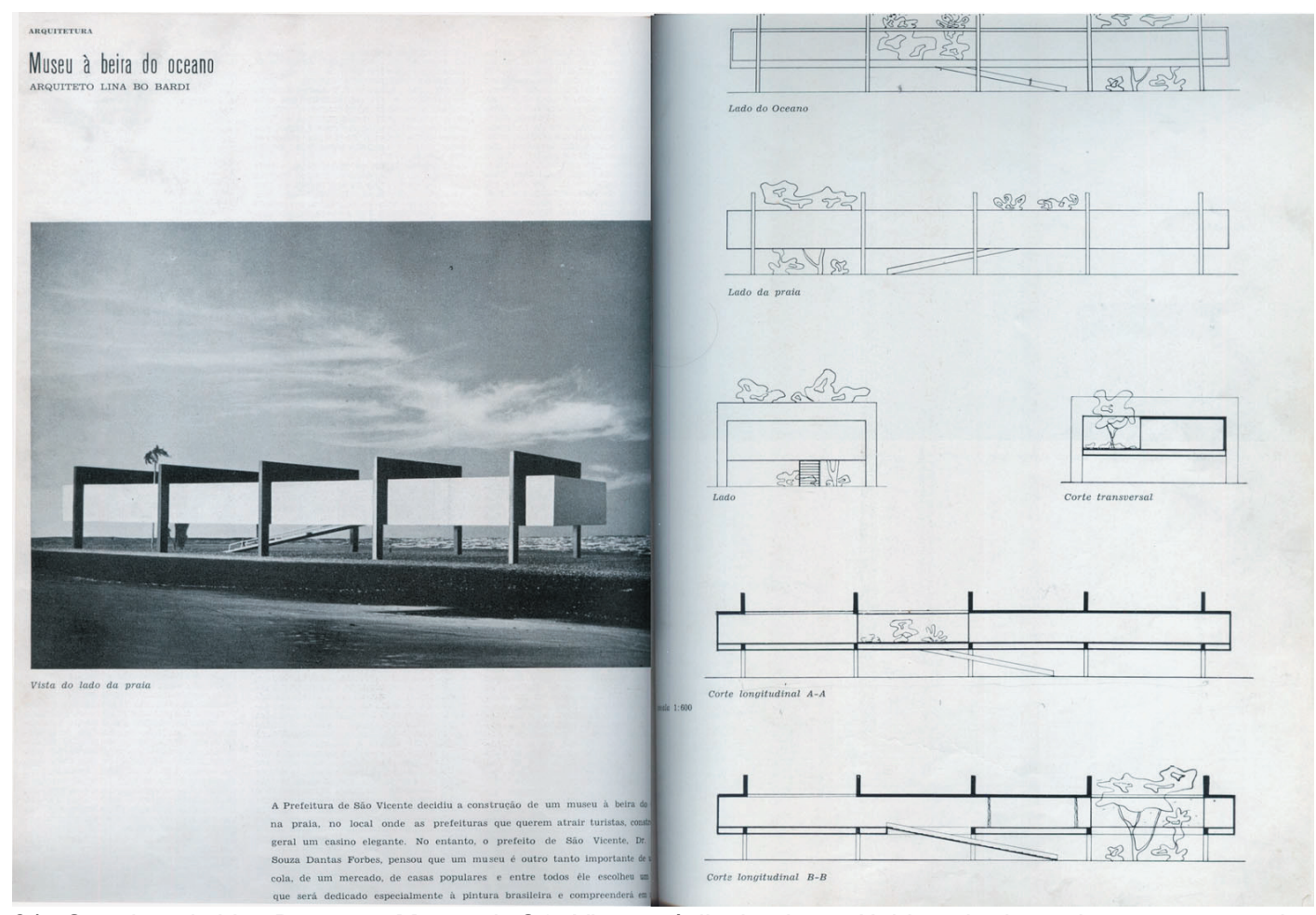

91 . 0 projeto de Lina Bo para o Museu de São Vicente é divulgado em Habitat obedecendo os mesmos princípios do MASP, a preocupação em integrar o projeto arquitetônico e o projeto museográfico, desta vez somado a paisagem existente. 
que instituiu ao arquiteto o papel social de agente divulgador da arquitetura Moderna.

0 segundo artigo atribui à má arquitetura a incompreensão e o desconhecimento relacionados a esta disciplina: “(...) a fim de conseguir uma boa arquitetura não bastam bons arquitetos; é necessário que eles tenham a possibilidade de executar sua obra, isto é, de encontrar acordo e confiança dos comitentes, do público que apóia ou critica, precisando eles por isso do julgamento contínuo dos outros"106. Neste sentido Abelardo também chama a atenção para risco existente na forma como a arquitetura é vista pelos homens "médios". No desejo de sobrepujar e na utilização do dinheiro a arquitetura é desvirtuada e assim a casa não reflete mais a vida, mas sim um conjunto de preconceitos, de aparências e de convenções; a arquitetura burguesa torna-se também a direta responsável pela insuficiência moral do homem contemporâneo.

Com mesmo argumento e título semelhante "Necessidade da crítica de arquitetura", em Habitat n 7 (1952), acrescenta a dificuldade em exercer uma crítica não pautada em elogios à base de superlativos como os lidos nos informes, provavelmente escritos pelos próprios empresários.

"Falar de arquitetura subentende-se conhecer a arte da construção, as novidades, a história, os materiais e tudo quanto mais necessário se faz para emitir uma opinião". ${ }^{107}$

Como exemplo de uma crítica embasada, Pietro Maria Bardi transforma-se no crítico oficial da produção nacional para o estrangeiro. No artigo "O Arquiteto de Jardins, Roberto Burle Marx”, em Habitat n 15 (1954), a revista reproduz o prefácio do catálogo da exposição de Burle Marx organizada pelo MASP e que seria sediada no Smithsonian Institution. No texto Bardi faz um breve histórico profissional do arquiteto-paisagista e chama a atenção para o caráter abstrato e surrealista de seus jardins.

Por intermédio de Bardi, seu grande admirador, outras vezes a revista abre espaço a Burle Marx, como no artigo "Os jardins de Burle Marx”, em Habitat n 3 (1951). Neste, sua obra paisagística e artística é exaltada por Bardi como um dos mais importantes patrimônios da história da arte brasileira, que sugere a inclusão da escultura em seus jardins e faz a crítica aos painéis de azulejo, ao que chama de anti-historico e anti-nacionalista, mesmo antes de Max Bill os ter contestado. Destaca o conhecimento botânico, histórico e geográfico do paisagista que "Ihe permite desenhar essas suas arquiteturas plásticas da natureza". 0 artigo inclui além de imagens dos jardins e dos projetos de Burle Marx, gravuras do livro "Histoire des jardins anciens et modernes" e o texto de Arthur Maugin de 1887, caracterizando os jardins antigos e os relacionando com o moderno. Novamente

105 "Da necessidade de crítica sobre arquitetura", Habitat, São Paulo, nº 5, out./dez. 1951, p. 46.

106 "A arte menos estudada", Habitat, São Paulo, n 5, out./dez. 1951, p. 47. 
vemos neste a aproximação dos tempos, tão cara a Bardi.

0 MASP já havia dedicado uma mostra individual ao artista-paisagista-arquiteto, que Habitat $\mathrm{n}^{\circ} 8$ (1952) divulga em "Uma exposição de Burle Marx". A revista colabora ainda para a consagração de Burle Marx ao publicar incontáveis projetos de arquitetura que possuem sua colaboração, como a residência Walther Moreira Sales cujo projeto paisagístico é laureado na $2^{\mathrm{a}}$ EIA.

Burle Marx tem também sua obra consagrada nas Bienais paulistas dos anos 50, nas quais recebeu um grande número de prêmios. As novas características de seu trabalho, fruto de uma pesquisa projetual com utilização de espécies da flora brasileira, inaugura um paisagismo com características nacionais, desvinculado de escolas ou preceitos estrangeiros, que lhe garante o lugar de expoente diante da crítica internacional.

Ainda entre os poucos exemplares da produção carioca publicada em Habitat, Olavo Redig, tem o projeto para Sr. Walther Moreira Sales ${ }^{108}$ publicado em "Uma casa no Rio de Janeiro", Habitat n 6 (1952). Apresentada por meio de peças gráficas, imagens da obra e um texto sem autoria que discorre sobre a constituição da arquitetura moderna brasileira, o artigo utiliza a oportunidade de apresentar o projeto para proclamar os avanços do racionalismo trazido por Le Corbusier até a liberdade plástica e formal representada exemplarmente no projeto exposto.

Outro carioca, Sérgio Bernardes, figura com projetos residenciais ${ }^{109}$. Apresentados por Oswaldo Correa Gonçalves, "Arquitetura de Sérgio Bernardes", em Habitat n 7 (abril/junh01952), chama a atenção para as características especulativas da obra e o compromisso social que a caracteriza. A obra de Bernardes, um ano depois de ter sido publicada em Habitat, recebeu o prêmio na $2^{\text {a }}$ EIA (dezembro de 1954), na categoria Jovem Arquiteto Brasileiro. 0 júri manifesta-se em relação a residência Maria Carlota Macedo Soares pelo qual é premiado, incentivando o arquiteto a "seguir nessa via de simplicidade e abordagem direta do problema que melhor responde à arquitetura das habitações". Desta forma manifesta-se em posição crítica a outro caminho, o que poderia levar a um perigoso formalismo.

Vale destacar ainda que, paralelo a II Bienal, por ocasião das comemorações do IV Centenário de São Paulo,

\footnotetext{
107 "Necessidade da crítica sobre arquitetura", Habitat, São Paulo, no 7, abr./jun. 1952, p. 53.

${ }^{108}$ Residência com a qual Burle Marx é ganhador de prêmio na $2^{a}$ EIA pela Categoria 12 - Problemas Viários, com projeto paisagístico.

${ }^{109}$ Neste artigo são apresentados três projetos de Sérgio Bernardes, com os quais procura exemplificar as características e preocupações presentes na produção de arquitetura moderna brasileira.
} 

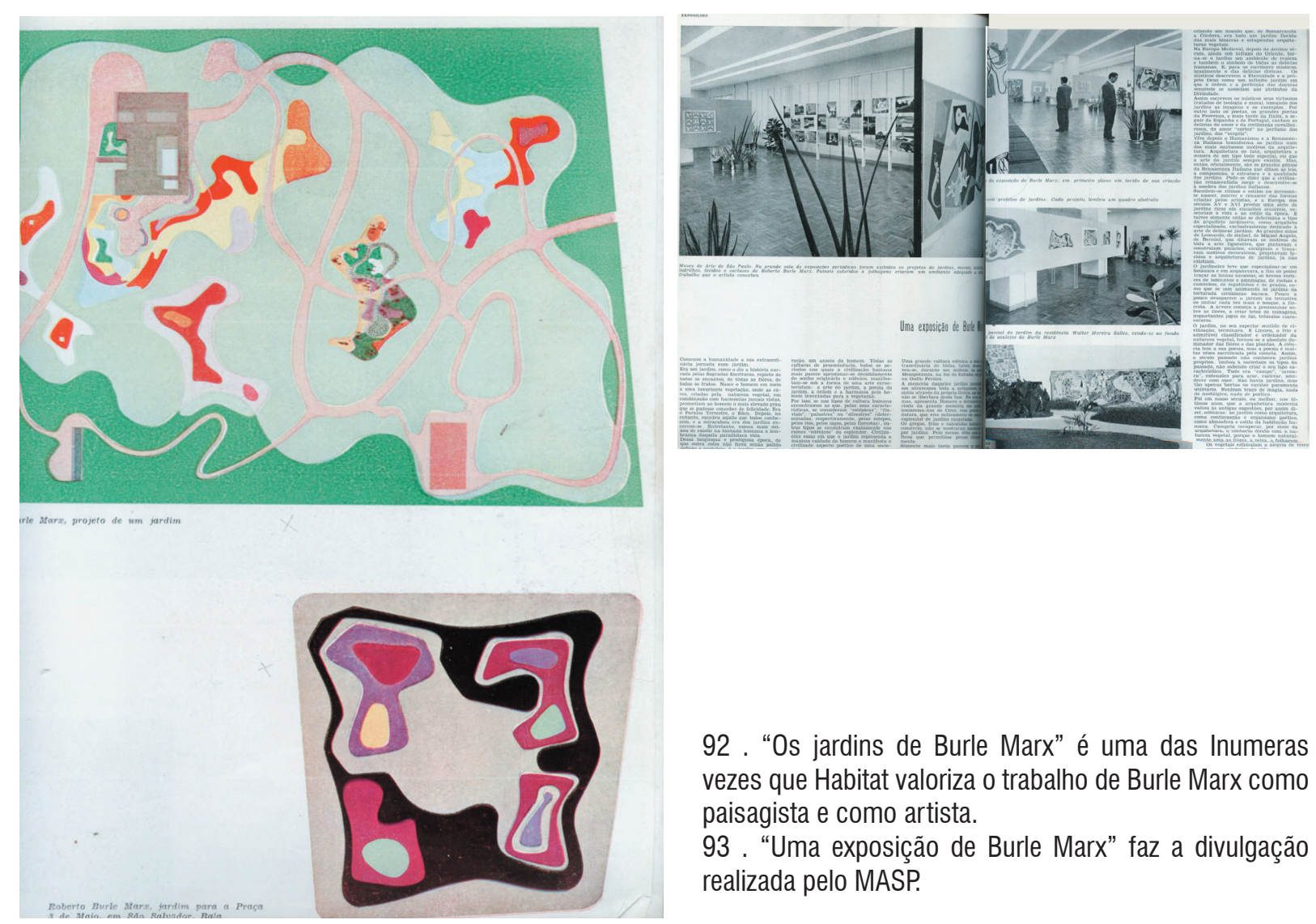

92. "Os jardins de Burle Marx" é uma das Inumeras vezes que Habitat valoriza o trabalho de Burle Marx como paisagista e como artista.

93 . "Uma exposição de Burle Marx" faz a divulgação realizada pelo MASP.

Sérgio Bernardes realizou o projeto encomendado pela Companhia Siderúrgica Nacional para uma mostra temporária no Parque do Ibirapuera; um pavilhão com elegante estrutura em aço construído como ponte sobre 0 córrego do parque.

Também Oscar Niemayer e Affonso Reidy aparecem como rara exceção a "escolha" editorial que circunscreve a produção de arquitetura moderna em São Paulo. Como descrito anteriormente, as diferenças e divisões possíveis da produção de arquitetura dos dois grandes centros brasileiros explicariam Niemeyer aparecer com apenas três projetos, dois em São Paulo e um em Campinas. Reidy apenas com o Colégio Paraguai-Brasil em Assunção, apesar de seu projeto para o Conjunto Residencial de Pedregulho ter obtido o prêmio na Categoria Projeto de Organização de Grandes Áreas na $1^{\mathrm{a}}$ EIA e de participar como membro do Júri de Premiação do $2^{\circ}$ EIA.

0 numero restrito de projetos de Oscar Niemeyer publicado em Habitat contrariam a forte atuação que 0 arquiteto tem na capital paulista, onde neste momento destacam-se os projetos para o Parque do Ibirapuera, 0 Edifício Califórnia, o Edifício Triângulo, o Edifício Eiffell e o Edifício Copan, que o levaram a manter um escritório em São Paulo coordenado por Carlos Lemos; e mesmo a relação de proximidade com os arquitetos ligados a 
revista, principalmente Eduardo Corona e Abelardo de Souza.

0 artigo "Duas construções de Oscar Niemeyer", em Habitat n 2 (janeiro/março 1951), publica o projeto para a Fábrica Duchen, apresentado na revista apenas como Conjunto Industrial, que caracteriza a já referida renovação no quadro das atividades industriais na capital paulista; e o projeto de um Edifício para Escritórios, destinado para escritórios e comércio, Iocalizado a Rua Barão de Itapetininga. 0 projeto divulgado trata do Edifício Califórnia, o já citado edifício em construção que Max Bill iria visitar em 1953, alvo das críticas realizadas durante a palestra proferida no auditório da FAU, pelo qual exemplifica as incoerências da arquitetura moderna brasileira.

0 texto de Lina Bo, paralelo ao início do debate com a crítica internacional, acompanha os desenhos dos projetos e as imagens das maquetes e faz um breve histórico da utilização do concreto e de suas possibilidades plásticas, as mesmas que anos depois seriam questionadas por Max Bill:

\begin{abstract}
"sentidas instintivamente por Oscar Niemeyer, que se afasta sempre mais da estrutura da 'gaiola', em sua busca de uma plástica que não é a barroca, porque o barroco em arquitetura é ainda uma expressão completamente estética do artesanato e enquanto na procura de formas livres, a arquitetura moderna se preocupa com 0 homem, e na expressão plásticas dessas formas livres há a procura da perfeição da máquina.

Permanece o problema da arbitrariedade: uma forma livre é arbitrária quando julgada no âmbito das formas geométricas definidas, mas não é mais arbitraria se projetada na possibilidade infinita das formas livres; resta julgar se aquela forma representa a liberdade infinita do ato da criação do artista, resta julgar se aquela forma atinge ou não a arte(...)". ${ }^{110}$
\end{abstract}

Em contraponto a liberdade formal de Niemeyer e a exemplo da racionalidade na arquitetura, "Arquitetura industrial", em Habitat n 10 (1953) divulga a fábrica da "Arno" de Rino Levi, que aparece como originária da racionalização atribuída às experiências anteriores de Bherens e dos alemães.

É curioso notar que no artigo "Prédio em Campinas", que traz também um projeto de Niemeyer, diferente do primeiro, não há nenhum texto que esclarece a obra ou venha a tecer algum comentário; o que indica que nem sempre o reconhecimento ou o valor da arquitetura publicada é determinante para a definição do formato ou conteúdo da matéria. Esse artigo, publicado em Habitat n 12 (1953), não pode contar com Lina e Bardi, ausentes do Brasil, que possivelmente seriam os mais indicados para exercer uma crítica capacitada ao valor do arquiteto e da obra em questão.

Há também em Habitat grande espaço para os arquitetos de formação carioca que se fixaram em São Paulo,

110 "Duas construções de Oscar Niemeyer”, Habitat, São Paulo, n 2, jan./mar. 1951, p. 6. 

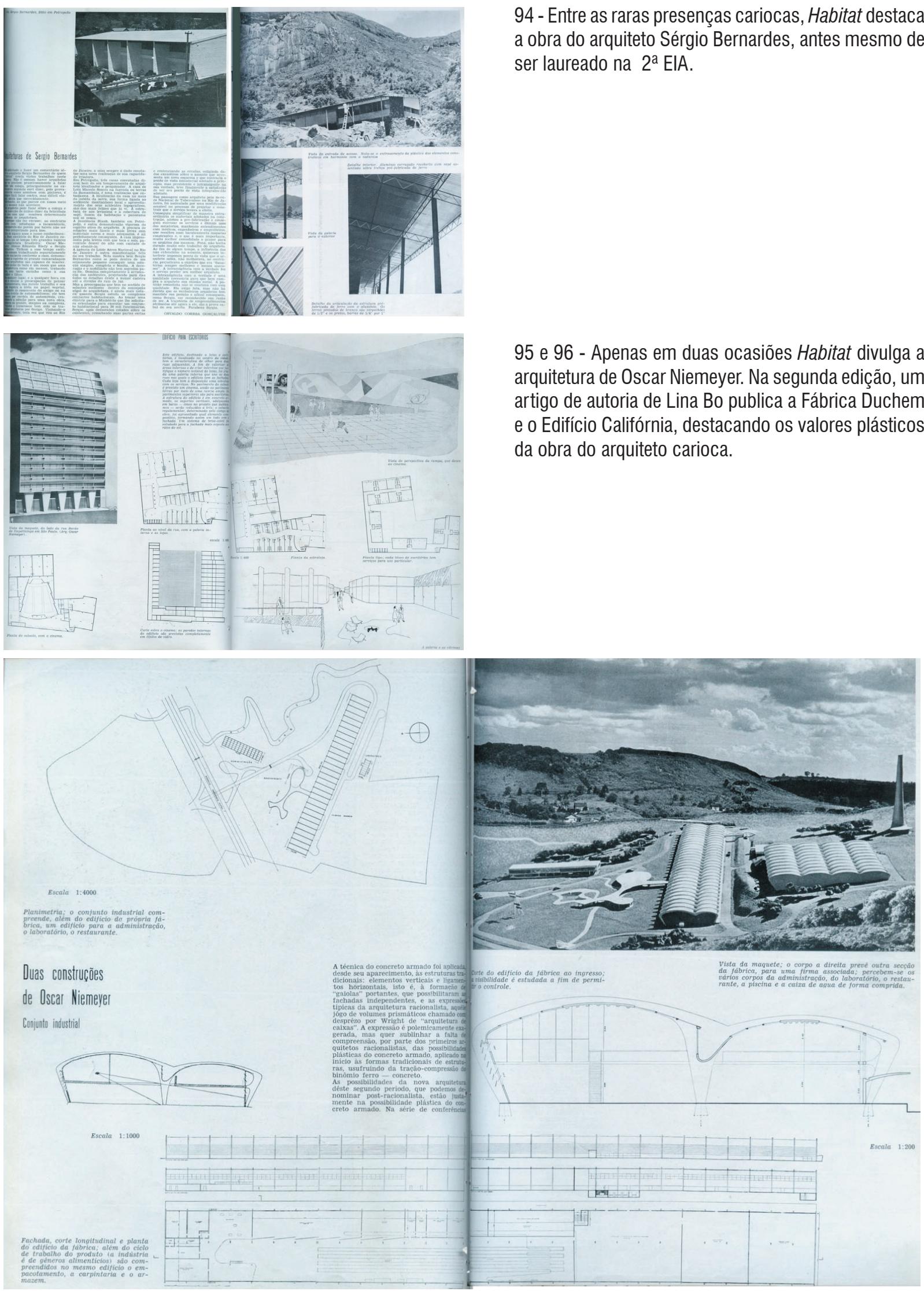

94 - Entre as raras presenças cariocas, Habitat destaca a obra do arquiteto Sérgio Bernardes, antes mesmo de ser laureado na $2^{\mathrm{a}}$ EIA.

95 e 96 - Apenas em duas ocasiões Habitat divulga a arquitetura de Oscar Niemeyer. Na segunda edição, um artigo de autoria de Lina Bo publica a Fábrica Duchem e o Edifício Califórnia, destacando os valores plásticos da obra do arquiteto carioca. 
entre os quais tem destaque novamente Abelardo de Souza. Radicado em São Paulo desde 1939 e com uma extensa produção marcada pela realização em parcerias, como a que estabeleceu com Hélio Duarte, sua obra caracteriza a transformação da paisagem paulistana naquele momento. Além da já destacada colaboração de Abelardo na revista, assinando artigos em torno da arquitetura moderna brasileira e do urbanismo, alguns projetos de sua autoria figuram como exemplos de ação alinhada a teoria divulgada em Habitat.

Pela análise da revista é possível afirmar que Habitat colabora na construção do panorama cultural de São Paulo, elegendo uma arquitetura entre as muitas produzidas pelos arquitetos que ali exerciam suas atividades. No entanto, nota-se que entre os profissionais comprometidos com a produção da arquitetura moderna faltam alguns nomes que naquele momento já detinham um reconhecimento público e uma obra relevante, como Eduardo Knesse de Mello, cujo compromisso com o MAM/SP, as Bienais e a revista Acrópole talvez possa explicar sua ausência.

Há ainda uma outra questão, que aparece ainda tímida nestes anos de Habitat, mas que anos depois caracterizará as realizações de Lina no Nordeste e em São Paulo: 0 enfrentamento entre o moderno e 0 antigo na arquitetura. Os exemplos da ação de Lina no Pelourinho e no Conjunto do Sesc Pompéia retratam a mesma forma de enfrentamento com que esta questão é abordada anos antes na revista por Flávio Motta.

Em “0 antigo e o novo Itamarati”, Habitat n 13 (1953), Flávio Motta apresenta a coerência presente no projeto de Henrique Mindlin que, preservando toda a atmosfera existente, claramente diferencia "o novo" do "existente" ao vencer o concurso para a ampliação do "velho edifício da rua Larga, o Palácio do Itamarati". 0 autor também faz referência ao projeto de Oscar Niemeyer para o hotel em Ouro Preto como o exemplo de atitude em relação ao patrimônio histórico e arquitetônico. Fotos, desenhos técnicos e ilustrações documentam fartamente a solução.

Vale listar aqui aqueles que escrevem sobre arquitetura e são publicados nas páginas dos primeiros quinze números de Habitat111: Abelardo de Souza, Affonso Reidy (carioca), Alfredo Mathias, Antonio José Capote Valente, Carlos Henrique Porto, Charles S. Bosworth, Eduardo Corona, Ernesto C. Mange, Giancarlo Palanti, Giò

\footnotetext{
${ }^{111}$ Verifica-se a recorrência dos nomes que estiveram presentes nas páginas de Habitat no período estudado e lista de congressistas do IV Congresso. São eles: Abelardo de Souza, Eduardo Corona, Ernesto Roberto Mange, Flávio Motta, Giancarlo Palanti, Icaro de Castro Mello, João B. Vilanova Artigas, Lina Bo Bardi, Oswaldo Corrêa Gonçaves, Rino Levi e Hélio Duarte de São Paulo; do Distrito Federal figuram Henrique Mindlin, Jorge Machado Moreira, Oscar Niemeyer, Roberto Burle Marx.
} 


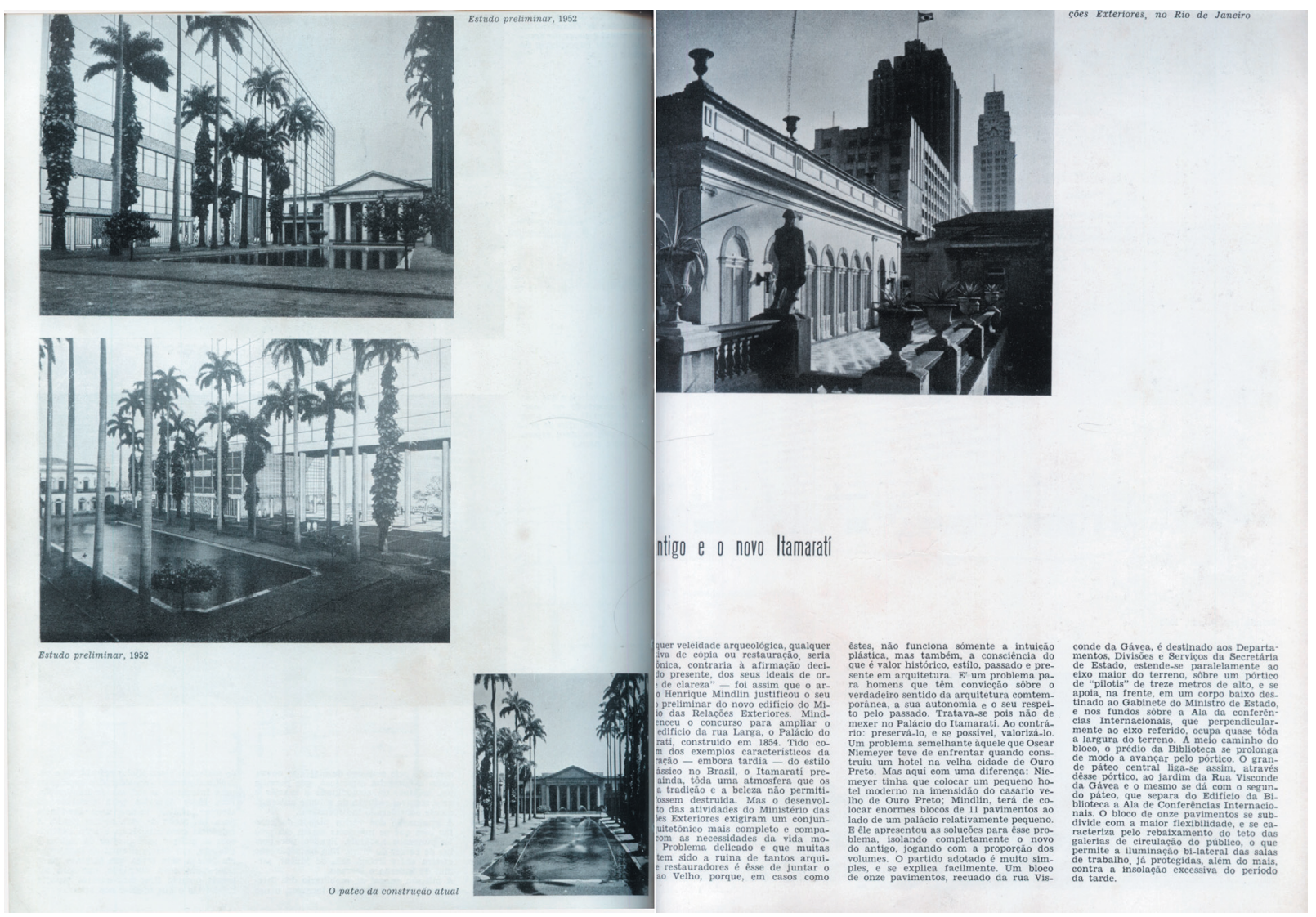

97 . Em "O antigo e o novo Itamaratí", Flávio Mota apresenta a coerência do projeto de Henrique Mindlin que respeitosamente intervem com o "novo" em um edifício "existente".

Ponti, Gregori Warchavichik, Gilberto Tinoco, Hélio Duarte, Henrique E. Mindlin, Ibsen Pivatelli, Icaro de Castro e Mello, Jorge M. Moreira (carioca), Wit-Olaf Prochnik, Lina Bo, Oswaldo Correia Gonçalves, Oswaldo Bratke, Oscar Niemayer (com sua produção em São Paulo), Roberto Tibau, Rino Levi, Sérgio Bernardes (carioca), Vilanova Artigas e Zenon Lotufo.

Pela identificação dos autores críticos de arquitetura e seus textos, dos arquitetos e projetos apresentados e analisados, é possível construir um quadro coerente entre o projeto editorial da revista Habitat inserido no projeto moderno de Lina e Pietro, e o projeto modernizador do país.

Na revista, a arquitetura, ao ser inserida no campo da cultura ao lado de outras manifestações artísticas, diferese e assume um compromisso social de transformação social. Assim, diferente de apenas publicar a produção de arquitetura em São Paulo, há em Habitat o compromisso de divulgar e caracterizar uma produção coerente com um projeto moderno que abrange as demais áreas de conhecimento, inserido na dinâmica da cidade de São Paulo nos anos 50. 


\section{Considerações Finais}

A revista Habitat apresenta-se como uma experiência bem-sucedida no período em que foi publicada, tendo sido lida com curiosidade e interesse pelos sempre poucos que se dedicam a arte e a arquitetura. No entanto, como um periódico, suas páginas correm o risco de se dispersarem com o passar do tempo, fato potencializado com o seu fim, que diminui de modo significativo a possibilidade de ter sua história reproduzida, afinal são os órgãos que permanecem abertos que têm oportunidade de resgatar sua própria memória.

Ainda que saibamos que a responsabilidade da criação de Habitat seja inteira de Pietro Maria Bardi e Lina Bo, cabe notar a importância de Assis Chateaubriand para sua existência.

Chatô pode ser visto como uma figura importante na realização do projeto moderno brasileiro que a partir dos Diários Associados e da sua "cadeia de comunicação" nacional colaborou para a caracterização de um país não apenas configurado pelos limites territoriais. Também colabora para a implantação desse projeto, a revisão de sua postura em relação aos primeiros sinais do movimento moderno no Brasil, quando passa a ceder espaço em seus órgãos de comunicação ainda nos anos $30^{1}$, e seu envolvimento no universo das artes, aqui destacado, que o levou a investir esforços na realização de um museu e convidar Pietro Maria Bardi para dirigi-lo; brindado com a inauguração do MASP em 1947.

0 MASP, além de conferir o reconhecimento no plano cultural ${ }^{2}$ a Chateaubriand, revela-se um dos mais importantes museus da América Latina e inaugura em São Paulo um período de intensas atividades artísticas e culturais, entre as quais podemos destacar os curso e mostras relacionadas ao meio publicitário, editorial e

\footnotetext{
${ }^{1}$ Contrário ao modernismo em seus primeiros anos, Chatô teria mostrado resignação ao convite de apoio feito por Graça Aranha, que lhe enviou antecipadamente o manifesto que marcaria a Semana de Arte Moderna de 1922. Revê sua postura a partir de 1926 convidando muitos dos primeiros modernistas para trabalhar em seus jornais, Carlos Drummond de Andrade e Oswald de Andrade; quando passa a assinar textos que saúdam artistas como Tarsila do Amaral e Lasar Segall; e com o lançamento em seu $O$ Diário de São Paulo da Revista de Antropofagia (segunda dentição). Ver MORAES (1994), op. cit., p.127.

${ }^{2}$ Outros empresários destacam-se neste momento no campo do mecenato. Além dos Matarazzo, a família Mesquita, proprietária de 0 Estado de S.Paulo, também esteve envolvida em importantes empreendimentos culturais, como a idealização do projeto da Universidade de São Paulo, fundada em 1934; na Revista Brasil (1916-1925), publicação de destaque no campo literário; e no patrocínio da revista Clima.
} 
gráfico, presentes nas escolas do Museu e divulgadas em Habitat.

As relações existentes entre 0 projeto cultural moderno de Lina Bo e Pietro e a obsessão de Chatô ${ }^{3}$ pela publicidade revelam nos interesses "econômicos" do empresário outras intenções, que as transforma em um projeto de modernidade ligado à imprensa, o qual, aliado as realizações do Museu, colabora para a formação de novos campos profissionais e a alteração do panorama cultural e artístico brasileiro.

Aliada as outras instituições e iniciativas do casal Bardi em seus primeiros anos de Brasil, Habitat aparece inserida em uma ação conjunta com o MASP, o IAC e o Studio de Arte Palma, os meios pelos quais realizariam aqui o seu projeto cultural. Como plataforma de afirmação do Movimento Moderno no país, esse projeto já caracterizado na Itália, revela-se em Habitat em sua coerência, a qual atribuímos a um projeto editorial maduro, possível pela bagagem anterior que Bardi e Lina trazem das experiências italianas, principalmente reveladas em Quadrante, Domus e Lo Stilo, periódicos que sobreviveram a condições tão ou mais adversas que as que 0 casal viriam a encontrar no Brasil.

Habitat, como uma invenção dos Bardi, assume um caráter múltiplo em seus primeiros anos, graças ao projeto editorial idealizado pelo casal que privilegia as diversas áreas de atuação do campo cultural. Com subtítulo Revista das Artes no Brasil, a revista aproxima a arte da vida cotidiana e apresenta para a sociedade moderna um novo papel. Era preciso compreender o novo campo de ação que o Brasil industrial apresentava. Assim, vemos na publicação a valorização na arte, na arquitetura e no desenho industrial, sob um racionalismo fundado no pensamento de Frei Carlo Lodoli, presente direta e indiretamente na revista desde o seu primeiro exemplar, pelo qual a forma está diretamente relacionada à matéria e, portanto, à técnica.

Neste mesmo sentido a revista destaca as atividades do Instituto de Arte Contemporânea ${ }^{4}$, que trabalha na formação e atualização de profissionais para atuar no desenho gráfico, no desenho industrial, na arte dos cartazes, na moda, no cinema e na tecelagem. Também a produção de móveis do Studio de Arte Palma é apresentada em Habitat, em sua preocupação com o desenho racional dos objetos somada ao respeito às características locais.

\footnotetext{
${ }^{3}$ Data de quase duas décadas antes da inauguração do MASP a criação por Chatô da primeira agência de publicidade e propaganda no Brasil. A fim de alavancar investimentos para seus jornais, inaugura o Departamento de Propaganda de 0 Jornal, coordenando pelo americano Fitz Gibbon. Sobre o assunto ver MORAES (1994), op. cit., p. 142.

${ }^{4}$ Sobre o IAC, ver LEON, Ethel. IAC Instituto de Arte Contemporânea: Escola de Desenho Industrial do MASP (1951-1953); primeiros estudos. São Paulo. Dissertação (mestrado). Faculdade de Arquitetura e Urbanismo de São Paulo, Universidade de São Paulo, 2006.
} 
A relação moderno-popular é central na arquitetura difundida por Habitat e é por essa via que a revista a insere no campo cultural brasileiro, conferindo-Ihe especificidade. Por meio dos textos de Lina, Habitat reconhece a presença na arquitetura popular de valores como a simplicidade construtiva e a racionalidade, que a aproxima da arquitetura moderna. Neste sentido, ao eleger a função e a técnica (que se traduzem em forma) como argumento, desvaloriza a "forma" como motivo principal da arquitetura. A esta arquitetura artisticamente social, pautada em fundamentos racionalistas é que a revista se detém.

Na sua posição de "fundir os tempos num só", não é pela aparência que a revista estabelece a relação entre a produção do passado e do moderno, mas pelos valores presentes na ordem da experiência, onde o presente é sempre um resultado do passado, uma etapa necessária; idéia defendida também na valorização do art nouveau por Flávio Motta.

0 compromisso de aproximar o erudito e o popular é dado na revista também em outras áreas, como, por exemplo, na valorização do pré-artesanato indígena, da capoeira e da arte naif; pela qual Habitat aponta a possibilidade de uma modernidade particular e brasileira.

Há também em Habitat um retrato das discussões internacionais que pautam a arquitetura moderna brasileira. Neste sentido, os escritos de Bardi, Lina, Abelardo de Souza e Flávio Motta constituem uma importante referência da cultura arquitetônica dos anos 50, em que podemos destacar dois momentos distintos: primeiro, o reconhecimento dos valores da "nossa arquitetura", apoiado na crítica internacional que destaca a influência de Le Cobusier, e que pode ser visto na revista pela extensa divulgação da exposição do arquiteto organizada pelo MASP. E, segundo, onde há o início da polêmica internacional em torno do risco que a arquitetura moderna brasileira assumia: a utilização do moderno como linguagem; representada em Habitat pelas críticas de Max Bill.

Presente ainda em Habitat estão as preocupações com o crescimento desenfreado das cidades e seu desenvolvimento, em que destacamos os textos de Abelardo que aponta, neste momento, para noções do que hoje chamamos de planejamento participativo, ao sugerir a necessidade da avaliação pelos cidadãos dos planos que deveriam ser executados por técnicos competentes.

Habitat aponta em seu discurso para uma arquitetura "engajada". Num tom que hoje pode nos parecer um tanto ingênuo e apaixonado, a revista apresenta tanto projetos com claras intenções sociais, como é a produção 
do "Convênio Escolar", quanto uma arquitetura realizada para a burguesia, exemplarmente vista nas casas de Artigas. Nesta última, a revista revela a responsabilidade da arquitetura em impor uma moral à vida pelo rigor e pela sobriedade, todos os espelhos do salão burguês seriam quebrados.

A importância do estudo da arquitetura na revista Habitat se dá, além do resgate de um importante periódico na história do amadurecimento da arquitetura moderna no Brasil, pela maneira que colabora para a estruturação de uma cultura arquitetônica e de um campo de ação profissional, que altera a representação que a arquitetura faz de si e de seu papel na sociedade.

Os motivos apresentados pelo casal ao "abandonar" Habitat no editorial da décima quinta edição - a conclusão da missão na revista e o acréscimo de compromissos no Museu - nos leva, como especulação, a apontar outros. Não seria também a crise do MASP quando tem a autenticidade de suas obras questionadas, somada ao sucesso alcançado pelas Bienais organizadas pelo MAM fatores que teriam colaborado para a sua saída? Afinal, a desqualificação da primeira e o sucesso da segunda caminham na contramão da posição defendida Lina e Pietro. Afinal, sabemos que a missão não termina ali, Bardi continuaria a trilhar um longo caminho à frente do MASP e Lina no MAM de Salvador, onde atuaria intensamente no reconhecimento dos valores da cultura local e na organização do artesanato e da indústria.

Este trabalho não pretende esgotar as questões apontadas pela revista, e, de longe, consegue de fato conhecer seu objeto, pela complexidade que apresenta e pela diversidade de leituras que se fazem possíveis a cada novo ponto de vista adotado. Acreditamos com ele colaborar no resgate de uma importante plataforma - que Habitat se coloca - de um projeto de ação cultural, no qual a arquitetura moderna aparece como constitutiva de um Brasil moderno, onde a coerência entre o pensamento e a ação impõe-se de tal maneira que o fazer artístico confunde-se à vida. A luta pela arte e pela arquitetura adquire uma importância vital que impossibilita separar Lina e Bardi de sua realização, suas aspirações sociais e morais impregnam os primeiros anos de Habitat, daí a Habitat de Bardi e Lina. 


\section{Bibliografia}

\section{Referencias Bibliográficas}

ARRUDA, Maria Arminda do Nascimento. Metrópole e cultura: São Paulo no meio do século XX. Bauru, SP: Edusc,2001. Bardi, Lina Bo. Contribuição propedêutica ao ensino da arquitetura. São Paulo, 1957.

--------. MASP - 40 anos. São Pulo, Crefisul.

--------. Sodalício com Assis Chateaubriand. São Paulo, MASP, 1982.

COSTA, L. Sobre Arquitetura. Porto Alegre, UFRGS,1962.

-------. Registro de uma vivência. São Paulo, Imprensa das Artes, 1995.

DURAND, José Carlos. Arte, Privilégio e Distinção. São Paulo, Perspectiva, 1989.

DE FUSCO, Renato. La ideia de arquitectura: história de la critica desde Viollet Le Duc a Pérsico. Barcelona, Gustavo Gili. 1976.

FERRAZ, Geraldo. Depois de tudo: Memórias, Rio de Janeiro, Paz e Terra/ Séc. Municipal de Cultura de São Paulo.

FERRAZ, Marcelo de Carvalho, coord. (1993) Lina Bo Bardi. São Paulo, Instituto Lina Bo e Pietro Maria Bardi

GO0DWIN, P.Brazil Builds. Architecture new and old.1652-1942.N. Y., MOMA, 1943.

LE CORBUSIER, Precisiones respecto a um Estado actual de la arquitectura e del urbanismo. Barcelona, Poseido. 1978.

LE CORBUSIER, Por uma arquitetura. São Paulo, Perspectiva. 1989.

LOURENÇO, M. C. F. Operários da Modernidade, São Paulo, EDUSP/HUCITEC, 1995.

-------. Museus Acolhem o Moderno, São Paulo, EDUSP/HUCITEC.

-------. Maioridade do Moderno em São Paulo. Anos 30 e 40, São Paulo, EDUSP/HUCITEC, 1999, pg.61.

MACHADO, Lourival Gomes. Retrato da arte moderna do Brasil, São Paulo. Departamento de cultura, 1947.

MINDLIN, H. Modern Architecture in Brasil, Rio de Janeiro, Colibris, 1956.

MORAES, Fernando. Chato o Rei o Brasil. São Paulo, Companhia da Letras, 1994.

NEVES, Juliana. Geraldo Ferraz e Patrícia Galvão: a experiência do Suplemento Literário do Diário de S. Paulo, nos anos 40. São Paulo: Annablume; Fapesp, 2005.

SANTOS, Cecília R. Le Corbusier e o Brasil. São Paulo, Tessala /Projeto, 1987.

TENTORI, F. (2000). PM Bardi: com as crônicas artísticas do "L'Ambrosiano" 1930-1933. Trad. por Eugênia Gorini Esmeraldo. São Paulo, Instituto Lina Bo e PM Bardi/ Imprensa Oficial do Estado.

Teses e dissertações e outros documentos

ANAIS do IV Congresso Brasileiro de Arquitetos. São Paulo, janeiro de 1954.

CAMPELLO, Maria de Fátima M.B. Lina Bo Bardi: as moradas da alma. São Carlos. Dissertação (mestrado) - Departamento de Arquitetura e Planejamento, Escola de Engenharia de São Carlos, Universidade de São Paulo,1997.

CONSTANTINO, Regina A. A obra de Abelardo de Souza. Dissertação (mestrado). Faculdade de Arquitetura e Urbanismo, Universidade de São Paulo, 2004.

HERBST, Helio. Promessas e conquistas - arquitetura e modernidade nas Bienais. Dissertação (mestrado). Faculdade de Arquitetura e Urbanismo, Universidade de São Paulo, 2002.

LEON, Ethel. IAC Instituito de Arte Contemporânea: Escola de Desenho Industrial do MASP (1951-1953); primeiros estudos. Faculdade de Arquitetura e Urbanismo de São Paulo, da Universidade de São Paulo, 2006.

MIRANDA, Clara Luiza. "A crítica nas revistas de arquitetura nos anos 50: a expressão plástica e a síntese das artes". Dissertação (mestrado) - Departamento de Arquitetura e Planejamento, Escola de Engenharia de São Carlos, Universidade de São Paulo,1998.

MARTINS, Carlos Alberto Ferreira. Arquitetura e Estado no Brasil: elementos para uma investigação sobre a Constituição do Discurso Modernista no Brasil; a obra de Lúcio Costa (1924-1952). São Paulo dissertação de mestrado, FFLCH-USP, 1988.

PEREIRA, J. A. A ação cultural de Lina Bo Bardi na Bahia e no Nordeste (1958-1964). São Carlos. Dissertação (mestrado) - Departamento de Arquitetura e Planejamento, Escola de Engenharia de São Carlos, Universidade de São Paulo,2001. 
SEGAWA, Hugo. Disseminando a linguagem arquitetônica carioca em São Paulo, Projeto nº105, São Paulo, 1987.

\section{Bibliografias consultadas ou pertinentes}

ACAYABA, Marlene Milan. Branco e Preto. Uma história do design brasileiro nos anos 50, Instituto Lina Bo e P.M. Bardi. AMARAL, Aracy. Projeto Construtivo brasileiro na arte: 1950-1962. Rio de Janeiro, Museu de Arte Moderna, São Paulo Biblioteca do Estado, 1977.

---------. Arte pra quê? A preocupação social na arte brasileira 1930-1970. São Paulo, Nobel, 1984.

AICHER, Otl. El Mundo Como Proyeto, Ediciones G. Gili, S. A. de C. V.

ARGAN, Giulio Carlo. Arte Moderna. São Paulo, Companhia das Letras,1992.

---------. Walter Gropius e La Bauhaus, Torino, einaudy, 1951.

ARTIGAS, J. B. Vilanova. Caminhos da Arquitetura. São Paulo, Lech.

--------. A função social do arquiteto. São Paulo, Editora Nobel,1989.

BARDI, Pietro Maria. Excursão ao Território do Design. São Paulo, Banco Sudameris, S. A., 1986.

---------. 0 design no Brasil, história e realidade. São Paulo, MASP, 1982.

BAYER, Herbert, Gropius, Walter \& Ise. Bauhaus. 1919 - 1928, The Museum of Modern Art, New York, 1938.

BAYEUX, Glória Maria. 0 Debate da Arquitetura Moderna Brasileira nos anos 50. São Paulo, dissertação de mestrado, FAU-USP, 1999.

BELLUZZO, A. M. Waldemar Cordeiro: uma aventura da razão. São Paulo, MAC/USP,1986.

BANHAM, R. Teoria e projeto na primeira era da máquina, São Paulo, Ed. Perspectiva,1975.

BENEVOLO, Leonardo. História de La Arquitetura Moderna. Madrid, Taurus Ediciones, 1963.

BONFANTI, E.; PORTA,M. (1973). Città, museo e architettura: /l grupo BBPR nella cultura architettonica italiana 19321970. Florença.

BRUAND, Y. Arquitetura Contemporânea no Brasil. São Paulo, Ed. Perspectiva, 1981.

DEBENEDETTI, E.; SALMONI, A. (1993). A Arquitetura italiana em São Paulo. São Paulo, Instituto Cultural Ítalo-Brasileiro.

ETLIN, Richard A. Modernism in italian architecture, 1890-1940. Cambridge, MIT Press.

FAROLDI, E. IVETTORI, M. P. (org.). Diálogos da Arquitetura. São Paulo, Ed. Siciliano, $1997 .$.

FRAMPTON, Kenneth, História crítica de La Arquitetura Moderna, ed. Gustavo Gili, S.A.

GIEDION, Sigfried. Arquitecture y comunidad, Buenos Aires, Ediciones Nueva Visión, 1963.

GREGOTTI, V. Território da Arquitetura, São Paulo; Perspectiva, 1975.

GROPIUS, Walter Adolf, Bauhaus: Nova Arquitetura, Tradução de J. Guinsburg Eingrid Dormien, 3a ed., Sãao Paulo; Perspectiva, 1977.

GULLAR, Ferreira. Cultura Posta em Questão, Rio de Janeiro, Editora Civilização Brasileira, 1965.

HUBER, A. (1997). II museo Italiano. Milão, Lybra.

JACOBS, J. Morte e Vida de Grandes Cidades, Martins Fontes, São Paulo, 2000.

ITTEN, Johannes. Design and Form: the basic course at the Bauhaus, translated by John Maass, New York, Reinhold, 1964.

KATINSKI, Julio. Apontamentos sobre Arte e Indústria, FAUUSP, São Paulo, 1963.

-------. Desenho Industrial, in Zanini, Walter (org.), História Geral da Arte no Brasil, São Paulo, Instituto Walter Moreira Sales, $2^{\circ}$ v., 1983.

-------. 0 concretismo e o desenho industrial. In AMARAL, Aracy (org). Projeto construtivo brasileiro na arte: 1950 -1962, p. 326-9.

MARTINS, A. L. Revistas em Revistas, São Paulo, EDUSP/ FAPESP, 2001.

MARTINO, Ludovico. I.A.C., in MOURA, Laís (org.), Design. Arte Vogue, São Paulo, nº 1, maio 1977.

MENEZES, Aureliano. A situação do móvel no Brasil. Do projeto à implantação industrial (anos 40 aos dias atuais). Depimentos. São Paulo, FAU - USP, 1977.

MONTANER, J. M. Después del Movimiento Moderno. Arquitectura de la segunda mitad del siglo XX. Barcelona, Editorial Dustavo Gili, 1993.

---------. La Modernidad Superada. Arquitectura, arte y pensamiento del siglo XX. Barcelona, Editorial Dustavo Gili, 1997.

NEUMANN, Eckhard. Buhaus and Bauhaus people: personal opinions and recollections of former Bauhaus menbers and 
their contemporaries, translation by Eva Richer and Alba Lorman.

PAGLIA, D. Arquitetura na Bienal de São Paulo. São Paulo, EDIAM,1952.

PEVSNER, Nikolaus. Os pioneiros do desenho moderno, Rio de Janeiro, Ulisséia, 1962.

PEDROSA, M. Mundo, Homem, Arte em Crise. São Paulo, Ed. Perspectiva, 1975.

--------. Dos Murais de Portinari aos Espaços de Brasília. São Paulo, Ed. Perspectiva, 1981.

REIS FILHO, N. G. (1970). Quadros da arquitetura no Brasil. São Paulo, Perspectiva.

ROGERS, E. N./ SERT, J. L./TYRWHITT, J. I/ Cuore della Cittá? Per uma vita piú umana delle comunitá, Congressi Internazionali de Architettura Moderna, Milano Hoepli Editore, 1977.

RUCHTI, Jacob. Composição/ notas de aulas. São Paulo, Instituto de Arte Contemporânea, 1951.

SANTOS, Maria Cecília Loschiavo. 0 móvel moderno no Brasil. Dissertação de mestrado apresentado à faculdade de Filosofia, Letras e Ciências Humanas da USP, 1985.

SCHUTZ, Alfred. 0 mundo artístico do Brasil: enciclopédia biográfica sobre todos os setores da arte brasileira. Rio de janeiro, Pró-arte, 1954.

SEGAWA, H.M. Arquiteturas no Brasil, 1900-1990. São Paulo, Editora da Universidade de São Paulo, 2002.

---------. Arquiteturas no Brasil, anos 80. São Paulo, Projeto Editores Associados, 1988.

SOUZA, Abelardo de. Arquitetura no Brasil depoimentos de Abelardo de Souza. 1978.

TAFURI, M./DAL C0, F. Architettura Contemporanea, Milano, Electa,1979.

TORRES, Mauricio. 0 design brasileiro ainda sem estilo, Qual será o seu futuro?, in Jornal do brasil, Rio de Janeiro, 30 07-1975.

WICK, Rainer. Pedagogia da Bauhaus, tradução de João Azenha Jr., Editora Martins Fontes, LTDA, São Paulo, 1989.

O DESIGN NO BRASIL - história e realidade. Exposição inaugural do Centro de Lazer - SESC, Fábrica Pompéia, 1982, Museu de Arte Assis Chateaubriand.

XAVIER, Alberto. Arquitetura Moderna Brasileira. Depoimento de uma Geração. São Paulo, ABEA/PINI, 1987.

ZANINI, Walter. História geral da arte no Brasil. São Paulo, Instituto Walther Moreira Salles, $2^{\circ}$ volume.

ZEVI, Bruno. Saber ver a arquitetura. Lisboa, Arcadia, 1966.

Teses e dissertações e outros documentos

ANELLI, Renato L.S. Arquitetura e cidade na obra de Rino Levi. São Paulo. Tese (doutorado) - Faculdade de Arquitetura e Urbanismo, Universidade de São Paulo,1995.

CABRAL, M.C.N. O Racionalismo arquitetônico de Lina Bo Bardi. Rio de Janeiro. Dissertação (mestrado) - Pontifícia Universidade Católica, 1996.

SANTOS, L. C. Arquitetura Paulista em torno de 1930-1940. Dissertação (mestrado). Faculdade de Arquitetura e Urbanismo, Universidade de São Paulo, 1985.

ANELLI, R.L.S. Mediterráneo en los trópicos. Revista Block - n.4, Buenos Aires, 1999.

MARTINS, C. A. F. Estado, cultura e natureza na origem da arquitetura moderna brasileira: Le Corbusier e Lúcio Costa, 1929-1936. Revista Caramelo, n.6.

ROCHA, Paulo M. Depoimentos sobre Flávio Mota. Revista Caramelo, n.6, p.41-53, 1993.

FERRAZ, Geraldo. Novos valores da Arq. Brasileira - Abelardo Riedy de Souza. Revista Habitat n.39. 1957. 
ANEXOS 
ÍNDICE DO EXPEDIENTE DA REVISTA HABITAT

\begin{tabular}{|c|c|c|c|c|c|c|c|c|c|c|}
\hline PUBLICAÇÃO & ANO & PERÍODO & $\begin{array}{l}\text { DIRETOR } \\
\text { GERAL }\end{array}$ & $\begin{array}{c}\text { DIRETOR } \\
\text { RESPONSÁVEL }\end{array}$ & EDITOR & REDATOR & $\begin{array}{l}\text { REDATOR- } \\
\text { CHEFE }\end{array}$ & $\begin{array}{l}\text { DIRECCÃO } \\
\text { DE ARTES } \\
\text { PLÁSTICA }\end{array}$ & $\begin{array}{c}\text { DIRECÃO DE } \\
\text { ARQUITETURA }\end{array}$ & $\begin{array}{l}\text { CARGOS } \\
\text { ESPECIAIS }\end{array}$ \\
\hline 01 & 1950 & $\begin{array}{l}\text { OUTUBRO/ } \\
\text { NOVEMBRO/ } \\
\text { DEZEMBRO }\end{array}$ & $\begin{array}{l}\text { Lina Bo } \\
\text { Bardi }\end{array}$ & $\begin{array}{l}\text { Geraldo N. } \\
\text { Serra }\end{array}$ & & & & & & \\
\hline 02 & 1951 & $\begin{array}{c}\text { JANEIRO/ FEVEREIRO/ } \\
\text { MARÇO }\end{array}$ & $\begin{array}{l}\text { Lina Bo } \\
\text { Bardi }\end{array}$ & $\begin{array}{l}\text { Geraldo N. } \\
\text { Serra }\end{array}$ & & & & & & \\
\hline 03 & 1951 & ABRIL/ MAIO/ JUNHO & $\begin{array}{l}\text { Lina Bo } \\
\text { Bardi }\end{array}$ & $\begin{array}{l}\text { Geraldo N. } \\
\text { Serra }\end{array}$ & & & & & & \\
\hline 04 & 1951 & $\begin{array}{c}\text { JULHO/ AGOSTO/ } \\
\text { SETEMBRO }\end{array}$ & $\begin{array}{l}\text { Lina Bo } \\
\text { Bardi }\end{array}$ & $\begin{array}{l}\text { Geraldo N. } \\
\text { Serra }\end{array}$ & & & & & & \\
\hline 05 & 1951 & $\begin{array}{l}\text { OUTUBRO/ } \\
\text { NOVEMBRO/ } \\
\text { DEZEMBRO }\end{array}$ & $\begin{array}{l}\text { Lina Bo } \\
\text { Bardi }\end{array}$ & $\begin{array}{l}\text { Geraldo N. } \\
\text { Serra }\end{array}$ & & & & & & \\
\hline 06 & 1952 & $\begin{array}{c}\text { JANEIRO/ FEVEREIRO/ } \\
\text { MARÇO }\end{array}$ & $\begin{array}{l}\text { Lina Bo } \\
\text { Bardi }\end{array}$ & $\begin{array}{l}\text { Geraldo N. } \\
\text { Serra }\end{array}$ & & & & & & \\
\hline 07 & 1952 & ABRIL/ MAIO/ JUNHO & $\begin{array}{l}\text { Lina Bo } \\
\text { Bardi }\end{array}$ & $\begin{array}{l}\text { Geraldo N. } \\
\text { Serra }\end{array}$ & & & & & & \\
\hline 08 & 1952 & $\begin{array}{c}\text { JULHO/ AGOSTO/ } \\
\text { SETEMBRO }\end{array}$ & $\begin{array}{l}\text { Lina Bo } \\
\text { Bardi }\end{array}$ & $\begin{array}{c}\text { Geraldo N. } \\
\text { Serra }\end{array}$ & & & & & & \\
\hline 09 & 1952 & $\begin{array}{c}\text { OUTUBRO/ } \\
\text { NOVEMBRO/ } \\
\text { DEZEMBRO }\end{array}$ & $\begin{array}{l}\text { Lina Bo } \\
\text { Bardi }\end{array}$ & $\begin{array}{l}\text { Geraldo N. } \\
\text { Serra }\end{array}$ & & & & & & \\
\hline 10 & 1953 & $\begin{array}{c}\text { JANEIRO/ FEVEREIRO/ } \\
\text { MARÇO }\end{array}$ & $\begin{array}{l}\text { Flávio } \\
\text { Motta }\end{array}$ & $\begin{array}{c}\text { Geraldo N. } \\
\text { Serra }\end{array}$ & & & & & & \\
\hline 11 & 1953 & ABRIL/ MAIO/ JUNHO & $\begin{array}{l}\text { Flávio } \\
\text { Motta }\end{array}$ & $\begin{array}{l}\text { Geraldo N. } \\
\text { Serra }\end{array}$ & & & & & & \\
\hline 12 & 1953 & $\begin{array}{c}\text { JULHO/ AGOSTO/ } \\
\text { SETEMBRO }\end{array}$ & $\begin{array}{l}\text { Flávio } \\
\text { Motta }\end{array}$ & $\begin{array}{l}\text { Geraldo N. } \\
\text { Serra }\end{array}$ & & & & & & \\
\hline 13 & 1953 & $\begin{array}{l}\text { OUTUBRO/ } \\
\text { NOVEMBRO/ } \\
\text { DEZEMBRO } \\
\end{array}$ & $\begin{array}{l}\text { Flávio } \\
\text { Motta }\end{array}$ & $\begin{array}{l}\text { Geraldo N. } \\
\text { Serra }\end{array}$ & & & & & & \\
\hline 14 & 1954 & JANEIRO/ FEVEREIRO & $\begin{array}{c}\text { Lina Bo } \\
\text { Bardi/ } \\
\text { Pietro Maria } \\
\text { Bardi }\end{array}$ & $\begin{array}{l}\text { Geraldo N. } \\
\text { Serra }\end{array}$ & & & & & & \\
\hline 15 & 1954 & MARÇO/ ABRIL & $\begin{array}{c}\text { Lina Bo } \\
\text { Bardi/ } \\
\text { Pietro Maria } \\
\text { Bardi } \\
\end{array}$ & $\begin{array}{l}\text { Geraldo N. } \\
\text { Serra }\end{array}$ & & & & & & \\
\hline 16 & 1954 & MAIO/ JUNHO & $\begin{array}{l}\text { cargo } \\
\text { extinto }\end{array}$ & $\begin{array}{l}\text { Geraldo N. } \\
\text { Serra }\end{array}$ & $\begin{array}{l}\text { Rodolfo } \\
\text { Klein }\end{array}$ & & & $\begin{array}{l}\text { José } \\
\text { Geraldo } \\
\text { Vieira }\end{array}$ & $\begin{array}{l}\text { Abelardo de } \\
\text { Souza }\end{array}$ & \\
\hline 17 & 1954 & JULHO/ AGOSTO & $\begin{array}{l}\text { cargo } \\
\text { extinto }\end{array}$ & $\begin{array}{l}\text { Geraldo N. } \\
\text { Serra }\end{array}$ & $\begin{array}{l}\text { Rodolfo } \\
\text { Klein }\end{array}$ & & & $\begin{array}{l}\text { José } \\
\text { Geraldo } \\
\text { Vieira }\end{array}$ & $\begin{array}{l}\text { Abelardo de } \\
\text { Souza }\end{array}$ & \\
\hline 18 & 1954 & SETEMBRO/ OUTUBRO & $\begin{array}{l}\text { cargo } \\
\text { extinto }\end{array}$ & $\begin{array}{c}\text { Geraldo N. } \\
\text { Serra }\end{array}$ & $\begin{array}{l}\text { Rodolfo } \\
\text { Klein }\end{array}$ & & & $\begin{array}{l}\text { José } \\
\text { Geraldo } \\
\text { Vieira }\end{array}$ & $\begin{array}{l}\text { Abelardo de } \\
\text { Souza }\end{array}$ & \\
\hline 19 & 1954 & $\begin{array}{l}\text { NOVEMBRO/ } \\
\text { DEZEMBRO }\end{array}$ & $\begin{array}{l}\text { cargo } \\
\text { extinto }\end{array}$ & $\begin{array}{l}\text { Geraldo N. } \\
\text { Serra }\end{array}$ & & & & $\begin{array}{l}\text { José } \\
\text { Geraldo } \\
\text { Vieira }\end{array}$ & $\begin{array}{l}\text { Abelardo de } \\
\text { Souza }\end{array}$ & $\begin{array}{c}\text { DIRETOR } \\
\text { DE TEATRO } \\
\text { - Ruggero } \\
\text { Jacobbi } \\
\text { DIRETOR DE } \\
\text { LITERATURA } \\
\text { - Maria de } \\
\text { Lourdes } \\
\text { Teixeira }\end{array}$ \\
\hline 20 & 1955 & JANEIRO/ FEVEREIRO & $\begin{array}{l}\text { cargo } \\
\text { extinto }\end{array}$ & $\begin{array}{l}\text { Geraldo N. } \\
\text { Serra }\end{array}$ & & & & $\begin{array}{l}\text { José } \\
\text { Geraldo } \\
\text { Vieira }\end{array}$ & $\begin{array}{l}\text { Abelardo de } \\
\text { Souza }\end{array}$ & $\begin{array}{c}\text { DIRETOR } \\
\text { DE TEATRO } \\
\text { - Ruggero } \\
\text { Jacobbi } \\
\text { DIRETOR DE } \\
\text { LITERATURA } \\
\text { - Maria de } \\
\text { Lourdes } \\
\text { Teixeira }\end{array}$ \\
\hline
\end{tabular}




\begin{tabular}{|c|c|c|c|c|c|c|c|c|c|}
\hline 21 & 1955 & MARÇO/ ABRIL & $\begin{array}{l}\text { cargo } \\
\text { extinto }\end{array}$ & $\begin{array}{l}\text { Geraldo N. } \\
\text { Serra }\end{array}$ & & & $\begin{array}{l}\text { José } \\
\text { Geraldo } \\
\text { Vieira }\end{array}$ & Abelardo de & $\begin{array}{l}\text { DIRETOR } \\
\text { DE TEATRO } \\
\text { - Ruggero } \\
\text { Jacobbi } \\
\text { DIRETOR DE } \\
\text { LITERATURA } \\
\text { - Maria de } \\
\text { Lourdes } \\
\text { Teixeira }\end{array}$ \\
\hline 22 & 1955 & MAIO/ JUNHO & $\begin{array}{l}\text { cargo } \\
\text { extinto }\end{array}$ & $\begin{array}{l}\text { Geraldo N. } \\
\text { Serra }\end{array}$ & & & DIREÇÃO E & $\begin{array}{l}\text { Abelardo de } \\
\text { Souza }\end{array}$ & \\
\hline 23 & 1955 & JULHO/ AGOSTO & $\begin{array}{l}\text { cargo } \\
\text { extinto }\end{array}$ & $\begin{array}{l}\text { Geraldo N. } \\
\text { Serra }\end{array}$ & & & DIREÇÃO E & $\begin{array}{l}\text { Abelardo de } \\
\text { Souza }\end{array}$ & \\
\hline 24 & 1955 & SETEMBRO/ OUTUBRO & $\begin{array}{l}\text { cargo } \\
\text { extinto }\end{array}$ & $\begin{array}{l}\text { Geraldo N. } \\
\text { Serra }\end{array}$ & & & DIREÇÃO E & $=\begin{array}{c}\text { Abelardo de } \\
\text { Souza }\end{array}$ & \\
\hline 25 & 1955 & $\begin{array}{l}\text { NOVEMBRO/ } \\
\text { DEZEMBRO }\end{array}$ & $\begin{array}{l}\text { cargo } \\
\text { extinto }\end{array}$ & $\begin{array}{l}\text { Geraldo N. } \\
\text { Serra }\end{array}$ & $\begin{array}{l}\text { Rodolfo } \\
\text { Klein }\end{array}$ & $\begin{array}{c}\text { Geraldo N. } \\
\text { Serra }\end{array}$ & $\begin{array}{l}\text { José } \\
\text { Geraldo } \\
\text { Vieira }\end{array}$ & $\begin{array}{l}\text { Geraldo } \\
\text { Ferraz }\end{array}$ & \\
\hline 26 & 1956 & JANEIRO & $\begin{array}{l}\text { cargo } \\
\text { extinto }\end{array}$ & $\begin{array}{l}\text { Geraldo N. } \\
\text { Serra }\end{array}$ & $\begin{array}{l}\text { Rodolfo } \\
\text { Klein }\end{array}$ & $\begin{array}{c}\text { Geraldo N. } \\
\text { Serra }\end{array}$ & $\begin{array}{c}\text { José } \\
\text { Geraldo } \\
\text { Vieira }\end{array}$ & $\begin{array}{l}\text { Geraldo } \\
\text { Ferraz }\end{array}$ & \\
\hline 27 & 1956 & FEVEREIRO & $\begin{array}{l}\text { cargo } \\
\text { extinto }\end{array}$ & $\begin{array}{l}\text { Geraldo N. } \\
\text { Serra }\end{array}$ & $\begin{array}{l}\text { Rodolfo } \\
\text { Klein }\end{array}$ & $\begin{array}{c}\text { Geraldo N. } \\
\text { Serra }\end{array}$ & $\begin{array}{c}\text { José } \\
\text { Geraldo } \\
\text { Vieira } \\
\end{array}$ & $\begin{array}{l}\text { Geraldo } \\
\text { Ferraz }\end{array}$ & \\
\hline 28 & 1956 & MARÇO & $\begin{array}{l}\text { cargo } \\
\text { extinto }\end{array}$ & $\begin{array}{l}\text { Geraldo N. } \\
\text { Serra }\end{array}$ & $\begin{array}{l}\text { Rodolfo } \\
\text { Klein }\end{array}$ & $\begin{array}{c}\text { Geraldo N. } \\
\text { Serra }\end{array}$ & $\begin{array}{c}\text { José } \\
\text { Geraldo } \\
\text { Vieira }\end{array}$ & $\begin{array}{l}\text { Geraldo } \\
\text { Ferraz }\end{array}$ & \\
\hline 29 & 1956 & ABRIL & $\begin{array}{l}\text { cargo } \\
\text { extinto }\end{array}$ & $\begin{array}{l}\text { Geraldo N. } \\
\text { Serra }\end{array}$ & $\begin{array}{l}\text { Rodolfo } \\
\text { Klein }\end{array}$ & $\begin{array}{c}\text { Geraldo N. } \\
\text { Serra }\end{array}$ & $\begin{array}{c}\text { José } \\
\text { Geraldo } \\
\text { Vieira }\end{array}$ & $\begin{array}{l}\text { Geraldo } \\
\text { Ferraz }\end{array}$ & \\
\hline 30 & 1956 & MAIO & $\begin{array}{l}\text { cargo } \\
\text { extinto }\end{array}$ & $\begin{array}{l}\text { Geraldo N. } \\
\text { Serra }\end{array}$ & $\begin{array}{l}\text { Rodolfo } \\
\text { Klein }\end{array}$ & $\begin{array}{c}\text { Geraldo N. } \\
\text { Serra }\end{array}$ & $\begin{array}{c}\text { José } \\
\text { Geraldo } \\
\text { Vieira }\end{array}$ & $\begin{array}{l}\text { Geraldo } \\
\text { Ferraz }\end{array}$ & \\
\hline 31 & 1956 & JUNHO & $\begin{array}{l}\text { cargo } \\
\text { extinto }\end{array}$ & $\begin{array}{l}\text { Geraldo N. } \\
\text { Serra }\end{array}$ & $\begin{array}{l}\text { Rodolfo } \\
\text { Klein }\end{array}$ & $\begin{array}{c}\text { Geraldo N. } \\
\text { Serra }\end{array}$ & $\begin{array}{c}\text { José } \\
\text { Geraldo } \\
\text { Vieira }\end{array}$ & $\begin{array}{l}\text { Geraldo } \\
\text { Ferraz }\end{array}$ & \\
\hline 32 & 1956 & JULHO & $\begin{array}{l}\text { cargo } \\
\text { extinto }\end{array}$ & $\begin{array}{l}\text { Geraldo N. } \\
\text { Serra }\end{array}$ & $\begin{array}{l}\text { Rodolfo } \\
\text { Klein }\end{array}$ & $\begin{array}{c}\text { Geraldo N. } \\
\text { Serra }\end{array}$ & $\begin{array}{l}\text { José } \\
\text { Geraldo } \\
\text { Vieira } \\
\end{array}$ & $\begin{array}{l}\text { Geraldo } \\
\text { Ferraz }\end{array}$ & \\
\hline 33 & 1956 & AGOSTO & $\begin{array}{l}\text { cargo } \\
\text { extinto }\end{array}$ & $\begin{array}{l}\text { Geraldo N. } \\
\text { Serra }\end{array}$ & $\begin{array}{l}\text { Rodolfo } \\
\text { Klein }\end{array}$ & $\begin{array}{c}\text { Geraldo N. } \\
\text { Serra }\end{array}$ & $\begin{array}{c}\text { José } \\
\text { Geraldo } \\
\text { Vieira } \\
\end{array}$ & $\begin{array}{l}\text { Geraldo } \\
\text { Ferraz }\end{array}$ & \\
\hline 34 & 1956 & SETEMBRO & $\begin{array}{l}\text { cargo } \\
\text { extinto }\end{array}$ & $\begin{array}{l}\text { Geraldo N. } \\
\text { Serra }\end{array}$ & $\begin{array}{l}\text { Rodolfo } \\
\text { Klein }\end{array}$ & $\begin{array}{c}\text { Geraldo N. } \\
\text { Serra }\end{array}$ & $\begin{array}{c}\text { José } \\
\text { Geraldo } \\
\text { Vieira } \\
\end{array}$ & $\begin{array}{l}\text { Geraldo } \\
\text { Ferraz }\end{array}$ & \\
\hline 35 & 1956 & OUTUBRO & $\begin{array}{l}\text { cargo } \\
\text { extinto }\end{array}$ & $\begin{array}{l}\text { Geraldo N. } \\
\text { Serra }\end{array}$ & $\begin{array}{l}\text { Rodolfo } \\
\text { Klein }\end{array}$ & $\begin{array}{c}\text { Geraldo N. } \\
\text { Serra }\end{array}$ & $\begin{array}{c}\text { José } \\
\text { Geraldo } \\
\text { Vieira } \\
\end{array}$ & $\begin{array}{l}\text { Geraldo } \\
\text { Ferraz }\end{array}$ & \\
\hline 36 & 1956 & NOVEMBRO & $\begin{array}{l}\text { cargo } \\
\text { extinto }\end{array}$ & $\begin{array}{l}\text { Geraldo N. } \\
\text { Serra }\end{array}$ & $\begin{array}{l}\text { Rodolfo } \\
\text { Klein }\end{array}$ & $\begin{array}{c}\text { Geraldo N. } \\
\text { Serra }\end{array}$ & $\begin{array}{c}\text { José } \\
\text { Geraldo } \\
\text { Vieira }\end{array}$ & $\begin{array}{l}\text { Geraldo } \\
\text { Ferraz }\end{array}$ & \\
\hline 37 & 1956 & DEZEMBRO & $\begin{array}{l}\text { cargo } \\
\text { extinto }\end{array}$ & $\begin{array}{l}\text { Geraldo N. } \\
\text { Serra }\end{array}$ & $\begin{array}{l}\text { Rodolfo } \\
\text { Klein }\end{array}$ & $\begin{array}{c}\text { Geraldo N. } \\
\text { Serra }\end{array}$ & $\begin{array}{c}\text { José } \\
\text { Geraldo } \\
\text { Vieira } \\
\end{array}$ & $\begin{array}{l}\text { Geraldo } \\
\text { Ferraz }\end{array}$ & \\
\hline 38 & 1957 & JANEIRO & $\begin{array}{l}\text { cargo } \\
\text { extinto }\end{array}$ & $\begin{array}{c}\text { Geraldo N. } \\
\text { Serra }\end{array}$ & $\begin{array}{l}\text { Rodolfo } \\
\text { Klein }\end{array}$ & $\begin{array}{c}\text { Geraldo N. } \\
\text { Serra }\end{array}$ & $\begin{array}{c}\text { José } \\
\text { Geraldo } \\
\text { Vieira }\end{array}$ & $\begin{array}{l}\text { Geraldo } \\
\text { Ferraz }\end{array}$ & \\
\hline
\end{tabular}




\begin{tabular}{|c|c|c|c|c|c|c|c|c|c|}
\hline 39 & 1957 & FEVEREIRO & $\begin{array}{l}\text { cargo } \\
\text { extinto }\end{array}$ & $\begin{array}{l}\text { Geraldo N. } \\
\text { Serra }\end{array}$ & $\begin{array}{l}\text { Rodolfo } \\
\text { Klein }\end{array}$ & $\begin{array}{l}\text { Geraldo N. } \\
\text { Serra }\end{array}$ & $\begin{array}{c}\text { José } \\
\text { Geraldo } \\
\text { Vieira }\end{array}$ & $\begin{array}{l}\text { Geraldo } \\
\text { Ferraz }\end{array}$ & $\begin{array}{c}\text { SECRETÁRIA } \\
\text { - Wanda } \\
\text { Svevo } \\
\end{array}$ \\
\hline 40 & 1957 & MARÇO/ ABRIL & $\begin{array}{l}\text { cargo } \\
\text { extinto }\end{array}$ & $\begin{array}{l}\text { Geraldo N. } \\
\text { Serra }\end{array}$ & $\begin{array}{l}\text { Rodolfo } \\
\text { Klein }\end{array}$ & $\begin{array}{l}\text { Geraldo N. } \\
\text { Serra }\end{array}$ & $\begin{array}{c}\text { José } \\
\text { Geraldo } \\
\text { Vieira }\end{array}$ & $\begin{array}{l}\text { Geraldo } \\
\text { Ferraz }\end{array}$ & $\begin{array}{c}\text { SECRETÁRIA } \\
\text { - Suzana } \\
\text { Klein } \\
\end{array}$ \\
\hline 41 & 1957 & MARÇO/ ABRIL & $\begin{array}{l}\text { cargo } \\
\text { extinto }\end{array}$ & $\begin{array}{l}\text { Geraldo N. } \\
\text { Serra }\end{array}$ & $\begin{array}{l}\text { Rodolfo } \\
\text { Klein }\end{array}$ & $\begin{array}{l}\text { Geraldo N. } \\
\text { Serra }\end{array}$ & $\begin{array}{c}\text { José } \\
\text { Geraldo } \\
\text { Vieira }\end{array}$ & $\begin{array}{l}\text { Geraldo } \\
\text { Ferraz }\end{array}$ & \\
\hline 42 & 1957 & MAIO/ JUNHO & $\begin{array}{l}\text { cargo } \\
\text { extinto }\end{array}$ & $\begin{array}{l}\text { Geraldo N. } \\
\text { Serra }\end{array}$ & $\begin{array}{l}\text { Rodolfo } \\
\text { Klein }\end{array}$ & $\begin{array}{l}\text { Geraldo N. } \\
\text { Serra }\end{array}$ & $\begin{array}{c}\text { José } \\
\text { Geraldo } \\
\text { Vieira }\end{array}$ & $\begin{array}{l}\text { Geraldo } \\
\text { Ferraz }\end{array}$ & \\
\hline 43 & 1957 & JULHO/ AGOSTO & $\begin{array}{c}\text { cargo } \\
\text { extinto }\end{array}$ & $\begin{array}{l}\text { Geraldo N. } \\
\text { Serra }\end{array}$ & $\begin{array}{l}\text { Rodolfo } \\
\text { Klein }\end{array}$ & $\begin{array}{l}\text { Geraldo N. } \\
\text { Serra }\end{array}$ & $\begin{array}{c}\text { José } \\
\text { Geraldo } \\
\text { Vieira }\end{array}$ & $\begin{array}{l}\text { Geraldo } \\
\text { Ferraz }\end{array}$ & \\
\hline 44 & 1957 & SETEMBRO/ OUTUBRO & $\begin{array}{l}\text { cargo } \\
\text { extinto }\end{array}$ & $\begin{array}{l}\text { Geraldo N. } \\
\text { Serra }\end{array}$ & $\begin{array}{l}\text { Rodolfo } \\
\text { Klein }\end{array}$ & $\begin{array}{l}\text { Geraldo N. } \\
\text { Serra }\end{array}$ & $\begin{array}{c}\text { José } \\
\text { Geraldo } \\
\text { Vieira }\end{array}$ & $\begin{array}{l}\text { Geraldo } \\
\text { Ferraz }\end{array}$ & \\
\hline 45 & 1957 & $\begin{array}{l}\text { NOVEMBRO/ } \\
\text { DEZEMBRO }\end{array}$ & $\begin{array}{l}\text { cargo } \\
\text { extinto }\end{array}$ & $\begin{array}{l}\text { Geraldo N. } \\
\text { Serra }\end{array}$ & $\begin{array}{l}\text { Rodolfo } \\
\text { Klein }\end{array}$ & $\begin{array}{l}\text { Geraldo N. } \\
\text { Serra }\end{array}$ & $\begin{array}{l}\text { José } \\
\text { Geraldo } \\
\text { Vieira }\end{array}$ & $\begin{array}{l}\text { Geraldo } \\
\text { Ferraz }\end{array}$ & \\
\hline 46 & 1958 & JANEIRO/ FEVEREIRO & $\begin{array}{l}\text { cargo } \\
\text { extinto }\end{array}$ & $\begin{array}{l}\text { Geraldo N. } \\
\text { Serra }\end{array}$ & $\begin{array}{l}\text { Rodolfo } \\
\text { Klein }\end{array}$ & $\begin{array}{l}\text { Geraldo N. } \\
\text { Serra }\end{array}$ & $\begin{array}{c}\text { José } \\
\text { Geraldo } \\
\text { Vieira }\end{array}$ & $\begin{array}{l}\text { Geraldo } \\
\text { Ferraz }\end{array}$ & \\
\hline 47 & 1958 & MARÇO/ ABRIL & $\begin{array}{l}\text { cargo } \\
\text { extinto }\end{array}$ & $\begin{array}{l}\text { Geraldo N. } \\
\text { Serra }\end{array}$ & $\begin{array}{l}\text { Rodolfo } \\
\text { Klein }\end{array}$ & $\begin{array}{l}\text { Geraldo N. } \\
\text { Serra }\end{array}$ & $\begin{array}{c}\text { José } \\
\text { Geraldo } \\
\text { Vieira }\end{array}$ & $\begin{array}{l}\text { Geraldo } \\
\text { Ferraz }\end{array}$ & \\
\hline 48 & 1958 & MAIO/ JUNHO & $\begin{array}{l}\text { cargo } \\
\text { extinto }\end{array}$ & $\begin{array}{l}\text { Geraldo N. } \\
\text { Serra }\end{array}$ & $\begin{array}{l}\text { Rodolfo } \\
\text { Klein }\end{array}$ & $\begin{array}{l}\text { Geraldo N. } \\
\text { Serra }\end{array}$ & $\begin{array}{c}\text { José } \\
\text { Geraldo } \\
\text { Vieira }\end{array}$ & $\begin{array}{l}\text { Geraldo } \\
\text { Ferraz }\end{array}$ & \\
\hline 49 & 1958 & JULHO/ AGOSTO & $\begin{array}{l}\text { cargo } \\
\text { extinto }\end{array}$ & $\begin{array}{l}\text { Geraldo N. } \\
\text { Serra }\end{array}$ & $\begin{array}{l}\text { Rodolfo } \\
\text { Klein }\end{array}$ & $\begin{array}{l}\text { Geraldo N. } \\
\text { Serra }\end{array}$ & $\begin{array}{l}\text { José } \\
\text { Geraldo } \\
\text { Vieira }\end{array}$ & $\begin{array}{l}\text { Geraldo } \\
\text { Ferraz }\end{array}$ & \\
\hline 50 & 1958 & SETEMBRO/ OUTUBRO & $\begin{array}{l}\text { cargo } \\
\text { extinto }\end{array}$ & $\begin{array}{l}\text { Geraldo N. } \\
\text { Serra }\end{array}$ & $\begin{array}{l}\text { Rodolfo } \\
\text { Klein }\end{array}$ & $\begin{array}{l}\text { Geraldo N. } \\
\text { Serra }\end{array}$ & $\begin{array}{c}\text { José } \\
\text { Geraldo } \\
\text { Vieira }\end{array}$ & $\begin{array}{l}\text { Geraldo } \\
\text { Ferraz }\end{array}$ & \\
\hline 51 & 1958 & $\begin{array}{l}\text { NOVEMBRO/ } \\
\text { DEZEMBRO }\end{array}$ & $\begin{array}{l}\text { cargo } \\
\text { extinto }\end{array}$ & $\begin{array}{l}\text { Geraldo N. } \\
\text { Serra }\end{array}$ & $\begin{array}{l}\text { Rodolfo } \\
\text { Klein }\end{array}$ & $\begin{array}{l}\text { Geraldo N. } \\
\text { Serra }\end{array}$ & $\begin{array}{c}\text { José } \\
\text { Geraldo } \\
\text { Vieira }\end{array}$ & $\begin{array}{l}\text { Geraldo } \\
\text { Ferraz }\end{array}$ & \\
\hline 52 & 1959 & JANEIRO/ FEVEREIRO & $\begin{array}{l}\text { cargo } \\
\text { extinto }\end{array}$ & $\begin{array}{l}\text { Geraldo N. } \\
\text { Serra }\end{array}$ & $\begin{array}{l}\text { Rodolfo } \\
\text { Klein }\end{array}$ & $\begin{array}{l}\text { Geraldo N. } \\
\text { Serra }\end{array}$ & $\begin{array}{l}\text { José } \\
\text { Geraldo } \\
\text { Vieira }\end{array}$ & $\begin{array}{l}\text { Geraldo } \\
\text { Ferraz }\end{array}$ & \\
\hline 53 & 1959 & MARÇO/ ABRIL & $\begin{array}{l}\text { cargo } \\
\text { extinto }\end{array}$ & $\begin{array}{l}\text { Geraldo N. } \\
\text { Serra }\end{array}$ & $\begin{array}{l}\text { Rodolfo } \\
\text { Klein }\end{array}$ & $\begin{array}{l}\text { Geraldo N. } \\
\text { Serra }\end{array}$ & $\begin{array}{c}\text { José } \\
\text { Geraldo } \\
\text { Vieira }\end{array}$ & $\begin{array}{l}\text { Geraldo } \\
\text { Ferraz }\end{array}$ & \\
\hline 54 & 1959 & MAIO/ JUNHO & $\begin{array}{l}\text { cargo } \\
\text { extinto }\end{array}$ & $\begin{array}{l}\text { Geraldo N. } \\
\text { Serra }\end{array}$ & $\begin{array}{l}\text { Rodolfo } \\
\text { Klein }\end{array}$ & $\begin{array}{l}\text { Geraldo N. } \\
\text { Serra }\end{array}$ & $\begin{array}{l}\text { José } \\
\text { Geraldo } \\
\text { Vieira }\end{array}$ & $\begin{array}{l}\text { Geraldo } \\
\text { Ferraz }\end{array}$ & \\
\hline 55 & 1959 & JULHO/ AGOSTO & $\begin{array}{l}\text { cargo } \\
\text { extinto }\end{array}$ & $\begin{array}{l}\text { Geraldo N. } \\
\text { Serra }\end{array}$ & $\begin{array}{l}\text { Rodolfo } \\
\text { Klein }\end{array}$ & $\begin{array}{l}\text { Geraldo N. } \\
\text { Serra }\end{array}$ & $\begin{array}{c}\text { José } \\
\text { Geraldo } \\
\text { Vieira }\end{array}$ & $\begin{array}{l}\text { Geraldo } \\
\text { Ferraz }\end{array}$ & \\
\hline 56 & 1959 & SETEMBRO/ OUTUBRO & $\begin{array}{l}\text { cargo } \\
\text { extinto }\end{array}$ & $\begin{array}{l}\text { Geraldo N. } \\
\text { Serra }\end{array}$ & $\begin{array}{l}\text { Rodolfo } \\
\text { Klein }\end{array}$ & $\begin{array}{l}\text { Geraldo N. } \\
\text { Serra }\end{array}$ & $\begin{array}{l}\text { José } \\
\text { Geraldo } \\
\text { Vieira }\end{array}$ & $\begin{array}{l}\text { Geraldo } \\
\text { Ferraz }\end{array}$ & \\
\hline 57 & 1959 & $\begin{array}{l}\text { NOVEMBRO/ } \\
\text { DEZEMBRO }\end{array}$ & $\begin{array}{l}\text { cargo } \\
\text { extinto }\end{array}$ & $\begin{array}{l}\text { Geraldo N. } \\
\text { Serra }\end{array}$ & $\begin{array}{l}\text { Rodolfo } \\
\text { Klein }\end{array}$ & $\begin{array}{l}\text { Geraldo N. } \\
\text { Serra }\end{array}$ & $\begin{array}{c}\text { José } \\
\text { Geraldo } \\
\text { Vieira }\end{array}$ & $\begin{array}{l}\text { Geraldo } \\
\text { Ferraz }\end{array}$ & \\
\hline 58 & 1960 & JANEIRO/ FEVEREIRO & $\begin{array}{l}\text { cargo } \\
\text { extinto }\end{array}$ & $\begin{array}{l}\text { Geraldo N. } \\
\text { Serra }\end{array}$ & $\begin{array}{l}\text { Rodolfo } \\
\text { Klein }\end{array}$ & $\begin{array}{l}\text { Geraldo N. } \\
\text { Serra }\end{array}$ & $\begin{array}{c}\text { José } \\
\text { Geraldo } \\
\text { Vieira }\end{array}$ & $\begin{array}{l}\text { Geraldo } \\
\text { Ferraz }\end{array}$ & \\
\hline 59 & 1960 & MARÇO/ ABRIL & $\begin{array}{l}\text { cargo } \\
\text { extinto }\end{array}$ & $\begin{array}{l}\text { Geraldo N. } \\
\text { Serra }\end{array}$ & $\begin{array}{l}\text { Rodolfo } \\
\text { Klein }\end{array}$ & $\begin{array}{l}\text { Geraldo N. } \\
\text { Serra }\end{array}$ & $\begin{array}{l}\text { José } \\
\text { Geraldo } \\
\text { Vieira }\end{array}$ & $\begin{array}{l}\text { Geraldo } \\
\text { Ferraz }\end{array}$ & \\
\hline 60 & 1960 & MAIO/ JUNHO & $\begin{array}{l}\text { cargo } \\
\text { extinto }\end{array}$ & $\begin{array}{l}\text { Geraldo N. } \\
\text { Serra }\end{array}$ & $\begin{array}{l}\text { Rodolfo } \\
\text { Klein }\end{array}$ & $\begin{array}{l}\text { Geraldo N. } \\
\text { Serra }\end{array}$ & $\begin{array}{c}\text { José } \\
\text { Geraldo } \\
\text { Vieira }\end{array}$ & $\begin{array}{l}\text { Geraldo } \\
\text { Ferraz }\end{array}$ & \\
\hline 61 & 1960 & JULHO/ AGOSTO & $\begin{array}{l}\text { cargo } \\
\text { extinto }\end{array}$ & $\begin{array}{l}\text { Geraldo N. } \\
\text { Serra }\end{array}$ & $\begin{array}{l}\text { Rodolfo } \\
\text { Klein }\end{array}$ & $\begin{array}{l}\text { Geraldo N. } \\
\text { Serra }\end{array}$ & $\begin{array}{c}\text { José } \\
\text { Geraldo } \\
\text { Vieira }\end{array}$ & $\begin{array}{l}\text { Geraldo } \\
\text { Ferraz }\end{array}$ & \\
\hline
\end{tabular}




\begin{tabular}{|c|c|c|c|c|c|c|c|c|}
\hline 62 & 1960 & SETEMBRO/ OUTUBRO & $\begin{array}{l}\text { cargo } \\
\text { extinto }\end{array}$ & $\begin{array}{l}\text { Geraldo N. } \\
\text { Serra }\end{array}$ & $\begin{array}{l}\text { Rodolfo } \\
\text { Klein }\end{array}$ & $\begin{array}{l}\text { Geraldo N. } \\
\text { Serra }\end{array}$ & $\begin{array}{c}\text { José } \\
\text { Geraldo } \\
\text { Vieira }\end{array}$ & $\begin{array}{c}\text { Geraldo } \\
\text { Ferraz }\end{array}$ \\
\hline 63 & 1960 & $\begin{array}{l}\text { NOVEMBRO/ } \\
\text { DEZEMBRO }\end{array}$ & $\begin{array}{l}\text { cargo } \\
\text { extinto }\end{array}$ & $\begin{array}{l}\text { Geraldo N. } \\
\text { Serra }\end{array}$ & $\begin{array}{l}\text { Rodolfo } \\
\text { Klein }\end{array}$ & $\begin{array}{l}\text { Geraldo N. } \\
\text { Serra }\end{array}$ & $\begin{array}{c}\text { José } \\
\text { Geraldo } \\
\text { Vieira }\end{array}$ & $\begin{array}{c}\text { Geraldo } \\
\text { Ferraz }\end{array}$ \\
\hline 64 & 1961 & $\begin{array}{c}\text { JANEIRO/ FEVEREIRO/ } \\
\text { MARÇO }\end{array}$ & $\begin{array}{l}\text { cargo } \\
\text { extinto }\end{array}$ & $\begin{array}{l}\text { Geraldo N. } \\
\text { Serra }\end{array}$ & $\begin{array}{l}\text { Rodolfo } \\
\text { Klein }\end{array}$ & $\begin{array}{l}\text { Geraldo N. } \\
\text { Serra }\end{array}$ & $\begin{array}{c}\text { José } \\
\text { Geraldo } \\
\text { Vieira }\end{array}$ & $\begin{array}{c}\text { Geraldo } \\
\text { Ferraz }\end{array}$ \\
\hline 65 & 1961 & ABRIL/ MAIO/ JUNHO & $\begin{array}{l}\text { cargo } \\
\text { extinto }\end{array}$ & $\begin{array}{l}\text { Geraldo N. } \\
\text { Serra }\end{array}$ & $\begin{array}{l}\text { Rodolfo } \\
\text { Klein }\end{array}$ & $\begin{array}{l}\text { Geraldo N. } \\
\text { Serra }\end{array}$ & $\begin{array}{c}\text { José } \\
\text { Geraldo } \\
\text { Vieira }\end{array}$ & $\begin{array}{c}\text { Geraldo } \\
\text { Ferraz }\end{array}$ \\
\hline 66 & 1961 & $\begin{array}{c}\text { JULHO/ AGOSTO/ } \\
\text { SETEMBRO }\end{array}$ & $\begin{array}{l}\text { cargo } \\
\text { extinto }\end{array}$ & $\begin{array}{l}\text { Geraldo N. } \\
\text { Serra }\end{array}$ & $\begin{array}{l}\text { Rodolfo } \\
\text { Klein }\end{array}$ & $\begin{array}{l}\text { Geraldo N. } \\
\text { Serra }\end{array}$ & $\begin{array}{l}\text { José } \\
\text { Geraldo } \\
\text { Vieira }\end{array}$ & $\begin{array}{l}\text { Geraldo } \\
\text { Ferraz }\end{array}$ \\
\hline 67 & 1961 & $\begin{array}{c}\text { OUTUBRO/ } \\
\text { NOVEMBRO/ } \\
\text { DEZEMBRO } \\
\end{array}$ & $\begin{array}{l}\text { cargo } \\
\text { extinto }\end{array}$ & $\begin{array}{l}\text { Geraldo N. } \\
\text { Serra }\end{array}$ & $\begin{array}{l}\text { Rodolfo } \\
\text { Klein }\end{array}$ & $\begin{array}{l}\text { Geraldo N. } \\
\text { Serra }\end{array}$ & $\begin{array}{c}\text { José } \\
\text { Geraldo } \\
\text { Vieira }\end{array}$ & $\begin{array}{c}\text { Geraldo } \\
\text { Ferraz }\end{array}$ \\
\hline 68 & 1962 & $\begin{array}{c}\text { JANEIRO/ FEVEREIRO/ } \\
\text { MARÇO }\end{array}$ & $\begin{array}{l}\text { cargo } \\
\text { extinto }\end{array}$ & $\begin{array}{l}\text { Geraldo N. } \\
\text { Serra }\end{array}$ & $\begin{array}{l}\text { Rodolfo } \\
\text { Klein }\end{array}$ & $\begin{array}{l}\text { Geraldo N. } \\
\text { Serra }\end{array}$ & $\begin{array}{c}\text { José } \\
\text { Geraldo } \\
\text { Vieira }\end{array}$ & $\begin{array}{c}\text { Geraldo } \\
\text { Ferraz }\end{array}$ \\
\hline 69 & 1962 & ABRIL/ MAIO/ JUNHO & $\begin{array}{l}\text { cargo } \\
\text { extinto }\end{array}$ & $\begin{array}{l}\text { Geraldo N. } \\
\text { Serra }\end{array}$ & $\begin{array}{l}\text { Rodolfo } \\
\text { Klein }\end{array}$ & $\begin{array}{l}\text { Geraldo N. } \\
\text { Serra }\end{array}$ & $\begin{array}{c}\text { José } \\
\text { Geraldo } \\
\text { Vieira }\end{array}$ & $\begin{array}{c}\text { Geraldo } \\
\text { Ferraz }\end{array}$ \\
\hline 70 & 1962 & $\begin{array}{l}\text { JULHO/ AGOSTO/ } \\
\text { SETEMBRO }\end{array}$ & $\begin{array}{l}\text { cargo } \\
\text { extinto }\end{array}$ & $\begin{array}{l}\text { Geraldo N. } \\
\text { Serra }\end{array}$ & $\begin{array}{l}\text { Rodolfo } \\
\text { Klein }\end{array}$ & $\begin{array}{l}\text { Geraldo N. } \\
\text { Serra }\end{array}$ & $\begin{array}{c}\text { José } \\
\text { Geraldo } \\
\text { Vieira }\end{array}$ & $\begin{array}{c}\text { Geraldo } \\
\text { Ferraz }\end{array}$ \\
\hline 71 & 1962 & $\begin{array}{c}\text { OUTUBRO/ } \\
\text { NOVEMBRO/ } \\
\text { DEZEMBRO }\end{array}$ & $\begin{array}{l}\text { cargo } \\
\text { extinto }\end{array}$ & $\begin{array}{l}\text { Geraldo N. } \\
\text { Serra }\end{array}$ & $\begin{array}{l}\text { Rodolfo } \\
\text { Klein }\end{array}$ & $\begin{array}{l}\text { Geraldo N. } \\
\text { Serra }\end{array}$ & $\begin{array}{c}\text { José } \\
\text { Geraldo } \\
\text { Vieira }\end{array}$ & $\begin{array}{c}\text { Geraldo } \\
\text { Ferraz }\end{array}$ \\
\hline 72 & 1963 & $\begin{array}{c}\text { JANEIRO/ FEVEREIRO/ } \\
\text { MARÇO }\end{array}$ & $\begin{array}{l}\text { cargo } \\
\text { extinto }\end{array}$ & $\begin{array}{l}\text { Geraldo N. } \\
\text { Serra }\end{array}$ & $\begin{array}{l}\text { Rodolfo } \\
\text { Klein }\end{array}$ & $\begin{array}{l}\text { Geraldo N. } \\
\text { Serra }\end{array}$ & $\begin{array}{c}\text { José } \\
\text { Geraldo } \\
\text { Vieira }\end{array}$ & $\begin{array}{c}\text { Geraldo } \\
\text { Ferraz }\end{array}$ \\
\hline 73 & 1963 & ABRIL/ MAIO/ JUNHO & $\begin{array}{l}\text { cargo } \\
\text { extinto }\end{array}$ & $\begin{array}{l}\text { Geraldo N. } \\
\text { Serra }\end{array}$ & $\begin{array}{l}\text { Rodolfo } \\
\text { Klein }\end{array}$ & $\begin{array}{l}\text { Geraldo N. } \\
\text { Serra }\end{array}$ & $\begin{array}{c}\text { José } \\
\text { Geraldo } \\
\text { Vieira }\end{array}$ & $\begin{array}{c}\text { Geraldo } \\
\text { Ferraz }\end{array}$ \\
\hline 74 & 1963 & $\begin{array}{l}\text { JULHO/ AGOSTO/ } \\
\text { SETEMBRO }\end{array}$ & $\begin{array}{l}\text { cargo } \\
\text { extinto }\end{array}$ & $\begin{array}{l}\text { Geraldo N. } \\
\text { Serra }\end{array}$ & $\begin{array}{l}\text { Rodolfo } \\
\text { Klein }\end{array}$ & $\begin{array}{l}\text { Geraldo N. } \\
\text { Serra }\end{array}$ & $\begin{array}{c}\text { José } \\
\text { Geraldo } \\
\text { Vieira }\end{array}$ & $\begin{array}{c}\text { Geraldo } \\
\text { Ferraz }\end{array}$ \\
\hline 75 & 1963 & $\begin{array}{c}\text { OUTUBRO/ } \\
\text { NOVEMBRO/ } \\
\text { DEZEMBRO }\end{array}$ & $\begin{array}{l}\text { cargo } \\
\text { extinto }\end{array}$ & $\begin{array}{l}\text { Geraldo N. } \\
\text { Serra }\end{array}$ & $\begin{array}{l}\text { Rodolfo } \\
\text { Klein }\end{array}$ & $\begin{array}{l}\text { Geraldo N. } \\
\text { Serra }\end{array}$ & $\begin{array}{c}\text { José } \\
\text { Geraldo } \\
\text { Vieira }\end{array}$ & $\begin{array}{c}\text { Geraldo } \\
\text { Ferraz }\end{array}$ \\
\hline 76 & 1964 & $\begin{array}{c}\text { JANEIRO/ FEVEREIRO/ } \\
\text { MARÇO }\end{array}$ & $\begin{array}{l}\text { cargo } \\
\text { extinto }\end{array}$ & $\begin{array}{l}\text { Geraldo N. } \\
\text { Serra }\end{array}$ & $\begin{array}{l}\text { Rodolfo } \\
\text { Klein }\end{array}$ & $\begin{array}{l}\text { Geraldo N. } \\
\text { Serra }\end{array}$ & $\begin{array}{c}\text { José } \\
\text { Geraldo } \\
\text { Vieira }\end{array}$ & $\begin{array}{c}\text { Geraldo } \\
\text { Ferraz }\end{array}$ \\
\hline 77 & 1964 & ABRIL/ MAIO/ JUNHO & $\begin{array}{l}\text { cargo } \\
\text { extinto }\end{array}$ & $\begin{array}{l}\text { Geraldo N. } \\
\text { Serra }\end{array}$ & $\begin{array}{l}\text { Rodolfo } \\
\text { Klein }\end{array}$ & $\begin{array}{l}\text { Geraldo N. } \\
\text { Serra }\end{array}$ & $\begin{array}{c}\text { José } \\
\text { Geraldo } \\
\text { Vieira }\end{array}$ & $\begin{array}{c}\text { Geraldo } \\
\text { Ferraz }\end{array}$ \\
\hline 78 & 1964 & JULHO/ AGOSTO & $\begin{array}{l}\text { cargo } \\
\text { extinto }\end{array}$ & $\begin{array}{l}\text { Geraldo N. } \\
\text { Serra }\end{array}$ & $\begin{array}{l}\text { Rodolfo } \\
\text { Klein }\end{array}$ & $\begin{array}{l}\text { Geraldo N. } \\
\text { Serra }\end{array}$ & $\begin{array}{c}\text { José } \\
\text { Geraldo } \\
\text { Vieira }\end{array}$ & $\begin{array}{c}\text { Geraldo } \\
\text { Ferraz }\end{array}$ \\
\hline 79 & 1964 & SETEMBRO/ OUTUBRO & $\begin{array}{l}\text { cargo } \\
\text { extinto }\end{array}$ & $\begin{array}{l}\text { Geraldo N. } \\
\text { Serra }\end{array}$ & $\begin{array}{l}\text { Rodolfo } \\
\text { Klein }\end{array}$ & $\begin{array}{l}\text { Geraldo N. } \\
\text { Serra }\end{array}$ & $\begin{array}{l}\text { José } \\
\text { Geraldo } \\
\text { Vieira }\end{array}$ & $\begin{array}{c}\text { Geraldo } \\
\text { Ferraz }\end{array}$ \\
\hline 80 & 1964 & $\begin{array}{l}\text { NOVEMBRO/ } \\
\text { DEZEMBRO }\end{array}$ & $\begin{array}{l}\text { cargo } \\
\text { extinto }\end{array}$ & $\begin{array}{l}\text { Geraldo N. } \\
\text { Serra }\end{array}$ & $\begin{array}{l}\text { Rodolfo } \\
\text { Klein }\end{array}$ & $\begin{array}{l}\text { Geraldo N. } \\
\text { Serra }\end{array}$ & $\begin{array}{l}\text { José } \\
\text { Geraldo } \\
\text { Vieira }\end{array}$ & $\begin{array}{c}\text { Geraldo } \\
\text { Ferraz }\end{array}$ \\
\hline 81 & 1965 & JANEIRO/ FEVEREIRO & $\begin{array}{l}\text { cargo } \\
\text { extinto }\end{array}$ & $\begin{array}{l}\text { Geraldo N. } \\
\text { Serra }\end{array}$ & $\begin{array}{l}\text { Rodolfo } \\
\text { Klein }\end{array}$ & $\begin{array}{l}\text { Geraldo N. } \\
\text { Serra }\end{array}$ & $\begin{array}{l}\text { José } \\
\text { Geraldo } \\
\text { Vieira }\end{array}$ & $\begin{array}{c}\text { Geraldo } \\
\text { Ferraz }\end{array}$ \\
\hline 82 & 1965 & MARÇO/ ABRIL & $\begin{array}{l}\text { cargo } \\
\text { extinto }\end{array}$ & $\begin{array}{l}\text { Geraldo N. } \\
\text { Serra }\end{array}$ & $\begin{array}{l}\text { Rodolfo } \\
\text { Klein }\end{array}$ & $\begin{array}{l}\text { Geraldo N. } \\
\text { Serra }\end{array}$ & $\begin{array}{l}\text { José } \\
\text { Geraldo } \\
\text { Vieira }\end{array}$ & $\begin{array}{c}\text { Geraldo } \\
\text { Ferraz }\end{array}$ \\
\hline 83 & 1965 & MAIO/ JUNHO & $\begin{array}{l}\text { cargo } \\
\text { extinto }\end{array}$ & $\begin{array}{l}\text { Geraldo N. } \\
\text { Serra }\end{array}$ & $\begin{array}{l}\text { Rodolfo } \\
\text { Klein }\end{array}$ & $\begin{array}{l}\text { Geraldo N. } \\
\text { Serra }\end{array}$ & $\begin{array}{c}\text { José } \\
\text { Geraldo } \\
\text { Vieira }\end{array}$ & $\begin{array}{c}\text { Geraldo } \\
\text { Ferraz }\end{array}$ \\
\hline 84 & 1965 & $\begin{array}{c}\text { JULHO/ AGOSTO/ } \\
\text { SETEMBRO/ OUTUBRO/ } \\
\text { NOVEM/ DEZEMBRO }\end{array}$ & $\begin{array}{l}\text { cargo } \\
\text { extinto }\end{array}$ & $\begin{array}{l}\text { Geraldo N. } \\
\text { Serra }\end{array}$ & $\begin{array}{l}\text { Rodolfo } \\
\text { Klein }\end{array}$ & $\begin{array}{l}\text { Geraldo N. } \\
\text { Serra }\end{array}$ & $\begin{array}{l}\text { José } \\
\text { Geraldo } \\
\text { Vieira }\end{array}$ & $\begin{array}{c}\text { Geraldo } \\
\text { Ferraz }\end{array}$ \\
\hline
\end{tabular}


ÍNDICE CLASSIFICADO E COMENTADO

\begin{tabular}{|c|c|c|c|c|c|c|c|}
\hline TEMA & AUTOR & TíTULO & DESCRIÇÃO & HABITAT & PÁG. & DATA & DESCRIÇÃO \\
\hline editorial & $\begin{array}{l}\text { Lina Bo Bardi } \\
\text { (?) }\end{array}$ & "Prefácio" & $\begin{array}{l}\text { os compromissos à que a } \\
\text { Revista Habitat se propõe }\end{array}$ & 1 & 1 & $\begin{array}{l}1950 \text { OUT/NOV/ } \\
\text { DEZ }\end{array}$ & Lina Bo Bardi \\
\hline arquitetura & Lina Bo Bardi & "Casas de Artigas" & 4 residências em São Paulo & 1 & 2 & $\begin{array}{c}1950 \text { OUT/NOV/ } \\
\text { DEZ }\end{array}$ & Lina Bo Bardi \\
\hline museus & Lina Bo Bardi & "A Função social dos Museus" & $\begin{array}{l}\text { papel didático do MASP/ criação } \\
\text { do IAC }\end{array}$ & 1 & 17 & $\begin{array}{c}1950 \text { OUT/NOV/ } \\
\text { DEZ }\end{array}$ & Lina Bo Bardi \\
\hline museus & $\begin{array}{c}\text { Nelson } \\
\text { Rockefeller }\end{array}$ & "Cidadelas da civilização" & $\begin{array}{c}0 \text { artigo transcreve o discurso. } \\
\text { do Sr. Nelson Rockefeller por } \\
\text { ocasião da inauguração do } \\
\text { Museu de Arte }\end{array}$ & 1 & 18 & $\begin{array}{l}1951 \text { OUT/NOV/ } \\
\text { DEZ }\end{array}$ & Lina Bo Bardi \\
\hline arquitetura & sem autoria & "Sinopse do Museu de Arte" & $\begin{array}{l}\text { descritivo - projeto sede para a } \\
\text { sede na } 7 \text { de abril }\end{array}$ & 1 & 20 & $\begin{array}{c}1950 \text { OUT/NOV/ } \\
\text { DEZ }\end{array}$ & Lina Bo Bardi \\
\hline museus & sem autoria & "Vitrina das formas" & $\begin{array}{l}\text { subtema do artigo "Sinopse do } \\
\text { Museu de Arte" }\end{array}$ & 1 & 35 & $\begin{array}{c}1950 \text { OUT/NOV/ } \\
\text { DEZ }\end{array}$ & Lina Bo Bardi \\
\hline arquitetura & sem autoria & $\begin{array}{l}\text { "Novo Mundo do Espaço" de Le } \\
\text { Corbusier }\end{array}$ & $\begin{array}{l}\text { divulgação - exposição - } \\
\text { modulor }\end{array}$ & 1 & 37 & $\begin{array}{c}1950 \text { OUT/NOV/ } \\
\text { DEZ }\end{array}$ & Lina Bo Bardi \\
\hline museus & sem autoria & “0 acervo da Pinacoteca’ & $\begin{array}{l}\text { apresentação do acervo do } \\
\text { Museu de Arte, através de } \\
\text { imagens, e uma extensa lista } \\
\text { com os nomes dos doadores }\end{array}$ & 1 & 41 & $\begin{array}{l}1950 \text { OUT/NOV/ } \\
\text { DEZ }\end{array}$ & Lina Bo Bardi \\
\hline museus & sem autoria & "A criança no Museu" & $\begin{array}{l}\text { divulgação das atividades do } \\
\text { Clube Infantil de Arte }\end{array}$ & 1 & 50 & $\begin{array}{c}1950 \text { OUT/NOV/ } \\
\text { DEZ }\end{array}$ & Lina Bo Bardi \\
\hline $\begin{array}{l}\text { desenho } \\
\text { industrial }\end{array}$ & Frei Lodoli & "Frei Lodoli e a cadeira" & $\begin{array}{l}\text { documento tido como uma } \\
\text { profecia da arquitetura racional }\end{array}$ & 1 & 52 & $\begin{array}{c}1950 \text { OUT/NOV/ } \\
\text { DEZ }\end{array}$ & Lina Bo Bardi \\
\hline $\begin{array}{l}\text { desenho } \\
\text { industrial }\end{array}$ & $\begin{array}{l}\text { Lina Bo Bardi e } \\
\text { Palanti }\end{array}$ & "Móveis novos" & $\begin{array}{l}\text { "Cadeiras" (índice) - Studio de } \\
\text { Arte Palma }\end{array}$ & 1 & 53 & $\begin{array}{c}1950 \text { OUT/NOV/ } \\
\text { DEZ }\end{array}$ & Lina Bo Bardi \\
\hline arte & sem autoria & $\begin{array}{c}\text { "Os vasos de barro de Elizabeth } \\
\text { Nobilling" }\end{array}$ & o bom desenho & 1 & 60 & $\begin{array}{c}1950 \text { OUT/NOV/ } \\
\text { DEZ }\end{array}$ & Lina Bo Bardi \\
\hline arte & sem autoria & "Os tecidos de Clara Hartoch" & $\begin{array}{l}\text { artista formada na Bauhaus - } \\
\text { tecidos feito à mão }\end{array}$ & 1 & 61 & $\begin{array}{c}1950 \text { OUT/NOV/ } \\
\text { DEZ }\end{array}$ & Lina Bo Bardi \\
\hline arte & sem autoria & "Tecidos de A. M. Fiocca" & $\begin{array}{l}0 \text { correto uso da cor e do } \\
\text { algodão }\end{array}$ & 1 & 62 & $\begin{array}{c}1950 \text { OUT/NOV/ } \\
\text { DEZ }\end{array}$ & Lina Bo Bardi \\
\hline $\begin{array}{l}\text { desenho } \\
\text { industrial }\end{array}$ & sem autoria & "0 sizal" & utilização do sizal na industria & 1 & 63 & $\begin{array}{c}1950 \text { OUT/NOV/ } \\
\text { DEZ }\end{array}$ & Lina Bo Bardi \\
\hline fotografia & sem autoria & "Fotografias" & $\begin{array}{l}\text { fotografia documental de } \\
\text { Geraldo de Barros }\end{array}$ & 1 & 64 & $\begin{array}{c}1950 \text { OUT/NOV/ } \\
\text { DEZ }\end{array}$ & Lina Bo Bardi \\
\hline urbanismo & sem autoria & $\begin{array}{l}\text { "Do pequeno ao grande, numa } \\
\text { corrida" }\end{array}$ & $\begin{array}{l}\text { crescimento de São Paulo pede } \\
\text { plano urbanístico }\end{array}$ & 1 & 65 & $\begin{array}{c}1950 \text { OUT/NOV/ } \\
\text { DEZ }\end{array}$ & Lina Bo Bardi \\
\hline artesanato & sem autoria & "0 índio desenhista" & arte, geometrismo & 1 & 66 & $\begin{array}{c}1950 \text { OUT/NOV/ } \\
\text { DEZ }\end{array}$ & Lina Bo Bardi \\
\hline artesanato & sem autoria & "0 índio modista" & arte, indumentárias e enfeites & 1 & 67 & $\begin{array}{c}1950 \text { OUT/NOV/ } \\
\text { DEZ }\end{array}$ & Lina Bo Bardi \\
\hline arquitetura & $\begin{array}{l}\text { atribuido a Lina } \\
\text { Bo Bardi }\end{array}$ & "Amazonas: o povo arquiteto" & sabedoria popular & 1 & 68 & $\begin{array}{c}1950 \text { OUT/NOV/ } \\
\text { DEZ }\end{array}$ & Lina Bo Bardi \\
\hline artesanato & sem autoria & "Ex-votos do nordeste" & artista improvisado & 1 & 72 & $\begin{array}{c}1950 \text { OUT/NOV/ } \\
\text { DEZ }\end{array}$ & Lina Bo Bardi \\
\hline arquitetura & Flavio Motta & $\begin{array}{l}\text { "Um Museu do estilo floreal em } \\
\text { São Paulo" }\end{array}$ & $\begin{array}{c}\text { denuncia de demolição de casa } \\
\text { na rua Marques de Itu }\end{array}$ & 1 & 73 & $\begin{array}{c}1950 \text { OUT/NOV/ } \\
\text { DEZ }\end{array}$ & Lina Bo Bardi \\
\hline arte & $\begin{array}{l}\text { Wolfgang } \\
\text { Pfeiffer }\end{array}$ & $\begin{array}{l}\text { "Documentos inéditos da arte } \\
\text { brasileira" }\end{array}$ & $\begin{array}{l}2 \text { cartas de E. de Fiori à Sérgio } \\
\text { Milliet e } 1 \text { de M. Andrade à } \\
\text { Segall }\end{array}$ & 1 & 77 & $\begin{array}{l}1950 \text { OUT/NOV/ } \\
\text { DEZ }\end{array}$ & Lina Bo Bardi \\
\hline arquitetura & $\begin{array}{l}\text { Pietro Maria } \\
\text { Bardi }\end{array}$ & $\begin{array}{l}\text { "Problemas do Barroco: a } \\
\text { religião e a curva" }\end{array}$ & $\begin{array}{l}\text { da arquitetura barroca até a } \\
\text { racionalista passando por Lodoli }\end{array}$ & 1 & 80 & $\begin{array}{c}1950 \text { OUT/NOV/ } \\
\text { DEZ }\end{array}$ & Lina Bo Bardi \\
\hline música & $\begin{array}{c}\text { Antônio Rangel } \\
\text { Bandeira }\end{array}$ & $\begin{array}{c}\text { "Nossas raízes folclóricas e } \\
\text { populares" }\end{array}$ & panorama da música brasileira & 1 & 85 & $\begin{array}{c}1950 \text { OUT/NOV/ } \\
\text { DEZ }\end{array}$ & Lina Bo Bardi \\
\hline cinema & $\begin{array}{l}\text { Alberto } \\
\text { Cavalcanti }\end{array}$ & "Primeiros passos" & $\begin{array}{c}\text { desenvolvimento do cinema } \\
\text { nacional - Vera Cruz/falta apoio } \\
\text { governamental }\end{array}$ & 1 & 86 & $\begin{array}{c}1950 \text { OUT/NOV/ } \\
\text { DEZ }\end{array}$ & Lina Bo Bardi \\
\hline teatro & Ruggero Jacobbi & "Sete temas" & $\begin{array}{c}\text { repertório, público, teatros, } \\
\text { atores, diretor, cenógrafos, } \\
\text { críticos }\end{array}$ & 1 & 88 & $\begin{array}{c}1950 \text { OUT/NOV/ } \\
\text { DEZ }\end{array}$ & Lina Bo Bardi \\
\hline bailado & Nicanor Miranda & "Situação atual" & $\begin{array}{c}\text { dificuldades } \mathrm{p} / \mathrm{0} \\
\text { desenvolvimento do bailado no } \\
\text { Brasil }\end{array}$ & 1 & 89 & $\begin{array}{c}1950 \text { OUT/NOV/ } \\
\text { DEZ }\end{array}$ & Lina Bo Bardi \\
\hline
\end{tabular}


ÍNDICE CLASSIFICADO E COMENTADO

\begin{tabular}{|c|c|c|c|c|c|c|c|}
\hline TEMA & AUTOR & TÍTULO & DESCRIÇÃO & HABITAT & PÁG. & DATA & DESCRIÇÃO \\
\hline editorial & $\begin{array}{l}\text { Pietro Maria } \\
\text { Bardi }\end{array}$ & $\begin{array}{l}\text { "Para uma nova cultura do } \\
\text { homem" }\end{array}$ & $\begin{array}{l}\text { sobre o papel educativo a } \\
\text { que os museus devem se } \\
\text { comprometer e que a Unesco } \\
\text { recomenda em relatório }\end{array}$ & 2 & 1 & 1951 JAN/MAR & Lina Bo Bardi \\
\hline arquitetura & Lina Bo Bardi & "Bela criança" & $\begin{array}{l}\text { crítica ao risco de a arq. } \\
\text { Moderna transformar-se em } \\
\text { "academicismo" }\end{array}$ & 2 & 3 & 1951 JAN/MAR & Lina Bo Bardi \\
\hline arquitetura & $\begin{array}{l}\text { Abelardo de } \\
\text { Souza }\end{array}$ & "Nossa arquitetura" & $\begin{array}{l}\text { análise do caminho próprio } \\
\text { tomado pela arq. Brasileira } \\
\text { e a impotência diante dos } \\
\text { problemas urbanos }\end{array}$ & 2 & 4 & 1951 JAN/MAR & Lina Bo Bardi \\
\hline arquitetura & Lina Bo Bardi & $\begin{array}{l}\text { "Duas construções de Oscar } \\
\text { Niemeyer" }\end{array}$ & $\begin{array}{l}\text { Fábrica Duchen - possibilidades } \\
\text { plásticas do concreto e } \\
\text { Edifício(R. Barão de Itapetininga) } \\
\text { p/ escritórios e comércio }\end{array}$ & 2 & 6 & 1951 JAN/MAR & Lina Bo Bardi \\
\hline arquitetura & $\begin{array}{l}\text { Abelardo de } \\
\text { Souza }\end{array}$ & $\begin{array}{l}\text { "Projeto de Piscina de Abelardo } \\
\text { de Souza" }\end{array}$ & descritivo + peças gráficas & 2 & 12 & 1951 JAN/MAR & Lina Bo Bardi \\
\hline urbanismo & $\begin{array}{l}\text { Abelardo de } \\
\text { Souza }\end{array}$ & $\begin{array}{l}\text { "Programa de melhoramentos } \\
\text { para São Paulo" }\end{array}$ & $\begin{array}{l}\text { crítica a contratação pelo poder } \\
\text { público de técnicos urbanistas } \\
\text { americanos (Robert Moses) p/ } \\
\text { São Paulo }\end{array}$ & 2 & 14 & 1951 JAN/MAR & Lina Bo Bardi \\
\hline urbanismo & $\begin{array}{l}\text { Abelardo de } \\
\text { Souza }\end{array}$ & "Planos" & $\begin{array}{c}\text { sobre a nova capital - a } \\
\text { necessidade de um plano } \\
\text { nacional (não apenas local), de } \\
\text { olhar para o futuro e de haver } \\
\text { participação da comunidade }\end{array}$ & 2 & 15 & 1951 JAN/MAR & Lina Bo Bardi \\
\hline arquitetura & $\begin{array}{l}\text { Icaro de Castro } \\
\text { e Melo }\end{array}$ & $\begin{array}{l}\text { "Um gymnasium de Icaro de } \\
\text { Castro Melo" }\end{array}$ & $\begin{array}{c}\text { maior do estado de S.P. } \\
\text { descritivo + peças gráficas }\end{array}$ & 2 & 16 & 1951 JAN/MAR & Lina Bo Bardi \\
\hline arquitetura & $\begin{array}{c}\text { Gregori } \\
\text { Warchavchik }\end{array}$ & $\begin{array}{c}\text { "Uma casa no Guarujá de } \\
\text { Gregori Warchavchik" }\end{array}$ & descritivo + peças gráficas & 2 & 17 & 1951 JAN/MAR & Lina Bo Bardi \\
\hline arquitetura & Rino Levi & $\begin{array}{l}\text { "Residência em São José dos } \\
\text { Campos de Rino Levi" }\end{array}$ & $\begin{array}{l}\text { descritivo + peças gráficas } \\
\text { (detalhamento) }\end{array}$ & 2 & 19 & 1951 JAN/MAR & Lina Bo Bardi \\
\hline arte & Mario Yahn & "Pintores sem saber" & $\begin{array}{c}\text { análise da obra de José } \\
\text { Theophilo, interno do Juqueri }\end{array}$ & 2 & 27 & 1951 JAN/MAR & Lina Bo Bardi \\
\hline $\begin{array}{l}\text { arquitetura/ } \\
\text { interiores }\end{array}$ & Lina Bo Bardi & "Um restaurante" & $\begin{array}{l}\text { restaurante "Prato de Ouro"- } \\
\text { projeto de interiores de Lina } \\
\text { (imagens) }\end{array}$ & 2 & 28 & 1951 JAN/MAR & Lina Bo Bardi \\
\hline $\begin{array}{l}\text { desenho } \\
\text { industrial }\end{array}$ & G. C. Palanti & "Estantes para livros" & $\begin{array}{l}\text { estante em madeira modulada, } \\
\text { desenho de Palanti }\end{array}$ & 2 & 32 & 1951 JAN/MAR & Lina Bo Bardi \\
\hline arte & sem autoria & "Saul Steinberg" & $\begin{array}{c}\text { divulgação do desenhista que } \\
\text { deverá ter obra exposta no } \\
\text { Museu }\end{array}$ & 2 & 34 & 1951 JAN/MAR & Lina Bo Bardi \\
\hline museus & $\begin{array}{l}\text { Wolfgang } \\
\text { Pfeiffer }\end{array}$ & "Pinacoteca do Museu de Arte" & $\begin{array}{c}\text { texto que apresenta as } \\
\text { aquisições da pinacoteca } \\
\text { (seguido por uma série de } \\
\text { textos) e ressalta a freqüência } \\
\text { popular no Museu }\end{array}$ & 2 & 35 & 1951 JAN/MAR & Lina Bo Bardi \\
\hline arquitetura & sem autoria & "Uma exposição" & $\begin{array}{l}\text { exposição agrícula-projeto de } \\
\text { artistas e arquitetos (Jacob } \\
\text { Ruchti, Leopold Haar e Gezá } \\
\text { Kaufmann) }\end{array}$ & 2 & 42 & 1951 JAN/MAR & Lina Bo Bardi \\
\hline propaganda & sem autoria & "Salão de propaganda" & $\begin{array}{l}\text { a importância do primeira salão, } \\
\text { sediado no Museu }\end{array}$ & 2 & 44 & 1951 JAN/MAR & Lina Bo Bardi \\
\hline arquitetura & sem autoria & "Documentos da arte brasileira" & $\begin{array}{c}\text { manifesto de Warchavchik } \\
\text { "Acerca da arquitetura moderna" } \\
\text { de } 1925\end{array}$ & 2 & 51 & 1951 JAN/MAR & Lina Bo Bardi \\
\hline museus & $\begin{array}{c}\text { Assis } \\
\text { Chateaubriand }\end{array}$ & "Agora, ou nunca mais" & $\begin{array}{l}\text { necessidade de investimento } \\
\text { para ganhar o mercado de artes } \\
\text { plásticas na Europa }\end{array}$ & 2 & $\begin{array}{l}51 \mathrm{~s} / \\
\text { número }\end{array}$ & 1951 JAN/MAR & Lina Bo Bardi \\
\hline arquitetura & Roger Bastide & "Variations sur la porte baroque" & $\begin{array}{c}\text { traduzir - segue ilustrações de } \\
\text { obras religiosas na Bahia }\end{array}$ & 2 & 53 & 1951 JAN/MAR & Lina Bo Bardi \\
\hline arquitetura & sem autoria & "Velho São Paulo" & $\begin{array}{c}\text { três imagens de épocas } \\
\text { diferentes da formação de São } \\
\text { Paulo }\end{array}$ & 2 & 60 & 1951 JAN/MAR & Lina Bo Bardi \\
\hline
\end{tabular}


ÍNDICE CLASSIFICADO E COMENTADO

\begin{tabular}{|c|c|c|c|c|c|c|c|}
\hline TEMA & AUTOR & TÍTULO & DESCRIÇÃO & HABITA & T PÁG. & DATA & DESCRIÇÃO \\
\hline arte & Alen(castro?) & "Diálogo" & $\begin{array}{l}\text { conversa "fictícia" entre a } \\
\text { senhora, o crítico de arte e a } \\
\text { serpente. }\end{array}$ & 2 & $\begin{array}{l}60 \mathrm{~s} / \\
\text { número }\end{array}$ & 1951 JAN/MAR & Lina Bo Bardi \\
\hline arquitetura & Max Bill & $\begin{array}{l}\text { "Beleza provinda da funçãa e } \\
\text { beleza como função" }\end{array}$ & $\begin{array}{l}\text { sobre a responsabilidade a } \\
\text { cerca da forma }\end{array}$ & 2 & 61 & 1951 JAN/MAR & Lina Bo Bardi \\
\hline fotografia & sem autoria & "Convite a fotografar" & $\begin{array}{l}\text { o papel da fotografia como } \\
\text { polemista, documentarista } \\
\text { (fotos-P.M. e L.B. Bardi) }\end{array}$ & 2 & 66 & 1951 JAN/MAR & Lina Bo Bardi \\
\hline arte & sem autoria & "Mais um pintor primitivo" & $\begin{array}{c}\text { sobre Cassio M'Boy (exposição } \\
\text { no MASP) }\end{array}$ & 2 & 70 & 1951 JAN/MAR & Lina Bo Bardi \\
\hline artesanato & sem autoria & "Cerâmica do nordeste" & $\begin{array}{c}\text { como real manifestação } \\
\text { artística do povo brasileiro } \\
\text {-imagens de pequenos objetos } \\
\text { cerâmicos }\end{array}$ & 2 & 72 & 1951 JAN/MAR & Lina Bo Bardi \\
\hline museus & sem autoria & "Curso de Gravura" & $\begin{array}{c}\text { divulgação do curso em início } \\
\text { no MASP }\end{array}$ & 2 & 77 & 1951 JAN/MAR & Lina Bo Bardi \\
\hline arte & sem autoria & "Fayga Ostrower" & $\begin{array}{l}\text { exaltação da técnica da } \\
\text { gravurista }\end{array}$ & 2 & 78 & 1951 JAN/MAR & Lina Bo Bardi \\
\hline arte & sem autoria & "Tecidos de Burle-Marx" & $\begin{array}{l}\text { imagens de estampas em tecido } \\
\text { de Burle Marx }\end{array}$ & 2 & 79 & 1951 JAN/MAR & Lina Bo Bardi \\
\hline moda & sem autoria & "Um desfile" & $\begin{array}{l}\text { como uma exposição de arte } \\
\text { - promovido pelo MASP }\end{array}$ & 2 & 80 & 1951 JAN/MAR & Lina Bo Bardi \\
\hline cinema & $\begin{array}{l}\text { Florentino } \\
\text { Barbosa }\end{array}$ & “Um seminário" & $\begin{array}{c}\text { sobre o I Seminário de } \\
\text { Cinema, inaugurado em } 49 \\
\text { - MASP+Centro de Estudos } \\
\text { Cinematográficos }\end{array}$ & 2 & 82 & 1951 JAN/MAR & Lina Bo Bardi \\
\hline teatro & M. Askanasy & "Folclore brasileiro" & $\begin{array}{l}\text { origens do Primeiro Teatro } \\
\text { Folclórico Brasileiro", com } \\
\text { objetivo de resgatar "Famosos } \\
\text { autos folclóricos" e dar } \\
\text { oportunidade "a essa gente de } \\
\text { cor". }\end{array}$ & 2 & 84 & 1951 JAN/MAR & Lina Bo Bardi \\
\hline editorial & $\begin{array}{l}\text { Renato Cirell } \\
\text { Czerna }\end{array}$ & "Carta aberta" & $\begin{array}{c}\text { ao Governador-reestruturação } \\
\text { da cultura, ainda tida como } \\
\text { política do "panen et circenses" }\end{array}$ & 3 & 1 & 1951 ABR/JUN & Lina Bo Bardi \\
\hline arquitetura & $\begin{array}{l}\text { atribuído a Lina } \\
\text { Bo Bardi }\end{array}$ & "Porque o povo é arquiteto?" & $\begin{array}{l}\text { devido a simplicidade, a } \\
\text { racionalidade e a "construtura } \\
\text { lógica" presentes em suas } \\
\text { construções" }\end{array}$ & 3 & 3 & 1951 ABR/JUN & Lina Bo Bardi \\
\hline arquitetura & $\begin{array}{l}\text { atribuído a Lina } \\
\text { Bo Bardi }\end{array}$ & "Casa de 7 mil cruzeiros" & $\begin{array}{c}\text { demonstração da sabedoria do } \\
\text { povo arquiteto através de visita a } \\
\text { casa de uma operária }\end{array}$ & 3 & 4 & 1951 ABR/JUN & Lina Bo Bardi \\
\hline arquitetura & sem autoria & "Janelas" & $\begin{array}{l}\text { os diversos valores expressos } \\
\text { pelas janelas }+ \text { conjunto de } \\
\text { fotografias }\end{array}$ & 3 & 6 & 1951 ABR/JUN & Lina Bo Bardi \\
\hline arquitetura & $\begin{array}{l}\text { Pietro Maria } \\
\text { Bardi }\end{array}$ & "Os jardins de Burle Marx" & $\begin{array}{c}\text { exaltação da obra, crítica aos } \\
\text { painêis e pedido p/ inclusão } \\
\text { da escultura em seus jardins } \\
\text { (imagens dos jardins + projetos) }\end{array}$ & 3 & 7 & 1951 ABR/JUN & Lina Bo Bardi \\
\hline arquitetura & $\begin{array}{l}\text { atribuído a } \\
\text { Pietro Maria } \\
\text { Bardi }\end{array}$ & "Nervi e o concreto" & $\begin{array}{l}\text { sobre a palestra de Nervi no } \\
\text { Museu, sua obra e a "profecia" } \\
\text { do concreto no Brasil }\end{array}$ & 3 & 16 & 1951 ABR/JUN & Lina Bo Bardi \\
\hline arquitetura & P. L. Nervi & "Resistência de forma" & $\begin{array}{c}\text { sobre as infinitas possibilidades } \\
\text { do concreto e a complexidade } \\
\text { das estruturas resistentes 'pela } \\
\text { forma' }\end{array}$ & 3 & 17 & 1951 ABR/JUN & Lina Bo Bardi \\
\hline arquitetura & G. C. Palanti & "Edifício em São Paulo" & $\begin{array}{l}\text { descritivo do edifício de uso } \\
\text { misto (comércio e escritório) } \\
\text { do arq. Palanti, a Rua Florêncio } \\
\text { de Abreu. }\end{array}$ & 3 & 23 & 1951 ABR/JUN & Lina Bo Bardi \\
\hline arquitetura & G. C. Fongaro & "Interior de um clube" & $\begin{array}{l}\text { descritivo do projeto de G. } \\
\text { C. Fongaro para o Clube dos } \\
\text { Artistas de São Paulo. }\end{array}$ & 3 & 25 & 1951 ABR/JUN & Lina Bo Bardi \\
\hline arquitetura & sem autoria & "Habitat 4 dedicada às escolas" & $\begin{array}{l}\text { divulgação do tema a que o } \\
\text { próximo número será dedicado: } \\
\text { trabalho do Convênio Escolar }\end{array}$ & 3 & 29 & 1951 ABR/JUN & Lina Bo Bardi \\
\hline
\end{tabular}


ÍNDICE CLASSIFICADO E COMENTADO

\begin{tabular}{|c|c|c|c|c|c|c|c|}
\hline TEMA & AUTOR & TÍTULO & DESCRIÇÃO & HABITAT & PÁG. & DATA & DESCRIÇÃO \\
\hline arte & Geraldo Ferraz & "Reportagem do Recife" & $\begin{array}{l}\text { a transformação do Recife, pelo } \\
\text { desaparecimento da cidade do } \\
\text { séc. XVIII sob uma arquitetura } \\
\text { desqualificada, onde aparecem } \\
\text { os painéis murais de Cícero } \\
\text { Dias e o descuido do Serviço } \\
\text { do Patrimônio Artístico com a } \\
\text { arte sacra. } \\
\text { arte }\end{array}$ & 3 & 30 & 1951 ABR/JUN & Lina Bo Bardi \\
\hline artesanato & sem autoria & "Folhetos" & $\begin{array}{l}\text { sobre a arte popular dos } \\
\text { gravadores que trabalham } \\
\text { sobre a madeira, os temas dos } \\
\text { folhetos de poesia vendidos no } \\
\text { Norte }\end{array}$ & 3 & 36 & 1951 ABR/JUN & Lina Bo Bardi \\
\hline arte & sem autoria & "Inéditos de Ender" & 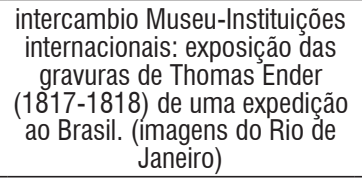 & 3 & 37 & 1951 ABR/JUN & Lina Bo Bardi \\
\hline moda & sem autoria & "Um instituto de costumes" & $\begin{array}{c}\text { a secção de costumes } \\
\text { do Museu segue o Centro } \\
\text { Internacional de Costumes } \\
\text { de Veneza. Atenção ao ponto } \\
\text { de contacto entre a arte e a } \\
\text { indústria } \\
\end{array}$ & 3 & 45 & 1952 ABR/JUN & Lina Bo Bardi \\
\hline arte & sem autoria & “Mundos desaparecidos' & $\begin{array}{l}\text { a importância da pesquisa } \\
\text { arqueológica à ser feita na } \\
\text { América e no Brasil (imagens de } \\
\text { cerâmicas Marajós e Maracá) }\end{array}$ & 3 & 48 & 1951 ABR/JUN & \\
\hline arquitetura & $\begin{array}{l}\text { J. F. de Almeida } \\
\text { Prado }\end{array}$ & $\begin{array}{c}\text { "Arquitetos de São Paulo em } \\
1880 "\end{array}$ & $\begin{array}{l}\text { livro de } 1880 \text {, descreve a } \\
\text { transformação da cidade de São } \\
\text { Paulo fruto da economia cafeeira } \\
\text { (imagens das construções } \\
\text { remanescentes do período) }\end{array}$ & 3 & 50 & 1951 ABR/JUN & Lina Bo Bardi \\
\hline arquitetura & sem autoria & "Arquitetura a banquete" & $\begin{array}{c}\text { sobre o mau gosto reinante nas } \\
\text { feiras internacionais. exposição } \\
\text { de arquitetura "Chantilly" } \\
\text { (imagens de registros de um } \\
\text { colecionador) }\end{array}$ & 3 & 54 & 1951 ABR/JUN & Lina Bo Bardi \\
\hline arquitetura & Rado & "Detalhes 1910" & $\begin{array}{l}\text { imagens de Rado - detalhes de } \\
\text { gradis e portais. }\end{array}$ & 3 & 58 & 1951 ABR/JUN & Lina Bo Bardi \\
\hline arte & sem autoria & "Cardoso Ayres e a caricatura" & $\begin{array}{l}\text { a crítica a sociedade burguesa } \\
\text { na obra de Ayres. Doação ao } \\
\text { Museu de álbum do cartunista } \\
\text { pela família. }\end{array}$ & 3 & 59 & 1951 ABR/JUN & Lina Bo Bardi \\
\hline arte & sem autoria & "Figurinhas" & $\begin{array}{l}\text { as imagens publicitárias como } \\
\text { material de pesquisa, retrato da } \\
\text { sociedade }\end{array}$ & 3 & 60 & 1951 ABR/JUN & Lina Bo Bardi \\
\hline $\begin{array}{l}\text { desenho } \\
\text { industrial }\end{array}$ & Jacob Ruchti & $\begin{array}{l}\text { "Instituto de Arte } \\
\text { Contemporânea" }\end{array}$ & $\begin{array}{c}\text { a inauguração do Instituto e } \\
\text { sua finalidade, importância e } \\
\text { estrutura curricular }\end{array}$ & 3 & 62 & 1951 ABR/JUN & Lina Bo Bardi \\
\hline museus & $\begin{array}{l}\text { Wolfgang } \\
\text { Pfeiffer }\end{array}$ & $\begin{array}{l}\text { "A pinacoteca do Museu de } \\
\text { Arte" }\end{array}$ & $\begin{array}{c}\text { apresenta a obra de Frans Hals } \\
\text { e as aquisições da pinacoteca } \\
\text { do Museu }\end{array}$ & 3 & 66 & 1951 ABR/JUN & $1951 \mathrm{ABR} / \mathrm{JUN}$ \\
\hline arte & $\begin{array}{l}\text { Wolfgang } \\
\text { Pfeiffer }\end{array}$ & "Coleções brasileiras" & obra de Jacob Jardaens & 3 & 73 & 1951 ABR/JUN & Lina Bo Bardi \\
\hline fotografia & sem autoria & "Fotografias" & $\begin{array}{l}\text { sobre a fotografia abstrata de } \\
\text { Geraldo de Barros e o Foto Cine } \\
\text { Clube Bandeirantes }\end{array}$ & 3 & 75 & 1951 ABR/JUN & Lina Bo Bardi \\
\hline arte & sem autoria & "Uma exposição de Segall” & $\begin{array}{l}\text { divulgação - em setembro no } \\
\text { Museu de Arte de São Paulo }\end{array}$ & 3 & 78 & 1951 ABR/JUN & Lina Bo Bardi \\
\hline arte & Ítalo Faldi & "Paul Klee" & $\begin{array}{c}\text { divulgação da exposição no } \\
\text { MASP e ensaio sobre a obra } \\
\text { de Klee }\end{array}$ & 3 & 79 & 1951 ABR/JUN & Lina Bo Bardi \\
\hline propaganda & Hans Kasser & $\begin{array}{l}\text { "Salão de propaganda" } \\
\text { "L'affiche suisse" }\end{array}$ & $\begin{array}{c}\text { sobre a Exposição do Cartaz } \\
\text { Suíço realizada no MASP. } \\
\text { * (traduzir texto) }\end{array}$ & 3 & 80 & 1951 ABR/JUN & Lina Bo Bardi \\
\hline
\end{tabular}


ÍNDICE CLASSIFICADO E COMENTADO

\begin{tabular}{|c|c|c|c|c|c|c|c|}
\hline TEMA & AUTOR & TÍTULO & DESCRIÇÃO & HABITAT & PÁG. & DATA & DESCRIÇÃO \\
\hline arte & sem autoria & "Marina” & $\begin{array}{l}\text { o talento da jovem artista, com } \\
\text { pequena exposição no Museu. } \\
\text { Pleiteando bolsa de estudos em } \\
\text { Paris - intermédio de } 0 \text {. Andrade }\end{array}$ & 3 & 82 & 1951 ABR/JUN & Lina Bo Bardi \\
\hline arte & Poty & "Viagem de Poty" & $\begin{array}{l}\text { gravura e trecho do diário da } \\
\text { viagem de Poty pela América }\end{array}$ & 3 & 83 & 1951 ABR/JUN & Lina Bo Bardi \\
\hline música & Jorge Wilheim & "Concerto de musica viva" & $\begin{array}{l}\text { sobre a bem sucedida série } \\
\text { de concertos apresentadas no } \\
\text { Museu entre abril e maio }\end{array}$ & 3 & 84 & 1951 ABR/JUN & Lina Bo Bardi \\
\hline cinema & $\begin{array}{l}\text { Florentino } \\
\text { Barbosa e Silva }\end{array}$ & "Problema de vigília" & $\begin{array}{l}\text { sobre a criação do Conselho } \\
\text { Nacional de Cinema, idealizado } \\
\text { pó Getúlio Vargas e organizado } \\
\text { por Cavalcanti. }\end{array}$ & 3 & 85 & 1951 ABR/JUN & Lina Bo Bardi \\
\hline editorial & Lina Bo Bardi & "Primeiro:escolas" & $\begin{array}{l}\text { a importância da educação e } \\
\text { das escolas (arquitetura) na } \\
\text { formação dos indivíduos }\end{array}$ & 4 & 1 & 1951 JUL/SET & Lina Bo Bardi \\
\hline arquitetura & Anísio Teixeira & "Um pressagio do progresso" & $\begin{array}{l}\text { a arquitetura moderna } \\
\text { brasileira como instrumento de } \\
\text { transformação social, ex. as } \\
\text { Escolas do Convênio Escolar }\end{array}$ & 4 & 2 & 1951 JUL/SET & Lina Bo Bardi \\
\hline arquitetura & J. Amadei & "0 que é o Convênio Escolar" & $\begin{array}{l}\text { a origem, as dificuldades, os } \\
\text { objetivos, e as realizações }\end{array}$ & 4 & 3 & 1951 JUL/SET & Lina Bo Bardi \\
\hline arquitetura & Hélio Duarte & $\begin{array}{c}\text { "0 problema escolar e a } \\
\text { arquitetura" }\end{array}$ & $\begin{array}{l}\text { os parâmetros que nortearam } \\
\text { os projetos e as indefinições } \\
\text { do método de ensino a que as } \\
\text { escolas seriam destinadas }\end{array}$ & 4 & 4 & 1951 JUL/SET & Lina Bo Bardi \\
\hline arquitetura & Hélio Duarte & $\begin{array}{c}\text { "As arquiteturas do Convênio } \\
\text { Escolar" }\end{array}$ & $\begin{array}{c}\text { lista dos integrantes da } \\
\text { Comissão do Convênio Escolar } \\
\text { e divulgação de cerca de } 20 \\
\text { projetos }\end{array}$ & 4 & 6 & 1951 JUL/SET & Lina Bo Bardi \\
\hline arte & sem autoria & "Convite a colecionar" & $\begin{array}{l}\text { a importância de colecionar } \\
\text { "valores artísticos" por } \\
\text { particulares }\end{array}$ & 4 & 41 & 1951 JUL/SET & Lina Bo Bardi \\
\hline arte & sem autoria & "Roberto Sambonet" & $\begin{array}{l}\text { crítica a obra do pintor como } \\
\text { uma das maiores contribuições } \\
\text { para a pintura no país. }\end{array}$ & 4 & 43 & 1951 JUL/SET & Lina Bo Bardi \\
\hline arte & sem autoria & "Souza bom pintor" & $\begin{array}{l}\text { crítica a obra do pintor de } \\
\text { Itanhaem como um valoroso } \\
\text { pintor primitivo }\end{array}$ & 4 & 44 & 1951 JUL/SET & Lina Bo Bardi \\
\hline arte & sem autoria & "Gravuras" & $\begin{array}{c}\text { as gravuras como uma arte não } \\
\text { cara e os resultados positivos } \\
\text { do curso de xilogravura do } \\
\text { Museu de Arte }\end{array}$ & 4 & 46 & 1951 JUL/SET & Lina Bo Bardi \\
\hline arte & Jean Cassou & "Pintor de Saudade" & $\begin{array}{c}\text { poesia cuja tema é a obra de } \\
\text { Portinari }\end{array}$ & 4 & 48 & 1951 JUL/SET & Lina Bo Bardi \\
\hline arquitetura & Zoroastro Cunha & "Formas" & $\begin{array}{l}\text { o tempo e a transformação da } \\
\text { arquitetura }\end{array}$ & 4 & 49 & 1951 JUL/SET & Lina Bo Bardi \\
\hline museus & $\begin{array}{l}\text { Pietro Maria } \\
\text { Bardi }\end{array}$ & "Museés hors des limites" & o papel educador dos museus & 4 & 50 & 1951 JUL/SET & Lina Bo Bardi \\
\hline arte & $\begin{array}{l}\text { Pietro Maria } \\
\text { Bardi }\end{array}$ & $\begin{array}{c}\text { "Toulouse-Lautrec no Museu } \\
\text { de Arte" }\end{array}$ & $\begin{array}{l}\text { as nove telas de Lautrec no } \\
\text { acervo do Museu e um breve } \\
\text { histórico }\end{array}$ & 4 & 52 & 1951 JUL/SET & Lina Bo Bardi \\
\hline $\begin{array}{l}\text { desenho } \\
\text { industrial }\end{array}$ & $\begin{array}{l}\text { Pietro Maria } \\
\text { Bardi }\end{array}$ & "Toulouse e o cartaz" & $\begin{array}{l}\text { a necessidade de desenvolver } \\
\text { o campo dos cartazes, ex. } \\
\text { Toulouse }\end{array}$ & 4 & 56 & 1951 JUL/SET & Lina Bo Bardi \\
\hline arte & $\begin{array}{l}\text { Pietro Maria } \\
\text { Bardi }\end{array}$ & "Novas aquisições" & Stuart, Picasso, Constable & 4 & 57 & 1951 JUL/SET & Lina Bo Bardi \\
\hline arte & Frederic Karoly & "Automatismo" & 0 artista e 0 subconsciente & 4 & 59 & $1951 \mathrm{JUL} / \mathrm{SET}$ & Lina Bo Bardi \\
\hline literatura & Tito Batini & $\begin{array}{l}\text { "A senhora Odonais em águas } \\
\text { do Amazonas" }\end{array}$ & $\begin{array}{l}\text { história de naufrágios no } \\
\text { Amazonas }\end{array}$ & 4 & 60 & 1951 JUL/SET & Lina Bo Bardi \\
\hline arquitetura & Tito Batini & “Manaus, teatro & $\begin{array}{l}\text { fotos Roberto Maia retratam a } \\
\text { suntuosidade e hibridismo do } \\
\text { edifício }\end{array}$ & 4 & 62 & 1951 JUL/SET & Lina Bo Bardi \\
\hline arquitetura & Tito Batini & "Manaus, novidades & $\begin{array}{c}\text { o novo Hotel Amazonas - } \\
\text { arquitetura moderna levada a } \\
\text { Manau }\end{array}$ & 4 & 68 & 1951 JUL/SET & Lina Bo Bardi \\
\hline
\end{tabular}


ÍNDICE CLASSIFICADO E COMENTADO

\begin{tabular}{|c|c|c|c|c|c|c|c|}
\hline TEMA & AUTOR & TÍTULO & DESCRIÇÃO & HABITAT & PÁG. & DATA & DESCRIÇÃO \\
\hline arte & Tito Batini & "0 escultor Zamoysky" & $\begin{array}{l}\text { a intenção de inaugurar a } \\
\text { Escola de Escultura (sob a } \\
\text { direção de Zamoysky), Escola } \\
\text { de Cenografia e Escola de } \\
\text { Cerâmica }\end{array}$ & 4 & 69 & 1951 JUL/SET & Lina Bo Bardi \\
\hline arte & Adolf Loos & $\begin{array}{c}\text { "0 retrato, a semelhança e a } \\
\text { arte" }\end{array}$ & $\begin{array}{l}\text { retratar?, na arte deve estar } \\
\text { presente a essência da } \\
\text { pessoa.(obra de Zamoysky - } \\
\text { retrato de Adolf Loos) }\end{array}$ & 4 & 70 & 1951 JUL/SET & Lina Bo Bardi \\
\hline arte & sem autoria & "A Escola de Escultura" & $\begin{array}{l}\text { entrevista com Zamoysky sobre } \\
\text { o programa de ensino da Escola } \\
\text { de Escultura }\end{array}$ & 4 & 76 & 1951 JUL/SET & Lina Bo Bardi \\
\hline arquitetura & sem autoria & "Arquitetura e religião" & $\begin{array}{c}\text { a má arquitetura, inadequada } \\
\text { a época - ex. Catedral de São } \\
\text { Paulo }\end{array}$ & 4 & 77 & 1951 JUL/SET & Lina Bo Bardi \\
\hline arquitetura & Alencastro & "Carta aberta" & $\begin{array}{l}\text { à Ciccilo. coordenador do } \\
\text { IV Centenário. Sugestões à } \\
\text { Exposição de Arquitetura }\end{array}$ & 4 & 78 & 1951 JUL/SET & Lina Bo Bardi \\
\hline arquitetura & Alencastro & "Album de fotografias" & $\begin{array}{c}\text { a arquitetura anônima de São } \\
\text { Paulo (fotos P.M. Bardi e Alice } \\
\text { Brill) }\end{array}$ & 4 & 80 & 1951 JUL/SET & Lina Bo Bardi \\
\hline bailado & Laura Moret & "Cortizona para Terpsicore" & $\begin{array}{c}\text { a falta de investimento } \\
\text { no bailado no Brasil e a } \\
\text { necessidade de se criar o Teatro } \\
\text { Brasileiro de Ballet }\end{array}$ & 4 & 83 & 1951 JUL/SET & Lina Bo Bardi \\
\hline cinema & Francesco Biagi & "Necessitam-se artesãos" & $\begin{array}{c}\text { os lentos avanços do cinema } \\
\text { brasileiro e a especulação em } \\
\text { torno do C.N.C coordenado por } \\
\text { Cavalcanti }\end{array}$ & 4 & 84 & 1951 JUL/SET & Lina Bo Bardi \\
\hline música & L'E & Angelicum & $\begin{array}{c}\text { a música clássica italiana no } \\
\text { Brasil }\end{array}$ & 4 & 85 & 1951 JUL/SET & Lina Bo Bardi \\
\hline editorial & Lina Bo Bardi & "Bienal” & $\begin{array}{l}\text { sobre a oficialização das Bienais } \\
\text { de arte e o risco de adquirir } \\
\text { vícios de organismo público }\end{array}$ & 5 & 1 & 1951 OUT/DEZ & Lina Bo Bardi \\
\hline arte & Serafim & “0 repórter da Bienal” & $\begin{array}{c}\text { crítica a exposição (imagens das } \\
\text { obras expostas) }\end{array}$ & 5 & 2 & 1951 OUT/DEZ & Lina Bo Bardi \\
\hline arte & $\begin{array}{l}\text { Pietro Maria } \\
\text { Bardi }\end{array}$ & "Lasar Segall na Alemanha" & $\begin{array}{c}\text { meio artístico e aspectos que } \\
\text { influenciaram a formação } \\
\text { artística de Segall }\end{array}$ & 5 & 22 & 1951 OUT/DEZ & Lina Bo Bardi \\
\hline arte & $\begin{array}{l}\text { Pietro Maria } \\
\text { Bardi }\end{array}$ & "Contribuições ao Barroco" & $\begin{array}{l}\text { a importância do "barroco } \\
\text { colonial", arte espontânea }\end{array}$ & 5 & 32 & 1951 OUT/DEZ & Lina Bo Bardi \\
\hline cinema & $\begin{array}{l}\text { Marcus } \\
\text { Margulies }\end{array}$ & "Os tiranos de Antoine Caron" & $\begin{array}{l}\text { filmagem de um quadro do } \\
\text { Museu realizada no curso de } \\
\text { cinema do Museu }\end{array}$ & 5 & 33 & 1951 OUT/DEZ & Lina Bo Bardi \\
\hline arte & sem autoria & "Alguns Gatos" & a presença dos gatos nas artes & 5 & 37 & 1951 OUT/DEZ & Lina Bo Bardi \\
\hline arte & $\begin{array}{l}\text { Wolfgang } \\
\text { Pfeiffer }\end{array}$ & "Uma mina do barroco" & $\begin{array}{l}\text { a "mina" descoberta no museu } \\
\text { da Cúria Metropolitana do } \\
\text { Arcebispado Paulistano }\end{array}$ & 5 & 40 & 1951 OUT/DEZ & Lina Bo Bardi \\
\hline arte & $\begin{array}{l}\text { Alceu Maynard } \\
\text { Araujo }\end{array}$ & "Ex-votos e 'premessas'” & $\begin{array}{l}\text { pesquisa sobre "ex-votos", suas } \\
\text { origens, categorias e relevância }\end{array}$ & 5 & 42 & 1951 OUT/DEZ & Lina Bo Bardi \\
\hline arquitetura & Eduardo Corona & $\begin{array}{l}\text { "Da necessidade de crítica sobre } \\
\text { arquitetura" }\end{array}$ & $\begin{array}{l}\text { a importância e ausência da } \\
\text { crítica de arquitetura no Brasil }\end{array}$ & 5 & 46 & 1951 OUT/DEZ & Lina Bo Bardi \\
\hline arquitetura & $\begin{array}{l}\text { Giusta Nicco } \\
\text { Fasola }\end{array}$ & "A arte menos estudada" & $\begin{array}{l}0 \text { desconhecimento em relação } \\
\text { a arquitetura }\end{array}$ & 5 & 47 & 1951 OUT/DEZ & Lina Bo Bardi \\
\hline arquitetura & sem autoria & "Uma residência em São Paulo" & $\begin{array}{c}\text { descritivo - arq. Gilberto Tinoco } \\
\text { e Ibsen Pivatelli (projeto + } \\
\text { perspectivas) }\end{array}$ & 5 & 48 & 1951 OUT/DEZ & Lina Bo Bardi \\
\hline arquitetura & sem autoria & "Residência em São Paulo" & $\begin{array}{l}\text { descritivo duas residências } \\
\text { - arq. Eduardo Corona e Roberto } \\
\text { Tibau (projeto + perspectivas) }\end{array}$ & 5 & 50 & 1951 OUT/DEZ & Lina Bo Bardi \\
\hline artesanato & sem autoria & "Arte Popular" & artesanato de Pernambuco & 5 & 55 & 1951 OUT/DEZ & Lina Bo Bardi \\
\hline
\end{tabular}


ÍNDICE CLASSIFICADO E COMENTADO

\begin{tabular}{|c|c|c|c|c|c|c|c|}
\hline TEMA & AUTOR & TÍTULO & DESCRIÇÃO & HABITAT & PÁG. & DATA & DESCRIÇÃO \\
\hline $\begin{array}{l}\text { desenho } \\
\text { industrial }\end{array}$ & sem autoria & Leopold Haar & $\begin{array}{c}\text { a imigrado da Polônia para a } \\
\text { Itália e depois para o Brasil, } \\
\text { importante artista p/ a Olivetti e } \\
\text { leciona no IAC }\end{array}$ & 5 & 56 & 1951 OUT/DEZ & Lina Bo Bardi \\
\hline $\begin{array}{l}\text { desenho } \\
\text { industrial }\end{array}$ & Leopold Haar & "Plásticas novas" & $\begin{array}{l}\text { a importância do projeto } \\
\text { de vitrinas - uma questão } \\
\text { de arquitetura - estudo de } \\
\text { composições de Leopoldo Haar }\end{array}$ & 5 & 57 & 1951 OUT/DEZ & Lina Bo Bardi \\
\hline $\begin{array}{l}\text { desenho } \\
\text { industrial }\end{array}$ & Lina Bo Bardi & "Vitrinas" & $\begin{array}{l}\text { o compromisso público das } \\
\text { vitrinas - a "sala de estar" da } \\
\text { cidade }\end{array}$ & 5 & 60 & 1951 OUT/DEZ & Lina Bo Bardi \\
\hline $\begin{array}{l}\text { desenho } \\
\text { industrial }\end{array}$ & Lina Bo Bardi & "Desenho Industrial” & $\begin{array}{l}\text { o desenho industrial baseado } \\
\text { nas leis da natureza, nas normas } \\
\text { estéticas e da função que a } \\
\text { época define }\end{array}$ & 5 & 62 & 1951 OUT/DEZ & Lina Bo Bardi \\
\hline $\begin{array}{c}\text { desenho } \\
\text { industrial }\end{array}$ & Lina Bo Bardi & "Dois objetos" & $\begin{array}{l}\text { A "verdade"presente nas formas } \\
\text { puras de objetos populares }\end{array}$ & 5 & 64 & 1951 OUT/DEZ & Lina Bo Bardi \\
\hline $\begin{array}{l}\text { desenho } \\
\text { industrial }\end{array}$ & sem autoria & "Tecidos de Lili" & $\begin{array}{l}\text { a técnica das estampas nos } \\
\text { tecidos de Lilli Corrêa de Araújo }\end{array}$ & 5 & 65 & 1951 OUT/DEZ & Lina Bo Bardi \\
\hline arquitetura & sem autoria & "Morumbi" & $\begin{array}{c}0 \text { risco do novo bairro } \\
\text { transformar-se em um novo } \\
\text { Jardim América ou Europa - a } \\
\text { necessidade de boa arquitetura }\end{array}$ & 5 & 66 & 1951 OUT/DEZ & Lina Bo Bardi \\
\hline arquitetura & sem autoria & "Numa igreja" & $\begin{array}{l}\text { afrescos de Lucia Suané na } \\
\text { igreja velha do Morumbi, recém } \\
\text { restaurada por WarchavichiK }\end{array}$ & 5 & 67 & 1951 OUT/DEZ & Lina Bo Bardi \\
\hline fotografia & sem autoria & "Fotografia" & $\begin{array}{l}\text { X Salão Internacional de Arte } \\
\text { Fotográfica - Foto- Cine Clube } \\
\text { Bandeirante }\end{array}$ & 5 & 68 & 1951 OUT/DEZ & Lina Bo Bardi \\
\hline arte & sem autoria & "Pinturas nas ruas" & $\begin{array}{l}\text { o figurativismo que atrai } 0 \\
\text { homem comum nas pintura das } \\
\text { ruas, distante da arte moderna }\end{array}$ & 5 & 70 & 1951 OUT/DEZ & Lina Bo Bardi \\
\hline arte & sem autoria & $\begin{array}{l}\text { "A Pinacoteca do Museu de } \\
\text { Arte" }\end{array}$ & $\begin{array}{l}\text { novas aquisições - Gauguin, } \\
\text { Boucher, Degas, Zurbaran }\end{array}$ & 5 & 71 & 1951 OUT/DEZ & Lina Bo Bardi \\
\hline arte & sem autoria & "Mojólicas no Museu” & $\begin{array}{c}\text { aquisição pelo museu de } \\
\text { cerâmicas mojólicas italianas do } \\
\text { séc. XIII até o XVI }\end{array}$ & 5 & 75 & 1951 OUT/DEZ & Lina Bo Bardi \\
\hline arte & sem autoria & "Coleções particulares" & $\begin{array}{c}\text { sobre o importante exemplar } \\
\text { de Guercino em na coleção } \\
\text { particular do Dr. Moacir Vieira } \\
\text { Martins }\end{array}$ & 5 & 78 & 1951 OUT/DEZ & Lina Bo Bardi \\
\hline arte & $\begin{array}{l}\text { Pietro Maria } \\
\text { Bardi }\end{array}$ & "Exposição de reproduções" & $\begin{array}{l}\text { a importância das obras gráficas } \\
\text { - gravuras e coleções gráficas } \\
\text { - principalmente para a difusão } \\
\text { da arte os fac-símiles }\end{array}$ & 5 & 79 & 1951 OUT/DEZ & Lina Bo Bardi \\
\hline arte & $\begin{array}{l}\text { Pietro Maria } \\
\text { Bardi }\end{array}$ & "Alberto Latuada “ & $\begin{array}{l}\text { a importância da formação de } \\
\text { arquitetura para o cineasta }\end{array}$ & 5 & 80 & 1951 OUT/DEZ & Lina Bo Bardi \\
\hline cinema & Arturo Usai & $\begin{array}{l}\text { "Argumento para um filme sobre } \\
\text { uma cidade morta" }\end{array}$ & $\begin{array}{l}\text { a dificuldade econômica para } \\
\text { a realização do filme sobre } \\
\text { Parati (imagens-documentário } \\
\text { fotográfico de Parati) }\end{array}$ & 5 & 81 & 1951 OUT/DEZ & Lina Bo Bardi \\
\hline bailado & Vaslav Veltechek & "Notas para uma história" & $\begin{array}{l}\text { ensaio sobre a história da } \\
\text { dança no Brasil }\end{array}$ & 5 & 86 & 1951 OUT/DEZ & Lina Bo Bardi \\
\hline teatro & M. D. S. & "Jaime Costa" & $\begin{array}{l}\text { elogio a montagem "A morte do } \\
\text { caixeiro viajante" e incentivo ao } \\
\text { ator para não se enveredar pela } \\
\text { chanchada }\end{array}$ & 5 & 88 & 1952 JAN/MAR & Lina Bo Bardi \\
\hline editorial & Lina Bo Bardi & " 0 centenário" & $\begin{array}{c}\text { sobre os preparativos da } \\
\text { comemoração do IV Centenário } \\
\text { - crítica a Francisco Matarazzo, } \\
\text { sugestões a construção de uma } \\
\text { Universidade, }\end{array}$ & 6 & 1 & 1952 JAN/MAR & Lina Bo Bardi \\
\hline arte & Lina Bo Bardi & "Um artigo do semanal Arts" & $\begin{array}{c}\text { a revista Habitat como tributária } \\
\text { ao Museu de Arte, iniciativa de } \\
\text { Assis Chateaubriand }\end{array}$ & 6 & 2 & 1952 JAN/MAR & Lina Bo Bardi \\
\hline
\end{tabular}


ÍNDICE CLASSIFICADO E COMENTADO

\begin{tabular}{|c|c|c|c|c|c|c|c|}
\hline TEMA & AUTOR & TÍTULO & DESCRIÇÃO & HABITAT & PÁG. & DATA & DESCRIÇÃO \\
\hline arte & $\begin{array}{l}\text { Assis } \\
\text { Chateaubriand }\end{array}$ & $\begin{array}{c}\text { "Obras de arte recebidas como } \\
\text { personagens" }\end{array}$ & $\begin{array}{l}\text { discurso de Chateaubriand para } \\
\text { receber novos quadros para } 0 \\
\text { acervo do Museu }\end{array}$ & 6 & 3 & 1952 JAN/MAR & Lina Bo Bardi \\
\hline arte & $\begin{array}{c}\text { Assis } \\
\text { Chateaubriand }\end{array}$ & "A Pinacoteca do Museu" & $\begin{array}{c}\text { Camile Carot, Henri Matisse e } \\
\text { Paul Cézanne ( e seus doadores) }\end{array}$ & 6 & 4 & 1952 JAN/MAR & Lina Bo Bardi \\
\hline arte & $\begin{array}{c}\text { Assis } \\
\text { Chateaubriand }\end{array}$ & "Ticiano" & $\begin{array}{c}\text { sobre a obra do pintor, parte do } \\
\text { acervo do Museu }\end{array}$ & 6 & 6 & 1952 JAN/MAR & Lina Bo Bardi \\
\hline arte & $\begin{array}{c}\text { Assis } \\
\text { Chateaubriand }\end{array}$ & "Cézanne" & $\begin{array}{c}\text { cinco exemplares no Museu, } \\
\text { três deles emprestados para } \\
\text { grandes exposições de Chicago } \\
\text { e NY }\end{array}$ & 6 & 8 & 1952 JAN/MAR & Lina Bo Bardi \\
\hline arte & $\begin{array}{l}\text { Assis } \\
\text { Chateaubriand }\end{array}$ & $\begin{array}{l}\text { "O retrato francês no Museu } \\
\text { de Arte" }\end{array}$ & $\begin{array}{c}\text { sobre as atividades do Museu, } \\
\text { a exposições sobre o Retrato } \\
\text { Francês a ser organizada }\end{array}$ & 6 & 9 & 1952 JAN/MAR & Lina Bo Bardi \\
\hline arte & $\begin{array}{c}\text { Assis } \\
\text { Chateaubriand }\end{array}$ & "Steinberg no Brasil" & $\begin{array}{l}\text { sobre a exposição que se } \\
\text { realizará no Museu }\end{array}$ & 6 & 15 & 1952 JAN/MAR & Lina Bo Bardi \\
\hline arte & Serafim & "Retrato de Yan" & $\begin{array}{c}\text { Yan (João Fernando de } \\
\text { Almeida Prado) e o progresso } \\
\text { em São Paulo. A recusa da } \\
\text { municipalidade da doação de } \\
\text { sua biblioteca particular }\end{array}$ & 6 & 16 & 1952 JAN/MAR & Lina Bo Bardi \\
\hline arte & $\begin{array}{l}\text { Tarsila do } \\
\text { Amaral }\end{array}$ & "Recordações de Paris" & $\begin{array}{c}\text { As diferentes Paris - antes e } \\
\text { depois de } 1922 \text { para Tarsila., } \\
\text { presentes em sua formação } \\
\text { artística }\end{array}$ & 6 & 17 & 1952 JAN/MAR & Lina Bo Bardi \\
\hline literatura & Blaise Cendrars & "Saint-Paul" & poesia para Tarsila & 6 & 26 & 1952 JAN/MAR & Lina Bo Bardi \\
\hline arte & sem autoria & "Fundar" & $\begin{array}{c}\text { sobre o IV Centenário de São } \\
\text { Paulo }\end{array}$ & 6 & 27 & 1952 JAN/MAR & Lina Bo Bardi \\
\hline arte & José Valladares & "A pintura popular na Bahia" & suas características e riquezas & 6 & 28 & 1952 JAN/MAR & Lina Bo Bardi \\
\hline arte & Roger Bastide & $\begin{array}{l}\text { "Art et religion: Le culte des } \\
\text { Jumeaux" }\end{array}$ & traduzir & 6 & 32 & 1952 JAN/MAR & Lina Bo Bardi \\
\hline artesanato & Lina Bo Bardi & "Ourivesaria” & $\begin{array}{l}\text { a necessidade de incorporar } \\
\text { características brasileiras } \\
\text { (imagens de peças) }\end{array}$ & 6 & 34 & 1952 JAN/MAR & Lina Bo Bardi \\
\hline $\begin{array}{l}\text { desenho } \\
\text { industrial }\end{array}$ & sem autoria & "Grupo de móveis" & exemplos de pequenas peças & 6 & 36 & 1952 JAN/MAR & Lina Bo Bardi \\
\hline fotografia & Marc Berkowitz & "Sascha Harnisch, fotografo" & $\begin{array}{c}\text { o reconhecimento da fotografia } \\
\text { como arte (o trabalho de Sascha } \\
\text { Harnisch) }\end{array}$ & 6 & 37 & 1952 JAN/MAR & Lina Bo Bardi \\
\hline arte & $\begin{array}{l}\text { Pietro Maria } \\
\text { Bardi }\end{array}$ & "Pintores" & $\begin{array}{l}\text { a importância das pinturas que } \\
\text { retratam a história do Brasil } \\
\text { (segue imagens de Frans Post e } \\
\text { Gillis Peeters) }\end{array}$ & 6 & 42 & 1952 JAN/MAR & Lina Bo Bardi \\
\hline arte & sem autoria & "Juventude" & $\begin{array}{l}\text { Sugestão de a imprensa } \\
\text { apresentar programas } \\
\text { educativos em suas } \\
\text { programações }\end{array}$ & 6 & 46 & 1952 JAN/MAR & Lina Bo Bardi \\
\hline museus & $\begin{array}{l}\text { Pietro Maria } \\
\text { Bardi }\end{array}$ & "A cultura figurativa na infância" & $\begin{array}{l}\text { a educação infantil pela arte - } 0 \\
\text { papel dos Museus }\end{array}$ & 6 & 47 & 1952 JAN/MAR & Lina Bo Bardi \\
\hline museus & Mario da Silva & "0 carro em frente aos bois" & $\begin{array}{c}\text { crítica da arte moderna } \\
\text { anteceder a aquisição da } \\
\text { histórica no Brasil }\end{array}$ & 6 & 50 & 1952 JAN/MAR & Lina Bo Bardi \\
\hline arquitetura & sem autoria & "Corpus do Barroco" & $\begin{array}{c}\text { a necessidade da documentação } \\
\text { e conservação da arquitetura e } \\
\text { da arte do Barroco brasileiro }\end{array}$ & & 52 & 1952 JAN/MAR & Lina Bo Bardi \\
\hline arquitetura & sem autoria & "Uma casa no Rio de Janeiro" & $\begin{array}{c}\text { crítica em torno da constituição } \\
\text { da arq. Moderna brasileira, obra } \\
\text { de Redig (peças gráficas + } \\
\text { imagens) }\end{array}$ & 6 & 57 & 1952 JAN/MAR & Lina Bo Bardi \\
\hline arquitetura & sem autoria & "Um cinema em São Paulo" & $\begin{array}{l}\text { projeto de Alfredo Mathias } \\
\text { e GianCarlo Palanti } \\
\text { (texto descitivo + peças } \\
\text { gráficas + imagens) }\end{array}$ & 6 & 64 & 1952 JAN/MAR & Lina Bo Bardi \\
\hline
\end{tabular}


ÍNDICE CLASSIFICADO E COMENTADO

\begin{tabular}{|c|c|c|c|c|c|c|c|}
\hline TEMA & AUTOR & TÍTULO & DESCRIÇÃO & HABITAT & PÁG. & DATA & DESCRIÇÃO \\
\hline arquitetura & sem autoria & "Edifício em Santos" & $\begin{array}{l}\text { projeto de Hélio Duarte } \\
\text { e E. Carvalho Mange } \\
\text { (texto descritivo + peças } \\
\text { gráficas+imagens) }\end{array}$ & 6 & 66 & 1952 JAN/MAR & Lina Bo Bardi \\
\hline arquitetura & sem autoria & "Um jardim" & $\begin{array}{l}\text { projeto paisagístico para uma } \\
\text { residência de Roberto Coelho } \\
\text { Cardozo e Susan Osborn Coelho } \\
\text { (descritivo+peças gráficas) }\end{array}$ & 6 & 69 & 1952 JAN/MAR & Lina Bo Bardi \\
\hline arquitetura & sem autoria & "Arquitetura e ajardinagen" & $\begin{array}{l}\text { exemplos de elementos } \\
\text { paisagísticos e suas utilizações } \\
\text { (imagens do Arq. Coelho } \\
\text { Cardoso) }\end{array}$ & 6 & 70 & 1952 JAN/MAR & Lina Bo Bardi \\
\hline arquitetura & Flávio Motta & "Verde em São Paulo" & $\begin{array}{c}\text { A necessidade da } \\
\text { implementação de vegetação em } \\
\text { São Paulo e divulgaçã̃o de curso } \\
\text { de "ajardinagem" no Museu }\end{array}$ & 6 & 72 & 1952 JAN/MAR & Lina Bo Bardi \\
\hline arquitetura & sem autoria & "Cartazes" & $\begin{array}{l}\text { sobre a lei que pune a fixação } \\
\text { indiscriminada de cartazes em } \\
\text { espaços públicos }\end{array}$ & 6 & 74 & 1952 JAN/MAR & Lina Bo Bardi \\
\hline arte & sem autoria & "Um livro sobre de Fiori" & $\begin{array}{l}\text { sobre a publicação, pelo Museu } \\
\text { de Arte, do livro sobre a obra } \\
\text { do artista }\end{array}$ & 6 & 75 & 1952 JAN/MAR & \\
\hline arte & sem autoria & "Ver e compreender" & $\begin{array}{l}\text { sobre a rejeição do público a } \\
\text { exposição "Convite do estudo da } \\
\text { Geometria" }\end{array}$ & 6 & 76 & 1952 JAN/MAR & \\
\hline arte & sem autoria & "Arte religiosa" & $\begin{array}{l}\text { sobre a mostra de arte religiosa } \\
\text { no Museu, representada por } \\
\text { artistas de todas as tendências }\end{array}$ & 6 & 77 & 1952 JAN/MAR & Lina Bo Bardi \\
\hline arte & Serafim & “0 índio na Bienal” & $\begin{array}{c}\text { crítica a algumas obras enviadas } \\
\text { a Bienal de Arte }\end{array}$ & 6 & 78 & 1952 JAN/MAR & \\
\hline arte & sem autoria & "Um xilógrafo" & $\begin{array}{l}\text { sobre } 0 \text { artista Berco Udler, } \\
\text { residente no Brasil }\end{array}$ & 6 & 80 & 1952 JAN/MAR & \\
\hline cinema & $\begin{array}{l}\text { Alberto } \\
\text { Cavalcanti }\end{array}$ & "A nova etapa" & $\begin{array}{l}\text { reflexões de Alberto Cavalcanti, } \\
\text { retiradas do manuscrito de um } \\
\text { livro a ser publicado }\end{array}$ & 6 & 81 & 1952 JAN/MAR & Lina Bo Bardi \\
\hline música & Edino Krieger & $\begin{array}{c}\text { "A Orquestra sinfônica juvenil do } \\
\text { Museu de Arte" }\end{array}$ & $\begin{array}{c}\text { sobre o apoio geral e } \\
\text { principalmente do Museu dado } \\
\text { à Orquestra }\end{array}$ & 6 & 82 & 1952 JAN/MAR & \\
\hline música & Edino Krieger & $\begin{array}{l}\text { "Koellreutler e nosso meio } \\
\text { musical" }\end{array}$ & $\begin{array}{c}\text { a transferência do musicista } \\
\text { para o Brasil e a importância } \\
\text { dessa para sua carreira }\end{array}$ & 6 & 84 & 1952 JAN/MAR & Lina Bo Bardi \\
\hline teatro & $\begin{array}{l}\text { Wolfgang } \\
\text { Pfeiffer }\end{array}$ & "Cenografia” & $\begin{array}{l}\text { seu desenvolvimento em São } \\
\text { Paulo }\end{array}$ & 6 & 85 & 1952 JAN/MAR & Lina Bo Bardi \\
\hline cinema & M. D. S. & "Maria della Costa" & seu talento e beleza & 6 & 86 & 1952 JAN/MAR & Lina Bo Bardi \\
\hline editorial & Emilio Villa & $\begin{array}{l}\text { "Os puristas são enfadonhos e } \\
\text { inúteis" }\end{array}$ & $\begin{array}{c}\text { resposta à crítica dirigida a } \\
\text { Habitat (má utilização da língua } \\
\text { portuguesa) e a inexistência de } \\
\text { uma língua pura }\end{array}$ & 7 & 1 & 1952 ABR/JUN & Lina Bo Bardi \\
\hline arquitetura & $\begin{array}{l}\text { atribuido a Lina } \\
\text { Bo Bardi }\end{array}$ & "Construir é viver" & $\begin{array}{l}\text { sobre a sabedoria do arquiteto } \\
\text { do povo (imagens de uma } \\
\text { construção na Amazônia) }\end{array}$ & 7 & 3 & 1952 ABR/JUN & \\
\hline arquitetura & sem autoria & "Casa de um arquiteto" & $\begin{array}{c}\text { projeto de H. Verona Christojani } \\
\text { descritivo -(peças gráficas e } \\
\text { imagem) }\end{array}$ & 7 & 10 & 1952 ABR/JUN & \\
\hline arquitetura & $\begin{array}{l}\text { Oswaldo Correia } \\
\text { Gonçalves }\end{array}$ & $\begin{array}{l}\text { "Arquitetura de Sérgio } \\
\text { Bernardes" }\end{array}$ & $\begin{array}{l}\text { análise crítica à obra do } \\
\text { arquiteto e } 2 \text { projetos } \\
\text { residenciais (peças } \\
\text { gráficas + imagens) }\end{array}$ & 7 & 11 & 1952 ABR/JUN & Lina Bo Bardi \\
\hline arquitetura & $\begin{array}{l}\text { Abelardo de } \\
\text { Souza }\end{array}$ & $\begin{array}{l}\text { "Prédio de apartamentos em } \\
\text { São Paulo" }\end{array}$ & descritivo + peças gráficas & 7 & 18 & 1952 ABR/JUN & \\
\hline $\begin{array}{l}\text { desenho } \\
\text { industrial }\end{array}$ & $\begin{array}{l}\text { L. A. Falcão } \\
\text { Bauer }\end{array}$ & "Mobiliário Escolar" & as necessidades do redesenhar & 7 & 21 & 1952 ABR/JUN & Lina Bo Bardi \\
\hline arquitetura & sem autoria & "Convênio Escolar" & $\begin{array}{l}2 \text { projetos - descritivo + peças } \\
\text { gráficas + imagens }\end{array}$ & 7 & 22 & 1952 ABR/JUN & \\
\hline arte & sem autoria & $\begin{array}{l}\text { "Qual o futuro das artes no } \\
\text { Brasil?" }\end{array}$ & declarações de alguns artistas & 7 & 26 & 1952 ABR/JUN & Lina Bo Bardi \\
\hline
\end{tabular}


ÍNDICE CLASSIFICADO E COMENTADO

\begin{tabular}{|c|c|c|c|c|c|c|c|}
\hline TEMA & AUTOR & TÍTULO & DESCRIÇÃO & HABITAT & PÁG. & DATA & DESCRIÇÃO \\
\hline literatura & R. Bairão & $\begin{array}{l}\text { "Poetas novos escolhidos por } \\
\text { Reynaldo Bairão" }\end{array}$ & $\begin{array}{c}\text { entre outros: João Cabral de } \\
\text { Melo Neto, Paulo Sérgio Milliet, } \\
\text { Augusto de Campos, Haroldo de } \\
\text { Campos,etc }\end{array}$ & 7 & 34 & 1952 ABR/JUN & \\
\hline arte & Lina Bo Bardi & "Enrico Bo" & $\begin{array}{l}\text { a divulgação da obra do artista } \\
\text { que começou a pintar tarde e a } \\
\text { impecável técnica que o levará } \\
\text { à exposições em New York e } \\
\text { São Paulo }\end{array}$ & 7 & 36 & 1952 ABR/JUN & Lina Bo Bardi \\
\hline arte & sem autoria & "Liese" & $\begin{array}{l}\text { promessa do jovem artista Liese } \\
\text { Modern, aluno do curso de } \\
\text { gravura do Museu }\end{array}$ & 7 & 38 & 1952 ABR/JUN & \\
\hline arte & sem autoria & "Mais um primitivo" & sobre Agostinho Batista Freitas & 7 & 40 & 1952 ABR/JUN & \\
\hline arte & sem autoria & "Mais uma amadora" & a ingenuidade na arte amadora & 7 & 40 & 1952 ABR/JUN & \\
\hline arte & sem autoria & "Renina" & $\begin{array}{l}\text { sobre o trabalho de gravura da } \\
\text { artista, exposto no Museu }\end{array}$ & 7 & 42 & 1952 ABR/JUN & \\
\hline arte & sem autoria & "Um brado de alarma" & $\begin{array}{l}\text { o descaso da cúria com a } \\
\text { arte religiosa. Denuncia da } \\
\text { destruição dos afrescos de } \\
\text { Macier na capela de Mauá }\end{array}$ & 7 & 43 & 1952 ABR/JUN & Lina Bo Bardi \\
\hline fotografia & sem autoria & "Antigas paisagens" & $\begin{array}{c}\text { imagem antiga enviada por } \\
\text { leitora }\end{array}$ & 7 & 48 & 1952 ABR/JUN & \\
\hline arquitetura & sem autoria & "Novas paisagens" & $\begin{array}{c}\text { imagem da barragem do Rio } \\
\text { Paraíba -arquitetura como } \\
\text { transformação da natureza pelo } \\
\text { homem }\end{array}$ & 7 & 49 & 1952 ABR/JUN & Lina Bo Bardi \\
\hline arquitetura & sem autoria & "Um escritório” & $\begin{array}{l}\text { Sede da Editora Domus } \\
\text { - Studio de Arte Palma - } \\
\text { descritivo+imagens }\end{array}$ & 7 & 50 & 1952 ABR/JUN & \\
\hline arquitetura & sem autoria & $\begin{array}{l}\text { "Necessidade da crítica de } \\
\text { arquitetura" }\end{array}$ & $\begin{array}{l}\text { as questões que a envolvem, e } \\
\text { por isso a dificuldade em fazê-la }\end{array}$ & 7 & 53 & 1952 ABR/JUN & Lina Bo Bardi \\
\hline fotografia & $\begin{array}{l}\text { Lina Bo Bardi } \\
(?)\end{array}$ & "Fotografias" & imagens diversas & 7 & 54 & 1952 ABR/JUN & \\
\hline arte & Flávio Motta & “Diana atormentada' & $\begin{array}{c}\text { descreve a obra atribuída a } \\
\text { Bernini }\end{array}$ & 7 & 55 & 1952 ABR/JUN & Lina Bo Bardi \\
\hline arte & $\begin{array}{l}\text { J. F. de Almeida } \\
\text { Prado }\end{array}$ & $\begin{array}{l}\text { "Paulo Prado, patrocinador da } \\
\text { Semana de Arte moderna" }\end{array}$ & $\begin{array}{l}\text { o envolvimento de Paulo Prado } \\
\text { com a semana }\end{array}$ & 7 & 58 & 1952 ABR/JUN & Lina Bo Bardi \\
\hline arte & sem autoria & "Pedro Américo" & $\begin{array}{l}\text { sobre a pintura de Pedro } \\
\text { Américo }\end{array}$ & 7 & 60 & 1952 ABR/JUN & Lina Bo Bardi \\
\hline artesanato & $\begin{array}{l}\text { C. Cortese } \\
\text { Caldas }\end{array}$ & "Cerâmica dos Carajás" & $\begin{array}{l}\text { a importância da arte indígena, } \\
\text { reconhecida pelo Museu }\end{array}$ & 7 & 61 & 1952 ABR/JUN & Lina Bo Bardi \\
\hline arte & sem autoria & "Para um museu do café" & $\begin{array}{l}\text { proposta de criação de museu } \\
\text { em torno do tema }\end{array}$ & 7 & 71 & 1952 ABR/JUN & Lina Bo Bardi \\
\hline arte & sem autoria & $\begin{array}{l}\text { "Dois convites ao Museu de } \\
\text { Arte" }\end{array}$ & $\begin{array}{l}\text { a importância do acervo } \\
\text { do Museu, convidado para } \\
\text { expor em grandes exposições } \\
\text { internacionais }\end{array}$ & 7 & 72 & 1952 ABR/JUN & Lina Bo Bardi \\
\hline moda & sem autoria & "A moda no Brasil" & $\begin{array}{c}\text { a necessidade de } \\
\text { desenvolvimento da moda com } \\
\text { características nacionais - } 0 \\
\text { papel do Museu }\end{array}$ & 7 & 76 & 1952 ABR/JUN & Lina Bo Bardi \\
\hline museus & sem autoria & "Crianças" & a educação pela arte & 7 & 77 & 1952 ABR/JUN & \\
\hline propaganda & $\begin{array}{l}\text { Rodolfo Lima } \\
\text { Martensen }\end{array}$ & "Arte e Propaganda" & $\begin{array}{l}\text { sobre as atividades da Escola de } \\
\text { Propaganda do Museu de Arte }\end{array}$ & 7 & 78 & 1952 ABR/JUN & Lina Bo Bardi \\
\hline arquitetura & Jorge Wilheim & "Jovem brasileiro na Europa" & $\begin{array}{l}\text { notas de viagem a Europa - } \\
\text { sobre a crítica internacional em } \\
\text { relação a arquitetura brasileira }\end{array}$ & 7 & 81 & 1952 ABR/JUN & Lina Bo Bardi \\
\hline música & Lydia Alimonda & "Repercussão na Europa” & $\begin{array}{c}\text { a imagem do Brasil reflete na } \\
\text { crítica a Música brasileira no } \\
\text { exterior }\end{array}$ & 7 & 82 & 1952 ABR/JUN & Lina Bo Bardi \\
\hline bailado & sem autoria & "Conjunto de dança expressiva" & $\begin{array}{c}\text { curso no Museu ministrado por } \\
\text { Yanka Rudzka }\end{array}$ & 7 & 83 & 1952 ABR/JUN & Lina Bo Bardi \\
\hline
\end{tabular}


ÍNDICE CLASSIFICADO E COMENTADO

\begin{tabular}{|c|c|c|c|c|c|c|c|}
\hline TEMA & AUTOR & TÍTULO & DESCRIÇÃO & HABITAT & PÁG. & DATA & DESCRIÇÃO \\
\hline editorial & sem autoria & "Arranha-céus e o espírito" & $\begin{array}{c}\text { 0 compromisso de Habitat com } \\
\text { o que a discussão em torno do } \\
\text { Brasil e com o desenvolvimento } \\
\text { cultural brasileiro }\end{array}$ & 8 & 1 & 1952JUL/SET & Lina Bo Bardi \\
\hline museus & sem autoria & $\begin{array}{c}\text { "Balanços e perspectivas } \\
\text { museográficas: O Museu de São } \\
\text { Vicente" }\end{array}$ & $\begin{array}{l}\text { A Missão Educadora do MASP, } \\
\text { o balanço de suas atividades e } \\
\text { o Museu de São Vicente como } \\
\text { desafio }\end{array}$ & 8 & 2 & 1952JUL/SET & Lina Bo Bardi \\
\hline arquitetura & Lina Bo Bardi & "Museu a beira do oceano" & $\begin{array}{l}\text { descritivo do Museu de São } \\
\text { Vicente + peças gráfica }\end{array}$ & 8 & 6 & 1952JUL/SET & Lina Bo Bardi \\
\hline museus & sem autoria & $\begin{array}{l}\text { "Os museus vivos nos Estados } \\
\text { Unidos" }\end{array}$ & $\begin{array}{l}\text { o papel educativo em realização } \\
\text { dos museus norte-americanos }\end{array}$ & 8 & 12 & 1952JUL/SET & Lina Bo Bardi \\
\hline arquitetura & sem autoria & "Casa na Bahia" & $\begin{array}{c}\text { texto crítico sobre as } \\
\text { características a arquitetura } \\
\text { moderna brasileira - projeto do } \\
\text { Arq. Antonio Rebouças e Levy } \\
\text { Smarchewski }\end{array}$ & 8 & 16 & 1952JUL/SET & Lina Bo Bardi \\
\hline arquitetura & sem autoria & "Casa em Juiz de Fora" & imagens (fotos Arthur Arcuri) & 8 & 18 & 1952JUL/SET & Lina Bo Bardi \\
\hline arquitetura & $\begin{array}{l}\text { Victor Canongia } \\
\text { Barbosa }\end{array}$ & $\begin{array}{l}\text { "Arborização e paisagismo nas } \\
\text { estradas de rodagem" }\end{array}$ & $\begin{array}{c}\text { as obras que devem } \\
\text { acompanhar a abertura das } \\
\text { novas estrada - o paisagismo } \\
\text { dos trechos laterais para } \\
\text { proteção e embelezamento, e } \\
\text { realizações do DER }\end{array}$ & 8 & 20 & 1952JUL/SET & Lina Bo Bardi \\
\hline arquitetura & sem autoria & "Um estudante em viagem “ & $\begin{array}{l}\text { fotografias de Rachel Esther } \\
\text { ProchniK }\end{array}$ & 8 & 26 & 1952JUL/SET & Lina Bo Bardi \\
\hline artesanato & sem autoria & "A civilização das plumas" & $\begin{array}{c}\text { sobre a importância da arte } \\
\text { plumária nas épocas pré- } \\
\text { históricas }\end{array}$ & 8 & 31 & 1952JUL/SET & Lina Bo Bardi \\
\hline artesanato & sem autoria & "Pluma, elementos de moda" & $\begin{array}{l}0 \text { estudo da ornamentação com } \\
\text { plumas }\end{array}$ & 8 & 32 & 1952JUL/SET & Lina Bo Bardi \\
\hline artesanato & Emilio Villa & $\begin{array}{l}\text { "A arte brasileira num Museu } \\
\text { Romano" }\end{array}$ & $\begin{array}{l}\text { a arte cerâmica (vasos), } \\
\text { como indicativo do grau de } \\
\text { desenvolvimento de uma } \\
\text { civilização e a tecelagem do } \\
\text { povo Amazônico na coleção } \\
\text { Pigorini em Roma }\end{array}$ & 8 & 34 & 1952JUL/SET & Lina Bo Bardi \\
\hline música & sem autoria & $\begin{array}{l}\text { "Nossos instrumentos } \\
\text { musicais" }\end{array}$ & $\begin{array}{l}\text { o legado popular como fonte de } \\
\text { riquezas }\end{array}$ & 8 & 42 & 1952JUL/SET & Lina Bo Bardi \\
\hline música & $\begin{array}{c}\text { Rossini Tavares } \\
\text { de Lima }\end{array}$ & "Peças do Museu Folclórico" & $\begin{array}{l}0 \text { acervo do Centro Folclórico } \\
\text { "Mario de Andrade" }\end{array}$ & 8 & 44 & 1952JUL/SET & Lina Bo Bardi \\
\hline arte & sem autoria & "Pinacoteca do Museu de Arte" & $\begin{array}{l}\text { aquisição pelo museu de dois } \\
\text { Renoir, quatro Delacroix }\end{array}$ & 8 & 46 & 1952JUL/SET & Lina Bo Bardi \\
\hline fotografia & Fran Martins & $\begin{array}{l}\text { "A jangada segundo } \\
\text { Albuquerque" }\end{array}$ & $\begin{array}{c}\text { Fotografias em torno do } \\
\text { tema jangada de Fernando de } \\
\text { Albuquerque, segui do texto de } \\
\text { Fran Martin }\end{array}$ & 8 & 50 & 1952JUL/SET & Lina Bo Bardi \\
\hline fotografia & S. F. & "Coincidências fotográficas" & $\begin{array}{l}\text { ironia com as possíveis } \\
\text { semelhanças impressas pela } \\
\text { fotografia }\end{array}$ & 8 & 58 & 1952JUL/SET & Lina Bo Bardi \\
\hline arte & sem autoria & $\begin{array}{l}\text { "0 Salão nacional de arte } \\
\text { moderna no Rio" }\end{array}$ & $\begin{array}{c}\text { sobre a exposição nacional } \\
\text { de arte moderna dirigida pelo } \\
\text { Patrimônio Histórico e Artístico } \\
\text { Nacional }\end{array}$ & 8 & 59 & 1952JUL/SET & Lina Bo Bardi \\
\hline arte & sem autoria & “Zorilla' & $\begin{array}{l}\text { sobre os desenhos do artista a } \\
\text { ser exposto no Museu }\end{array}$ & 8 & 62 & 1952JUL/SET & Lina Bo Bardi \\
\hline arte & sem autoria & "Arnaldo Pedrosa d'Horta" & histórico do artista & 8 & 65 & 1952JUL/SET & Lina Bo Bardi \\
\hline arte & $\begin{array}{l}\text { A. Pedrosa } \\
\text { d'Horta }\end{array}$ & "Museu entrevistos de avião" & $\begin{array}{l}\text { a tomada de contato com o } \\
\text { extenso acervo dos museus da } \\
\text { Itália e da França }\end{array}$ & 8 & 70 & 1952JUL/SET & Lina Bo Bardi \\
\hline arte & sem autoria & "Novo colecionador" & $\begin{array}{l}\text { Sr. Paulo Robell - de arte } \\
\text { moderna }\end{array}$ & 8 & 71 & 1952JUL/SET & Lina Bo Bardi \\
\hline arte & $\begin{array}{l}\text { Affonso de } \\
\text { Taunay }\end{array}$ & $\begin{array}{c}\text { "Um artista malogrado, A.A. } \\
\text { Taunay (1803-1828) }\end{array}$ & $\begin{array}{c}\text { traz uma carta de } 1827 \text {, escrita } \\
\text { por Affonso de Taunay e um } \\
\text { histórico do artista }\end{array}$ & 8 & 72 & 1952JUL/SET & Lina Bo Bardi \\
\hline
\end{tabular}


ÍNDICE CLASSIFICADO E COMENTADO

\begin{tabular}{|c|c|c|c|c|c|c|c|}
\hline TEMA & AUTOR & TÍTULO & DESCRIÇÃO & HABITAT & PÁG. & DATA & DESCRIÇÃO \\
\hline arquitetura & Emilio Villa & "Uma exposição de Burle Marx" & $\begin{array}{c}\text { a importância da obra artística } \\
\text { e paisagística do artista exposta } \\
\text { no Museu }\end{array}$ & 8 & 76 & 1952JUL/SET & Lina Bo Bardi \\
\hline literatura & Emilio Villa & "Três fábulas dos pretos" & $\begin{array}{l}\text { sobre as formas da prosa } \\
\text { artística primitiva }\end{array}$ & 8 & 80 & 1952JUL/SET & Lina Bo Bardi \\
\hline teatro & sem autoria & "Ruggero Jacobbi" & $\begin{array}{l}\text { biografia e curriculum do diretor } \\
\text { de teatro }\end{array}$ & 8 & 82 & 1952JUL/SET & Lina Bo Bardi \\
\hline teatro & Ruggero Jacobbi & "A temporada francesa" & comentários a cerca do evento & 8 & 84 & 1952JUL/SET & Lina Bo Bardi \\
\hline cinema & G. G. & "Boa qualidade?" & $\begin{array}{l}\text { o cinema nacional e a paisagem } \\
\text { brasileira - a necessidade da } \\
\text { experiência plástica em torno do } \\
\text { material vivo }\end{array}$ & 8 & 84 & 1952JUL/SET & Lina Bo Bardi \\
\hline moda & Ruggero Jacobbi & "Curso de modelos" & no Museu - pela moda brasileira & 8 & 86 & 1952JUL/SET & Lina Bo Bardi \\
\hline música & Ruggero Jacobbi & "Educação" & $\begin{array}{l}\text { crítica a pretensão artística e } \\
\text { a necessidade do ensino da } \\
\text { música }\end{array}$ & 8 & 87 & 1952JUL/SET & Lina Bo Bardi \\
\hline editorial & sem autoria & "Por uma enciclopédia brasileira & $\begin{array}{c}\text { convoca para a realização de } \\
\text { uma "uma completa e original } \\
\text { Enciclopédia Brasileira" }\end{array}$ & 9 & 1 & 19520UT/DEZ & Lina Bo Bardi \\
\hline arquitetura & sem autoria & $\begin{array}{l}\text { "Outras arquiteturas do } \\
\text { Convênio Escolar" }\end{array}$ & $\begin{array}{l}\text { a realização dos edifícios em } \\
\text { tempo recorde (publicação de } 3 \\
\text { projetos) }\end{array}$ & 9 & 4 & 19520UT/DEZ & Lina Bo Bardi \\
\hline arquitetura & sem autoria & $\begin{array}{l}\text { "Teatro Arthur Azevedo na Vila } \\
\text { Clementina" }\end{array}$ & $\begin{array}{l}\text { artigo descritivo com imagens } \\
\text { do edifício e do mural de Clóvis } \\
\text { Gaciano }\end{array}$ & 9 & 8 & 19520UT/DEZ & Lina Bo Bardi \\
\hline arquitetura & sem autoria & "Residência em São Paulo" & $\begin{array}{l}\text { Projeto de Oswaldo Corrêa } \\
\text { Gonçalves - publicação do } \\
\text { projeto e imagens da obra } \\
\text { (painel de C. Graciano) }\end{array}$ & 9 & 9 & 19520UT/DEZ & Lina Bo Bardi \\
\hline arquitetura & sem autoria & "Residência em Santos" & $\begin{array}{l}\text { projeto de Oswaldo Corrêa } \\
\text { Gonçalves - publicação do } \\
\text { projeto e imagens da obra }\end{array}$ & 9 & 11 & 19520UT/DEZ & Lina Bo Bardi \\
\hline arquitetura & sem autoria & "Uma agência de Banco" & $\begin{array}{l}\text { projeto de interiores de } \\
\text { Brancante altera o conceito de } \\
\text { projeto para estabelecimentos } \\
\text { com este fim (painel de Fulvio } \\
\text { Pennacchi) }\end{array}$ & 9 & 12 & 19520UT/DEZ & Lina Bo Bardi \\
\hline arquitetura & sem autoria & “Loja em São Paulo” & $\begin{array}{c}\text { elogio ao emprego das soluções } \\
\text { no projeto de interiores dos } \\
\text { arquitetos Tinoco e Pivatelli } \\
\text { (imagens) }\end{array}$ & 9 & 14 & 19520UT/DEZ & Lina Bo Bardi \\
\hline arquitetura & $\begin{array}{l}\text { atribuído a Lina } \\
\text { Bo Bardi }\end{array}$ & "Construir com simplicidade" & $\begin{array}{l}\text { o risco da arquitetura formalista } \\
\text { que se utiliza do “moderno" para } \\
\text { exacerbações plásticas }\end{array}$ & 9 & 15 & 19520UT/DEZ & Lina Bo Bardi \\
\hline arquitetura & sem autoria & $\begin{array}{l}\text { "A localização do Paço Municipal } \\
\text { de São Paulo" }\end{array}$ & $\begin{array}{l}\text { crítica a escolha do terreno na } \\
\text { Praça das Bandeiras }\end{array}$ & 9 & 16 & 19520UT/DEZ & Lina Bo Bardi \\
\hline arte & Flávio Motta & "Saul Steinberg no Brasil" & $\begin{array}{c}\text { sobre sua formação } \\
\text { democrática em Milão (em meio } \\
\text { a industrialização e as tradições } \\
\text { da antiguidade) e a frutificação } \\
\text { em Nova York }\end{array}$ & 9 & 17 & 19520UT/DEZ & Lina Bo Bardi \\
\hline arte & L. C. & $\begin{array}{l}\text { "Hedda Sterne e suas } \\
\text { máquinas" }\end{array}$ & $\begin{array}{l}\text { o papel da máquina e sua } \\
\text { representação na pintura de } \\
\text { Hedda Sterne }\end{array}$ & 9 & 21 & 19520UT/DEZ & Lina Bo Bardi \\
\hline arte & $\begin{array}{l}\text { Dr. Edu } \\
\text { Machado } \\
\text { Gomes }\end{array}$ & "Psiquiatria e pintura" & $\begin{array}{l}\text { a expressão artística fruto da } \\
\text { relação psiquiatra-paciênte } \\
\text { (experiência c/ Roberto } \\
\text { Sambonet) }\end{array}$ & 9 & 27 & 19520UT/DEZ & Lina Bo Bardi \\
\hline arte & sem autoria & "Novelli, pintor e ceramista" & $\begin{array}{c}\text { influência presente na obra } \\
\text { de Novelli de sua imigração } \\
\text { ao Brasil (pintura e escultura } \\
\text { simplificadas) }\end{array}$ & 9 & 32 & 19520UT/DEZ & Lina Bo Bardi \\
\hline arte & sem autoria & "Homenagem a Segall & $\begin{array}{l}\text { divulgação da publicação do } \\
\text { Museu de Arte escrita por Pietro } \\
\text { Maria Bardi }\end{array}$ & 9 & 34 & 19520UT/DEZ & Lina Bo Bardi \\
\hline artesanato & sem autoria & "Nordeste mágico" & objetos ligados ao candomblé & 9 & 35 & 19520UT/DEZ & Lina Bo Bardi \\
\hline
\end{tabular}


ÍNDICE CLASSIFICADO E COMENTADO

\begin{tabular}{|c|c|c|c|c|c|c|c|}
\hline TEMA & AUTOR & TÍTULO & DESCRIÇÃO & HABITAT & PÁG. & DATA & DESCRIÇÃO \\
\hline museus & sem autoria & $\begin{array}{l}\text { "Outras peças no Museu Pigorini } \\
\text { de Roma" }\end{array}$ & $\begin{array}{l}\text { continuação de artigo - Habitat } \\
\text { 08, sobre o acervo do Museu } \\
\text { Etnográfico Pigorini de Roma. A } \\
\text { importância da preservação de } \\
\text { objetos históricos e artísticos }\end{array}$ & 9 & 36 & 19520UT/DEZ & Lina Bo Bardi \\
\hline fotografia & 0. Tavares & "Imagens da Bahia" & $\begin{array}{l}\text { imagens e texto que enaltece os } \\
\text { diversos aspectos da Bahia }\end{array}$ & 9 & 42 & 19520UT/DEZ & Lina Bo Bardi \\
\hline arquitetura & sem autoria & "Belém" & $\begin{array}{l}\text { um exemplo da espontaneidade } \\
\text { da arquitetura popular }\end{array}$ & 9 & 47 & 19520UT/DEZ & Lina Bo Bardi \\
\hline arquitetura & sem autoria & $\begin{array}{l}\text { "Monumento de outrora e de } \\
\text { agora" }\end{array}$ & $\begin{array}{l}\text { crítica aos temas eleitos e a } \\
\text { representação dos monumentos }\end{array}$ & 9 & 48 & 19520UT/DEZ & Lina Bo Bardi \\
\hline arquitetura & Arthur Arcuri & "Forma e Monumento" & $\begin{array}{c}\text { a questão do monumento } \\
\text { - a simplificação da forma e a } \\
\text { contemplação estética }\end{array}$ & 9 & 49 & 19520UT/DEZ & Lina Bo Bardi \\
\hline cultura & sem autoria & "30 anos" & crítica a intelectualidade & 9 & 50 & 19520UT/DEZ & Lina Bo Bardi \\
\hline museus & sem autoria & "0 que é um museu?" & $\begin{array}{c}\text { o papel educativo dos museus, } \\
\text { cumprido pelo Museu de Arte } \\
\text { de São Paulo (imagens das } \\
\text { diversas atividades) }\end{array}$ & 9 & 52 & 19520UT/DEZ & Lina Bo Bardi \\
\hline arte & sem autoria & $\begin{array}{l}\text { "Pinturas Inglesas, no Museu } \\
\text { de Arte" }\end{array}$ & $\begin{array}{l}\text { Lawrencw, Romney, Reynolds - a } \\
\text { pintura inglesa dos setecentos }\end{array}$ & 9 & 58 & 19520UT/DEZ & Lina Bo Bardi \\
\hline arte & sem autoria & "Les baigmeuses" de Manet & a nova aquisição do MASP & & & 19520UT/DEZ & \\
\hline fotografia & sem autoria & "Fotografia" & $\begin{array}{l}\text { sobre o XI Salão internacional } \\
\text { de Arte Fotográfica - Foto Cine } \\
\text { Clube Bandeirantes }\end{array}$ & 9 & 60 & 19520UT/DEZ & Lina Bo Bardi \\
\hline cinema & sem autoria & "Onde Mora Alberto Cavalcanti" & $\begin{array}{c}\text { imagens da casa de Cavalcanti } \\
\text { - com móveis e objetos trazidos } \\
\text { da Europa (explicitando sua } \\
\text { formação) }\end{array}$ & 9 & 63 & 19520UT/DEZ & Lina Bo Bardi \\
\hline moda & sem autoria & "Problema remoto o da moda" & $\begin{array}{l}\text { a importância da moda - a } \\
\text { construção de uma moda } \\
\text { brasileira e o papel do MASP }\end{array}$ & 9 & 65 & 19520UT/DEZ & Lina Bo Bardi \\
\hline moda & Luiza Sambonet & “Uma moda brasileira & $\begin{array}{l}\text { as primeiras realizações da } \\
\text { moda no MASP }\end{array}$ & 9 & 66 & 19520UT/DEZ & Lina Bo Bardi \\
\hline moda & sem autoria & "Fath no Brasil" & $\begin{array}{c}\text { Homenagem da Casa Vogue a } \\
\text { Jacques Fath e senhora }\end{array}$ & 9 & 67 & 19520UT/DEZ & Lina Bo Bardi \\
\hline moda & sem autoria & "Elementos da moda brasileira" & $\begin{array}{c}\text { imagens de personalidades } \\
\text { fundamentais para } 0 \\
\text { desenvolvimento da moda no } \\
\text { Museu }\end{array}$ & 9 & 68 & 19520UT/DEZ & Lina Bo Bardi \\
\hline moda & sem autoria & "0 curso de modelos" & $\begin{array}{c}\text { divulgação do curso - imagens } \\
\text { das aulas }\end{array}$ & 9 & 69 & 19520UT/DEZ & Lina Bo Bardi \\
\hline moda & sem autoria & $\begin{array}{l}\text { "Tecidos executados no Museu } \\
\text { de Arte" }\end{array}$ & $\begin{array}{c}\text { imagens das criações de Klara } \\
\text { Hartoch, Roberto Sambonet, } \\
\text { Roberto Burle Marx, Carybé }\end{array}$ & 9 & 70 & 19520UT/DEZ & Lina Bo Bardi \\
\hline moda & sem autoria & "Os modelos no desfile" & $\begin{array}{c}\text { desenhos de figurinos } \\
\text { desenhados por Sambonet, } \\
\text { confeccionados pelo MASP e } \\
\text { com apresentação no Mappin }\end{array}$ & 9 & 72 & 19520UT/DEZ & Lina Bo Bardi \\
\hline moda & sem autoria & "Sapatos e chapéus" & $\begin{array}{c}\text { mostra crítica da moda } \\
\text { com característica nacional } \\
\text { apresentada em desfile no } \\
\text { MASP, desenho de Sambonet }\end{array}$ & 9 & 76 & 19520UT/DEZ & Lina Bo Bardi \\
\hline moda & sem autoria & "0 desfile no Museu" & $\begin{array}{c}\text { primeiro desfile de moda } \\
\text { brasileira, no MASP (imagens } \\
\text { do desfile) }\end{array}$ & 9 & 78 & 19520UT/DEZ & Lina Bo Bardi \\
\hline $\begin{array}{l}\text { desenho } \\
\text { industrial }\end{array}$ & sem autoria & "Artesanato e industria" & $\begin{array}{l}\text { a necessidade de artistas para } \\
\text { trabalhar na indústria }\end{array}$ & 9 & 86 & 19520UT/DEZ & Lina Bo Bardi \\
\hline $\begin{array}{l}\text { desenho } \\
\text { industrial }\end{array}$ & sem autoria & "Uma mesa de armar" & um projeto de Arthur Arcuri & 9 & 87 & 19520UT/DEZ & Lina Bo Bardi \\
\hline editorial & $\begin{array}{l}\text { Assis } \\
\text { Chateaubriand }\end{array}$ & "Problemas educacionais" & $\begin{array}{c}\text { discurso proferido por } \\
\text { Chateaubriand em reunião em } \\
\text { prol da criação de "uma, Groton } \\
\text { Scholl, alternada com a École de } \\
\text { Roches" no Brasil. }\end{array}$ & 10 & 1 & 1953JAN/MAR & Flávio Motta \\
\hline
\end{tabular}


ÍNDICE CLASSIFICADO E COMENTADO

\begin{tabular}{|c|c|c|c|c|c|c|c|}
\hline TEMA & AUTOR & TÍTULO & DESCRIÇÃO & HABITAT & PÁG. & DATA & DESCRIÇÃO \\
\hline arquitetura & Flávio Motta & "São Paulo e o ‘art nouveau'” & $\begin{array}{l}\text { a importância do estudo do "art } \\
\text { nouveau" em São Paulo e do } \\
\text { equivoco dos historiadores ao } \\
\text { superestimarem o Barroco }\end{array}$ & 10 & 3 & 1953JAN/MAR & Flávio Motta \\
\hline $\begin{array}{l}\text { arquitetura - } \\
\text { projeto }\end{array}$ & sem autoria & $\begin{array}{c}\text { "Prédio de apartamentos em } \\
\text { São Paulo" }\end{array}$ & $\begin{array}{c}\text { projeto de Giancarlo Palanti, } \\
\text { para edifício residencial de nove } \\
\text { andares na Rua Barão de Tatuí. } \\
\text { Painel de Sambonet }\end{array}$ & 10 & 19 & 1953JAN/MAR & Flávio Motta \\
\hline $\begin{array}{l}\text { arquitetura - } \\
\text { projeto }\end{array}$ & sem autoria & "Arquitetura industrial" & $\begin{array}{l}\text { atribui a racionalização da } \\
\text { arquitetura às experiências de } \\
\text { Bherens e dos alemães, como } \\
\text { exemplo a fábrica da "Arno" de } \\
\text { Rino Levi }\end{array}$ & 10 & 25 & 1953JAN/MAR & Flávio Motta \\
\hline urbanismo & sem autoria & $\begin{array}{l}\text { "0 Jardim Morumbi: arquitetura- } \\
\text { natureza" }\end{array}$ & $\begin{array}{c}\text { o sucesso do novo bairro, } \\
\text { diferenciado pela incorporação } \\
\text { dos elementos naturais da } \\
\text { paisagem e da completa infra- } \\
\text { estrutura }\end{array}$ & 10 & 27 & 1953JAN/MAR & Flávio Motta \\
\hline $\begin{array}{l}\text { arquitetura - } \\
\text { projeto }\end{array}$ & Lina Bo Bardi & "Residência no Morumbi" & $\begin{array}{c}\text { descrição das intenções -"situar } \\
\text { a casa na natureza, sem se } \\
\text { preocupar com as 'proteções' } \\
\text { usuais" - e das soluções } \\
\text { técnicas }\end{array}$ & 10 & 31 & 1953JAN/MAR & Flávio Motta \\
\hline $\begin{array}{l}\text { arquitetura - } \\
\text { projeto }\end{array}$ & Oswaldo Bratke & “Outra residência no Morumbi” & $\begin{array}{c}\text { a zoneamento em diurno, } \\
\text { noturno serviço e a flexibilidade } \\
\text { da planta }\end{array}$ & 10 & 41 & 1953JAN/MAR & Flávio Motta \\
\hline $\begin{array}{l}\text { arquitetura - } \\
\text { projeto }\end{array}$ & sem autoria & $\begin{array}{l}\text { "O Colégio Paraguay-Brasil em } \\
\text { Assunção" }\end{array}$ & $\begin{array}{l}\text { Projeto de Affonso Reidy, } \\
\text { em Assunção, do Colégio } \\
\text { Experimental doado pelo } \\
\text { Governo Brasileiro ao Governo } \\
\text { Paraguaio }\end{array}$ & 10 & 45 & 1953JAN/MAR & Flávio Motta \\
\hline arquitetura & $\begin{array}{l}\text { atribuído a Lina } \\
\text { Bo Bardi }\end{array}$ & "0 povo é arquiteto" & $\begin{array}{c}\text { referência a arquitetura popular, } \\
\text { como argumento imagens } \\
\text { do escultor Zamoisky de um } \\
\text { exemplar em Prestemé, Estado } \\
\text { do Rio }\end{array}$ & 10 & 52 & 1953JAN/MAR & Flávio Motta \\
\hline arquitetura & Leon Kochnitzky & $\begin{array}{c}\text { "Barroco português e brasileiro } \\
\text { na Africa Central" }\end{array}$ & $\begin{array}{c}\text { a presença destas influencias à } \\
\text { partir da colonização e do tráfico } \\
\text { de escravos }\end{array}$ & 10 & 53 & 1953JAN/MAR & Flávio Motta \\
\hline arte & Armando Cunha “ & "Salvar e conservar as imagens" & $\begin{array}{c}\text { Com o abandono e a } \\
\text { comercialização da arte sacra } \\
\text { pela igreja, resta aos mecenas } \\
\text { salvá-las }\end{array}$ & 10 & 56 & 1953JAN/MAR & Flávio Motta \\
\hline arte & sem autoria & "Abstratos" & $\begin{array}{l}\text { a riqueza da abstração das } \\
\text { obras infantis }\end{array}$ & 10 & 61 & 1953JAN/MAR & Flávio Motta \\
\hline arte & sem autoria & "El Greco e o Museu de Arte" & $\begin{array}{l}\text { a aquisiç̧ão pelo MASP da } \\
\text { "Anunciação" }\end{array}$ & 10 & 62 & 1953JAN/MAR & Flávio Motta \\
\hline arte & sem autoria & $\begin{array}{c}\text { "Outra tela de Van Gogh para o } \\
\text { Museu" }\end{array}$ & $\begin{array}{l}\text { a aquisiçãa pelo MASP da } \\
\text { "Passeio a tarde" }\end{array}$ & 10 & 64 & 1953JAN/MAR & Flávio Motta \\
\hline museus & sem autoria & $\begin{array}{l}\text { "Projeto das exposições } \\
\text { didáticas do Museu de Arte. A } \\
\text { arte assim chamada moderna" }\end{array}$ & $\begin{array}{l}\text { exposições que visam através } \\
\text { da história da arte, esclarecer } \\
\text { a história da humanidade nos } \\
\text { últimos séculos }\end{array}$ & 10 & 66 & 1953JAN/MAR & Flávio Motta \\
\hline propaganda & sem autoria & "Cartazes" & $\begin{array}{l}\text { a seriedade conquistada pela } \\
\text { propaganda, onde destacam-se } \\
\text { jovens talentos formados pelo } \\
\text { Museu de Arte. Wollner, Virgínia } \\
\text { Bergamaschi e Virgílio Costa } \\
\text { Neto. }\end{array}$ & 10 & 70 & 1953JAN/MAR & Flávio Motta \\
\hline arte & sem autoria & "Pintura no Saps" & $\begin{array}{c}\text { exposição e debate em torno } \\
\text { da natureza-morta, organizado } \\
\text { pelo Saps }\end{array}$ & 10 & 71 & 1953JAN/MAR & Flávio Motta \\
\hline arte & sem autoria & "Pintura em Araraquara" & $\begin{array}{c}\text { a surpreendente mostra } \\
\text { no Museu de Arte de telas } \\
\text { "modernas" de autores } \\
\text { formados na Escola de Belas } \\
\text { Artes de Araraquara. Elogios ao } \\
\text { ensino oficial. }\end{array}$ & 10 & 72 & 1953JAN/MAR & Flávio Motta \\
\hline
\end{tabular}


ÍNDICE CLASSIFICADO E COMENTADO

\begin{tabular}{|c|c|c|c|c|c|c|c|}
\hline TEMA & AUTOR & TÍTULO & DESCRIÇÃO & HABITAT & PÁG. & DATA & DESCRIÇÃO \\
\hline arte & sem autoria & "Outro primitivo" & $\begin{array}{c}\text { exposição, no Museu de Arte, } \\
\text { do maestro Zacharias Autuori, } \\
\text { regente da Orquestra do } \\
\text { Municipal }\end{array}$ & 10 & 73 & 1953JAN/MAR & Flávio Motta \\
\hline arte & sem autoria & "0 escultor de Marchis" & $\begin{array}{c}\text { divulgação do diretor da escola } \\
\text { de cerâmica do MASP }\end{array}$ & 10 & 75 & 1953JAN/MAR & Flávio Motta \\
\hline propaganda & Armando Cunha & "Problemas da vitrina" & $\begin{array}{l}\text { a necessidade de um } \\
\text { profissional artista para } \\
\text { execução de vitrinas }\end{array}$ & 10 & 76 & 1953JAN/MAR & Flávio Motta \\
\hline arte & sem autoria & "Novas cerâmicas" & $\begin{array}{l}\text { o espaço conquistado pela } \\
\text { cerâmica em São Paulo, a } \\
\text { qual fundamenta o estudo das } \\
\text { formas modernas a serem } \\
\text { aplicadas nos objetos de uso } \\
\text { diário }\end{array}$ & 10 & 78 & 1953JAN/MAR & Flávio Motta \\
\hline fotografia & sem autoria & "Um fotógrafo" & $\begin{array}{l}\text { divulgação do trabalho de } \\
\text { Aloysius documentando uma } \\
\text { viagem a Creta }\end{array}$ & 10 & 80 & 1953JAN/MAR & Flávio Motta \\
\hline cinema & sem autoria & "Canto do mar, de Cavalcanti" & $\begin{array}{l}\text { sobre as gravações de "Canto } \\
\text { do mar" no Recife }\end{array}$ & 10 & 82 & 1953JAN/MAR & Flávio Motta \\
\hline cinema & sem autoria & "Magia verde" & $\begin{array}{c}\text { documentário colorido sobre o } \\
\text { Brasil "Magia Verde", idealizado } \\
\text { por Leonardo Bonzi, Mario } \\
\text { Craveri, Gian Gaspari Napolitano } \\
\text { e Giovanni Raffaldi e Pietro } \\
\text { Maria Bardi }\end{array}$ & 10 & 84 & 1953JAN/MAR & Flávio Motta \\
\hline cinema & $\begin{array}{c}\text { Florentino } \\
\text { Barbosa e Silva }\end{array}$ & "Os salvadores" & $\begin{array}{c}\text { crítica aos que criticam os que } \\
\text { fazem cinema no Brasil - tarefa } \\
\text { tão difícil }\end{array}$ & 10 & 86 & 1953JAN/MAR & Flávio Motta \\
\hline música & sem autoria & "0 'Angelicum'” & $\begin{array}{c}\text { criação do núcleo de musica } \\
\text { que pretende levar música } \\
\text { as fábricas, aos operários, } \\
\text { aproximando Vivaldi e Bach do } \\
\text { povo }\end{array}$ & 10 & 86 & 1953JAN/MAR & Flávio Motta \\
\hline bailado & sem autoria & "25 anos de Oleneva" & $\begin{array}{c}\text { a importância da bailarina Maria } \\
\text { Oleneva que desde de } 1927 \\
\text { dirige a escola de bailado da } \\
\text { Prefeitura do Rio de Janeiro }\end{array}$ & 10 & 87 & 1953JAN/MAR & Flávio Motta \\
\hline bailado & sem autoria & "Girassol Ambicioso" & $\begin{array}{l}\text { espetáculo de encerramento } \\
\text { do curso de } 1952 \text { do Bailado } \\
\text { Infantil do Museu de Arte. } \\
\text { Imagens do figurino de Jenny } \\
\text { K. Segall }\end{array}$ & 10 & 90 & 1953JAN/MAR & Flávio Motta \\
\hline editorial & sem autoria & "Juventude desesperada" & $\begin{array}{c}\text { sobre a decadência do nível } \\
\text { educacional nas escolas } \\
\text { brasileiras }\end{array}$ & 11 & 1 & 1953ABR/JUN & Flávio Motta \\
\hline arquitetura & sem autoria & "Ibirapuera" & $\begin{array}{l}\text { crítica ao edifício (ainda em } \\
\text { obras) que seria a sede das } \\
\text { exposições comemorativas do } \\
\text { IV Centenário, um pavilhão de } \\
50 \times 200 \text { m com uma "floresta" } \\
\text { de pilares }\end{array}$ & 11 & 3 & 1953ABR/JUN & Flávio Motta \\
\hline $\begin{array}{l}\text { arquitetura - } \\
\text { projeto }\end{array}$ & sem autoria & "Piscina Coberta" & $\begin{array}{c}\text { Projeto do Arq. Icaro de Castro } \\
\text { Mello no Parque da Água } \\
\text { Branca, com cobertura em } \\
\text { abóbada realizada através de } \\
\text { arcos parabólicos em concreto } \\
\text { armado } \\
\text { armado }\end{array}$ & 11 & 4 & 1953ABR/JUN & Flávio Motta \\
\hline $\begin{array}{l}\text { arquitetura - } \\
\text { projeto }\end{array}$ & sem autoria & "Setor residencial do Estudante" & $\begin{array}{l}\text { Projeto do Arq. Rino Levi para } \\
\text { a Cidade universitário de São } \\
\text { Paulo }\end{array}$ & 11 & 7 & 1953ABR/JUN & Flávio Motta \\
\hline arquitetura & Rino Levi & "Planejamento de Hospitais" & $\begin{array}{l}\text { curso ministrado pelo Arq. } \\
\text { Rino Levi e realizado no IAB, } \\
\text { presidido pelo arquiteto }\end{array}$ & 11 & 10 & 1953ABR/JUN & Flávio Motta \\
\hline $\begin{array}{l}\text { arquitetura - } \\
\text { projeto }\end{array}$ & sem autoria & "Estádio em São Paulo" & $\begin{array}{l}\text { Projeto do Arq. Villanova Artigas } \\
\text { - imagem da maquete, desenhos } \\
\text { realizados para o concurso } \\
\text { vencedor }\end{array}$ & 11 & 12 & 1953ABR/JUN & Flávio Motta \\
\hline
\end{tabular}


ÍNDICE CLASSIFICADO E COMENTADO

\begin{tabular}{|c|c|c|c|c|c|c|c|}
\hline TEMA & AUTOR & TÍTULO & DESCRIÇÃO & HABITAT & PÁG. & DATA & DESCRIÇÃO \\
\hline arquitetura & sem autoria & "Duas Grandes Lojas" & $\begin{array}{l}\text { Maquete do projeto de ocupação } \\
\text { das lojas Mesbla S.A. (Rio } \\
\text { de Janeiro) e Mappin, ambos } \\
\text { realizados pela Itart Decorações. }\end{array}$ & 11 & 14 & 1953ABR/JUN & Flávio Motta \\
\hline arquitetura & sem autoria & "Outras Lojas" & $\begin{array}{l}\text { Imagens de interiores de lojas } \\
\text { e conceitos importantes que } \\
\text { orientaram o projeto }\end{array}$ & 11 & 15 & 1953ABR/JUN & Flávio Motta \\
\hline arquitetura * & sem autoria & "Materiais Novos" & $\begin{array}{c}\text { a utilização da fibra de vidro } \\
\text { na construção civil para a } \\
\text { montagem de pisos flutuantes }\end{array}$ & 11 & 17 & 1953ABR/JUN & Flávio Motta \\
\hline arte & sem autoria & $\begin{array}{c}\text { "Os afrescos da Igreja de } \\
\text { Batatais" }\end{array}$ & $\begin{array}{l}\text { Os afrescos realizados por } \\
\text { Portinari na Igreja de Batatais - } \\
\text { ilustrações e detalhes da obra }\end{array}$ & 11 & 18 & 1953ABR/JUN & Flávio Motta \\
\hline arte & sem autoria & "Yolanda na Bahia" & $\begin{array}{l}\text { a importância de artistas jovens } \\
\text { retratarem as características do } \\
\text { seu pais, como Yolanda Mohaly }\end{array}$ & 11 & 23 & 1953ABR/JUN & Flávio Motta \\
\hline arte & sem autoria & "Pintura de Plattner" & $\begin{array}{c}\text { o percurso do artista Carlo } \\
\text { Pattner antes de sua chegada ao } \\
\text { Brasil e as influencias que este } \\
\text { revela. }\end{array}$ & 11 & 24 & 1953ABR/JUN & Flávio Motta \\
\hline arte & sem autoria & "Volta de Marina de Paris" & $\begin{array}{c}\text { depois de dois anos Marina } \\
\text { Caram retorna de viagem com } \\
\text { uma exposição de gravuras no } \\
\text { MASP }\end{array}$ & 11 & 26 & 1953ABR/JUN & Flávio Motta \\
\hline arte & sem autoria & “Desenhista na Itália” & $\begin{array}{l}\text { divulgação dos desenhos do } \\
\text { jovem artista Francisco Cuoco }\end{array}$ & 11 & 28 & 1953ABR/JUN & Flávio Motta \\
\hline arte & sem autoria & "Pintora alemã no Paraná" & $\begin{array}{c}\text { divulgação dos desenhos } \\
\text { expressionistas da artista } \\
\text { Marianne Overbeck } \\
\end{array}$ & 11 & 29 & & \\
\hline propaganda & sem autoria & "Badia Vilato" & $\begin{array}{l}\text { exposição no MASP do artista } \\
\text { de cartazes francês }\end{array}$ & 11 & 30 & 1953ABR/JUN & Flávio Motta \\
\hline fotografia & sem autoria & "Detalhes de Ouro Preto" & $\begin{array}{l}\text { fotografias de detalhes da } \\
\text { cidade de Ouro Preto sob o olhar } \\
\text { de Lise Modern }\end{array}$ & 11 & 31 & 1953ABR/JUN & Flávio Motta \\
\hline arte & sem autoria & "Paliteiros numa coleção" & $\begin{array}{c}\text { a importância dos } \\
\text { colecionadores para a } \\
\text { conservação do patrimônio } \\
\text { artístico e humano, destaque a } \\
\text { coleção de Osvaldo Riso } \\
\end{array}$ & 11 & 33 & 1953ABR/JUN & Flávio Motta \\
\hline arte & sem autoria & Inéditos do Rio" & $\begin{array}{c}\text { obras inéditas de artistas } \\
\text { europeus que no séc. XIX } \\
\text { retrataram o Brasil - Louis Czerni } \\
\text { e Etienne François Mayer }\end{array}$ & 11 & 36 & 1953ABR/JUN & Flávio Motta \\
\hline arte & $\begin{array}{l}\text { Affonso de } \\
\text { Taunay }\end{array}$ & $\begin{array}{l}\text { "Outras aventuras de um artista } \\
\text { mologrado" }\end{array}$ & $\begin{array}{c}\text { transcrição da carta de A. } \\
\text { Adriano Taunay na qual descreve } \\
\text { o abandono de Mato Grosso } \\
\text { com a transferência do governo } \\
\text { para Cuiabá e outra em que Luiz } \\
\text { Riedel comunica a morte do } \\
\text { amigo A. Taunay }\end{array}$ & 11 & 38 & 1953ABR/JUN & Flávio Motta \\
\hline fotografia & sem autoria & "Álbum de fotografias" & $\begin{array}{c}\text { publicação de álbum de } \\
\text { fotografias anônimo encontrado } \\
\text { que retrata a sociedade nos } \\
\text { primeiros anos da República }\end{array}$ & 11 & 44 & 1953ABR/JUN & Flávio Motta \\
\hline arte & sem autoria & "Um restaurador" & $\begin{array}{l}\text { contratação pelo MASP do } \\
\text { restaurador moldurista Georg } \\
\text { Sprengel }\end{array}$ & 11 & 48 & 1953ABR/JUN & Flávio Motta \\
\hline arte & Flávio Motta & “A época do 'Span'” & $\begin{array}{c}\text { sociedade de artistas modernos, } \\
\text { em São Paulo entre } 1932 \text { e } 34 \\
\text { - as personalidades envolvidas } \\
\text { e as atividades que marcaram } \\
\text { a época } \\
\end{array}$ & 11 & 49 & 1953ABR/JUN & Flávio Motta \\
\hline arte & Flávio Motta & "Intercambio com Pellizzari” & $\begin{array}{l}\text { industrial italiano que aproxima } \\
\text { a arte de seus trabalhadores, } \\
\text { alterando as relações entre } \\
\text { capital e trabalho }\end{array}$ & 11 & 61 & 1953ABR/JUN & Flávio Motta \\
\hline
\end{tabular}


ÍNDICE CLASSIFICADO E COMENTADO

\begin{tabular}{|c|c|c|c|c|c|c|c|}
\hline TEMA & AUTOR & TÍTULO & DESCRIÇÃO & HABITAT & PÁG. & DATA & DESCRIÇÃO \\
\hline & Bernabó & "A alma do capoeirista" & $\begin{array}{c}\text { sobre a importância da capoeira } \\
\text { de angola - a dança, a música e } \\
\text { a religião na cultura baiano }\end{array}$ & 11 & 62 & 1953ABR/JUN & Flávio Motta \\
\hline arte & $\begin{array}{l}\text { R. Frontini de } \\
\text { Borba }\end{array}$ & "Mario Cravo" & $\begin{array}{c}\text { a importância de conhecer de } \\
\text { estudar as origens para realizar } \\
\text { a arte dita internacional }\end{array}$ & 11 & 65 & 1953ABR/JUN & Flávio Motta \\
\hline artesanato & sem autoria & "Os ladrões de ex-votos" & $\begin{array}{l}\text { a influencia da arte popular } \\
\text { na obra de Mário Cravo, } \\
\text { colecionador de ex-votos }\end{array}$ & 11 & 67 & 1953ABR/JUN & Flávio Motta \\
\hline arte & sem autoria & "Bandeirantes" & $\begin{array}{l}\text { detalhes do Monumento às } \\
\text { Bandeiras de Victor Brecheret }\end{array}$ & 11 & 72 & 1953ABR/JUN & Flávio Motta \\
\hline arte & sem autoria & $\begin{array}{c}\text { "Metamorfose e escultura de } \\
\text { plantas" }\end{array}$ & $\begin{array}{l}\text { o surrealismo presente na obra } \\
\text { de Walter Lewy e a inspiração } \\
\text { em seu jardim de cactus }\end{array}$ & 11 & 74 & 1953ABR/JUN & Flávio Motta \\
\hline arte & sem autoria & "A escultora Sonja Ebling" & $\begin{array}{c}\text { divulgação da obra da escultura } \\
\text { autodidata e comentários a } \\
\text { cerca da obra }\end{array}$ & 11 & 76 & 1953ABR/JUN & Flávio Motta \\
\hline $\begin{array}{l}\text { desenho } \\
\text { industrial }\end{array}$ & sem autoria & "Tecidos decorativos" & $\begin{array}{l}\text { a "descoberta" dos elementos } \\
\text { nacionais na indústria de tecidos } \\
\text { decorativos }\end{array}$ & 11 & 79 & 1953ABR/JUN & Flávio Motta \\
\hline propaganda & Flávio Motta & $\begin{array}{l}\text { "A primeira turma da Escola de } \\
\text { Propaganda" }\end{array}$ & $\begin{array}{c}\text { coincide com a formatura da } \\
\text { primeira turma a viagem de } \\
\text { especialização à Inglaterra de } \\
\text { Rodolfo Lima Martesen, diretor } \\
\text { da Escola de Propaganda do } \\
\text { MASP } \\
\end{array}$ & 11 & 81 & 1953ABR/JUN & Flávio Motta \\
\hline teatro & $\begin{array}{l}\text { Abdias } \\
\text { Nascimento }\end{array}$ & $\begin{array}{l}\text { "Uma experiência social e } \\
\text { estética" }\end{array}$ & $\begin{array}{c}\text { sobre o Teatro Experimental do } \\
\text { Negro, agora com } 0 \text { apoio do } \\
\text { MASP }\end{array}$ & 11 & 82 & 1953ABR/JUN & Flávio Motta \\
\hline cinema & $\begin{array}{l}\text { F. Barbosa e } \\
\text { Silva }\end{array}$ & $\begin{array}{l}\text { "Propósitos e despropósitos de } \\
\text { Lima Barreto" }\end{array}$ & $\begin{array}{c}\text { entrevista com o cineasta sobre } \\
\text { o filme "0 Cangaceiro" }\end{array}$ & 11 & 85 & 1953ABR/JUN & Flávio Motta \\
\hline bailado & sem autoria & "Valery Oeser" & $\begin{array}{l}\text { bailarina expressionista, de } \\
\text { origem austríaca que interpretou } \\
\text { "Amazonas" de Villa Lobos }\end{array}$ & 11 & 88 & 1953ABR/JUN & Flávio Motta \\
\hline editorial & Flávio Motta & "Um lift para Paris" & $\begin{array}{l}\text { o empréstimo de obras do } \\
\text { MASP para exposição em Paris } \\
\text { no Musée de l'Örangerie }\end{array}$ & 12 & 1 & 1953JUL/SET & Flávio Motta \\
\hline urbanismo & sem autoria & "Querido Sr. Urbanista" & $\begin{array}{l}\text { apelo aos urbanistas por uma } \\
\text { São Paulo planejada, onde os } \\
\text { especuladores imobiliários } \\
\text { sejam contidos, a população } \\
\text { seja assistida pelo saneamento } \\
\text { básico, etc } \\
\text {. }\end{array}$ & 12 & 2 & 1953JUL/SET & Flávio Motta \\
\hline arquitetura & sem autoria & "Uma nota de 'Interiors'” & $\begin{array}{c}\text { transcrição de artigo elogioso } \\
\text { publicado na revista 'Interiors' } \\
\text { sobre o projeto da residência } \\
\text { da arquiteto Lina Bo Bardi no } \\
\text { Morumbi }\end{array}$ & 12 & 5 & 1953JUL/SET & Flávio Motta \\
\hline arquitetura & sem autoria & "Dois Monumentos" & $\begin{array}{c}\text { estudo de monumentos } \\
\text { modernos. Um de Hélio Duarte } \\
\text { e Mangue a Rui Barbosa e outro } \\
\text { do estudante Eduardo Rosso } \\
\text { a F.E.B. }\end{array}$ & 12 & 6 & 1953JUL/SET & Flávio Motta \\
\hline $\begin{array}{l}\text { arquitetura - } \\
\text { projeto }\end{array}$ & Flávio Motta & "Prédio em Campinas" & $\begin{array}{l}\text { projeto do arquiteto Oscar } \\
\text { Niemeyer - Edifício Itatiaia } \\
\text { (residencial) }\end{array}$ & 12 & 9 & 1953JUL/SET & Flávio Motta \\
\hline $\begin{array}{l}\text { arquitetura - } \\
\text { projeto }\end{array}$ & Flávio Motta & "Prédio ‘Nações Unidas'” & $\begin{array}{l}\text { projeto do arquiteto Abelardo de } \\
\text { Souza - Edifício Nações Unidas } \\
\text { (residencial) }\end{array}$ & 12 & 10 & 1953JUL/SET & Flávio Motta \\
\hline arquitetura & Flávio Motta & "0 arq. Milton Roberto" & $\begin{array}{c}\text { artigo que notifica o falecimento } \\
\text { do autor de importantes obras } \\
\text { que marcaram a arquitetura } \\
\text { moderna no Rio de Janeiro }\end{array}$ & 12 & 12 & 1953JUL/SET & Flávio Motta \\
\hline $\begin{array}{l}\text { arquitetura - } \\
\text { projeto }\end{array}$ & $\begin{array}{l}\text { Carlos Henrique } \\
\text { Porto }\end{array}$ & "O hospital do I.A.P.E.T.C." & $\begin{array}{c}0 \text { artigo expõe a complexidade } \\
\text { e a eficiência das soluções para } \\
\text { atender ao programa de um } \\
\text { hospital }\end{array}$ & 12 & 13 & 1953JUL/SET & Flávio Motta \\
\hline
\end{tabular}


ÍNDICE CLASSIFICADO E COMENTADO

\begin{tabular}{|c|c|c|c|c|c|c|c|}
\hline TEMA & AUTOR & TÍTULO & DESCRIÇÃO & HABITAT & PÁG. & DATA & DESCRIÇÃO \\
\hline $\begin{array}{l}\text { arquitetura - } \\
\text { projeto }\end{array}$ & $\begin{array}{l}\text { L. A. Falcão } \\
\text { Bauer }\end{array}$ & "Três escolas do Senai" & $\begin{array}{c}\text { divulgação do projeto da Escola } \\
\text { de Bauru - Roberto Tibau, da } \\
\text { Vila Mariana e a Escola Textil } \\
\text { - Hélio Duarte e Mangue }\end{array}$ & 12 & 16 & 1953JUL/SET & Flávio Mota \\
\hline $\begin{array}{l}\text { arquitetura - } \\
\text { projeto }\end{array}$ & Gio Ponti & "Edifício de Física Nuclear" & $\begin{array}{l}\text { no Campus da Universidade } \\
\text { de São Paulo, o arquiteto Gio } \\
\text { Ponti faz da arquitetura uma } \\
\text { homenagem ao seu pais de } \\
\text { origem - a Itália }\end{array}$ & 12 & 20 & 1953JUL/SET & Flávio Motta \\
\hline $\begin{array}{l}\text { arquitetura - } \\
\text { projeto }\end{array}$ & $\begin{array}{l}\text { Vaidergorn e } \\
\text { Verona }\end{array}$ & "Casa sobre pedras" & Projeto residencial no Guarujá & 12 & 26 & 1953JUL/SET & Flávio Motta \\
\hline $\begin{array}{l}\text { arquitetura - } \\
\text { projeto }\end{array}$ & sem autoria & "Arquitetura do litoral" & $\begin{array}{l}\text { Imagem da residência do Eng. } \\
\text { Leonidas Albuquerque, marcada } \\
\text { pela despretensão }\end{array}$ & 12 & 27 & 1953JUL/SET & Flávio Motta \\
\hline arquitetura & sem autoria & "Residência" & $\begin{array}{l}\text { imagens externas da residência } \\
\text { projetada pelo escritório } \\
\text { Bernardo Rzezák }\end{array}$ & 12 & 27 & 1953JUL/SET & Flávio Motta \\
\hline $\begin{array}{l}\text { arquitetura - } \\
\text { projeto }\end{array}$ & sem autoria & "Um centro esportivo" & $\begin{array}{l}\text { projeto de Abelardo de Souza } \\
\text { para a Sede social de Cruzeiro } \\
\text { F.B.C. }\end{array}$ & 12 & 28 & 1953JUL/SET & Flávio Motta \\
\hline $\begin{array}{l}\text { arquitetura - } \\
\text { projeto }\end{array}$ & sem autoria & "Nova fábrica em Jacareí" & $\begin{array}{c}\text { projeto de Rácz Construtora } \\
\text { Ltda. }\end{array}$ & 12 & 29 & 1953JUL/SET & Flávio Motta \\
\hline $\begin{array}{l}\text { arquitetura - } \\
\text { projeto }\end{array}$ & sem autoria & "Igreja no Interior" & $\begin{array}{l}\text { a necessidade da atuação no } \\
\text { interior do estado de arquitetos } \\
\text { jovens, como o projeto de Zenon } \\
\text { Lotufo apresentado. }\end{array}$ & 12 & 30 & 1953JUL/SET & Flávio Motta \\
\hline $\begin{array}{l}\text { arquitetura - } \\
\text { projeto }\end{array}$ & sem autoria & $\begin{array}{c}\text { Uma colônia de férias da } \\
\text { Associação Brasileira dos } \\
\text { Radialistas, no Est. Do Rio" }\end{array}$ & $\begin{array}{c}\text { projeto de Helmut } \\
\text { Braunschweiger e V. Zaremba , } \\
\text { com previsão de construção em } \\
\text { três fases independentes }\end{array}$ & 12 & 33 & 1953JUL/SET & Flávio Motta \\
\hline $\begin{array}{l}\text { arquitetura - } \\
\text { documento }\end{array}$ & Flávio d’Aquino & $\begin{array}{l}\text { "Max Bill, o inteligente } \\
\text { iconoclasta" }\end{array}$ & $\begin{array}{c}\text { entrevista a Flávio d’Aquino, } \\
\text { onde Max Bill critica a } \\
\text { arquitetura moderna brasileira }\end{array}$ & 12 & 34 & 1953JUL/SET & Flávio Motta \\
\hline $\begin{array}{l}\text { desenho } \\
\text { industrial }\end{array}$ & sem autoria & "Nova poltrona" & $\begin{array}{c}\text { desenhada por Lina Bo Bardi e } \\
\text { em duas partes. Referencia ao } \\
\text { texto de Frei Lodoli publicado } \\
\text { em Habitat } 1\end{array}$ & 12 & 36 & 1953JUL/SET & Flávio Motta \\
\hline arquitetura & $\begin{array}{c}\text { A. P. de } \\
\text { Albuquerque }\end{array}$ & "Arq. Antônio José Landi" & $\begin{array}{l}\text { destaca a importância da obra } \\
\text { deixada em Belém do Pará pelo } \\
\text { arquiteto português à serviço } \\
\text { da corte na primeira metade do } \\
\text { séc. XVIII }\end{array}$ & 12 & 38 & 1953JUL/SET & Flávio Motta \\
\hline arte & $\begin{array}{c}\text { A. P. de } \\
\text { Albuquerque }\end{array}$ & "Galeria: Frederico Barata" & $\begin{array}{l}\text { a importância da crítica de } \\
\text { arte exercida por Barata e } \\
\text { sua atuação quase como } \\
\text { antropólogo no que se refere ao } \\
\text { estudo da arte marajoara }\end{array}$ & 12 & 43 & 1953JUL/SET & Flávio Motta \\
\hline arte & René Thiollier & $\begin{array}{l}\text { Depoimento sobre a "Semana } \\
\text { de Arte Moderna" }\end{array}$ & $\begin{array}{l}\text { no qual René Thiollier, através } \\
\text { da transcrição de artigos de } \\
\text { jornal e cartas "prova" sua } \\
\text { importância para a realização da } \\
\text { Semana de Arte Moderna }\end{array}$ & 12 & 44 & 1953JUL/SET & Flávio Motta \\
\hline artesanato & R. F. de Borba & $\begin{array}{l}\text { Roupa de couro do vaqueiro } \\
\text { nordestino }\end{array}$ & $\begin{array}{l}\text { o traje de vaqueiro como uma } \\
\text { manifestação da arte popular } \\
\text { e as condicionantes que a } \\
\text { influenciam }\end{array}$ & 12 & 50 & 1953JUL/SET & Flávio Motta \\
\hline arte & $\begin{array}{l}\text { Pietro Maria } \\
\text { Bardi }\end{array}$ & "0 antigo e nós" & $\begin{array}{l}\text { a necessidade da valorização do } \\
\text { "antigo" }\end{array}$ & 12 & 57 & 1953JUL/SET & Flávio Motta \\
\hline arquitetura & Flávio Motta & "Floreal” & $\begin{array}{c}\text { campanha pela conservação } \\
\text { dos poucos exemplares da } \\
\text { arquitetura 'floreal' existentes } \\
\text { em São Paulo. }\end{array}$ & 12 & 58 & 1953JUL/SET & Flávio Motta \\
\hline arquitetura & sem autoria & "Paisagem brasileira” & $\begin{array}{c}\text { sobre a valorização da } \\
\text { arquitetura dos vilarejos no } \\
\text { interior do Brasil pelo cineasta } \\
\text { Alberto Cavalcanti }\end{array}$ & 12 & 62 & 1953JUL/SET & Flávio Motta \\
\hline fotografia & sem autoria & "Fotografias" ( ao ar livre) & $\begin{array}{l}\text { reprodução de fotografias de } \\
\text { Odorico Tavares }\end{array}$ & 12 & 64 & 1953JUL/SET & Flávio Motta \\
\hline
\end{tabular}


ÍNDICE CLASSIFICADO E COMENTADO

\begin{tabular}{|c|c|c|c|c|c|c|c|}
\hline TEMA & AUTOR & TÍTULO & DESCRIÇÃO & HABITAT & PÁG. & DATA & DESCRIÇÃO \\
\hline fotografia & A.S.L. & "Fotografias" ( no atelier) & $\begin{array}{l}\text { a fotografia como arte, não } \\
\text { apenas técnica }\end{array}$ & 12 & 66 & 1953JUL/SET & Flávio Motta \\
\hline arte & sem autoria & "Pintor de afrescos" & $\begin{array}{l}\text { o abandono da pintura sacra } \\
\text { pelos artistas modernos. Como } \\
\text { exceção Antonio Maria Nardi }\end{array}$ & 12 & 68 & 1953JUL/SET & Flávio Motta \\
\hline arte & sem autoria & "Del Prete" & $\begin{array}{c}\text { divulgação de exposição sediada } \\
\text { pelo MASP e comentários sobre } \\
\text { a trajetória do artista }\end{array}$ & 12 & 69 & 1953JUL/SET & Flávio Motta \\
\hline arte & sem autoria & “À Di Cavalcanti” & $\begin{array}{l}\text { um apelo de Habitat para o } \\
\text { início de um novo ciclo em sua } \\
\text { pintura - mais pensada, mais } \\
\text { controlada, mais coerente, } \\
\text { como o seu ciclo parisiense }\end{array}$ & 12 & 70 & 1953JUL/SET & Flávio Motta \\
\hline arte & sem autoria & "0 pintor Hauner" & $\begin{array}{c}\text { a promessa do artista } \\
\text { estrangeiro que aqui passou } \\
\text { a exercer papel de "Industrial } \\
\text { Design" }\end{array}$ & 12 & 72 & 1953JUL/SET & Flávio Motta \\
\hline arte & R. F. de Borba & "Pintor Pernambucano" & $\begin{array}{c}\text { Lula Cardoso Ayres e } \\
\text { a influencia do folclore } \\
\text { pernambucano, a temática } \\
\text { "fantasmagórica" e o trabalho } \\
\text { de ilustrador do livro de Gilberto } \\
\text { Freire sobre 0 Recife Antigo }\end{array}$ & 12 & 76 & 1953JUL/SET & Flávio Motta \\
\hline arte & sem autoria & "Folclore das artes plásticas" & $\begin{array}{c}\text { a influencia do folclore } \\
\text { pernambucano na produção } \\
\text { artística }\end{array}$ & 12 & 79 & 1953JUL/SET & Flávio Motta \\
\hline arte & sem autoria & "Baixaram portaria" & $\begin{array}{l}\text { indignação pela proibição em } \\
\text { São Paulo de pintar ou desenhar } \\
\text { em praças públicas. Imagens } \\
\text { de aulas ao ar livre do Museu } \\
\text { de Arte }\end{array}$ & 12 & 82 & 1953JUL/SET & Flávio Motta \\
\hline cinema & sem autoria & "0 Seminário do Museu" & $\begin{array}{l}\text { A iniciativa do Museu de } \\
\text { Arte em formar profissionia } \\
\text { aptos a trabalhar na indústria } \\
\text { cinematográfica brasileira. }\end{array}$ & 12 & 84 & 1953JUL/SET & Flávio Motta \\
\hline cinema & sem autoria & "0 Canto do Mar" & $\begin{array}{c}\text { divulgação do filme de Alberto } \\
\text { Cavalcanti que retrata o folclore } \\
\text { nordestino }\end{array}$ & 12 & 85 & 1953JUL/SET & Flávio Motta \\
\hline bailado & Alfonso Pinto & "0 conjunto folclórico" & $\begin{array}{c}\text { o sucesso da turnê do Conjunto } \\
\text { Folclórico Brasileiro pela } \\
\text { Espanha } \\
\end{array}$ & 12 & 85 & 1953JUL/SET & Flávio Motta \\
\hline música & sem autoria & "J. A. Franco" & $\begin{array}{c}\text { percurso profissional do músico } \\
\text { brilhante }\end{array}$ & 12 & 87 & 1953JUL/SET & Flávio Motta \\
\hline música & sem autoria & "Eleazar no Museu" & $\begin{array}{l}\text { o concerto realizado sob a } \\
\text { regência de Eleazar de Carvalho } \\
\text { na pinacoteca do Museu em } \\
\text { comemoração aos } 6 \text { anos do } \\
\text { início de suas atividades }\end{array}$ & 12 & 88 & 1953JUL/SET & Flávio Motta \\
\hline editorial & $\begin{array}{l}\text { German Bazin } \\
\text { (Conservador- } \\
\text { chefe do } \\
\text { Louvre) }\end{array}$ & $\begin{array}{l}\text { "Exposição do Museu de Arte de } \\
\text { São Paulo no L'Orangerie" }\end{array}$ & $\begin{array}{l}\text { texto transcrito do 'Arts' sobre o } \\
\text { sucesso da exposição do acervo } \\
\text { e do MASP no Museu l'Orangerie } \\
\text { em comemoração ao sétimo } \\
\text { ano de funcionamento do MASP }\end{array}$ & 13 & 1 & 19530UT/DEZ & Flávio Motta \\
\hline editorial & $\begin{array}{c}\text { Assis } \\
\text { Chateaubriand }\end{array}$ & $\begin{array}{l}\text { "0 valor intrínseco do que está } \\
\text { sendo apresentado em Paris" }\end{array}$ & $\begin{array}{c}\text { recusas ao convite de } \\
\text { Chateaubriand para conferir o } \\
\text { sucesso da exposição em Paris } \\
\text { e o descuido com as artes no } \\
\text { Brasil }\end{array}$ & 13 & 2 & 19530UT/DEZ & Flávio Motta \\
\hline arte & $\begin{array}{l}\text { Pietro Maria } \\
\text { Bardi }\end{array}$ & "Os quatro Nattier" & $\begin{array}{c}\text { a aquisiccão de quatro Nattier } \\
\text { pelo MASSP e o interesse e } \\
\text { reivindicação da França pelas } \\
\text { obras }\end{array}$ & 13 & 3 & 19530UT/DEZ & Flávio Motta \\
\hline arte & $\begin{array}{l}\text { Claire Gilles } \\
\text { Guilbert }\end{array}$ & $\begin{array}{l}\text { "Um milagre brasileiro } \\
\text { apaixonou Paris" }\end{array}$ & $\begin{array}{c}\text { a exposição no l'Orangerie como } \\
\text { demonstração da importância } \\
\text { do Brasil no campo das artes } \\
\text { e de Chateaubriand como } \\
\text { realizador }\end{array}$ & 13 & 4 & 19530UT/DEZ & Flávio Motta \\
\hline
\end{tabular}


ÍNDICE CLASSIFICADO E COMENTADO

\begin{tabular}{|c|c|c|c|c|c|c|c|}
\hline TEMA & AUTOR & TÍTULO & DESCRIÇÃO & HABITAT & PÁG. & DATA & DESCRIÇÃO \\
\hline arte & sem autoria & sem título & $\begin{array}{l}\text { resposta aos críticos de arte que } \\
\text { "desestimularam" a exposição } \\
\text { do acervo do MASP em Paris }\end{array}$ & 13 & 7 & 19530UT/DEZ & Flávio Motta \\
\hline $\begin{array}{l}\text { arquitetura - } \\
\text { projeto }\end{array}$ & Oswaldo Bratke & "Hospital Infantil no Morumbi" & $\begin{array}{l}\text { descreve a solução em um } \\
\text { bloco único que separa } \\
\text { as funções em duas alas } \\
\text { independentes (horizontal e } \\
\text { vertical), buscando a eficiência } \\
\text { dos fluxos }\end{array}$ & 13 & 8 & 19530UT/DEZ & Flávio Motta \\
\hline $\begin{array}{l}\text { arquitetura - } \\
\text { projeto }\end{array}$ & Rino Levi & "Instituto Central do Câncer" & $\begin{array}{l}\text { descreve minuciosamente a } \\
\text { solução da implantação, do } \\
\text { programa em três blocos, a } \\
\text { eficácia das circulações e do } \\
\text { sistema construtivo adotado }\end{array}$ & 13 & 10 & 19530UT/DEZ & Flávio Motta \\
\hline $\begin{array}{l}\text { arquitetura - } \\
\text { projeto }\end{array}$ & Eduardo Corona & "Colégio Estadual da Penha" & $\begin{array}{c}\text { do convênio escolar, breve } \\
\text { descrição do programa e da } \\
\text { solução adotada plasticamente e } \\
\text { funcionalmente }\end{array}$ & 13 & 19 & 19530UT/DEZ & Flávio Motta \\
\hline $\begin{array}{l}\text { arquitetura - } \\
\text { projeto }\end{array}$ & $\begin{array}{l}\text { Charles S. } \\
\text { Bosworth }\end{array}$ & $\begin{array}{l}\text { "Residência na Chácara } \\
\text { Tangará" }\end{array}$ & $\begin{array}{l}\text { residência de 3000m2 } \\
\text { desenvolvida por escritório } \\
\text { de Los Angeles, após estudo } \\
\text { realizado por arquitetos de } \\
\text { São Paulo, que optaram por } \\
\text { soluções bastantes distintas }\end{array}$ & 13 & 22 & 19530UT/DEZ & Flávio Motta \\
\hline $\begin{array}{l}\text { arquitetura - } \\
\text { projeto }\end{array}$ & $\begin{array}{l}\text { Antonio José } \\
\text { Capote Valente }\end{array}$ & "Edifício Normandia" & $\begin{array}{l}\text { descrição da solução em função } \\
\text { das premissas colocadas pelo } \\
\text { proprietário e pelo incorporador }\end{array}$ & 13 & 27 & 19530UT/DEZ & Flávio Motta \\
\hline $\begin{array}{l}\text { arquitetura - } \\
\text { projeto }\end{array}$ & $\begin{array}{l}\text { Vaidergorn e } \\
\text { Verona }\end{array}$ & “ Residência em São Paulo” & $\begin{array}{l}\text { importante integração entre } \\
\text { arquiteto e decoração - tom } \\
\text { publicitário }\end{array}$ & 13 & 28 & 19530UT/DEZ & Flávio Motta \\
\hline $\begin{array}{l}\text { arquitetura - } \\
\text { projeto }\end{array}$ & Flávio Motta & "0 antigo e o novo Itamarati" & $\begin{array}{l}\text { projeto de Henrique E. Mindlin } \\
\text { para ampliação do Ministério } \\
\text { das Relaçôes Exteriores - } \\
\text { enfrentamento entre moderno } \\
\text { e antigo }\end{array}$ & 13 & 31 & 19530UT/DEZ & Flávio Motta \\
\hline arquitetura & E. F. Brancante & "Nossa antiga São Paulo" & $\begin{array}{c}\text { texto que comenta o } \\
\text { crescimento e a transformação } \\
\text { urbana de São Paulo e } \\
\text { apresenta imagens do séc. } \\
\text { XIX encontradas na coleção de } \\
\text { Brancante } \\
\text { Brante }\end{array}$ & 13 & 35 & 19530UT/DEZ & Flávio Motta \\
\hline arquitetura & $\begin{array}{l}\text { Napoleão } \\
\text { Figueiredo }\end{array}$ & "A Fortaleza de Macapá" & $\begin{array}{l}\text { descrição do papel destas } \\
\text { construções na defesa do } \\
\text { território nacional, análise ao } \\
\text { forte construído no séc XVIII }\end{array}$ & 13 & 43 & 19530UT/DEZ & Flávio Motta \\
\hline $\begin{array}{l}\text { arquitetura - } \\
\text { projeto }\end{array}$ & $\begin{array}{l}\text { Wit-Olaf } \\
\text { Prochnik }\end{array}$ & "Projeto para favelas" & $\begin{array}{c}\text { projeto de final do curso. } \\
\text { Busca atender o problema da } \\
\text { ocupação dos morros, através } \\
\text { de unidades de moradia mínima } \\
\text { construída em mutirão à partir } \\
\text { de elementos pré-fabricados }\end{array}$ & 13 & 49 & 19530UT/DEZ & Flávio Motta \\
\hline arquitetura & sem autoria & $\begin{array}{c}\text { "Arquitetura e arquitetura de } \\
\text { jardins" }\end{array}$ & $\begin{array}{l}\text { a importância da relação entre } \\
\text { arquitetura e os jardins e o } \\
\text { convite através do Museu de } \\
\text { Burle Marx expor sua obra nos } \\
\text { Estados Unidos }\end{array}$ & 13 & 52 & 19530UT/DEZ & Flávio Motta \\
\hline arquitetura & sem autoria & "Calçadas: Alice Brill” & $\begin{array}{l}\text { fotografias de diversos padrões } \\
\text { de calçadas em mosaico } \\
\text { romano }\end{array}$ & 13 & 55 & 19530UT/DEZ & Flávio Motta \\
\hline poesia & sem autoria & "0 poeta Alberto de Oliveira" & publicação da poesia Fontes & 13 & 56 & 19530UT/DEZ & Flávio Motta \\
\hline artesanato & sem autoria & $\begin{array}{l}\text { "Pintores de ruas: Jacinto S. de } \\
\text { Mello Alves" }\end{array}$ & $\begin{array}{l}\text { o reconhecimento de pintores } \\
\text { como Jacinto. Publicação de } \\
\text { fotografias de Sascha Harnisch } \\
\text { documentando a obra. }\end{array}$ & 13 & 57 & 19530UT/DEZ & Flávio Motta \\
\hline museus & Guido Fonzaro & "A cultura figurativa da Infância" & $\begin{array}{l}\text { as particularidades da educação } \\
\text { artísticas para as crianças e } \\
\text { os projetos do Museu para } \\
\text { "revolucionar" esse campo }\end{array}$ & 13 & 60 & 19530UT/DEZ & Flávio Motta \\
\hline
\end{tabular}


ÍNDICE CLASSIFICADO E COMENTADO

\begin{tabular}{|c|c|c|c|c|c|c|c|}
\hline TEMA & AUTOR & TÍTULO & DESCRIÇÃO & HABITAT & PÁG. & DATA & DESCRIÇÃO \\
\hline propaganda & sem autoria & "Bramante Buffoni" & $\begin{array}{c}\text { a características do artista } \\
\text { completo vindo de Milão e que } \\
\text { no Museu de Arte programou } 0 \\
\text { curso de artes gráficas. } \\
\end{array}$ & 13 & 65 & 19530UT/DEZ & Flávio Motta \\
\hline fotografia & sem autoria & "Paisagens" & $\begin{array}{l}\text { imagens de uma cidade no } \\
\text { interior de Pernambuco }\end{array}$ & 13 & 66 & 19530UT/DEZ & Flávio Motta \\
\hline arte & Flávio Motta & "Gravuras: David Perlow" & $\begin{array}{l}\text { divulgação da obra do artista } \\
\text {-litografias e xilografias }\end{array}$ & 13 & 67 & 19530UT/DEZ & Flávio Motta \\
\hline arte & Flávio Motta & "Afrescos: Pennacchi" & $\begin{array}{c}\text { imagens dos afrescos da Igreja } \\
\text { de N. S. da Paz, em São Paulo. } \\
\text { A simplificação da decoração } \\
\text { e da arquitetura em um templo } \\
\text { religioso }\end{array}$ & 13 & 68 & 19530UT/DEZ & Flávio Motta \\
\hline arte & Flávio Motta & "Pintor solitário: Mercier" & $\begin{array}{c}\text { artista expressionista que } \\
\text { trabalha em temas religiosos } \\
\text { na cidade de Barbacena. } \\
\text { Documentação por fotografias } \\
\text { de Lise Modern }\end{array}$ & 13 & 70 & 19530UT/DEZ & Flávio Motta \\
\hline arte & Flávio Motta & "Gravuras: Giselda" & $\begin{array}{c}\text { divulgação da obra da jovem } \\
\text { Giselda Klinger, com forte } \\
\text { influencia de Lasar Segall - } \\
\text { litografias }\end{array}$ & 13 & 72 & 19530UT/DEZ & Flávio Motta \\
\hline arte & Flávio Motta & Inéditos de Brecheret" & $\begin{array}{c}\text { duas peças e Brecheret } \\
\text { encontradas em um Museu } \\
\text { Francês }\end{array}$ & 13 & 74 & 19530UT/DEZ & Flávio Motta \\
\hline arte & Flávio Motta & "Escultura: Karl Hansen” & $\begin{array}{l}\text { divulgação do trabalho sobre } \\
\text { madeira do artista hamburguês }\end{array}$ & 13 & 75 & 19530UT/DEZ & Flávio Motta \\
\hline arte & Flávio Motta & "Escultura nova" & $\begin{array}{c}\text { divulgação da obra da escultora } \\
\text { Italiana que teve a obra exposta } \\
\text { no Museu }\end{array}$ & 13 & 76 & 19530UT/DEZ & Flávio Motta \\
\hline arte & Flávio Motta & "Zélia Salgado" & $\begin{array}{c}\text { exposição da obra da artista } \\
\text { no Museu de Arte e a } \\
\text { recomendação de Habitat para } \\
\text { que assuma em sua obra uma } \\
\text { postura profissional }\end{array}$ & 13 & 77 & 19530UT/DEZ & Flávio Motta \\
\hline museus & Flávio Motta & "0 Museu num álbum” & $\begin{array}{l}\text { lançamento do livro editado pela } \\
\text { Livraria Kosmos, com fotografia } \\
\text { de Peter Scheier e paginação de } \\
\text { Jorge Rado, que documenta } 0 \\
\text { desenvolvimento de São Paulo }\end{array}$ & 13 & 78 & 19530UT/DEZ & Flávio Motta \\
\hline arte & $\begin{array}{l}\text { Gertrudes } \\
\text { Rosenthal }\end{array}$ & "400 anos de arte moderna" & $\begin{array}{c}\text { texto publicado no ‘News', } \\
\text { escrito pela diretora da Walters } \\
\text { Art Gallery,cujo mote é o } \\
\text { mesmo da exposição de mesmo } \\
\text { tema: a relação entre a arte } \\
\text { antiga e a moderna }\end{array}$ & 13 & 80 & 19530UT/DEZ & Flávio Motta \\
\hline arte & Enrico Schaeffer & "Discussões" & $\begin{array}{l}\text { visão sobre a arte moderna do } \\
\text { antigo professor da Universidade } \\
\text { Católica de São Paulo - uma } \\
\text { arte que retrata uma época } \\
\text { individual, etc }\end{array}$ & 13 & 82 & 19530UT/DEZ & Flávio Motta \\
\hline arte & G. Novelli & "A nova plástica" & $\begin{array}{c}\text { sobre a missão da arte } \\
\text { abstrata, que chama de } \\
\text { "novo objetivismo", suprir as } \\
\text { exigências estéticas e sociais do } \\
\text { nosso tempo }\end{array}$ & 13 & 84 & 19530UT/DEZ & Flávio Motta \\
\hline cinema & $\begin{array}{l}\text { Florentino } \\
\text { Barbosa e Silva }\end{array}$ & $\begin{array}{c}\text { "Festival de Cinema de São } \\
\text { Paulo" }\end{array}$ & $\begin{array}{c}\text { critica à comissão organizadora } \\
\text { que não filiou o Brasil a } \\
\text { Federação Internacional das } \\
\text { Associações de Produtores de } \\
\text { Filmes, o que dificulta o acesso } \\
\text { a produção internacional }\end{array}$ & 13 & 85 & 19530UT/DEZ & Flávio Motta \\
\hline cinema & $\begin{array}{c}\text { Florentino } \\
\text { Barbosa e Silva }\end{array}$ & "0 sertanejo: Lima Barreto" & $\begin{array}{l}\text { entrevista com o diretor acerca } \\
\text { do filme ainda não estreitado }\end{array}$ & 13 & 86 & 19530UT/DEZ & Flávio Motta \\
\hline teatro & & "Pirandello no T.B.C." & $\begin{array}{c}\text { Sobre o sucesso de critica a } \\
\text { peça "Assim é (se lhe parece)" }\end{array}$ & 13 & 87 & 19530UT/DEZ & Flávio Motta \\
\hline
\end{tabular}


ÍNDICE CLASSIFICADO E COMENTADO

\begin{tabular}{|c|c|c|c|c|c|c|c|}
\hline TEMA & AUTOR & TÍTULO & DESCRIÇÃO & HABITAT & PÁG. & DATA & DESCRIÇÃO \\
\hline bailado & & "O Ballet da Juventude" & $\begin{array}{l}\text { método utilizado pelo diretor } \\
\text { Dimitri, vindo de N.Y. pela } \\
\text { "Dance Notation Bureau" }\end{array}$ & 13 & 87 & 19530UT/DEZ & Flávio Motta \\
\hline editorial & Lina Bo Bardi & & $\begin{array}{c}\text { findo o período de incertezas, } \\
\text { o início de uma nova fase } \\
\text { da revista marcada pela } \\
\text { bimensalidade e por um balanço }\end{array}$ & 14 & 1 & 1954JAN/FEV & Lina Bo Bardi \\
\hline cultura & $\begin{array}{c}\text { Assis } \\
\text { Chateaubriand }\end{array}$ & "0 índio e o homem do planalto" & $\begin{array}{c}\text { chama a atenção para o papel } \\
\text { do índio na constituição dos } \\
\text { costumes e da população } \\
\text { brasileira e conclama sua } \\
\text { valorização. }\end{array}$ & 14 & 2 & 1954JAN/FEV & Lina Bo Bardi \\
\hline $\begin{array}{l}\text { arquitetura - } \\
\text { projeto }\end{array}$ & $\begin{array}{l}\text { Lina Bo e P. L. } \\
\text { Nervi }\end{array}$ & "Taba Guaianases" & $\begin{array}{c}\text { projetado para sediar a rádio } \\
\text { e televisão dos "Diários } \\
\text { Associados", um auditório } \\
\text { para } 5000 \text { lugares e dois } \\
\text { teatros de } 1500 \text {, além de } 1500 \\
\text { apartamentos. 0 texto evidencia } \\
\text { a 'autonomia' do conjunto e a } \\
\text { standartização das unidades }\end{array}$ & 14 & 4 & 1954JAN/FEV & Lina Bo Bardi \\
\hline $\begin{array}{l}\text { arquitetura - } \\
\text { projeto }\end{array}$ & Geraldo Ferraz & $\begin{array}{l}\text { "Urbanização na praia de } \\
\text { Pernambuco" }\end{array}$ & $\begin{array}{l}\text { apresentação elogiosa ao } \\
\text { projeto de Henrique E. Mindlin, } \\
\text { como exemplo de ocupação no } \\
\text { litoral. Ilustrações detalhadas } \\
\text { das tipologias e do projeto geral }\end{array}$ & 14 & 11 & 1954JAN/FEV & Lina Bo Bardi \\
\hline arquitetura & $\begin{array}{l}\text { Abelardo de } \\
\text { Souza }\end{array}$ & $\begin{array}{l}\text { "IV Congresso Brasileiro de } \\
\text { Arquitetos" }\end{array}$ & $\begin{array}{l}\text { balanço critico de Abelardo } \\
\text { de Souza ao Congresso, } \\
\text { onde coloca a ausência de } \\
\text { discussões como planejamento } \\
\text { urbano, déficit habitacional, } \\
\text { regulamentação municipal, etc. }\end{array}$ & 14 & 23 & 1954JAN/FEV & Lina Bo Bardi \\
\hline $\begin{array}{l}\text { arquitetura - } \\
\text { documento }\end{array}$ & $\begin{array}{l}\text { Walter Gropius e } \\
\text { Alvar Aalto }\end{array}$ & "Duas Conferências" & $\begin{array}{l}\text { transcrição da conferência } \\
\text { realizada pelos arquitetos } \\
\text { Gropius e Aalto por ocasião da } \\
\text { vinda à São Paulo }\end{array}$ & 14 & 25 & 1954JAN/FEV & Lina Bo Bardi \\
\hline $\begin{array}{l}\text { arquitetura - } \\
\text { documento }\end{array}$ & Max Bill & $\begin{array}{l}\text { "0 arquiteto, a arquitetura, a } \\
\text { sociedade" }\end{array}$ & $\begin{array}{c}\text { transcrição da conferência } \\
\text { realizada na FAU-USP em junho } \\
\text { de } 1953\end{array}$ & 14 & & 1954JAN/FEV & Lina Bo Bardi \\
\hline arquitetura & $\begin{array}{l}\text { atribuído a Lina } \\
\text { Bo Bardi }\end{array}$ & $\begin{array}{l}\text { "Denúncia" - "Casas, eles } \\
\text { também precisam" }\end{array}$ & $\begin{array}{l}\text { a questão do déficit habitacional } \\
\text { como responsabilidade social }\end{array}$ & 14 & 28 & 1954JAN/FEV & Lina Bo Bardi \\
\hline arte & Lina Bo Bardi & "A II Bienal" & $\begin{array}{l}\text { crítica ao descuido na } \\
\text { organização da exposição com } \\
\text { o fim pedagógico para } 0 \text { grande } \\
\text { público }\end{array}$ & 14 & 29 & 1954JAN/FEV & Lina Bo Bardi \\
\hline teatro & Gianni Ratto & "Reflexões sobre cenografia" & $\begin{array}{l}\text { a transformação da cenografia } \\
\text { ao longo dos tempos }\end{array}$ & 14 & 40 & 1954JAN/FEV & Lina Bo Bardi \\
\hline arte & & $\begin{array}{l}\text { "Paisagem brasileira: um } \\
\text { primitivo" }\end{array}$ & $\begin{array}{l}\text { pintura primitiva baiana do séc. } \\
\text { XVIII, quadro exposto na II Bienal }\end{array}$ & 14 & 45 & 1954JAN/FEV & Lina Bo Bardi \\
\hline arte & & "Imagens brasileiras" & $\begin{array}{l}\text { sobre a coleção de Stanislau } \\
\text { Herstal de imagens de santos } \\
\text { domésticos, mas espontâneos } \\
\text { que as imagens existentes nas } \\
\text { igrejas }\end{array}$ & 14 & 46 & 1954JAN/FEV & Lina Bo Bardi \\
\hline museus & $\begin{array}{l}\text { J. F. de Almeida } \\
\text { Prado }\end{array}$ & $\begin{array}{c}\text { "Grandeza e vicissitude do } \\
\text { Museu de Arte" }\end{array}$ & $\begin{array}{l}\text { a importância da iniciativa de } \\
\text { Chateaubriand e da direção de } \\
\text { Bardi no sucesso do Museu no } \\
\text { exterior e a necessidade de uma } \\
\text { nova sede, a ausência de apoio } \\
\text { da administração pública }\end{array}$ & 14 & 48 & 1954JAN/FEV & Lina Bo Bardi \\
\hline museus & & "O Museu de Arte de São Paulo" & $\begin{array}{l}\text { da exposição das obras do } \\
\text { Museu em Bruxelas, no Palais } \\
\text { des Beaux Arts, e em seguida } \\
\text { será Utrecht, Berna e Londres }\end{array}$ & 14 & 49 & 1954JAN/FEV & Lina Bo Bardi \\
\hline museus & & "Um museu brasileiro" & $\begin{array}{l}\text { trás a repercussão impressa em } \\
\text { diversos jornais franceses das } \\
\text { atividades e cursos do Museu }\end{array}$ & 14 & 50 & 1954JAN/FEV & Lina Bo Bardi \\
\hline
\end{tabular}


ÍNDICE CLASSIFICADO E COMENTADO

\begin{tabular}{|c|c|c|c|c|c|c|c|}
\hline TEMA & AUTOR & TÍTULO & DESCRIÇÃO & HABITAT & PÁG. & DATA & DESCRIÇÃO \\
\hline museus & & $\begin{array}{l}\text { "Uma opinião de Lionello Venturi } \\
\text { sobre o Museu de Arte de São } \\
\text { Paulo" }\end{array}$ & $\begin{array}{c}\text { ensaio sobre o Museu publicado } \\
\text { em "La Stampa", descreve } \\
\text { sua história, a surpresa dos } \\
\text { franceses e chama a atenção } \\
\text { sob o ponto de vista educativo e } \\
\text { museográfico }\end{array}$ & 14 & 51 & 1954JAN/FEV & Lina Bo Bardi \\
\hline museus & & “Introdução ao Museu de Arte" & $\begin{array}{l}\text { trata da transcrição das cinco } \\
\text { páginas dedicadas ao Museu de } \\
\text { Arte na Revista Domus de junho } \\
\text { deste mesmo ano. }\end{array}$ & 14 & 52 & 1954JAN/FEV & Lina Bo Bardi \\
\hline fotografia & & $\begin{array}{l}\text { "Fotografias de Marcel } \\
\text { Gautherot" }\end{array}$ & $\begin{array}{l}\text { descreve o percurso profissional } \\
\text { do fotógrafo oficial da Diretoria } \\
\text { do Patrimônio Histórico e } \\
\text { publica imagens suas. }\end{array}$ & 14 & 54 & 1954JAN/FEV & Lina Bo Bardi \\
\hline crônicas & Alencastro & "Crônicas" & & 14 & 56 & 1954JAN/FEV & Lina Bo Bardi \\
\hline arquitetura & Lina Bo Bardi & "A Catedral" & crítica a catedral de São Paulo & 14 & 59 & 1954JAN/FEV & Lina Bo Bardi \\
\hline crônicas & Alencastro & "Crônicas e fim do texto" & & 14 & 61 & 1954JAN/FEV & Lina Bo Bardi \\
\hline arte & & $\begin{array}{c}\text { "Exposição de Victor Brecheret } \\
\text { na Galeria Tenreiro" }\end{array}$ & divulgação da exposição & 14 & 67 & 1954JAN/FEV & Lina Bo Bardi \\
\hline arte & & "Ceramista Lilly R. Montagne" & $\begin{array}{l}\text { divulgação da exposição a } \\
\text { realizar-se na Livraria Francesa }\end{array}$ & 14 & 67 & 1954JAN/FEV & Lina Bo Bardi \\
\hline arte & $\begin{array}{l}\text { Wolfgang } \\
\text { Pfeiffer }\end{array}$ & $\begin{array}{c}\text { "Desenhos de Lisa Ficker- } \\
\text { Hofmann" }\end{array}$ & $\begin{array}{c}\text { sobre a obra da artista e as } \\
\text { fases que marcam sua produção }\end{array}$ & 14 & 68 & 1954JAN/FEV & Lina Bo Bardi \\
\hline arte & $\begin{array}{l}\text { Wolfgang } \\
\text { Pfeiffer }\end{array}$ & "Felícia Leirner" & $\begin{array}{c}\text { obra aceita para expor na Bienal } \\
\text { - aluna de Brecheret }\end{array}$ & 14 & 69 & 1954JAN/FEV & Lina Bo Bardi \\
\hline publicitário & & $\begin{array}{l}\text { "Revolução no campo técnico } \\
\text { da moagem de trigo" }\end{array}$ & $\begin{array}{c}\text { obra das Construtora Mauá } \\
\text { Ltda. para o Moinho Selmi-Dei, } \\
\text { em Santo André } \\
\end{array}$ & 14 & 70 & 1954JAN/FEV & Lina Bo Bardi \\
\hline publicitário & & $\begin{array}{l}\text { "Edifício comercial e residencial } \\
\text { em São Paulo" }\end{array}$ & $\begin{array}{l}\text { projeto do Eng. Arq. Miguel } \\
\text { Badra Junior, entre a R. } \\
\text { Bernardino de Campos e a Rua } \\
\text { Paraíso (desenhos técnicos) }\end{array}$ & 14 & 72 & 1954JAN/FEV & Lina Bo Bardi \\
\hline publicitário & & $\begin{array}{c}\text { "Edifício de apartamentos em } \\
\text { Guarujá" }\end{array}$ & $\begin{array}{l}\text { quatro edifícios no Guarujá } \\
\text { Construtora Richter e Lotufo S. } \\
\text { A. e arquitetos Otávio Lotufo e } \\
\text { Jorge L. Richter }\end{array}$ & 14 & 75 & 1954JAN/FEV & Lina Bo Bardi \\
\hline publicitário & & $\begin{array}{l}\text { "ARQUITETURA-sintese de todas } \\
\text { as artes" }\end{array}$ & $\begin{array}{l}\text { obras e realizações da Firma J. } \\
\text { Artacho Jurado, Soc. Técnica } \\
\text { Ltda. (Louvre, Viadutos, } \\
\text { Acácias, Verde Mar, D. Veridiana } \\
\text { Prado, Saint-Honoré, Bretagne, } \\
\text { Hortênsias) }\end{array}$ & 14 & 76 & 1954JAN/FEV & Lina Bo Bardi \\
\hline editorial & $\begin{array}{l}\text { Lina Bo Bardi, } \\
\text { Pietro Maria } \\
\text { Bardi e Rodolfo } \\
\text { Klein }\end{array}$ & “Declaração” & $\begin{array}{l}\text { Pedido de demissão de Lina } \\
\text { Bo e P. M. Bardi ao fim de um } \\
\text { caminho percorrido e o aceite de } \\
\text { R. Klein com agradecimentos ao } \\
\text { casal e ao Museu de Arte e as } \\
\text { novas perspectivas de Habitat }\end{array}$ & 15 & 1 & 1954MAR/ABR & Lina Bo Bardi \\
\hline arquitetura & $\begin{array}{c}\text { Jorge M, } \\
\text { Moreira }\end{array}$ & $\begin{array}{l}\text { "Cidade Universitária no Rio de } \\
\text { Janeiro" }\end{array}$ & $\begin{array}{c}\text { discorre sobre o conceito de } \\
\text { Campus Universitário }\end{array}$ & 15 & 2 & 1954MAR/ABR & Lina Bo Bardi \\
\hline arquitetura & sem autoria & "Universitas" & $\begin{array}{c}\text { apresenta um histórico das } \\
\text { Universidades ao longo dos } \\
\text { séculos } \\
\end{array}$ & 15 & A & 1954MAR/ABR & Lina Bo Bardi \\
\hline $\begin{array}{l}\text { arquitetura - } \\
\text { projeto }\end{array}$ & $\begin{array}{l}\text { Luiz H. De B. } \\
\text { Horta Barbosa }\end{array}$ & "Índices Universitários" & $\begin{array}{l}\text { análise de índices comparativos, } \\
\text { relativos a educação. Segue } \\
\text { fotografias da obra e projeto }\end{array}$ & 15 & 3 & 1954MAR/ABR & Lina Bo Bardi \\
\hline arquitetura & Franco Albini & $\begin{array}{c}\text { "Arquitetura dos Museus e } \\
\text { os Museus na Urbanística } \\
\text { Moderna" }\end{array}$ & $\begin{array}{l}\text { publicação da conferência } \\
\text { realizada por Franco Albini, } \\
\text { no congresso do "Icom" em } \\
\text { Gênova onde foi discutidos } \\
\text { questões relativas aos museus. }\end{array}$ & 15 & 29 & 1954MAR/ABR & Lina Bo Bardi \\
\hline arquitetura & $\begin{array}{l}\text { Pietro Maria } \\
\text { Bardi }\end{array}$ & "Auguste Perret (1874-1954)" & $\begin{array}{l}\text { homenagem póstuma ao } \\
\text { arquiteto que incorporou } 0 \\
\text { concreto à arquitetura como } \\
\text { estrutura, despindo-0 de } \\
\text { qualquer revestimento }\end{array}$ & 15 & 32 & 1954MAR/ABR & Lina Bo Bardi \\
\hline
\end{tabular}


ÍNDICE CLASSIFICADO E COMENTADO

\begin{tabular}{|c|c|c|c|c|c|c|c|}
\hline TEMA & AUTOR & TÍTULO & DESCRIÇÃO & HABITAT & PÁG. & DATA & DESCRIÇÃO \\
\hline arquitetura & $\begin{array}{l}\text { Pietro Maria } \\
\text { Bardi }\end{array}$ & $\begin{array}{c}\text { "0 arquiteto de Jardins, Roberto } \\
\text { Burle Marx" }\end{array}$ & $\begin{array}{l}\text { reprodução do prefácio do } \\
\text { catálogo da exposição de Burle } \\
\text { Marx, através do MASP, no } \\
\text { Smithisonian Institution. }\end{array}$ & 15 & 36 & 1954MAR/ABR & Lina Bo Bardi \\
\hline arquitetura & $\begin{array}{l}\text { Pietro Maria } \\
\text { Bardi }\end{array}$ & "Esculturas para jardins" & $\begin{array}{c}\text { fotografias de esculturas para } \\
\text { jardins de autoria de Burle Marx }\end{array}$ & 15 & 39 & 1954MAR/ABR & Lina Bo Bardi \\
\hline arte & $\begin{array}{l}\text { Napoleão } \\
\text { Figueiredo }\end{array}$ & "Arte Amazônica" & $\begin{array}{l}\text { alerta para a importância do } \\
\text { estudo e conservação da } \\
\text { arte indígena (neste caso a } \\
\text { amazônica) } \\
\end{array}$ & 15 & 41 & 1954MAR/ABR & Lina Bo Bardi \\
\hline arte & $\begin{array}{l}\text { Pietro Maria } \\
\text { Bardi }\end{array}$ & "Aonde vai a Pintura?" & $\begin{array}{c}\text { questiona o significado da } \\
\text { "enxurrada" de arte abstrata que } \\
\text { encontrou na Europa e o seu } \\
\text { destino }\end{array}$ & 15 & 45 & 1954MAR/ABR & Lina Bo Bardi \\
\hline museus & & "0 Museu de Arte em Utrecht" & $\begin{array}{c}\text { informativo sobre o percurso } \\
\text { das exposição das obras do } \\
\text { MASP na Europa }\end{array}$ & 15 & 51 & 1954MAR/ABR & Lina Bo Bardi \\
\hline $\begin{array}{l}\text { desenho } \\
\text { industrial }\end{array}$ & & "Trabalho Domestico" & $\begin{array}{l}\text { duas correspondências } \\
\text { relativas aos acontecimentos } \\
\text { relativos a casa: "0 Salon de } \\
\text { Arts Ménagers" e a exposição } \\
\text { "Téchniques de 1954" }\end{array}$ & 15 & 52 & 1954MAR/ABR & Lina Bo Bardi \\
\hline \multirow[t]{6}{*}{ fotografia } & & "Visor sobre o Rio" & $\begin{array}{c}\text { fotografias de Sascha Harnisch } \\
\text { documentando cenas cotidians } \\
\text { do Rio de Janeiro }\end{array}$ & 15 & 54 & 1954MAR/ABR & Lina Bo Bardi \\
\hline & $\begin{array}{l}\text { Pietro Maria } \\
\text { Bardi }\end{array}$ & "0 Homem Anti- Natureza?" & $\begin{array}{c}\text { sobre a indiferença da } \\
\text { imprensa diante de importantes } \\
\text { Congressos Internacional de } \\
\text { proteção da natureza (Caracas } \\
\text { e Manila), }\end{array}$ & 15 & 56 & 1954MAR/ABR & Lina Bo Bardi \\
\hline & Alencastro & "Crônicas" & & 15 & 60 & 1954MAR/ABR & Lina Bo Bardi \\
\hline & & "The big Carnival" & & 15 & $\mathrm{C}$ & 1954MAR/ABR & Lina Bo Bardi \\
\hline & & "Teatro" & & 15 & D & 1954MAR/ABR & Lina Bo Bardi \\
\hline & Alencastro & "Crônicas e fim do texto" & & 15 & 64 & 1954MAR/ABR & Lina Bo Bardi \\
\hline
\end{tabular}


Conversa com o Prof. Flávio Motta

São Paulo, 27 de abril de 2006. Local: Rua Bartira - residência do Profs.

A conversa teve início por telefone, na segunda tentativa de agendar uma conversa.

Ao saber qual era o meu interesse - a pesquisa sobre a revista Habitat, demonstrou-se surpreso: Como você a descobriu?; Como sabe qual foi minha participação?

E demonstrou desconhecer a existência de exemplares da publicação nas bibliotecas da FAU-USP e na EESCUSP.

Disse, como quem se furta, ser muito jovem quando participou da revista e agora muito velho...

Mas, enfim convidou-me para ir até sua casa naquela tarde: Pra mim só existe o presente. E não traga gravador, ouviu.

A conversa se deu na copa de sua casa. Uma sala de pequenas dimensões, mas com paredes repletas de quadros. Pediu-me para sentar a sua frente e falar um pouco sobre a pesquisa. A parti daí Flávio Motta deu início a uma aula de história: a formação da cidade de São Paulo, sua importância insignificante durante 0 período do Império. 0 Rio de Janeiro com a corte e 0 aparato necessário para D. João VI permanecer no Brasil, a Biblioteca Municipal, o Teatro Municipal, as reformas urbanas e uma sociedade formada maciçamente por europeus "vindos" da Europa. Em oposição, a cidade de São Paulo, um entreposto entre o litoral e 0 interior do país, uma vila com características caipiras, uma roça de sertão. Motta chama a atenção para a transformação de São Paulo com a implantação a Faculdade de Direito em 1828, quase simultânea a Faculdade de Direito do Rio de Janeiro, e com ela a formação de uma intelectualidade fortemente pautada pela literatura. A importância da Igreja e seu papel educador para a construção da sociedade paulistana. A cidade organizada a partir de seus Largos: São Bento, São Francisco, etc. 0 desenvolvimento econômico com 0 cultivo do café e a presença maciça da imigração, principalmente a italiana, que marcou o crescimento da cidade e dobrou sua população na virada do século, atingindo cerca de 240 mil habitantes.

A formação artística que no Rio de Janeiro era "dirigida” pela Escola Nacional de Belas Artes e suas premiações que levavam muitos estudantes à Europa para ter aula com grandes mestres; em São Paulo girava em torno de uma organização de artistas, a Associação dos Artistas, a qual realizava exposições com mostras independentes. Flávio Motta descreveu sua participação nesta Associação e a forma como conseguiam algum espaço nos jornais da época: "mendigávamos por uma nota nos jornais. Uma nota onde havia sempre a imagem com uma pequena legenda de uma das obras a ser exposta na sede". Assim retrata a dificuldade de 
ser artista nesse momento e a precariedade das condições.

Na Europa chama a atenção para a destruição da sociedade que marcou o fim da ll Guerra, como as dificuldades levam os indivíduos a uma sobrevivência mesquinha, onde o outro, o sentido de nação, desaparecem. Desta forma, inscreve a viajem do casal Bardi ao Brasil: trazer tudo - obras de arte, objetos de valor, tudo que fosse necessário para uma nova vida, num país onde era possível viver e realizar projetos.

Nesse ponto destaca a amizade do casal com o crítico brasileiro Mario da Silva Brito na Itália e as facilidades e informações que deste poderiam ter obtido. Descreve, citando o livro de Fernando Moraes ${ }^{1}$, a exposição organizada por Bardi no saguão do Ministério de Educação e Saúde, no Rio de Janeiro e o encontro entre Bardi e Assis Chateaubriand, provavelmente provocado por Frederico Barata. Chama a atenção para o interesse de Chatô pelas artes e o retrata como um homem de grandes qualidades e grandes defeitos. Mas de maneira nenhuma um homem medíocre.

Quando já ia dar início as atividades no Masp na Rua 7 de abril, o interrompi perguntando como tinha ingressado no Masp. Disse: Esta é uma história bonita!

Contou que seu pai desenhava muito bem e que sabia valorizar a arte. Descreveu as relações que mantinha com Flávio de Carvalho, Nelson Nóbrega e especialmente com Quirino da Silva, então crítico de arte dos Diários Associados e de quem era muito amigo e cujo ateliê possuía uma vasta biblioteca a qual costumava freqüentar. E foi ali, neste ateliê que conheceu Bardi e Lina. Contou já ter conhecimento de que o Masp ia ser instalado em São Paulo - comentou a dúvida entre a capital e a cidade do café - e que ali, naquele ateliê, estavam guardadas algumas obras que seriam do Masp. Descreveu o dia do encontro: Bardi viu seus desenhos para os cartazes estilo realismo socialismo que havia feito para as Ferrovias - uma campanha contra o desperdício e pela segurança, encomendado por seu pai e que nunca foi veiculada (descreveu os desenhos com detalhes); e nesta ocasião Quirino pediu a Flávio que auxiliasse o casal de mudança para São Paulo e que encontrava algumas dificuldades. Assim deu-se inicio a uma relação que se entendeu até o final da vida de Bardi.

Nesta época havia acabado de se formar pela Faculdade de Filosofia em Pedagogia e planejava casar e ir trabalhar em Batatais (?) em uma instituição de ensino - descreveu brevemente sua formação: família proprietária de terras no interior de São Paulo, na região de Capivari (?). 0 período que passou durante quatro anos de sua infância dentro de uma instituição de reabilitação para menores que, apesar de filho do diretor, 
Ihe deixou muitas marcas. A decisão de ser artista e a dificuldade do pai de aceitar sua escolha - no entanto Quirino disse que não, que em três meses seria inaugurado o Masp e que lá teria um lugar para ele. Assim foi. Chamado por Bardi no prédio dos Diários Associados - numa saleta, aquela onde fica o mestre de obras e os arquitetos e engenheiros vão quando tem que discutir projeto - onde havia instalado um escritório, realizou uma "entrevista" que confirmou seu posto no Museu.

Descreveu as dificuldades para a formação do Masp, a sede que ocupava dois andares do prédio em construção dos Diários Associados, as madrugadas passadas em claro, a noite que dormiu sobre as cortinas de uma exposição que montavam, etc.

Flavio diz imaginar a revista ser um projeto de Bardi e Lina, um anseio em continuar aqui a atividades editoriais que vinham desempenhando na Europa. Destaca entre as diversas atividades ligadas ao mercado editorial, atividades jornalísticas de Bardi no Corriere della Sera e de Lina na revista Domus. E é a essa afinidade de envolvimento e experiência com publicações, somada a "ingenuidade" de Bardi em acreditar que faria aqui a primeira revista modernista do Brasil, que Motta credita o nascimento da revista Habitat.

Como resposta a uma afirmação que eu havia feito, ainda durante a conversa ao telefone, falou das revistas de literatura e arte que havia antes deste período. Sobre a iniciativa do Pirralho e de RASM ${ }^{2}$, uma revista de Flávio de Carvalho que contava com a participação de muitos modernos, como Calder, etc. Tudo para indicar a necessidade de olhar em "águas profundas" e perceber que, embora Bardi achasse que com Habitat iria inaugurar aqui uma atividade editorial que já desempenhada na Europa, isso era uma "ilusão" quase infantil.

Ao caracterizar Lina, Motta cantarolou uma melodia e disse: É uma música popular. Ela viu estas pessoas. Ela percebeu estas pessoas que ninguém tinha percebido. Para confirmar a canção: “(...) são casas simples com cadeiras na calçada, e na fachada escrito em cima que é um lar (ele começou a me acompanhar). Pela varanda flores tristes e baldias, como a alegria que não tem onde encostar (...) É gente humilde, que vontade de chorar. ${ }^{3}$

Motta falou com muito carinho e admiração do casal Bardi. Descreveu a ocasião em que, ao deixar o hospital em conseqüência de uma doença que havia adquirido no norte, Lina pediu que fosse até o Morumbi para ver Bardi que estava muito "caído". Disse que os encontrou bem velhinhos e que quando contou a Lina que ele acabava de sair do hospital, ela o olhou com aquela cara que ela fazia e disse: Flávio, isso não se faz! 
Relatou também o episódio que diz ter marcado sua relação com Lina e que envolve diretamente a revista: pela ocasião da viajem de Bardi à Europa, acompanhando o acervo da pinacoteca do MASP em exposição em instituições européias, Motta acompanhou o casal até 0 aeroporto e relatou que 0 italiano estava muito chateado com o que estava acontecendo (disse que não cabia ali relatar tais fatos) e durante o percurso sugeriu que deveriam acabar com Habitat. Motta argumentou que era necessário continuar, que tinha um compromisso com 0 editor - Rodolfo Klein - e que este tinha um compromisso com os anunciantes e que também havia material suficiente para mais um número, que ele mesmo poderia paginar a revista; ao que Lina aprovou com 0 olhar e o fez assumir a direção durante 0 ano de 1951, com as publicações $n^{0} 10, n^{011}, n^{0} 12$ e $n^{0} 13$, edições que coincidem com o período que o casal esteve em viajem. Afirmou ser uma invenção sua fazer o número especial sobre as exposições da Pinacoteca do Masp na Europa, e haver uma grande quantidade de material pronto para ser publicado, o que o levou a apenas a preencher alguns vazios. Mas Lina, na volta da Europa e alterou a capa do próximo número - parte do material estava pronto para publicação, entre eles a capa que 0 próprio Flávio havia desenvolvido seguindo os princípios da proporção áurea - segundo uma referencia italiana. Disse ter ficado bastante desgostoso com este episódio, que neste momento ficou clara a diferença entre europeus e brasileiros. (silencio)

Sobre o nome de Lina e Pietro assinando os números 14 e 15, disse que se tratava de uma estratégia que admitia o prestígio com o qual o casal voltara da Europa e deu a entender que ele, Flávio Motta, manteve 0 mesmo papel que havia desempenhado nos três últimos números.

Pausa para um café e percebi que era momento de parar a conversa, o Professor e eu estávamos cansados. Haviam sido fornecidas muita informação, e Flávio Motta "garantiu" que poderíamos continuar num próximo dia.

\section{Notas:}

${ }^{1}$ Ver MORAIS, Fernando. Chatô, 0 Rei do Brasil. São Paulo, Editora Schwarcz Ltda, 1998, pg.476.

${ }^{2}$ Revista do Salão de Maio.

${ }^{3}$ Gente humilde (Garoto, Vinícius de Moraes, Chico Buarque e Nicanor). 
Conversa com Luís Hossaka

04 de março de 04 de março de 2006. No MASP.

Luís Hossaka inicia sua "relação" com o MASP em 1949, como ajudante de montagem de exposições. Freqüenta 0 curso do IAC e assim transforma-se em assistente de Pietro Maria Bardi.

Segundo Luís Hossaka, a revista Habitat era realizada dentro do Masp da Rua 7 de Abril, com a coordenação de Pietro Maria Bardi, Lina Bo Bardi e Flávio Motta. Hossaka relatou sua proximidade à produção da revista ao datilografar os textos, tarefa que Ihe conferia espaço para correções muitas vezes decorrente do "italianismo" presente e em alguns momentos, quando Bardi permitia, e inserção de algumas interferências próprias.

Quando questionado sobre a autoria dos artigos, Hossaka relatou que a revista era feita a "seis mãos", e que os demais colaboradores eram todos do círculo de amizade de Pietro e Lina Bo; que as pautas eram discutidas coletivamente pelos "Três" e que muitas vezes um interferia do texto do outro. Relatou também, que era habitual haver um "calhamaço" de textos prontos para as publicações.

Hossaka em nossa conversa discorreu longamente sobre sua relação com Lina Bo, sobre sua "capacidade" de descobrir talentos em jovens iniciantes, sobre seu olhar sobre o interior do país, o qual muitas vezes percorreu em sua companhia documentando por fotografias as viagens.

Quando questionado sobre a ausência do sul do país nas páginas da revista, comentou uma viajem que teria realizado para Porto Alegre com Lina em 1958, a fim de visitar um terreno que seria alvo de concurso para a sede da Assembléia Legislativa de Porta Alegre. Nesta viajem Lina teria ficado encantada com a população que conheceu e com uma "lamela" que encontrou pelo caminho. No entanto, arrisca que talvez por nessa região haver forte presença da imigração italiana e alemã, seu encantamento não foi avassalador como 0 que foi ao "desvendar" o interior do Brasil - com início em Governador Valadares, já em Minas Gerais.Sobre a quase totalidade de publicação de projetos de São Paulo, também arrisca que talvez a dificuldade de comunicação impedisse maior abrangência.

Comentei com Hossaka sobre o forte "peso" de Habitat dedicado ao MASP, o que prontamente rebateu: "era uma revista de divulgação do Museu".

Sobre 0 Expediente da revista nos primeiros anos, além da direção que cabia a Lina Bo, e em sua ausência a 
Flávio Motta, revelou que Geraldo Serra que aparece como Diretor Responsável no Expediente da revista seria um jornalista que fazia a "frente" da Gráfica O Papel, localizada na Rua Lavapés, cujo proprietário era Rodolfo Klein, que em Habitat aparece como editor. Rodolfo Klein, um estrangeiro, não poderia ser o proprietário de uma gráfica, sendo assim, essa "frente" era assumida por Geraldo Serra.

Quando questionado sobre o motivo da saída do casal Bardi da revista em 1954, Hossaka disse que "segundo sua opinião", o verdadeiro motivo seria a imposição por parte do editor de um novo projeto de editoração gráfica, o qual o casal recusa e se retira. Também levanta a possibilidade do fato de a revista ter um forte caráter crítico, e que essa critica não era sempre "bem recebida". 
M. Siegfried Giedion

Juin 15, 1948

7 Dortal

Zuerich

Cher Monsieur Giedion:

La guerre et les évenements que la suivent éloignent les hommes et rendent leurs rapports difficiles.

Je vous écris pour vous donner des nouvelles à moi. Je suis en Amérique, à

São Paulo, pour quelquer temps et j'ai organisé un musée que j'ai ensuite présenté au Congrès des Musées (ICOM), réuni par l'UNESCO àu Méxique.

Dans ce Musée, dont je vous envoie des photos, j'ai organisé des réunions vivants. Et je vou drais bien vous inviter pour donner un cours sur l'architecture moderne, selon un thème que vous pourriez choiser. Pourrez-vous me faire la gentilesse de me faire savoir quelles sont vos conditions? Quant à l'époque de ce cours, vous pourriez le faire vers la fin de l'na.

Je suis constammant au courant de ce que vous faites, par des publications et par les nouvelles que notre ami commun Rogers donne à propos dun CIAM. Je pense d'ailleurs que une votre visite au Brésil pourrait être très important pour le CIAM.

En attendant votre réponse, agréez l'ex pression de mon admiration.

P.M. Bardi, Directeur. 


\section{(papel timbrado do CIAM)}

les congrés internationaux d'architecture moderna

secretariat: Zurich 32, Doldertal 7, tel: 324644

\author{
JULY 5, 1948 \\ MR. P.M. BARDI, DIRECTOR \\ MUSEO DE ARTE \\ SÃO PAULO \\ RUA 7 DE ABRIL 216
}

DEAR MR. BARDI:

I WAS GLAD TO HEAR SUDDENLY FROM YOU FROM ANOTHER CORNER OF THE WORLD.

I ASKED SEVERAL PEOPLE ABOUT YOU, SINCE I HAD SEEN YOU IN 1938, BUT THEY COULDN'T GIVE ME ANY INFORMATION ABOUT YOU.

I'M VERY INTERESTED TO HEAR THAT YOU ARE ORGANIZING A MUSEUM IN SÃO PAULO. I'M SURE, CERTAINLY, IN A CONTEMPORARY SENSE. WE WOULD BE VERY INTERESTED IF WE COULD BE SENT ONE OF YOUR CATALOGS.

IN ANSWER TO YOUR LETTER OF JUNE 15, A FEW DAYS AFTER IT ARRIVED, I RECEIVED ONE FROM OSCAR NIEMEIR, IN RIO DE JANEIRO, PROPOSING ALSO A VISIT TO BRAZIL. I WOULD BE, OF COURSE, VERY MUCH INTERESTED ONCE TO SEE THIS PART OF THE WORLD. THE QUESTIONS ARE: DATE AND CONDITIONS. I WOULD PREFER, IF THERE IS THE POSSIBILITY, TO COME AT THE COLDEST TIME OF THE YEAR. THIS MENS, AS FAR AS I KNOW, JULLY TO SETEMBER, MAYBE YOU CAN GET IN CONTACT WITH NIEMAYER AND DISCUSS THE QUESTION WITH HIM. AND, AS IT AS, I JUST GOT NOTE FROM NA ARGENTINE PUBLISHER IN BUENOS AIRES THAT THEY WOULD LIKE TO PUT OUT A SPANISH EDITION OF MY BOOK, "SPACE, TIME AND ARCHITECTURE", SO THAT THESE DIFFERENTE THINGS COULD BE COMBINED.

I GUESS YOU ARE PERFECTLY RIGHT THAT THE CIAM COUL BE FURTHERED BY A TOUR THROUGH BRAZIL. WE ARE JUST PREPARING THERE THE JUBILEE PUBLICATION OF CIAM, AND I AM GIVING SPECIAL PLACE TO BRAZIL BECAUSE THERE IS NO COUNTRY WICH HAS PRODUCED DURING THE LAST TEM YEARS SUCH AN AMOUNT OF ENCOURAGING AND FORWARDLOOKING BUILDING ACTIVITY. WHAT WE LIKE ESPECIALLY IS THE KEENNESS OF APROACH, AND-IN CONTRAST TO OTHER AMERICAN COUNTRIES-THE GREAT SCALE AND MAGNITUDEOF THE SCHEMES.

PLEASE GIVE MY BEST REGARDS TO ROGERS. MANY THANKS FOR YOU KINDNESS IN REMENBERING ME.

VERY SINCERELY YOURS

S. GIEDION 
Deldertal, 7

\author{
Mr. Siegfried Giedion
}

Zuerich 32

Dear Mr. Giedion:

Thank you very much for your letter of july 5. I tried immediately to get in touch with Niemeyer, and went to Rio to see him, but unhappily he was travelling at the moment. But I left a letter, telling him of your visit to the Museu de Arte, and asking him to write me so that we could work out a program for you in order to unite both visits in one.

As soon as I get his answer, I shall let you Know and we could discuss the further details. In the meantime, I remain, with best wishes, Yours

P.M. Bardi. 
Mr. Siegfried Giedion

Deldertal, 7

December 7, 1948

Zuerich 32

Dear Mr. Giedion:

I was able only today to talk with Niemeyer about our idea of inviting you to Brazil. Niemeyer came to São Paulo in order to hold a lecture on Modern Architecture in Brazil, at our Museum: as matter of fact, this lecture had na estraordinari success.

We have decided two things: first os all to ask and to make the possible for you to be invited officially by the brazilian governement to come to this country and give two series of lectures, one at Rio de Janeiro and other at the "Museu de Arte de São Paulo". We have alredy given the first steps.

Secondly: we shall publish an important architecture magazine that shall be organized and oriented by Niemeyer, Eduardo Kneese de Mello, Lina Bo ( my wife, that has been director of "Domus" before Rogers, and os "A"), Gian Carlo Palanti ( that was a writer and organizer of "Construzioni"), Candido Portinari and by me.

For both things I shall write you soon again a more complete letter. In the meantime, I remain with best wishes.

\author{
Yours \\ P.M. Bardi.
}




\section{(Papel timbrado) URBANISTICA RIVISTA DELL'ISTITUTO NAZIONALE DI URBANISTICA CORSO VITTORIO EMANUELE, 75 \\ TORINO}

LA REDAZIONE

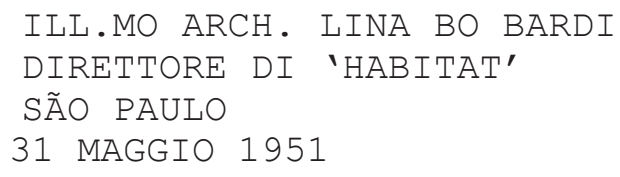

GENTILE SIGNORA LINA, PENSANDO DI FARE COSA UTILE ALLA SUA RIVISTA 'HABITAT', LE INVIO UMA SÉRIE DI FOTOGRAFIE RELATIVE ALLA SEZIONE DELL' URBANISTICA ALLA IX TRIENNALE DI MILLANO 1951.

ACCLUDO ALLE FOTO UM BREVE TEXTO INTRODUTTIVO ED ALCUNE DIDASCALIE CHE LEI POTRÀ MODIFICARE COMO MEGLIO RITERRÀ; INUTILE LE DICA CHE ALCUNE DELLA FOTO SI ALVANTAGGERANNO SE IMPAGINATE COM OPPORTUNI TAGLI. LA PREGO, NON APPENA LE SERÀ POSSIBLE DI VOLERMI SCRIVERE QUALCOSA IN MERITO.

DURANTE IL LAVORO ALLA TRIENALE EBBI MODO DI INTRATTENERMI COM CARLO PAGANI E DI RIEVOCARE ASSIEME LA BATTAGLIERA LINA BO.

GRAZIE, CORDIALE SALUTI.

(EGIDIO BANFANTE) 
Ilmo. Snr.

Roberto Burle Marx

R. General Rezende Costa, 4

Rio de Janeiro

D.F.

Caro Roberto,

Acabo de receber uma carta de meu marido, na qual ele diz que da sua exposição, fala-se mais na Europa que na América, e que (depois dos Estados Unidos), o Kunstgeneral museum de Zurich esta pedindo a exposição; eles farão um catálogo especial; meu marido irá a Zurich, especialmente para combinar.

$\dot{E}$

estritamente necessário fotografar todos os painéis, sendo que dos melhores farei a apresentação em duas páginas a mais, no próximo Habitat (juntamente com as outras coisa suas). Precisarei ir ao Rio (no dia 12 à noite, chegarei), peço-lhe portanto aprontar as fotografias da exposição, a fotografia do sei sítio (para os desenhos), as suas notas sobre o mesmo, e coisa importante: combinar a reportagem com o fotógrafo Marcel Gautherot. Poderia ser sábado 13 e domingo 14? Peço-lhe o favor de telegrafar-me a resposta, aqui para o Museu. (via Western, pois os telegramas comuns nunca chegam).

antecipado da sua exposição.

Estou feliz pelo sucesso 
Sobre a "Forma na Arquitetura" de Oscar Niemeyer

A atuação de Niemeyer é 'política', mesmo no caso da arquitetura. Atuação dentro de uma realidade ao contrário do que se parece 'à priori'. O que nele permanece profundo, apesar das afirmações em contrário, é a lição racionalista aprendida nos anos 130 (anos de uma formação profissional) no convívio fundamental com Le Corbusier.

A experiência Racionalista permitiu a Oscar Niemeyer, o uso das Formas livres lúcidas (isto é dentro e um certo vigor), o que não teria acontecido se sua formação tivesse derivado de uma experiência "Beaux Arts" (definição ao 'limite'), como ameaça ser a Liberdade de muitas correntes artísticas de hoje; volta, num certo sentido ao passado.

A Liberdade Formal de Oscar Niemeyer tem sempre um fundo daquilo que Pasolini definiu com Semiótica da Realidade, isto é, o contrário do Formalismo.

Conheci Oscar Niemeyer em '46 no IAB do Rio. De terno Lilás (inédito por alguém que chegava da Europa). Seu ar ledo e manso, profundamente melancólico, escondia uma vontade de ferro de 'fazer', e fazer para os outros. Nas andanças pela velha Lapa, pelo velho Rio, com os 'velhos amigos' à procura de uma tipografia que pudesse imprimir uma revista de Arquitetura, ponte Rio - São Paulo (como estávamos projetando), repetia: "você chega da Europa, você complica demais". E o veredicto final dele e dos 'velhos Amigos': "Esta aliança Rio - São Paulo não tem sentido, cada um vae ficar no seu lugar". Assim nasceram duas revistas: Habitat, feita por nós em São Paulo ( documento de Cultura Brasileira, mesmo no seu português de importação), e Módulo, feita por eles no Rio, (importante e primeiro esforço de revista de Arquitetura no Brasil). o conceito de Forma, por Oscar, é ainda ligado a tradição das culturas que consideram a Arte como conhecimento, ao contrário da Teoria da Comunicação, que considera também a Arte como conjunto de Signos isto é de mensagens a serem decodificadas. Mais o uso do conceito de Forma é devido a estreita ligação que ele sente entre função estética e dever social, ligação sentida generosamente, sem mesquinhas ligações intelectuais.

Só uma ressalva dedicada as novas gerações.

Tudo isso aconteceu num tempo terrível e precioso: tempo de vidas cortadas, de sobrevivência dura, de intervenções e morte. É uma grande herança cultural. Mas é inútil chorar sobre as contingências históricas. Tudo isto passou. Mesmo se fica.

Ao arquiteto de hoje seja talvez reservada uma tarefa quase anônima, de participação direta. Como os grandes construtores de Catedrais, riscar na areia dos canteiros os mínimos detalhes (mesmo se controlados por Computers), acompanhando em silêncio a realização dum Serviço Coletivo.

Lina Bo Bardi S.P. $9-7-^{\prime} 78$ 


\section{Trecho da carta enviada por Lina a Portinari.}

28 de setembro de 1948

"(...) RIGUARDO ALLA RIVISTA LE COMUNiCO LE SEGUINTI COSI CHE LEI PER FAVORE DIRÀ ANCHE A OSCAR NIEMAJIER:

ABBIAMO PARLATO COM KNEESE DE MELLO; CHE HA ACCETTATO DI FAR PARTE DEL COMITATO DIRETTIVO PER L'ARCHITETTURA (COME D'ACOORDO).

LA CARTA DA LETTERE DELLA REVISTA È GIÀ IN TIPOGRAFIA COM I DUE INDIRIZZI DI RIO E SAN PAOLO; E MOLTO SEMPLÍCE; APPENA PRONTA LA MANDERÒ.

HO TELEGRAFO A MARCOS PERCHE OCCO PRONO DI URGENZA LE PIANTE E QUALCHE FOTOGRAFIA IN NERO DEL BANCO BOA VISTA; OCCORRONO PER LE QUATTRO PAGINE PUBBLICITARIE CHE BISOGNA PREPARARE SUBITO. VEDA PER FAVORE DI SOLLECITARE LEI, NIEMAJER.

LA REVISTA RESTA COSTITUITA CÒSI

COMITATO DIRETTIVO: ARCHITETTI, OSCAR NIEMAJIER, EDUARDO KNEESE DE MELLO, GIANCARLO PALANTI, CANDIDO PORTINARI E PIETRO BARDI. POICI SARÀ MARCOS CHE CURERÀ LA REDAZIONE E IL MATERIALE A RIO E IO ORGANIZZERÒ LA RIVISTA.

APPENA PRONTI I FLOGI DI IMPAGINAZIONE E LA CARTA DA LETTERE LI MANDEREMO. DOMANI MANDAREMO LE LETTERE DI RECIPROCO AMICHEVOLE IMPEGNO.

STO MULTO LAVORANDO PER SORMONTARE LE DIFFICOTÀ.

IL CATALOGO DELLA SUA ESPASIZIONE VIENE BENE; MIO MARITO LE DIRÀ POI QUANDO MANDARE I QUADRO; IN OGNI MODO LA SUA VENUTA RESTA FISSATA PER IL 28 OTTOBRE ASSIEME A NIEMAJER, QUESTO E IMPORTANTE ANCHE AGLI EFFETTI DELLA PIVISTA.

MOLTI CORDIALI SALUTI A SUA MOGLIE, MOLTI SALUTI A VEI, NIEMAJER E MARCOS . 
